\title{
CRITÉRIOS PARA A GESTÃO DE ÁREAS SUSPEITAS OU CONTAMINADAS POR RESÍDUOS SÓLIDOS - ESTUDO DE CASO NA REGIÃO METROPOLITANA DE SÃO PAULO
}

\author{
SEIJU HASSUDA
}

Orientador: Prof. Dr. Aldo da Cunha Rebouças

TESE DE DOUTORAMENTO

COMISSÃO JULGADORA

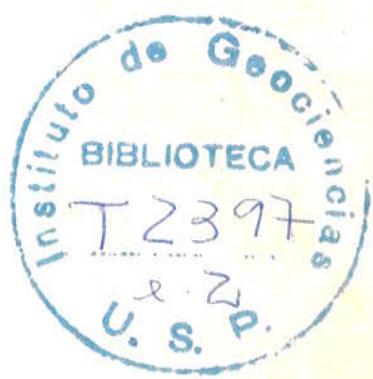

Nome

Assinatura

Presidente: Prof. Dr. Aldo da Cunha Rebouças

Examinadores: Prof. Dr. Aujelbani Bráz da Silva

Prof. Dr. José Milton Benetti Mendes

Prof. Dr. Luiz Roberto Cottas

Prof. Dr. Samuel Murgel Branco

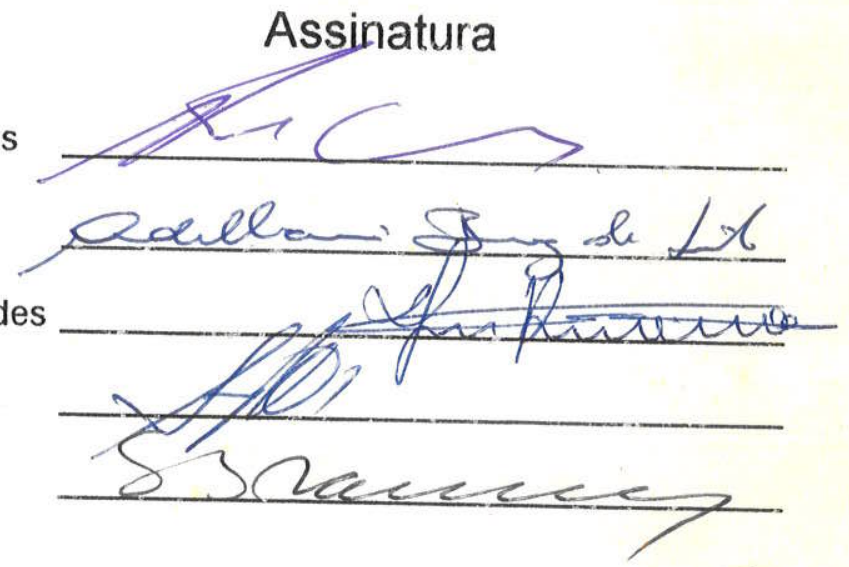

SÃO PAULO 


\section{UNIVERSIDADE DE SĀO PAULO INSTITUTO DE GEOCIENCIAS}

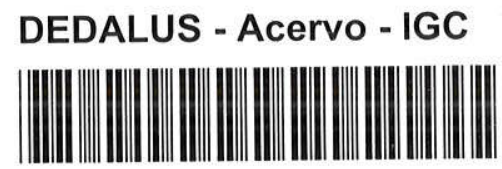

30900005051

\section{CRITÉRIOS PARA A GESTÃO DE ÁREAS SUSPEITAS OU CONTAMINADAS POR RESÍDUOS SÓLIDOS - ESTUDO DE CASO NA REGIÃO METROPOLITANA DE SÃO PAULO}

Seiju Hassuda

Orientador: Prof. Dr.Aldo da Cunha Rebouças

TESE DE DOUTORAMENTO

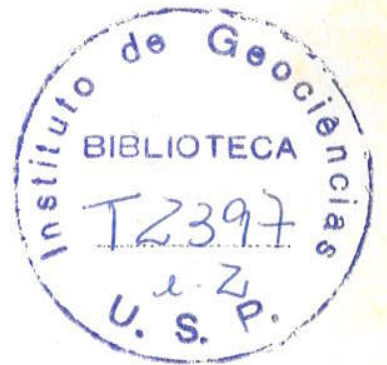

Área de Concentraçãc: Recursos Minerais e Hidrogeologia 


\section{AGRADECIMENTOS}

O autor gostaria de expressar a sua gratidão pela ajuda e incentivos recebidos durante o desenvolvimento da tese para as seguintes pessoas:

Ao Prof. Dr. Aldo da Cunha Rebouças e Eng. Agron. Rodrigo César de Araújo Cunha, da CETESB, pelas discussões, leituras e sugestões.

À Geól. Márcia Pressinotti, diretora do Instituto Geológico, pelo seu apoio pessoal e institucional.

Ao Dr. Andreas Marker e Eng. Marco Antonio Gunther por permitir a utilização das informações do Cadastro de Áreas Contaminadas.

Aos colegas Mara Akie Iritani e Paulo César Fernandes pela revisão do texto e valiosas sugestões realizadas.

Ao Geól. Alexandre Magno de Sousa Maximiano pelo auxílio nos trabalhos de digitalização dos mapas e edição final do trabalho.

Aos colegas Elton Gloeden, Wagner França Aquino, Vicente de Aquino Neto, Nádia Azevedo de Almeida, Álvaro Gutierrez Lopez, Maria José de Barros Fraccaroli pelos trabalhos de campo realizados em conjunto.

Aos geólogos Geraldo Hideo Oda, Ricardo César Aoki Hirata e Sueli Yoshinaga e, à Geógrafa Luciana Rodrigues Martin Ferreira pelo incentivo em todos os momentos do trabalho. 


\section{SUMÁRIO}

LISTA DE ANEXOS

LISTA DE FIGURAS v v

LISTA DA QUADROS vii

LISTA DE TABELAS $\quad$ ix

RESUMO $\quad x$

ABSTRACT

1. INTRODUÇÃO 1

2. OBJETTVOS DA TESE 2

3. PROBLEMÁTICA MUNDIAL SOBRE DESTINO FINAL DE RESÍDUOS SÓLIDOS

PARTE 1. FUNDAMENTOS E ESTRATÉGIAS DE GESTÃO DE ÁREAS CONTAMINADAS

4. TÉCNICAS E MÉTODOS EXISTENTES DE GESTÃO DE ÁREAS CONTAMINADAS

4.1. Experiência na Alemanha 11

4.2. Experiência do Canadá 13

4.3. Experiência nos E.U.A $\quad 14$

4.4. Experiência no Brasil 16

5. MODELO DE GESTÃO DE ÁREAS CONTAMINADAS $\begin{array}{ll}\text { ELABORADA PARA RMSP } & 17\end{array}$

5.1. Conceituação Técnico-Científica 19

5.2. Sistema de Gerenciamento de Áreas Contaminadas 21

5.2.1. Definição da região de interesse e dos bens a proteger $\quad 21$

5.2.2. Áreas Potenciais (APs) 24

5.2.3. Áreas Suspeitas (ASs) 29

5.2.4. Áreas Contaminadas (Acs) 31

5.2.5. Caracterização de Acs 33

5.2.6. Plano de Remediação de Áreas Contaminadas 33

5.3. Infraestrutura do Sistema de Gerenciamento de Áreas

5.3.1. Cadastro Informatizado $\quad 34$

5.3.2. Cadastro Físico $\quad 35$ 
6. GESTÃO DE ÁREAS DE DISPOSIÇÃO DE RESÍDUOS SÓLIDOS PARA RMSP

6.1. Priorização de Áreas Potenciais $\quad 36$

6.2. Avaliação Preliminar $\quad 37$

6.2.1. Ficha Cadastral e de Pontuação de Áreas 37

$\begin{array}{ll}\text { Contaminadas } & 37 \\ & 61\end{array}$

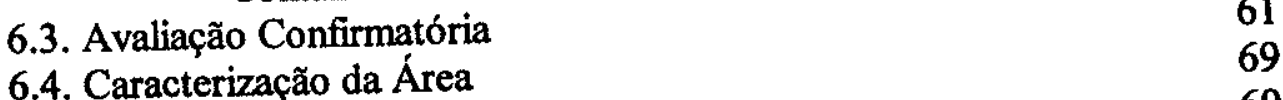

$\begin{array}{ll}\text { 6.4. Caracterização da Área } & 69 \\ \text { 6.5. Recuperação da Área } & 69\end{array}$

PARTE 2. ESTUDOS DE CASOS NA REGIÃO METROPOLITANA DE SÃo PaUlO

7. AVALIAÇÃo REGIONAL: Região Metropolitana de São Paulo (RMSP)

7.1. Aspectos sócio-econômicos

7.2. Diagnóstico dos Recursos Hídricos na RMSP

7.2.1. Águas Superficiais $\quad 75$

7.2.1.1. Quantidade 77

7.2.1.2. Qualidade 77

7.2.2. Águas subterrâneas $\quad 82$

7.2.2.1. Quantidade $\quad 82$

7.2.2.2. Qualidade $\quad 85$

7.3. Diagnóstico das áreas de disposição de resíduos 85

7.3.1. Produção de resíduo sólido doméstico 85

7.3.2. Localização das áreas de disposição 86

7.3.3. Morfologia do terreno e ocupação no local $\begin{array}{ll}\text { de disposição e áreas adjacentes } & 88 \\ & 90\end{array}$

$\begin{array}{ll}\text { 7.3.4. Local de disposição e o contexto hidrogeológico } & 90 \\ 7.3 .5 \text { Aspectos construtivos dos locais de disposição } & 93\end{array}$

\begin{tabular}{ll} 
7.3.5. Aspectos construtivos dos locais de disposição & 93 \\
\hline
\end{tabular}

$\begin{array}{cc}\text { 7.4. Sistema de classificação dos locais de disposição } & 96 \\ \text { 7.4.1. Preenchimento da Ficha de Pontuação } & 96\end{array}$

7.4.2. Distribuição espacial dos locais de disposição por $\quad 97$ pontuação $\quad 111$

$\begin{array}{ll}\text { 7.4.3. Classificação das áreas de disposição } & 111 \\ \text { 7.4.4. Priorização das áreas de disposição } & 113\end{array}$

8. AVALIAÇÃO LOCAL: LIXÃO DO ALVARENGA 115

8.1. Localização 115

8.2. Descrição da área do lixão e adjacências $\quad 120$

$\begin{array}{ll}\text { 8.3. Avaliação Preliminar } & 120\end{array}$

8.3.1. Diagnóstico da área de disposição 120

8.3.2. Preenchimento da Ficha de Pontuação 125

8.3.2.1. Características da fonte de contaminação $\quad 125$

8.3.2.2. Meios de propagação

127 
8.3.2.3. Bens a Proteger

8.3.3. Resultado da Pontuação

8.4. Avaliação Confirmatória

8.4.1. Levantamento Geofísico

8.4.2. Resultados das análises químicas das cacimbas

9. CONSIDERAÇÕES FINAIS

10. CONCLUSÕES

11. BIBLIOGRAFIA
137 


\section{LISTA DE ANEXOS}

Anexo 1. Ficha Cadastral e Ficha de Pontuação

Anexo 2. Pontuações obtidas pelas áreas de disposição de resíduos da RMSP 


\section{LISTA DE FIGURAS}

Figura 1. Sistema para avaliação do índice de vulnerabilidade do aquífero

(FOSTER \& HIRATA 1988)

Figura 2. Fluxograma de gerenciamento de áreas contaminadas

Figura 3. Evolução da concentração dos gases $\mathrm{CH}_{4}, \mathrm{CO}_{2}, \mathrm{NO}_{2}, \mathrm{O}_{2}$ e $\mathrm{H}_{2}$

Figura 4. Mapa e quadro demonstrando a distribuição da população por municípios da RMSP

Figura 5. Mapa e quadro demonstrando a distribuição da densidade demográfica por municípios da RMSP

Figura 6. Municípios atendidos pela SABESP e serviços autônomos municipais (SABESP, 1994)

Figura 7. Mapa com sistemas adutores da RMSP (modificado de SABESP, 1994)

Figura 8. Mapa de qualidade das águas superficiais da RMSP (Modificado de CETESB, 1992)

Figura 9. Mapa com localização das áreas de disposição de resíduos sólidos da RMSP (CETESB, 1997)

Figura 10. Gráfico e quadro demonstrando a distância das edificações em relação aos locais de disposição

Figura 11. Gráfico e quadro demonstrando a existência de catadores nos locais de disposição

Figura 12. Quadro resumo ilustrativo do contexto hidrogeológico da RMSP associados ao número de locais de disposição de resíduos

Figura 13. Aspectos construtivos dos locais de disposição dos resíduos sólidos (modificado de IPT, 1995)

Figura 14. Mapa de pontuação das áreas de disposição considerando BP1 - Saúde e vida da população

Figura 15. Mapa de pontuação das áreas de disposição considerando BP2 Abastecimento público

Figura 16. Mapa de pontuação das áreas de disposição considerando BP3 - Uso do solo 
Figura 17. Mapa de pontuação das áreas de disposição considerando BP4 Proteção das águas subterrâneas e superficiais

Figura 18. Mapa de pontuação das áreas de disposição considerando BP5 - Uso agrícola e pecuária

Figura 19. Mapa de pontuação das áreas de disposição considerando BP6 - Outros bens a proteger

Figura 20. Mapa com valores estatísticos de BP1 por município

Figura 21. Mapa com valores estatísticos de BP2 por município

Figura 22. Mapa com valores estatísticos de BP3 por município

Figura 23. Mapa com valores estatísticos de BP4 por município

Figura 24. Mapa com valores estatísticos de BP5 por município

Figura 25. Mapa com valores estatísticos de BP6 por município

Figura 26. Figura demonstrando a distribuição do número de áreas por faixa de pontuação para BP1, BP2 e BP3

Figura 27. Figura demonstrando a distribuição do número de áreas por faixa de pontuação para BP4, BP5 e BP6

Figura 28. Localização do Lixão do Alvarenga

Figura 29. Ilustração fotográfica dos três Lixões de Alvarenga

Figura 30. Ilustração fotográfica de alguns tipos de resíduos encontrados no Lixão de Alvarenga

Figura 31. Ilustração fotográfica de catadores e animais na área do Lixão de Alvarenga

Figura 32. llustração fotográfica do escoamento do chorume para a Represa Billings

Figura 33. Mapa de isovalores de condutividade elétrica na área do Lixão do Alvarenga

Figura 34. Mapa de isoconcentração de sódio das águas subterrâneas provenientes das cacimbas na área do Lixão de Alvarenga 


\section{LISTA DE QUADROS}

Quadro 1. Exemplo de cadeia de eventos da fonte para o receptor (CCME,1992)

Quadro 2. Níveis de escalas de trabalho (modificado de HIRATA, 1994)

Quadro 3. Meios a serem investigados e tipos de investigação a serem executados.

Quadro 4. Quadro contendo informações sobre Identificação da Área

Quadro 5. Quadro com informações sobre a forma de disposição de resíduos

Quadro 6. Quadro com informações sobre descrição da área disposição de resíduos e de áreas adjacentes

Quadro 7. Quadro com informações sobre eventos importantes ocorridos na área de disposição de resíduos

Quadro 8. Quadro resumo sobre atividades de gerenciamento de áreas de disposição de resíduos sólidos a serem desenvolvidas

Quadro 9. Quadro resumo sobre etapas do Sistema de Pontuação

Quadro 10. Valores de Rn e Mn para o componente $R a_{l}$

Quadro 11. Valores de Rn e Mn para o componente $R a_{2}$

Quadro 12. Valores de Rn e Mn para o componente $R b_{1}$

Quadro 13. Valores de Rn e Mn para o componente $R b_{2}$

Quadro 14. Valores de Rn e Mn para o componente $R b_{3}$

Quadro 15. Valores de Rn e Mn para o componente $R b_{4}$

Quadro 16. Valores de Rn e Mn para o componente $R c$

Quadro 17. Totalização do sistema de pontuação

Quadro 18. Resumo do consumo, demanda média e índices de perdas no sistema de abastecimento da RMSP (SABESP, 1995)

Quadro 19 - Parâmetros analisados na rede de monitoramento da CETESB (CETESB, 1992)

Quadro 20. Índice de qualidade da água na RMSP (CETESB, 1992)

Quadro 21. Potencialidade e disponibilidade de água subterrâna na RMSP (CEPAS, 1994) 
Quadro 22. Número de áreas de disposição por intervalo para os bens a proteger (BP1 a BP6) 


\section{LISTA DE TABELAS}

Tabela 1. População e área de vários países da Terra

Tabela 2. Produção total e geração per capita de resíduos de vários países

Tabela 3. Composição de resíduo doméstico (\%)

Tabela 4. Destino final de resíduo doméstico (\%)

Tabela 5. Composição química de lixiviado de aterros da RMSP (CETESB, 1993)

Tabela 6. Variação da concentração dos constituintes do lixiviado em função do tempo

Tabela 7. Tabela com substâncias possiveis de serem encontrados nos lixiviados nos locais de disposição de resíduos sólidos (EPA, 1994).

Tabela 8 - Valores referenciais da Holanda para solo e água subterrânea (VROM, 1994)

Tabela 9. Tabela com massa de lixo por município da RMSP

Tabela 10. Morfologia do terreno nas áreas de disposição

Tabela 11. Áreas críticas de disposição de resíduos para o BP1

Tabela 12. Áreas críticas de disposição de resíduos para o BP2

Tabela 13. Áreas críticas de disposição de resíduos para o BP3

Tabela 14. Áreas críticas de disposição de resíduos para o BP4

Tabela 15. Áreas críticas de disposição de resíduos para o BP5

Tabela 16. Áreas críticas de disposição de resíduos para BP1 a BP6 (com pontuação acima de 300)

Tabela17. Pontuação Lixão de Alvarenga

Tabela 18. Características químicas e bacteriológicas das cacimbas em Alvarenga 


\section{RESUMO}

Este trabalho teve como objetivo principal estabelecer critérios para a gestão de áreas de disposição de resíduos sólidos. Ele visou também fornecer à comunidade técnico-científica um método de estudo e pesquisa dirigida à questão de áreas suspeitas e contaminadas por resíduos sólidos.

$\mathrm{O}$ texto encontra-se dividido em duas partes, na primeira, apresenta-se o modelo e a metodologia tanto para a avaliação de áreas contaminadas como para os locais de disposição de resíduos sólidos. $\mathrm{Na}$ segunda parte, as metodologias estão aplicadas para a Região Metropolitana de São Paulo (RMSP), ao nível regional, e ao Lixão de Alvarenga, ao nivel local.

Os trabalhos na RMSP permitiram definir áreas críticas nos locais de disposição de resíduos sólidos onde os seguintes elementos encontram em risco: 28 áreas em relação à saúde e vida da população (BP1), 8 para o abastecimento público (BP2), 4 para uso do solo (BP3), 8 para a proteção das águas superficiais e subterrâneas (BP4) e 5 para áreas de produção agropecuária (BP6).

Entre as 116 áreas de disposição de resíduos da RMSP, o Lixão de Alvarenga foi a que se apresentou mais crítica em relação aos vários aspectos. Os catadores e a população que reside sobre o lixão e/ou nas adjacências convivem diretamente com problemas dermatológicos e doenças de veiculação hídrica. Nas adjacências do local, a jusante, várias residências utilizam água subterrânea proveniente de cacimbas. $O$ lixiviado escoa diretamente para a Represa Billings que é um manancial que abastece algumas cidades da RMSP. Na área, a difusão de gases é um problema comum inclusive com registro de explosão no passado.

Com os estudos realizados definiram-se basicamente duas linhas de ação, a primeira, visando a preservação da saúde e vida da população que residem no local e nas adjacências dos locais de disposição e, a segunda, objetivando a proteção dos recursos naturais da RMSP. 


\section{ABSTRACT}

The main objective of this thesis is to establish criteria for management of solid waste disposal areas. It also aimed to provide the technical-scientific community with a method of study and research directed to the issue of suspect and contaminated areas by solid waste.

The text is divided in two parts: in the first, the model and methodology to evaluate not only contaminated areas but also sites of solid waste disposal are presented. In the second part, the methodologies are applied at a regional level to the Metropolitan Region of São Paulo (RMSP), and at a local level to the Alvarenga Landfill.

The works in the RMSP allowed to define critical areas in the sites of solid waste disposal where the following elements are at risk: in 28 areas, the health and life of the population (BP1); in 8, public water supply (BP2); in 4, land use (BP3); in 8, protection of superficial and ground waters (BP4), and in 5, the areas of farming production (BP6).

Among the 116 solid waste disposal areas in the RMSP, the Alvarenga Landfill was the most critical regarding various aspects. The pickers and the population of the landfill and/or surroundings live directly with skin problems and diseases transmitted through water. Nearby and downstream, several dwellings use groundwater from shallow wells (cacimbas). Leachate flows directly to the Billings Dam, which supplies water to some cities of the RMSP. In the area, the diffusion of gases is a usual problem, including records of explosions.

With the studies, basically two lines of action were defined: the first, aiming the preservation of the health and life of the population living in the disposal areas or nearby, and second, the protection of natural resources in the RMSP. 


\section{INTRODUÇÃO}

A vida humana encontra-se presente sobre a face da Terra há millões de anos numa complexa relação entre meio físico e biótico. No último século com o advento da revolução industrial, o ser humano tem manipulado milhares de substâncias, naturais ou sintéticas, muitas vêzes de forma inadequada, trazendo danos significativos ao meio ambiente e à própria qualidade de vida.

Nos países desenvolvidos, as ações preventivas e corretivas vem sendo tomadas isoladamente há mais de 30 anos em relação à degradação do meio ambiente. Por outro lado, nos países em desenvolvimento em função da falta de recursos financeiros pouco tem sido feito para conservar e preservar o meio ambiente.

$\mathrm{Na}$ "Conferência das Nações Unidas Sobre o Meio Ambiente e Desenvolvimento-ECO 92", realizada no Rio de Janeiro, em 1992, foi traçada uma estratégia internacional conjunta, onde a tese básica definida foi a de que os recursos naturais devem ser a base do desenvolvimento econômico e que, portanto, a proteção ambiental e o desenvolvimento econômico devem ser considerados em conjunto (ANDRADE, 1996). Por outro lado, no evento realizado em março deste ano, denominado RIO+5, chegou-se a conclusão de que os paises que participaram na ECO92 não conseguiram cumprir grande parte das metas previstas no acordo traçado há cinco anos atrás.

Levando em consideração o contexto acima mencionado, o intuito desta tese é apresentar critérios para a gestão de áreas de disposição de resíduos sólidos. Este por sua vez faz parte de um modelo mais abrangente de gestão de áreas contaminadas.

Os resíduos sólidos domésticos tem despertado discussão e polêmica tanto no meio técnico-científico, nas universidades e instituições de pesquisa, quanto nos órgãos públicos responsáveis pela regulamentação e controle, não havendo consenso entre as partes envolvidas e/ou interessadas. Os esforços têm sido concentrados na situação atual cuja problemática reside na adequação do local onde os resíduos devem ser dispostos e qual a melhor maneira de fazê-lo do ponto de vista ambiental. Todavia a questão das áreas já existentes, desativadas ou não, que 
muitas vêzes foram mal construídas ou operadas, tem sido pouco abordada havendo uma carência de propostas sobre a destinação a ser dada para tais áreas.

$O$ presente trabalho divide-se em 3 tópicos principais: modelo de gestão de áreas contaminadas para RMSP; metodologia de gestão de áreas de disposição de resíduos sólidos para RMSP; aplicação da metodologia de gestão de áreas de disposição de resíduos sólidos para RMSP e um estudo de caso.

\section{OBJETIVOS DA TESE}

O objetivo principal desta tese é apresentar critérios para a gestão das áreas suspeitas ou confirmadas de contaminação por disposição de resíduos sólidos. Dentro deste escopo, realizou-se um diagnóstico das áreas de disposição de resíduos sólidos na RMSP com propostas de prioridade de medidas e ações para proteger os recursos naturais e a saúde pública.

Outro objetivo específico, é fornecer à comunidade técnico-científica um método de estudo e pesquisa dirigida à questão de áreas suspeitas e contaminadas por resíduos sólidos.

\section{PROBLEMÁTICA MUNDIAL SOBRE DESTINO FINAL DE RESÍDUOS SÓLIDOS}

A geração de resíduos sólidos domésticos tem crescido numa relação diretamente proporcional ao crescimento da população mundial. Associado a isso, a mudança dos hábitos de consumo da sociedade atual tem conduzido à geração de produtos descartáveis e de bens com curto tempo de vida útil. como decorrência, a natureza e a quantidade de resíduo doméstico tem mudado drásticamente nas últimas décadas.

Acrescentando o fato de que a migração da população de zonas rurais para áreas urbanas também tem contribuído para o aumento da geração de lixo nas cidades. Considerando 11 países europeus, 2 países da América do Norte e da América do Sul, da Ásia e da África (1 país de cada continente), observa-se uma variação na densidade demográfica de 2,6 habitantes $/ \mathrm{km}^{2}$ no Canadá 
para 1452 habitantes $/ \mathrm{km}^{2}$ no Japão (MITI, 1994). Nestes países, a percentagem da população habitando em áreas urbanas varia de um mínimo de 50\% até um máximo de 88\% (TABELA 1).

Até o início da década de 70, um cidadão comum preocupava-se com o lixo até o momento em que o caminhão de coleta o removia de sua residência. Em vários países esta visão tem se modificado. Muitas pessoas tem questionado o destino e os efeitos que o lixo pode causar ao meio ambiente.

Na década de 80 , muitas entidades de pesquisa e controle ambiental produziram relatórios e publicações científicas sobre efeitos a curto e longo prazo, causados pela prática de disposição de resíduos no solo efetuada no passado (BROWNELL et al, 1982; BULL et al, 1983; CUMINS, 1981; GRAHAM, 1981; POHLAND, 1980). Atualmente, o assunto "disposição de resíduos sólidos" tem despertado interesse político em todas as esferas do poder quais sejam, municipal, estadual, internacional, além de interesse científico e da preocupação social.

Nos últimos 10 a 15 anos em muitos países desenvolvidos, uma legislação referente à disposição de resíduos sólidos tem se desenvolvido e profissionais da área ambiental têm contribuido com a elaboração de padrões e normas (CETESB, prelo). Em alguns países, a legislação tem requerido um planejamento do gerenciamento da disposição dos resíduos sólidos.

A tabela 2 apresenta a produção anual e a geração per capita de resíduo doméstico nos paises apresentados na tabela anterior. De uma forma genérica, observa-se que, quanto mais desenvolvido economicamente o país, maior é a geração per capita. $O$ valor médio obtido situa-se em torno de $1 \mathrm{~kg} /$ pessoa/dia e a população do Brasil apresenta um valor menor que 0,6 $\mathrm{kg} / \mathrm{pessoa} / \mathrm{dia}$.

A tabela 3 mostra a composição de resíduo doméstico de vários países. Nela observa-se que as categorias de papel e de matéria orgânica somam a maior parte da composição do resíduo doméstico na maioria dos países. A média da somatória é de $63,77 \%$, portanto juntas representam mais da metade da composição total do resíduo. Além destes, vidros, plásticos e metais possuem uma importância secundária na composição do resíduo.

Na composição do resíduo doméstico do Brasil a matéria orgânica sozinha possui valor de $64,4 \%$, enquanto que a média é de $33,2 \%$, portanto um valor bastante superior aos dos outros países. 
Tabela 1. População e área de vários países da Terra

\begin{tabular}{l|r|r|r|c}
\hline \multicolumn{1}{c|}{ País } & $\begin{array}{c}\text { Área } \\
\left(\mathbf{K m}^{2}\right)\end{array}$ & $\begin{array}{c}\text { Pop. } \\
\text { (milhão) }\end{array}$ & $\begin{array}{c}\text { Dens. } \\
\text { Demog. } \\
\left.\text { (pessoa/km }{ }^{2}\right)\end{array}$ & $\begin{array}{c}\text { Ocupação } \\
\text { Urbana(\%) }\end{array}$ \\
\hline Austria & 83.855 & 7.9 & 94,2 & 55 \\
\hline Canadá & 9.855 .000 & 25.4 & 2,2 & 76 \\
\hline Dinamarca & 43.000 & 5.1 & 118,6 & 83 \\
\hline Finiândia & 338.000 & 4.9 & 14,5 & 60 \\
\hline França & 550.000 & 54.3 & 98,7 & 75 \\
\hline Alemanha & 250.000 & 61.0 & 235,0 & - \\
\hline Itália & 301.260 & 56.2 & 186,5 & - \\
\hline Japão & 378.000 & 120.0 & 1452,0 & 76 \\
\hline Holanda & 41.473 & 14.5 & 349,6 & 88 \\
\hline Polônia & 312.683 & 36.9 & 118,0 & 57 \\
\hline Africa do sul & 1.116 .000 & 31.9 & 28,6 & 48 \\
\hline Suécia & 450.000 & 8.4 & 18.7 & 83 \\
\hline Suíça & 41.293 & 6.5 & 157,4 & 51 \\
\hline Gră-Bretanha & 241.200 & 56.0 & 232,2 & 70 \\
\hline USA & 9.275 .955 & 235.0 & 25,3 & 79 \\
\hline Brasil & 8.511 .965 & 146.9 & 17,3 & 75 \\
\hline
\end{tabular}

Fonte: Modificado de IBGE (1992) 
Tabela 2. Produção total e geração per capita de resíduos de vários paises

\begin{tabular}{l|r|r}
\hline \multicolumn{1}{c|}{ País } & \multicolumn{1}{c|}{$\begin{array}{c}\text { Total } \\
\left(10^{8} \text { t/ano }\right)\end{array}$} & $\begin{array}{c}\text { Per Capita } \\
\text { (kg/pessoa/dia })\end{array}$ \\
\hline Austria & 1,7 & 0,6 \\
\hline Canadá & 25,0 & 2,7 \\
\hline Dinamarca & $1,3-3,4$ & $0,7-1,8$ \\
\hline Finlândia & $2,0-3,0$ & $0,5-1,6$ \\
\hline França & $17,8-49,8$ & $0,9-2,5$ \\
\hline Alemanha & 24,0 & 1,1 \\
\hline Itália & 17,3 & 0,8 \\
\hline Japåo & 41,0 & $0,9-1,1$ \\
\hline Holanda & 8,5 & 1,6 \\
\hline Polônia & - & $0,6-1,3$ \\
\hline Africa do sul & 12,0 & 1,0 \\
\hline Suécia & 2,5 & 0,8 \\
\hline Suíça & 6,3 & 2,6 \\
\hline Gră-Bretanha & 18,0 & 0,9 \\
\hline USA & 72,0 & 1,6 \\
\hline Brasil & 32,9 & 0,6 \\
\hline Fon
\end{tabular}

Fonte: Carra, et al (1990) e IPT(1994) 
Tabela 3. Composição de residuo doméstico (\%)

\begin{tabular}{l|r|r|r|r|r|r|r|r}
\hline País & Papel & Orgân. & Vidros & Plast. & Metais & Têxteis & $\begin{array}{r}\text { Mat. } \\
\text { Const }\end{array}$ & Outros \\
\hline Austria & 22,4 & 27,8 & 5,3 & 10,3 & 4,2 & 2,2 & 4,6 & 23,2 \\
\hline Canadá & 38,9 & 33,9 & 6,5 & 4,9 & 6,2 & 3,6 & 1,8 & 4,4 \\
\hline Dinam. & 29,0 & 28,0 & 4,0 & 5,0 & 13,0 & - & - & 21,0 \\
\hline Finiand. & 51,0 & 29,0 & 6,0 & 5,0 & 2,0 & 2,0 & - & 5,0 \\
\hline França & 30,0 & 25,0 & 12,0 & 6,0 & 5,0 & 4,0 & - & 18,0 \\
\hline Alema. & 20,8 & 28,3 & 10,4 & 7,7 & 3,9 & - & 2,8 & 26,1 \\
\hline Itália & 22,3 & 42,1 & 7,1 & 7,2 & 3,0 & - & - & 18,3 \\
\hline Japão & $31-37$ & $10-16$ & $14-16$ & $14-16$ & $5,5-6,4$ & 3,8 & - & - \\
\hline Holanda & 24,2 & 52,4 & 7,2 & 7,1 & 3,2 & 2,9 & - & 3,0 \\
\hline Africa \\
do Sul & 33,0 & 31,0 & 12,0 & 7,0 & 7,0 & - & 0,0 & 9,0 \\
\hline Suécia & $35-45$ & $25-35$ & $6-8$ & $8-10$ & $2-4$ & $2-4$ & - & $6-9$ \\
\hline Suiça & 20,8 & 33,0 & 8,7 & 13,4 & 5,9 & - & - & 9,6 \\
\hline Gră- & 33,9 & 23,4 & 14,4 & 4,2 & 7,1 & 4,1 & - & 12,9 \\
Bret. & & & & & & & & \\
\hline USA & 35,6 & 29,0 & 8,4 & 7,3 & 8,9 & 2,0 & - & 8,7 \\
\hline Brasil & 14,4 & 64,4 & 1,1 & 12,0 & 3,2 & - & - & 4,5 \\
\hline Fon & & & & & & & -1 \\
\hline
\end{tabular}


A tabela 4 apresenta um resumo do destino final de resíduo doméstico em vários países. A disposição em aterros sanitários é pouco utilizada no Japão e Suíça, e muito utilizada na Finlândia, Canadá e Polônia (acima de 95\%). O Japão lidera, com valor de $68 \%$, no uso da tecnologia de incineração de resíduos como resultado da baixa disponibilidade de uso do solo para os fins em discussão. Neste contexto, observa-se uma diferença clara acerca do destino final dos residuos no Brasil em relação aos países desenvolvidos. Enquanto países desenvolvidos, como exemplificado acima, estão investindo na recuperação e incineração, o Brasil possui um quadro alarmante onde $99 \%$ do resíduo gerado é disposto sobre o solo. Deste montante, cerca de $76 \%$ é disposto a céu aberto e $13 \%$ em aterro controlado (IPT, 1994).

Além disso, vale ressaltar que existem muitos locais desativados, onde existiram antigos lixões. Nestes, o controle de recebimento de resíduo foi menor e geralmente os resíduos industriais e domésticos encontram-se misturados. Portanto, a contaminação dos recursos hídricos torna-se patente, e ainda, o risco à saúde da população que reside nas circunvizinhanças destas áreas é bastante preocupante. Neste cenário, a Região Metropolitana de São Paulo possui 116 lixões e aterros sanitários, onde o diagnóstico sobre o efeito que estas áreas de disposição de resíduos tem sobre os recursos hídricos e a saúde pública é extremamente modesto. Na realidade, existem vários trabalhos desenvolvidos pelas universidades, órgãos do governo e empresas privadas. Contudo, esses trabalhos normalmente possuem caráter específico, tanto em área física como também no aspecto da abordagem técnico-científica, dificultando uma visão global do problema. Conseqüentemente, através dos estudos existentes não é possível realizar uma gestão global adequada das áreas de disposição.

No Brasil, ainda não existe um sistema municipal, estadual ou federal de classificação de áreas contaminadas de forma a priorizar as áreas críticas como existe na América do Norte ou na Europa. Um dos documentos existentes, publicado recentemente pelo Instituto de Pesquisas Tecnológicas (IPT), é o "Manual de Gerenciamento Integrado sobre Lixo Municipal". Neste documento (IPT, 1994), o enfoque principal compreende os seguintes tópicos: origem, composição, limpeza, tratamento (segregação, reciclagem e incineração) e legislação sobre resíduos sólidos domésticos. De forma suscinta, são abordadas descrições sobre disposição final do lixo, com enfoque na conceituação do lixão e aterro sanitário, na transformação de lixão em aterro sanitário, na remediação e fechamento de lixões (ações mitigadoras) e nos estudos para a viabilização de áreas para instalação de aterros sanitários e projeto de aterro sanitário em áreas 
Tabela 4. Destino final de residuo doméstico (\%)

\begin{tabular}{|c|c|c|c|c|c|}
\hline País & $\begin{array}{l}\text { Aterro } \\
\text { Sanitário }\end{array}$ & Incineração & Reciclagem & $\begin{array}{l}\text { Compostage } \\
\mathrm{m}\end{array}$ & $\begin{array}{l}\text { Sem } \\
\text { serviço }\end{array}$ \\
\hline Austria & 64 & 20 & - & 16 & - \\
\hline Canadá & 95 & 4 & 1 & - & - \\
\hline Dinamarca & 31 & 50 & 18 & 1 & - \\
\hline Finlândia & 95 & 2 & 3 & - & $\begin{array}{l}- \\
-\end{array}$ \\
\hline França & 47,9 & 41,9 & 0,6 & 8,7 & - \\
\hline Alemanha & 74 & 24 & - & 2 & - \\
\hline Itália & 83,2 & 13,9 & 0,6 & 2,3 & - \\
\hline Japão & 29,6 & 67,6 & - & 2,8 & - \\
\hline Holanda & 51 & 34 & 15 & - & - \\
\hline Polónia & 99,9 & - & - & 0,1 & - \\
\hline $\begin{array}{ll}\begin{array}{l}\text { Africa } \\
\text { sul }^{1}\end{array} & \text { do } \\
\end{array}$ & 69,2 & 20,8 & 3,1 & 3,8 & $\overline{3,9}$ \\
\hline Suécia & 35 & 60 & 5 & - & - \\
\hline Suíça & 20 & 80 & - & - & - \\
\hline $\begin{array}{l}\text { Gră- } \\
\text { Bretanha }\end{array}$ & 88 & 11 & 1 & - & - \\
\hline USA & 83 & 6 & 11 & - & - \\
\hline Brasil $^{2}$ & 23 & 0,1 & - & 0,9 & 76 \\
\hline
\end{tabular}

Fonte: Carra, et al (1990) e IPT(1994)

(1) 225 aterros de um total de 564 áreas não possuem controle

(2) $10 \%$ aterro sanitário $+13 \%$ aterro controlado 
novas. Assim esse importante documento publicado por IPT (1994), que é dirigido principalmente aos técnicos dos órgãos municipais, trata principalmente de assuntos de interesse para gerenciamento de cada unidade de disposição de resíduos sólidos considerando as áreas existentes e a serem instaladas.

Da mesma forma, enfocando específicamente a área de disposição de resíduos existe o manual elaborado pela CETESB (1987) sobre a construção de aterros sanitários e industriais de forma a dispor resíduos no solo de maneira mais segura. Entretanto, existem poucos estudos sobre a forma de gerenciamento das áreas de disposição já existentes, e sobre o início e implementação deste gerenciamento. $O$ trabalho aqui apresentado procura sanar esta lacuna na questão do gerenciamento das áreas de disposição de resíduos. 


\section{PARTE 1 FUNDAMENTOS E ESTRATÉgIAS DE GESTÃo DE ÁREAS CONTAMINADAS}

Nesta primeira parte da tese apresenta-se inicialmente uma revisão bibliográfica da metodologia de gestão de áreas contaminadas em vários países. Em seguida o enfoque do trabalho é dado para o modelo de gestão de áreas contaminadas elaborada para a RMSP e no final desta parte é apresentada a metodologia de gestão de áreas de disposição de resíduos sólidos para RMSP.

\section{TÉCNICAS E MÉTODOS EXISTENTES DE GESTÃO DE ÁREAS CONTAMINADAS}

Os programas existentes, no país e no exterior, que pretendem preservar e proteger a integridade ambiental do meio físico, enfocam duas linhas básicas: a ação corretiva, voltada especificamente à recuperação de locais contaminados ou degradados, como é o caso dos locais de disposição de resíduos sólidos; e a ação preventiva, voltada à uma região de interesse, onde são estabelecidas restrições ao uso da terra frente às diversas atividades contaminantes, ou potencialmente contaminadoras.

O desafio, para a implantação desses programas, é identificar onde se encontram os problemas, caracterizá-los caso a caso, e posteriormente estabelecer prioridades, com base nos riscos existentes, concentrando os esforços técnicos e os investimentos, de acordo com interesses sócio-políticos. Tais programas devem ser desenvolvidos de uma maneira ordenada, com o objetivo de remediar as áreas existentes de uma forma racional, ou ainda, alocar adequadamente futuros empreendimentos potencialmente contaminadores.

A seguir são apresentas as experiências existentes no país e no exterior sobre os programas de preservação e proteção ambiental voltadas ao meio físico. 


\subsection{Experiência na Alemanha}

$\mathrm{Na}$ Alemanha, as áreas com atividades contaminantes, herdadas ou existentes, são caracterizadas e classificadas em três categorias para priorizar as ações técnicas e financeiras: áreas potencias, suspeitas e contaminadas. Inicialmente, na região de interesse, as áreas são classificadas como áreas potenciais em função do tipo de atividade existente. Posteriormente, a reclassificação da área potencial para área suspeita é feita através de um sistema de pontuação considerando os recursos ambientais água, solo e ar, e a saúde pública. Por final, a definição (caracterização e classificação) da área como contaminada é feita através de uma confirmação científica pelas autoridades competentes.

No início da década de 80 , várias agências estaduais de meio ambiente elaboraram um sistema de caracterização, classificação e priorização das áreas contaminadas. $\mathrm{Na}$ realidade, os sistemas elaborados em cada agência possuem diferenças principalmente em relação ao nível de exigência do limite de remediação dos locais contaminados.

Neste contexto, foi apresentado por MUBW (1988) um manual de áreas contaminadas (Altlasten-Handbuch-Ministerium für Umwelt Baden-Württemberg) elaborado pela agência de meio ambiente do Estado de Baden-Württemberg. Nesse Estado foram levantados sistematicamente 6.500 locais suspeitos, dos quais 1.200 localizam-se em áreas de mananciais de abastecimento público ou em zonas que futuramente serão aproveitadas como mananciais de abastecimento público.

Da mesma forma o estado de Nordheim-Westphalen apresentou um sistema de classificação em 1991 que, conceitualmente, assemelha-se ao de Baden-Württemberg.

Dessa maneira, os estados alemães defrontam-se com muitas áreas contaminadas onde as informações disponiveis são limitadas. Entretanto, considerando que para a classificação das áreas potenciais, suspeitas e contaminadas é necessário um procedimento de avaliação uniforme, foi elaborado naqueles estados um sistema que permite, com base em pequena quantidade de informação, uma apreciação mais ampla e uniforme do potencial de risco, que possibilita o diagnóstico e a tomada de decisões sobre as providências necessárias para a recuperação ou contenção da contaminação. 
O conceito básico do sistema alemão é de que, uma área potencial, em princípio, pode conter materiais que impõem um perigo potencial aos recursos ambientais. Estes materiais podem apresentar seus efeitos prejudiciais, isto é, transformam-se em contaminantes somente quando entram em contato com o recurso. Assim, na averiguação do risco para os recursos ambientais, além do risco inerente à periculosidade da substância, são distingüidos os riscos provenientes dos seguintes equilibrios e processos:

(1) Liberação de substâncias nocivas provenientes do local;

(2) Entrada de substâncias nocivas nos recursos ambientais;

(3) Transporte (migração) e efeitos das substâncias nocivas no recurso ambiental.

O sistema alemão caracteriza-se por ser um método numérico ponderado e cumulativo. Dessa forma, a avaliação de um local suspeito ou contaminado é feita em várias etapas. As etapas são consideradas em seqüência, porém, independentes umas das outras, pois cada etapa é ponderada de acordo com a sua qualificação técnica.

Assim, partindo-se da existência da periculosidade de uma substância (r0) que resulta do estabelecimento de uma situação padronizada de disposição de lixo ou solo contaminado, o local pode ser avaliado em três etapas distintas: a liberação (I), a entrada (II) o transporte e efeitos (III). A quantificação da condição real do local leva à pontuação dos riscos rI, rII e rIII. As ações ou fatos que podem levar à minimização ou ao aumento do risco são expressas através de multiplicadores $\mathrm{m}$ (mI, mII e mIII). Assim a avaliação do risco do local de interesse é calculada da seguinte forma:

$$
\begin{aligned}
& \mathrm{rI}=\mathrm{ml} . \mathrm{r0} \\
& \mathrm{rII}=\text { mII.rI } \\
& \mathrm{rIII}=\text { mIII.rII }
\end{aligned}
$$

O risco real é obtido com uma ponderação final (mIV) que considera a importância do recurso ambiental, chegando-se assim à pontuação final rIV = mIV.rIII. 


\subsection{Experiência do Canadá}

No Canadá, em função do aumento do grau de consciência e de preocupação da população em relação ao risco à saúde e ao meio ambiente causado por áreas contaminadas, o Conselho Canadense do Ministério do Meio Ambiente (Canadian Council of Ministers of the Environment - CCME) iniciou o Programa Nacional de Remediação de Áreas Contaminadas (National Contaminated Sites Remediation Program - NCSRP) para a avaliação e remediação das áreas contaminadas de alto risco existentes naquele país. Com o intuito de elaborar uma avaliação consistente das áreas contaminadas, o CCME requisitou à comunidade técnico-científica daquele país o desenvolvimento do Sistema Nacional de Classificação de Áreas Contaminadas (National Classification System for Contaminated Sites).

O Sistema Nacional de Classificação de Áreas Contaminadas Canadense é uma ferramenta que permite a filtragem e priorização na avaliação de áreas contaminadas, de acordo com o grau potencial de impacto adverso à saúde humana e ao meio ambiente. $O$ sistema foi desenvolvido com base em consulta e revisão de uma extensa lista de literatura existente sobre o assunto naquele e em outros países. Além disso, foi realizado um intenso trabalho de levantamento de informações existentes sobre os tipos mais frequentes de áreas contaminadas no Canadá.

A metodologia referente ao Sistema Canadense encontra-se descrita em publicação do CCME (1992), composta por texto explicativo e disquete. No aspecto metodológico, o sistema prima pela facilidade de armazenamento e recuperação de informações, e por permitir uma atualização constante das informações. O Sistema Nacional de Classificação caracteriza-se por ser um método numérico cumulativo onde, ao final, cada característica da área é pontuada e somada. Este método, devido a sua simplicidade de manuseio e de fácil compreensão, é largamente utilizado na avaliação ambiental onde o objetivo final requer decisão em vários atributos. A metodologia baseia-se no fato de que, qualquer efeito adverso sobre o meio ambiente e saúde humana provém de uma cadeia de eventos, iniciando-se na fonte e terminando no receptor. Por exemplo, a cadeia de eventos que resulta na ingestão de águas subterrâneas é ilustrada no quadro 1 abaixo. 
Quadro 1. Exemplo de cadeia de eventos da fonte para o receptor (CCME 1992)

\begin{tabular}{|c|c|c|c|c|}
\hline FONTE & RISCO & LIBERAÇÃO & CAMINHO & RECEPTOR \\
\hline $\begin{array}{c}\text { Resíduo } \\
\text { Armazenado na } \\
\text { Área A }\end{array}$ & $\begin{array}{c}\text { Natureza e } \\
\text { quantidade do } \\
\text { resíduo } \\
\text { armazenado na } \\
\text { Área A }\end{array}$ & $\begin{array}{c}\text { Vazamento do } \\
\text { local de } \\
\text { armazenamen-to }\end{array}$ & $\begin{array}{c}\text { Movimento dos } \\
\text { contaminantes } \\
\text { através da água } \\
\text { subterrânea }\end{array}$ & $\begin{array}{c}\text { Poço tubular } \\
\text { Usuário ingere } \\
\text { água } \\
\text { contaminada }\end{array}$ \\
\hline
\end{tabular}

O Sistema Nacional de Classificação foi elaborado para avaliar o risco potencial das áreas através da pontuação das características da área, que podem ser agrupadas em três categorias.

(1) Característica do Contaminante - O risco relativo do contaminante estar presente na área.

(2) Caminhos de exposição - A rota provável que o contaminante pode seguir (água subterrânea, água superficial, contato direto, ar, etc) em direção ao receptor.

(3) Receptores - Seres vivos ou recursos que podem estar expostos ou afetados pela contaminação (ser humano, plantas, animais e recursos ambientais).

\subsection{Experiência nos E.U.A.}

Nos E.U.A, LE GRAND (1964) propôs a primeira cartografia de vulnerabilidade e análise de cargas contaminantes provenientes de sistemas de Disposição de Águas Servidas (Surface Impoundment Assessment). Este método avalia, de forma distinta, a vulnerabilidade natural e a carga contaminante. Os parâmetros utilizados no método são: tipo litológico, espessuras da zona não-saturada e saturada, e Sólidos Totais Dissolvidos (STD).

HAGERTY et al. (1973) elaboraram o método "Site Ranking System" para a avaliação de áreas potenciais para a disposição de produtos químicos e de atividades em operação. $\mathrm{O}$ método analisa vários fatores, tais como: características de sorção e hidráulica do solo; hidrodinâmica do aquífero, contaminação do ar e risco de toxicidade à saúde humana.

PHILIPS et al. (1977) elaboraram a metodologia denominada Waste Soil-Site Interaction Matrix para avaliar os perigos da disposição de resíduos sólidos e líquidos de origem industrial no 
solo. O método é bastante abrangente, e entre vários parâmetros considera a ocupação do local, vários aspectos da zona não-saturada e saturada, comportamento dos contaminantes, características físico-químicas das substâncias nocivas.

Mais recentemente, o fato que permitiu uma ação mais eficaz e realística em relação às áreas contaminadas foi a aprovação da legislação federal denominada Comprehensive Environmental Response, Compensation and Liability Act, conforme descrito por CLEARY (1989).

A Agência de Proteção Ambiental Americana (U.S. Environmental Protection AgencyUSEPA), criou em 1992, o sistema de classificação denominado The Hazard Ranking System (HRS), que permitiu a elaboração da lista nacional de áreas prioritárias (National Priorities List NPL). O HRS é uma ferramenta que permite a filtragem e priorização na avaliação das várias áreas com potencial de liberação de substâncias nocivas que causam danos à saúde humana e ao meio ambiente. O HRS permite uma medida de risco relativo, ao contrário de outras formas de avaliação, nas quais o risco absoluto é obtido. A medida do risco relativo pode ser consistentemente aplicada para uma grande variedade de áreas contaminadas, inclusive lixões e aterros sanitários.

O Sistema da USEPA (1992) é mais complexo que o da Alemanha e Canadá, exigindo informações e parâmetros mais detalhados em relação aos sistemas até aqui apresentados, mas com concepção filosófica similar. Assim, no HRS, a pontuação final é uma resultante da avaliação de quatro caminhos preferenciais ("pathways") de contaminação:

- migração pelas águas subterrâneas (Sgw);

- migração pelas águas superficiais (Ssw);

- exposição do solo (Ss); e

- migração pelo ar (Sa).

Para a água subterrânea e ar, é utilizada uma avaliação onde o potencial de migração é único até atingir o receptor. No caso da água superficial e solo as possibilidades são múltiplas. Para as águas superficiais existem basicamente três caminhos potenciais: água ingerida, cadeia alimentar, e cadeia ambiental. Estes caminhos potenciais são avaliados e separados para dois componentes de migração: migração aquática /terrestre e migração da água subterrânea para água 
superficial. Para o solo são avaliados dois caminhos potenciais: população residente e população do entorno.

O cálculo da pontuação do HRS para áreas contaminadas é inicialmente calculado para cada um dos quatro caminhos preferenciais, sendo posteriormente associados através da equação apresentada abaixo para determinar a pontuação final do HRS, o qual varia entre 0 a 100.

$\mathrm{S}=\sqrt{\left(\mathrm{Sgw}^{2}+\mathrm{Ssw}^{2}+\mathrm{Ss}^{2}+\mathrm{Sa}^{2}\right) / 4}$

\subsection{Experiência no Brasil}

No Brasil, a gestão das áreas contaminadas foi delineada apenas prevendo a proteção das águas subterrâneas. Nesta linha TALTASSE (1972) apresentou o primeiro mapa de vulnerabilidade da região de Campinas. O trabalho avaliou a condutividade hidráulica e característica de sorção das diferentes formações geológicas que ocorrem na região em questão.

Posteriormente, DUARTE (1980) propôs uma metodologia de mapeamento de vulnerabilidade para aquíferos freáticos considerando o comportamento de contaminantes em vários tipos litológicos, solos e áreas de recarga.

Recentemente, o Instituto Geológico (IG/SMA) em convênio com a Companhia de Tecnologia Ambiental (CETESB) e o Departamento de Águas e Energia Elétrica (DAEE) desenvolveram o mapeamento da vulnerabilidade e risco da poluição das águas subterrâneas no Estado de São Paulo (HIRATA et al. 1991, HIRATA et al. 1992), IG/CETESB/DAEE (1997) em escala 1:500.000. Esse projeto utilizando-se do método desenvolvido por FOSTER \& HIRATA (1988) para a Organização Pan Americana da Saúde (OPAS), analisou a vulnerabilidade natural dos principais aquíferos paulistas e a carga contaminante potencial de fontes pontuais (indústrias, aterros e lixões, atividade mineral) e dispersas (agricultura e saneamento "in situ"). A integração entre os dados definiu áreas/atividades de maior risco de contaminação dos recursos hídricos.

O método acima descrito, entre os aplicados no país, apresenta uma grande vantagem pela sua simplicidade e pela avaliação de um reduzido número de parâmetros. Este método avalia 
separadamente a vulnerabilidade natural dos aquiferos e o potencial de contaminação das atividades antrópicas existentes. A determinação da vulnerabilidade dos aquíferos é baseada em uma ponderação numérica como mostra a figura 1. Este método é empirico e engloba três fatores. O primeiro consiste na identificação do tipo de ocorrência da água subterrânea, num intervalo de 0-1,0. O segundo trata da especificação do tipo litológico acima da zona saturada do aquífero, com a discriminação do grau de consolidação (presença e ausência de permeabilidades secundárias) e das características granulométricas. Este fator é representado numa escala de 0,31,0 , além de sufixos para os casos de tipos litológicos que apresentem fissuras ou baixa capacidade de atenuação de contaminantes. O terceiro fator é a estimativa da profundidade do nível da água (ou do topo do aquífero confinado), numa escala de $0,4-1,0$. $O$ produto destes três parâmetros é o índice de vulnerabilidade, expresso numa escala de $0-1$, em termos relativos. A avaliação do potencial de contaminação induzida pelas atividades existentes considerou, de forma geral, três fatores: tipo de substância nociva existente, concentração e forma de ocorrência.

\section{MODELO DE GESTÃO DE ÁREAS CONTAMINADAS ELABORADA PARA RMSP}

Conforme apresentado no ítem anterior existem poucos programas abrangentes implantados sobre prevenção e proteção ambiental voltadas ao meio físico. Neste capítulo da tese pretende-se apresentar uma proposta de metodologia de modelo de gestão de áreas contaminadas.

Há que se ressaltar que, o tema abordado nesta tese faz parte de um projeto maior denominado "Recuperação do Solo e das Águas Subterrâneas em Áreas de Disposição de Resíduos Industriais", patrocinado pela Gesellschaft Für Technische Zusammenarbeit (GTZ) da Alemanha e executado pela Companhia de Tecnologia de Saneamento Ambiental (CETESB) com colaboração do Instituto Geológico (IG/SMA).

o projeto visa o gerenciamento de áreas potencialmente contaminadas, suspeitas de contaminação ou comprovadamente contaminadas na Região Metropolitana de São Paulo (RMSP). O gerenciamento das áreas em questão, na realidade, é um processo que visa principalmente identificar e avaliar áreas potencialmente contaminadas dentro de uma região de interesse, proporcionando assim o estabelecimento e realização de medidas visando a prevenção, contenção e remediação destas, tendo como base o posicionamento e a importância dos bens a 


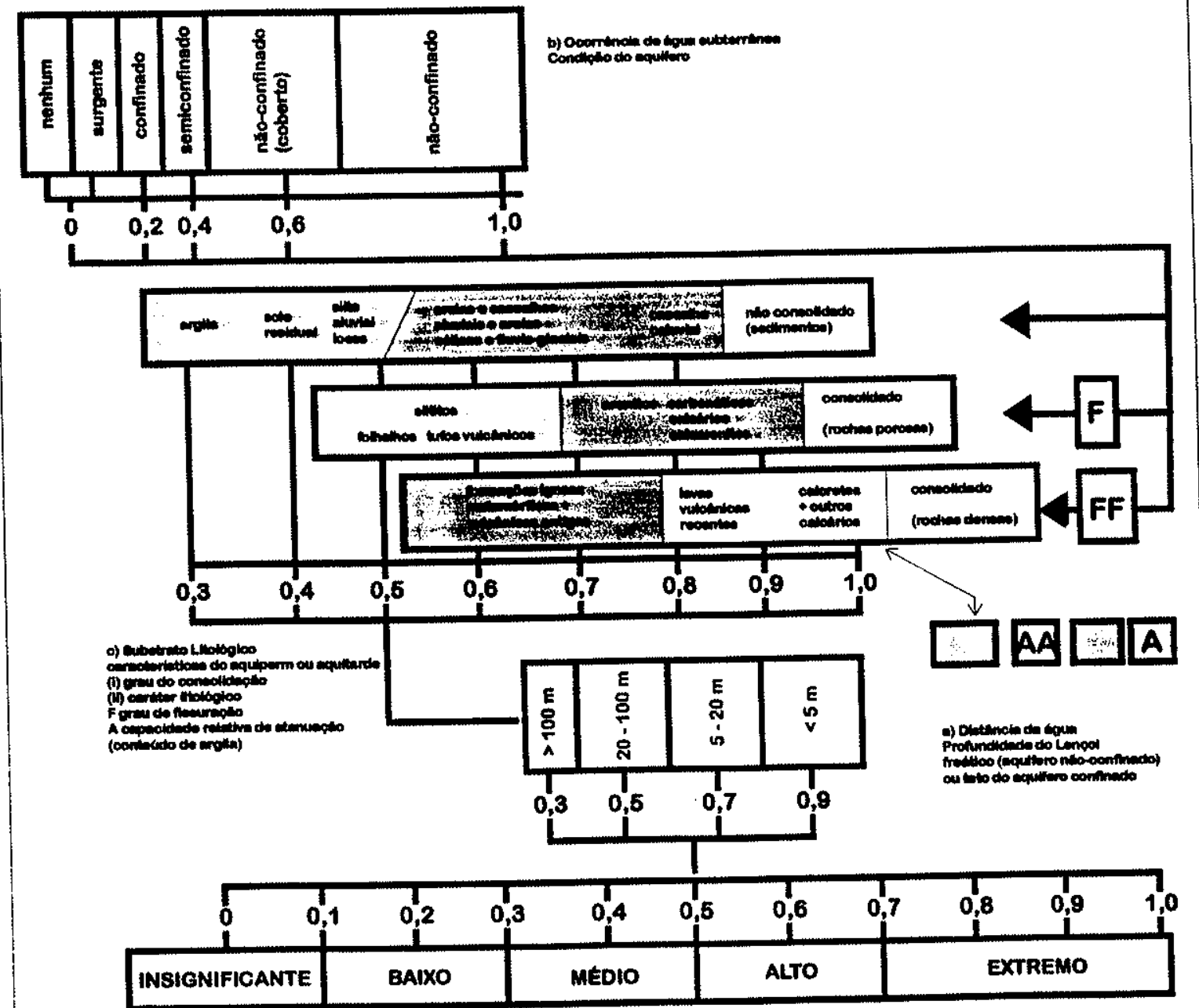

FIGURA 1 - Sistema para avaliaçăo do indlice de vulnerabilidade do aquifero (FOSTER \& HIRATA, 1988) 
proteger (CETESB, prelo). Outro objetivo do gerenciamento é o fornecimento de informações, para os órgãos de controle e planejamento ambiental, prefeituras, sociedade civil e iniciativa privada sobre as áreas potencialmente contaminadas, suspeitas de contaminação ou comprovadamente contaminadas presentes na região de interesse, subsidiando as ações de controle e planejamento.

No processo, que envolve desde a identificação de áreas contaminadas até a sua remediação, existem responsabilidades que são do poder público e outras que são do causador da contaminação, que na maioria dos casos tem origem na iniciativa privada. Dessa forma, no sistema de gerenciamento apresentado neste trabalho estão descritos os procedimentos que cabem principalmente ao poder público.

\subsection{Conceituação Técnico-Científica}

O Sistema de Gerenciamento de Áreas Contaminadas apresentado neste trabalho baseiase no sistema adotado pelo Estado de Nordheim-Westphalen (Alemanha) mas, caracteriza-se por considerar um universo maior de atividades. Enquanto o sistema alemão considera apenas locais de disposição de resíduos e indústrias desativadas, o sistema apresentado neste trabalho amplia os tipos de atividades consideradas, permitindo também avaliar áreas industriais ativas, áreas comerciais, postos de serviços e outros (acidentes e áreas agrícolas).

O fato que diferencia a Alemanha do Brasil, ou ainda do nosso continente, é o período de existência do país. Assim, na Alemanha, as antigas áreas de disposição de resíduos e indústrias são, em número, muito maiores e complexas em relação ao nosso continente. Além disso, as informações sobre a atividade de interesse como projeto, controle, matéria prima, resíduo e/ou registros históricos não encontram-se sistematizados e disponíveis como na Alemanha. Na prática, as áreas potenciais, suspeitas e contaminadas são problemas ambientais complexos que precisam ser estudados, de uma forma rápida e criteriosa, devido ao seu significado intrínseco para a proteção dos recursos naturais e da saúde pública no país. Apesar de cada caso apresentar particularidades e complexidades próprios, o sistema de gerenciamento a ser aplicado nestas áreas requer um procedimento uniforme, mesmo quando se considera um pequeno volume de informações disponíveis. Assim, o intuito básico do sistema de gerenciamento é permitir uma 
apreciação ampla e uniforme do potencial de risco de contaminação dos recursos naturais e saúde pública nas áreas em questão, e ainda, possibilitar o ordenamento e priorização de ações e/ou medidas de prevenção, controle e remediação.

Os termos mais importantes dentro da concepção do gerenciamento de áreas contaminadas neste trabalho são: área potencial, área suspeita e área contaminada.

Área potencial pode ser definida como uma atividade ou local que pode vir a alterar a qualidade dos recursos ambientais, acima dos padrões definidos em lei. Dessa forma, conceitualmente, ela não significa obrigatoriamente que esteja causando dano ao recurso ambiental no momento. Quando a atividade ou o local for considerado como área potencial significa que, em função do manuseio de produtos perigosos e/ou geração de efluentes/resíduos tóxicos podem ocorrer acidentes, vazamentos, ou outras formas de transferências de substâncias nocivas aos recursos naturais.

A área suspeita é uma atividade ou local que previamente foi considerada como área potencial. A diferença entre uma área potencial e suspeita reside na forma de avaliação do risco potencial de contaminação. $\mathrm{Na}$ área potencial, o risco é inerente apenas ao tipo de atividade, considerando-se as substâncias nocivas associadas. Para a classificação das áreas suspeitas, além dos riscos associados à atividade, é avaliado o risco associado aos bens a proteger, considerando desde sua existência e vulnerabilidade à contaminação.

A área contaminada é uma atividade ou local que previamente foi considerada como área suspeita e potencial. O mesmo procedimento adotado nas duas áreas anteriores também é empregado neste caso, ocorrendo uma classificação e priorização para reduzir o universo numérico de uma área para a outra. $O$ instrumento utilizado para a priorização é uma investigação rápida no campo que permite comprovar cientificamente a contaminação do recurso ambiental. Neste caso, a classificação das áreas suspeitas, em termos de maior ou menor perigo aos bens a proteger, vem nortear os estudos para comprovação da existência ou não de contaminação. No caso dos recursos hídricos subterrâneos, o instrumento pode ser, por exemplo, uma investigação geofísica em terrenos onde a contaminação é por compostos inorgânicos, ou ainda, a utilização de "soil gas survey" para compostos orgânicos voláteis, ou também, para casos extremos, uma coleta simples de amostra de solo ou água subterrânea seguida de análise química. 
Assim, no gerenciamento de áreas contaminadas, a estratégia básica é reduzir, através da utilização de metodologia racional e científica, o grande universo de áreas/atividades para um número restrito de áreas que realmente têm possibilidade de estar contaminada, otimizando investimentos financeiros e de tempo durante o processo, facilitando também o manuseio de informações necessárias para cada etapa. Neste contexto, a classificação em três categorias de áreas como conceituadas acima faz se necessária.

\subsection{Sistema de Gerenciamento de Áreas Contaminadas}

Na prática, o processo de gerenciamento de áreas contaminadas, constitui-se de uma sequência de etapas, conforme apresentado no fluxograma da figura 2. No fluxograma encontramse sintetizados, além das três categorias de áreas descritas acima, outras etapas que são importantes e devem ser consideradas no procedimento de gestão de áreas contaminadas.

Uma vez definida a região de interesse e identificados os bens a proteger, a ferramenta primordial do gerenciamento é o cadastro das áreas contaminadas. É necessário identificar, no universo de atividades existentes, aquelas que vêm causando impactos que afetam nocivamente os bens a proteger. $O$ cadastro deve identificar as áreas que apresentem risco de contaminação inerente à sua própria atividade, que são denominadas de áreas potenciais (APs). Após uma avaliação prévia das APs, elas devem passar à categoria de áreas suspeitas (ASs), as quais são classificadas de forma a priorizar as ações de confirmação da contaminação. Caso seja comprovada, elas são transferidas para a categoria de áreas contaminadas (ACs), devendo então passar por um processo de caracterização da contaminação e de recuperação do local, caso seja necessário.

\subsubsection{Definição da região de interesse e dos bens a proteger}

A região onde pretende-se implantar o gerenciamento de áreas contaminadas, deve ser estabelecida considerando-se as características dos tipos de atividades, meio físico, os recursos ambientais e a saúde pública (FIGURA 2).

$\mathrm{Na}$ definição do perímetro da região ou da área de interesse para o gerenciamento de áreas contaminadas, deve ser considerado, não somente os contornos do meio físico como bacias 


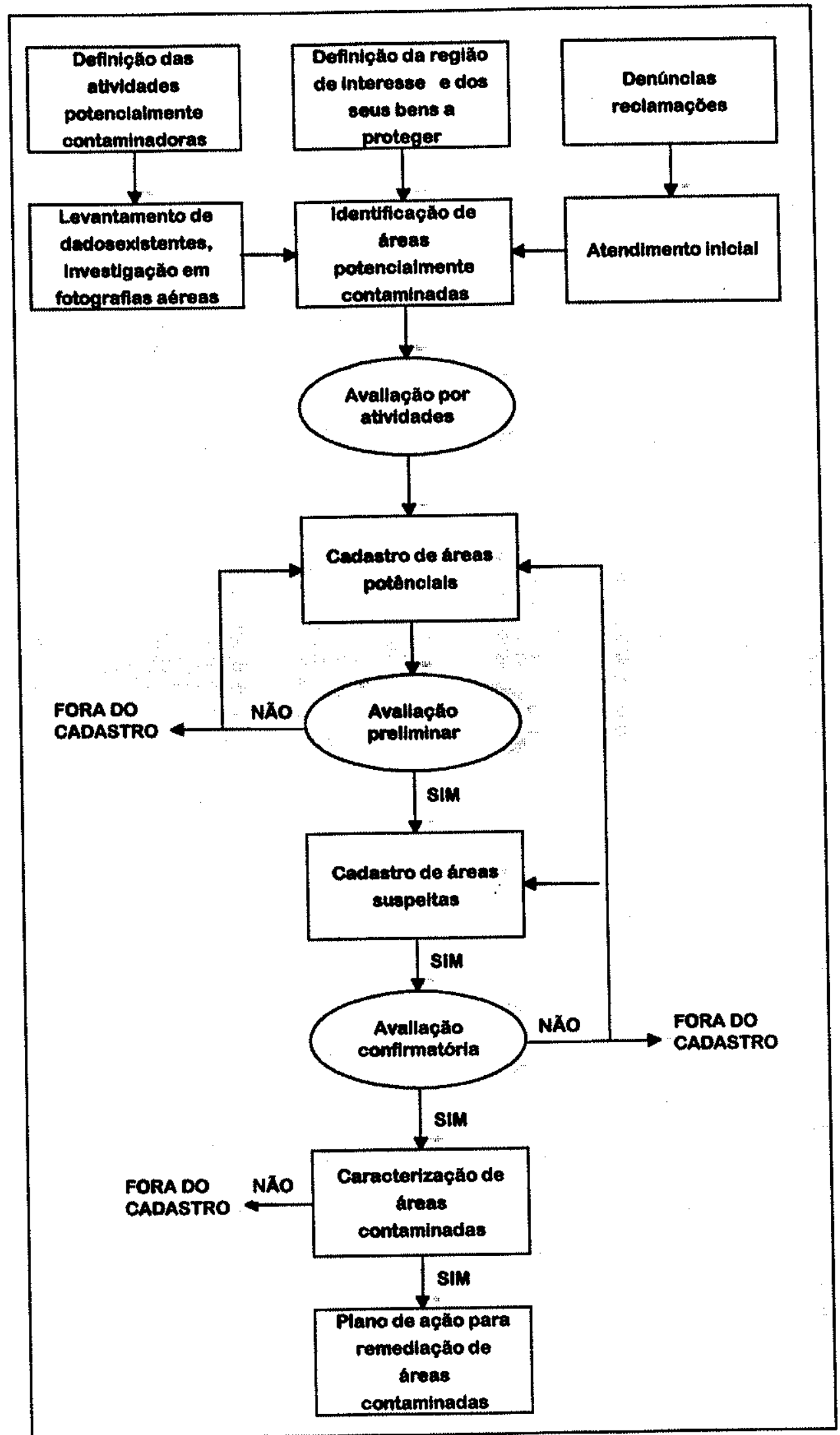

FIGURA 2 - Fluxograma de gerenciamento de areas contaminadas (modificado de Gloeden, no prelo) 
hidrográficas, aqüíferos importantes, unidades litoestratigráficas, unidades geomorfológicas, mas também, outros fatores tais como limites administrativos municipais, estaduais e federais adotados pelos órgãos privados e públicos.

A metodologia de gerenciamento de áreas contaminadas pode ser aplicada em qualquer âmbito do poder público (federal, estadual e municipal). Uma das principais ferramentas de trabalho nesta metodologia é a cartografia básica e temática. Assim, dependendo das dimensões da área de interesse escolhida, faz-se necessário definir a escala de trabalho que pode ser, respectivamente, regional, semi-detalhe e local. Para o Brasil, que possui dimensões continentais, a escala de trabalho mais adequada é $>1: 1.000 .000$, em nível de estado, $>1: 250.000$ e quando escolhido o recorte municipal, $<1: 50.000$ (QUADRO 2).

Quadro 2. Níveis de escalas de trabalho (modificado de HIRATA, 1994)

\begin{tabular}{|c|c|c|}
\hline NIVEL DE AVALIAÇĀO & $\begin{array}{c}\text { INFORMAÇÓES E } \\
\text { TRABALHOS } \\
\text { NECESSÁRIOS }\end{array}$ & ESCALAS DE TRABALHO \\
\hline $\begin{array}{l}\text { I. Reconhecimento } \\
\text { Preliminar } \\
\text { (existência do risco) }\end{array}$ & \multirow{3}{*}{$\begin{array}{l}\text { - Ênfase em } \\
\text { existentes } \\
\text { - Sem Perfuração } \\
\text { - Sem Amostras } \\
\text { - } \begin{array}{l}\text { Ênfase em aspectos } \\
\text { qualitativos }\end{array}\end{array}$} & $\begin{array}{c}\text { Federal } \\
(>1: 1.000 .000) \\
\text { Estadual } \\
(1: 250.000 \text { a } 1: 500.000) \\
\end{array}$ \\
\hline $\begin{array}{l}\text { II. Avaliaçăo Sistemática } \\
\text { (grau de risco) }\end{array}$ & & $\begin{array}{l}\text { Regioes Metropolitanas e Municípios } \\
(<1: 100.000)\end{array}$ \\
\hline $\begin{array}{l}\text { III. Reconhecimento de } \\
\text { Campo }\end{array}$ & & $\begin{array}{c}\text { Urbano (Distritos e Bairros) } \\
(1: 50.000 \text { a } 1: 10.000)\end{array}$ \\
\hline $\begin{array}{l}\text { IV.Reconhecimento por } \\
\text { Rede de Monitoração }\end{array}$ & \multirow{2}{*}{$\begin{array}{l}\text { - Requer coleta de dados de } \\
\text { campo } \\
\text { - Requer perfuração } \\
\text { - Requer amostragem e } \\
\text { análises } \\
\text { - Ênfase em aspectos } \\
\text { quantitativos }\end{array}$} & $\begin{array}{c}\text { Local } \\
(1: 25.000 \text { a } 1: 5.000)\end{array}$ \\
\hline $\begin{array}{l}\text { V. Investigação Completa } \\
\text { de Campo }\end{array}$ & & $\begin{array}{c}\text { Local } \\
(<1: 10.000)\end{array}$ \\
\hline
\end{tabular}

Os recursos ambientais e outros bens a proteger podem ser classificados de acordo com a sua importância dentro da região de interesse, podendo, esta classificação, por exemplo, ser a base para a seleção inicial de APs a serem avaliadas.

Entre os bens a proteger identificados na RMSP, podem ser destacados:

- Solo: áreas destinadas à agricultura, parques.

- Água superficial: mananciais (Guarapiranga, Billings, Cantareira)

- Águas subterrânea: poço de abastecimento público e privado 
- Saúde Humana: área urbana

- Vegetação: Área de Proteção Ambiental, parques, áreas agrícolas.

A própria RMSP pode ser selecionada como uma região de interesse por apresentar muitos conflitos de uso e ocupação, seja nas áreas urbanas seja nas áreas industriais.

\subsection{2. Áreas potenciais (APs)}

A identificação de APs certamente pressupõe a definição preliminar da região de interesse e dos bens a proteger, das atividades potencialmente contaminadoras e, das denúncias e reclamações. $O$ processo de identificação de áreas potencialmente contaminadas permite o delineamento inicial do universo a ser abrangido no cadastro, com a definição das principais atividades que podem contaminar os recursos ambientais e causar prejuizos à saúde pública. Este processo, representa um primeiro nível de priorização, aqui denominado, priorização por atividades. $\mathrm{O}$ universo inicial de APs, nesta primeira etapa, passa a ser o principal elemento do cadastro.

a. Definição das atividades potencialmente contaminadoras ou fontes potenciais de contaminação

As atividades potencialmente contaminadoras são aquelas onde ocorre o manejo de substâncias e/ou resíduos, cujas características fisico-químicas, biológicas e toxicológicas podem implicar em riscos à qualidade do solo, água, ar e à saúde da população, etc., ou seja, implicam em riscos aos bens a proteger.

As APs, em áreas urbanas com saneamento básico, podem ser divididas em cinco categorias principais: disposição de resíduos, área industrial, área comercial, postos de serviços e acidentes. Estas fontes podem ser existentes e herdadas. Quando existentes, o procedimento legal e de custeio, desde a caracterização até a remediação, torna-se muito mais fácil. Por outro lado, quando a fonte é herdada, na maioria dos casos o proprietário não existe mais e a responsabilidade acaba recaindo sobre o poder público. Uma fonte herdada pode ser definida como uma área onde existiu uma atividade potencialmente contaminante, mas que atualmente encontra-se desativada, entretanto, os bens a proteger podem ainda continuar a sofrer os impactos negativos da atividade. 
Nos EUA, em 1985, foi criado o "Superfund", um fundo para custear os casos de remediação e estudos de contaminação de aqüiferos, nos quais as penalizações não cabiam aos antigos donos ou responsáveis, ou quando estes não possuiam capacidade financeira para tanto.

Segundo HIRATA (1994), no Reino Unido as antigas fábricas e oficinas de reparos de aviões de combate na II Grande Guerra causaram contaminações em aquiferos. $O$ estado tem arcado com os estudos necessários e tratamentos adequados.

Desta forma, analisando os diferentes processos industriais utilizados dentro da região de interesse pode-se reconhecer quais são as matérias primas utilizadas, os produtos e os resíduos gerados em uma determinada atividade industrial, permitindo assim a identificação, das várias atividades industriais, as quais podem ser classificadas como potencialmente contaminadora ou fontes potenciais de contaminação.

Por exemplo, as atividades de disposição de resíduos, produção e armazenamento de substâncias perigosas podem ser classificadas como atividades potencialmente contaminadoras.

\section{b. Identificação de Áreas Potencialmente Contaminadas}

Para a identificação de áreas potencialmente contaminadas é necessário, na prática, selecionar e caracterizar as atividades do homem que podem causar danos aos recursos ambientais e à saúde pública.

A identificação das áreas potencialmente contaminadas (APs) é fruto de três atividades: levantamento dos dados existentes em entidades públicas e privadas, interpretação de fotografias aéreas e levantamento das denúncias e reclamaç̃es (FIGURA 2).

\section{b.1. Levantamento de Informações existentes}

As áreas potencialmente contaminadas (APs) são identificadas, dentro da região de interesse, através dos levantamentos de dados existentes em entidades privadas e públicas, onde muitas das informações necessárias para a avaliação das APs, encontram-se nos órgãos de controle e de pesquisa, necessitando apenas de uma sistematização voltada ao gerenciamento. 
No caso das áreas de disposição de resíduos sólidos, normalmente as informações estão disponiveis nas prefeituras e órgãos públicos ambientais. Os resíduos são normalmente de origem doméstica, hospitalar ou industrial e têm sido causadores de inúmeros incidentes de contaminação das águas subterrâneas em nosso país (CASTRO NETO et al. 1984, GUIGUER 1987, BERNARDES JR et al. 1991). Como citado anteriormente, no Brasil $99 \%$ das áreas de disposição de resíduos não possuem impermeabilização inferior e superior, e drenos de chorume e gases, acredita-se que é razoável considerar todas as áreas de disposição de resíduos como áreas potenciais de contaminação.

\section{- Áreas Industriais e Comerciais}

As informações sobre as áreas industriais e comerciais normalmente estão disponíveis nos órgãos públicos ambientais. Vale ressaltar que, são consideradas aqui como atividades comerciais somente aquelas que manuseiam ou armazenam produtos perigosos. Como exemplos podem ser considerados alguns produtos provenientes do setor químico, farmacêutico, recuperação de resíduos e outros.

$\mathrm{Na}$ categoria das áreas industriais e comerciais existe uma diversidade muito grande de atividades, processos de manufaturas e armazenamento que normalmente dificulta a identificação da atividade potencialmente contaminadora dos recursos ambientais e nocivos à saúde pública. Segundo HIRATA (1994), os principais problemas que enviolvem a definição de áreas potenciais para as indústrias são:

- grande variedade de atividades industriais existentes;

- considerável variação no nível tecnológico de qualquer indústria;

- extrema e errática variação temporal nas concentrações de substâncias tóxicas nos efluentes;

- grande variação no uso e eficiência dos processos de tratamento para efluentes industriais e as incertezas sobre a efetividade na remoção de contaminantes potencialmente perigosos;

- falta de controle de qualidade e de análises químicas de efluentes e resíduos diversos, incluindo metais pesados e compostos organo-sintéticos; 
- falta de uma adequada informação publicada sobre as características de efluentes e resíduos de indústrias representativas, especialmente aquelas que funcionam em paises de economias periféricas;

- grande variedade nos modos de manuseio e disposição de matérias primas, resíduos sólidos e líquidos, incluindo a frequente adoção de práticas clandestinas.

Alguns ramos industriais e comerciais podem ser definidos como atividades potencialmente contaminadoras, entre elas podem ser citadas: mineração, energia, produtos químicos, farmacêuticos, produção e transformação de metais, equipamentos eletro-eletrônicos, papel, borracha, têxtil, couro, madeira e recuperação de resíduos.

\section{- Postos de Serviço}

Para os postos de serviços, normalmente as informações estão junto aos órgãos ambientais e empresas de distribuição de combustíveis automotivos. Segundo ALLERT et al (1987) estima-se que cerca de $35 \%$ do armazenamento de combustíveis nos EUA esteja vazando. Nos Países Baixos, o vazamento de tanques de combustíveis é responsável por $25 \%$ dos problemas de contaminação das águas subterrâneas. No Estado de São Paulo, no ano de 1993, houve 83 casos de vazamento de combustíveis em postos de serviços que foram notificados à CETESB.

Um estudo desenvolvido durante 6 meses pelo Pennsylvania Department of Environment Resources (1985) em vários postos de serviços no Estado da Pennsylvania mostrou que do total de casos de vazamentos comprovados, $49 \%$ estavam associados a tanques, $39 \%$ a tubulações e $12 \%$ a ambos. Problemas de perdas em tubos estavam relacionados aos primeiros anos de operação do sistema ( 0 a 10 anos). As principais causas de vazamentos de tanques e tubos foram atribuídas à corrosão (62\%), a perdas em encaixes (19\%) e a instalações inadequadas (13\%).

A corrosão de tanques e tubos é função do tipo de material, da idade do sistema, da agressividade do meio onde enterrados e da inexistência de proteções adicionais, como a catódica. Para a atividade de postos de serviços, a idade do sistema pode ser estabelecida como parâmetro para identificação de áreas potencialmente contaminadoras. 
No caso dos acidentes envolvendo caminhões e trens com cargas líquidas e sólidas tornase difícil a sua identificação. Entretanto, junto ao órgão de controle ambiental é possível recuperar registros de acidentes e, algumas vezes, através de reportagens em jornais. A identificação das rotas mais importantes de cargas perigosas é um registro mínimo que pode ser contabilizado para efeitos de cadastro.

\section{b.2. Uso de Fotografias Aéreas}

A interpretação de fotografias aéreas de uma determinada região pode auxiliar na identificação de novas APs que não estejam contempladas no levantamento das informações existentes. Nas fotos aéreas é possível identificar depósitos desconhecidos, em áreas próximas ou dentro de áreas industriais, que podem ser consideradas como fontes de contaminação ou estarem relacionadas a estas. Da mesma forma, deposições clandestinas de restos de materiais de construção e resíduos domésticos, também podem ser identificadas através da mesma técnica. Desta forma, o trabalho de fotointerpretação pode reconhecer e posicionar áreas que devem ser incluídas no cadastro de APs. O uso desta técnica implica na utilização de fotos aéreas em escala adequada (em geral superior a 1:10.000) e com recobrimento temporal para avaliar a evolução das áreas identificadas.

\section{b.3. Denúncia e/ou Reclamações}

As denúncias e reclamações feitas pela população, imprensa, entidades ambientalistas, empresas, etc., relativas a áreas com provável presença de contaminantes ou riscos a bens a proteger, também auxiliam na identificação de APs.

$\mathrm{O}$ atendimento inicial deve ser realizado através de uma inspeção pelo órgão de controle ambiental na área indicada pelo reclamante, com o objetivo de determinar a presença de uma atividade ou fonte potencialmente contaminadora, que possa ser responsável pelos problemas que geraram a reclamação. Uma vez identificada a atividade ou fonte potencial, a área poderá ser classificada e incluída no cadastro como uma AP. 
No caso de ser constatado o risco de incêndio e explosão durante esta etapa devem ser desencadeadas ações emergenciais cabíveis, e em seguida deve ser seguido o processo de avaliação para determinar se esta AP pode ser classificada como uma área suspeita ou contaminada.

\subsection{3. Áreas Suspeitas (ASs)}

Dentro do processo de gerenciamento de áreas contaminadas, numa segunda etapa, ocorre uma nova classificação e priorização de áreas onde são definidas as ASs, conforme segue abaixo.

\section{a. Avaliação Preliminar}

A avaliação preliminar é uma etapa do Sistema de Gerenciamento de Áreas Contaminadas onde o objetivo principal é obter informações específicas de cada local de interesse, definidas anteriormente como APs, através do preenchimento das Fichas Cadastrais (FCs). Em seguida, as informações obtidas nas FCs são transferidas para a Ficha de Pontuação (FP), que por sua vez, permitirá a classificação e priorização, definindo um novo universo no cadastro de áreas contaminadas, denominado de Áreas Suspeitas (ASs).

Assim, nesta etapa as APs, que são reconhecidas e caracterizadas simplesmente em função das atividades, passam por uma avaliação com base em informações de escritório e de campo específicas sobre a área. O levantamento das informações de campo consiste de visita à área para obter informações sobre a situação local e sua relação com os bens a proteger. Esta fase implica em baixos custos pois não há qualquer tipo de investigação "in situ" como perfuração, coleta de amostra e análise química. Baseia-se, principalmente, em análise visual e levantamento de informação existentes específicas da AP analisada.

\section{a.1. Ficha Cadastral (FC)}

A principal ferramenta desenvolvida para a Avaliação Preliminar é a Ficha Cadastral (FC) que segue no Anexo 1. A FC tem como objetivo principal registrar informações sobre a 
localização, características da fonte de contaminação, vias de propagação e a importância dos bens a proteger na área e no seu entorno.

Durante a visita à área, além do preenchimento da ficha cadastral, deve ser realizada a identificação e registro do local de interesse (ainda considerada como área potencial (AP)) em mapa de escala compatível conforme proposto no quadro 2, do ítem Definição da Região de Interesse e dos Bens a Proteger.

A FC é preenchida com as informações obtidas no escritório e na área, podendo, no entanto, sofrer atualizações, caso sejam geradas novas informações nas etapas subsequentes de avaliação confirmatória, de caracterização da área contaminada e remediação, ou a qualquer momento do processo.

\section{a.2. Ficha de Pontuação (FP)}

A base técnica da metodologia assenta-se no fato de que qualquer efeito adverso sobre $o$ meio ambiente e saúde humana provém de uma cadeia de eventos iniciando-se na fonte de contaminação e terminando no receptor.

Na Ficha de Pontuação (FP) é seguido fielmente o princípio da cadeia de eventos, valorando-se as várias etapas que a constituem, desde a fonte até o receptor. Assim, as etapas a serem consideradas são aquelas obtidas nas FCs que podem ser definidas como: características das fontes de contaminação, vias de propagação e a importâncias dos bens a proteger na área e no seu entorno (ANEXO 1).

Nestas três etapas são consideradas, não só a descrição da fonte de contaminação, como a descrição do meio-fisico tanto da área como das suas adjacências. Além disso, o sequenciamento das três etapas indica o provável caminho que a substância nociva pode tomar, sofrendo as suas reações bio-fisico-químicas durante o processo, até atingir os bens a proteger. Os bens a proteger incluem tanto os recursos naturais como as águas superficiais e subterrâneas, o solo e a vegetação, como também a saúde pública e áreas de interesse público presentes nas proximidades da área de disposição. 
b. Classificação das Áreas Potenciais

Nesta etapa, através da utilização das FCs e FPs é feita a classificação e priorização das áreas potenciais, reduzindo e definindo um novo universo de áreas denominadas Áreas Suspeitas (ASs).

Assim durante o processo de classificação, parte das áreas é priorizada e reclassificada como ASs, outra parte é mantida como APs e o restante, caso seja constatada a inexistência de fonte de contaminação, é excluído do Cadastro de Áreas Contaminadas. O critério de corte para reclassificação como ASs deve ser definido de acordo com a atividade contaminadora, vias de propagação e recursos ambientais e saúde pública.

Como resultado principal do processo de classificação das áreas potenciais obtém-se um universo menor de áreas (ASs), tendo como origem as APs.

\subsection{4. Áreas Contaminadas (ACs)}

A terceira etapa do gerenciamento de áreas contaminadas consiste na execução de Avaliação Confirmatória nas ASs. Esta avaliação deve ser iniciada nas áreas com pontuação mais alta, seguindo a ordem decrescente na pontuação. Se, por exemplo, um programa de gerenciamento de áreas contaminadas não dispor de recursos financeiros suficientes, pode-se priorizar somente aquelas áreas com pontuação mais alta correspondente ao montante de recursos disponiveis. As outras áreas restantes podem ser avaliadas em outro momento quando houver disponibilidade de novos recursos financeiros.

\section{a.1. Avaliação Confirmatória}

$\mathrm{Na}$ Avaliação Confirmatória deve ser feita uma investigação expedita "in situ" naquelas áreas priorizadas, onde havendo a confirmação de substâncias nocivas, elas passam a ser reclassificadas como ACs. A investigação objetivando a avaliação confirmatória pode ser efetuada por métodos diretos e indiretos.

Assim, o objetivo principal da Avaliação Confirmatória é certificar a presença de substâncias nocivas através de técnicas e metodologias consagradas cientificamente. As duas fases 
anteriores de classificação (APs e ASs), ao contrário da avaliação confirmatória, simplesmente permitem realizar uma avaliação a partir de informações cadastrais e descritivas existentes sobre a área em questão.

\section{a.2. Investigação de campo}

O intuito principal desta etapa é confirmar a presença de substâncias nocivas na área, nos meios: ar, água subterrânea, água superficial e solo. No quadro 3, encontram-se listados os quatro meios a serem investigados e os correspondentes tipos de investigação que podem ser realizados.

Quadro 3. Meios a serem investigados e tipos de investigação a serem executados.

\begin{tabular}{|l|l|}
\hline Meio a Ser Investigado & Tipo de Investigacão Rápida \\
\hline Ar do Solo & $\begin{array}{l}\text { Soil Gas Survey } \\
\text { Coleta e Análise de Gases }\end{array}$ \\
\hline Agua Subterrânea & $\begin{array}{l}\text { Investigação Geofísica } \\
\text { Coleta e Análise de Água } \\
\text { Subterrânea }\end{array}$ \\
\hline Agua Superficial & $\begin{array}{l}\text { Coleta e Análise de Água } \\
\text { Superficial na Área Suspeita }\end{array}$ \\
\hline Solo & $\begin{array}{l}\text { Coleta e Análise de Solo na Área } \\
\text { Suspeita }\end{array}$ \\
\hline
\end{tabular}

Por meio ar entende-se principalmente o ar existente nos interstícios da zona nãosaturada. Em muitas áreas onde são manipuladas substâncias voláteis, ou substâncias que geram um produto gasoso secundário, pode existir a propagação dos gases por difusão molecular através da zona não-saturada e colocar em risco a saúde da população, seja pelos efeitos diretos ou através de explosões.

Para detectar ou coletar estes gases na zona não-saturada, a técnica mais apropriada é o "Soil Gas Survey". Nos casos onde há a emanação de gases em edificações próximas são coletadas e analisadas amostras do ar contido nestas edificações.

$\mathrm{Na}$ água subterrânea em alguns casos podem ser utilizado métodos de investigação geofisica, tais como eletroresistividade, eletromagnético indutivo e radar de penetração. Estas técnicas devem ser utilizadas somente na detecção de substâncias que são comprovadamente sucetíveis de serem determinadas por método indireto, tais como: sais, metais pesados, etc. 
Em outros casos de avaliação confirmatória deve ser utilizada a coleta e análise da água subterrânea. Uma precaução deve ser tomada, a perfuração para a coleta de amostras de água deve ocorrer à jusante da fonte de contaminação de tal forma a atingir a água subterrânea contaminada.

$\mathrm{Na}$ água superficial, o procedimento é simples, a coleta deve ser feita à jusante do local de interesse. O maior problema nos cursos de água, é a probabilidade do corpo d' água superficial estar previamente contaminado. Neste caso, a análise da água superficial deve merecer maior detalhamento. As atividades potencialmente contaminantes a montante devem ser consideradas.

No solo, o procedimento também é simples, a coleta deve ser feita no solo potencialmente contaminado. Vale ressaltar que a definição da profundidade de amostragem é bastante importante.

\subsubsection{Caracterização das ACs}

$\mathrm{Na}$ etapa anterior, a presença da contaminação no local de interesse foi apenas confirmada através da investigação rápida. Assim, o objetivo principal da etapa de caracterização de ACs é definir e dimensionar a fonte de contaminação, assim como a área efetivamente contaminada nos meios solo, água superficial e subterrânea, e ar, considerando também os impactos nos bens a proteger.

Alguns aspectos importantes a serem incluídos na etapa de caracterização dizem respeito à determinação de características da fonte de contaminação, aplicando técnicas de investigação que permitam o reconhecimento de suas dimensões precisas, concentrações e tipos de contaminantes presentes. Da mesma forma, deve ser definida as características da pluma de contaminação ou área afetada pela contaminação gerada. Estes dados são fundamentais para a execução das etapas posteriores deste plano, que pode consistir de ações preventivas ou corretivas, como contenção ou remediação da área.

\subsubsection{Plano de Remediação de Áreas Contaminadas}

Após, a realização da caracterização das ACs, a etapa seguinte é a remediação. Além dos 
dados obtidos na etapa de caracterização das $\mathrm{ACs}$, o plano de recuperação deve considerar os seguintes ítens:

- a proteção da saúde humana e meio ambiente, com a análise de risco das atividades que serão desenvolvidas;

- as tecnologias conhecidas ou alternativas que tenham potencial para atingir o objetivo da recuperação;

- um cronograma da implantação e outro do tempo estimado para a recuperação;

- identificar todas as exigências especiais necessárias para provar a viabilidade técnica das ações corretivas;

- apresentar os métodos de destino final para os eventuais materiais contaminados que venham a ser removidos da área, como solo, água e entulhos, de acordo com a legislação específica;

- Contemplar a recuperação da fase livre, da fase dissolvida e da fase retida no solo. A não recuperação de qualquer uma das fases acima especificadas deve ser justificada;

- Definir os objetivos e limites a serem atingidos pelo sistema de recuperação;

- Avaliar periodicamente a eficiência da recuperação através do cálculo da remoção dos contaminantes e resultados analíticos do monitoramento.

- Apresentar memorial descritivo com respectiva memória de cálculo, mapa de localização, seções ilustrativas, bem como a identificação e registro do profissional responsável.

Caso o responsável pela contaminação não seja descoberto ou não possua condições financeiras para arcar com as despesas, no entanto a AC esteja representando um alto grau de risco aos bens a proteger, o órgão ambiental de controle deverá articular e viabilizar um fundo especial de remediação de áreas contaminadas para arcar com os custos de execução, que poderão ser repassados ao responsável pela contaminação caso este seja posteriormente identificado.

\subsection{Infraestrutura do Sistema de Gerenciamento de Áreas Contaminadas}

Para viabilizar a implementação da metodologia de gestão de áreas contaminadas discriminada acima é necessário organizar uma infraestrutura básica, conforme segue.

\subsubsection{Cadastro Informatizado}

As informações da Ficha Cadastral de Áreas Contaminadas referentes a Áreas Potenciais (APs), Áreas Suspeitas (ASs) e Áreas Contaminadas (ACs) devem ser armazenadas no cadastro informatizado através de banco de dados georeferenciados através de um Sistema Geográfico de Informações. 
As informações básicas a serem consideradas no cadastro informatizado sobre APs são:

- nome;

- localização;

- atividade.

Além dos dados de identificação acima, as informações a serem armazenadas, específicas sobre as ASs são:

- fontes suspeitas de contaminação;

- responsáveis pela contaminação;

- área/volume aproximado;

- contaminantes prováveis;

- bens a proteger;

- evidências de contaminação;

- vias de transporte dos contaminantes potenciais.

As informações a serem armazenadas, específicas sobre as ACs, além dos parâmetros acima mencionados são:

- forma de comprovação da contaminação;

- bens a proteger atingidos;

- vias de transporte dos contaminantes.

\subsubsection{Cadastro Físico}

Informações mais detalhadas, como por exempo o resultado da caracterização da área contaminada, relatórios, fotos aéreas, etc., sobre as APs, ASs, e ACs devem ser armazenadas em arquivos físicos

\subsubsection{Administração de Fundos e Legislação Específica}

A execução da caracterização e remediação das ACs implicam em custos. O órgão de controle e planejamento ambiental da região de interesse deve considerar a criação e administração de fundos destinados a este fim conforme estabelecido em legislações específicas como nos casos dos programas de áreas contaminadas nos E.U.A., Canadá, Alemanha, Holanda e outros países. 


\section{GESTÃo DE ÁREAS DE DISPOSIÇÃO DE RESÍDUOS SÓLIDOS PARA A RMSP}

O quadro do destino final de resíduos sólidos no Brasil é bastante caótico, sendo que $76 \%$ das áreas são consideradas como lixões. Do restante, $13 \%$ são aterros controlados, $10 \%$ aterros sanitários e $1 \%$ correspondem a áreas com compostagem e incineração. Na Região Metropolitana de São Paulo (RMSP), o quadro do destino final de residuos é igualmente caótico, mostrando-se bastante similar ao do restante do pais.

Neste contexto, observa-se que o número de áreas onde os resíduos são dispostos diretamente sobre o solo (lixões) predominam sobre as áreas de aterro. No contato direto entre o resíduo e o solo deve certamente haver a transferência de substâncias nocivas para o solo e água subterrânea. Dessa forma, a contaminação de recursos naturais torna-se evidente. Além disso, outros aspectos relativos à saúde pública também são claros, em função da existência de catadores nestas áreas. Este quadro indica uma necessidade imediata de ações governamentais para preservar e proteger estes recursos e a saúde da população.

Nos ítens seguintes são descritos os diferentes procedimentos que compõem a metodologia de gestão das área de disposição de resíduos sólidos na RMSP.

\subsection{Priorização de Áreas Potenciais}

Conforme apresentado anteriormente, no país apenas $1 \%$ dos resíduos sólidos não são dispostos sobre o solo na forma de lixões e aterros. Dessa forma, as áreas de disposição de resíduos, na maioria dos casos, não possuem obras de engenharia envolvendo impermeabilização superior e inferior, e a instalação de drenos de líquidos e de gases, o que torna a contaminação do solo, das águas superficiais e subterrâneas inevitável nestes locais. Tendo em vista o contexto e as circunstâncias mencionadas anteriormente, na RMSP, todas as áreas de disposição de resíduos sólidos são consideradas automaticamente áreas potenciais por dois motivos: primeiro, as áreas de lixões e aterros controlados transferem diretamente lixiviados e gases para a zona não-saturada e saturada, uma vez que não possuem sistemas de impermeabilização e drenos; segundo, nos aterros sanitários, há sempre o risco de rompimento da camada impermeabilizante e/ou drenos e transferência de substâncias nocivas como no primeiro caso. 


\subsection{Avaliação Preliminar}

Todas as áreas de disposição de resíduos consideradas Áreas Potenciais (APs) devem passar por uma avaliação preliminar, seguida de visita ao campo com o preenchimento da Ficha Cadastral e posterior uso da Ficha de Pontuação para a classificação dessas áreas. $O$ escopo das duas fichas estão descritos nos ítens que seguem.

\subsubsection{Ficha Cadastral e de Pontuação de Áreas Contaminadas}

O Sistema de Cadastramento e Pontuação para Classificação das Áreas Potenciais (APs) para Locais de Disposição de Resíduos Sólidos foi concebido considerando-se o baixo volume de informações e de conhecimentos disponiveis existentes no Brasil. Assim, para a classificação das APs elaborou-se um procedimento que permite uma apreciação com pouca informação, mas com resultado uniforme, conclusivo e amplo.

A concepção do Sistema de Cadastramento e Pontuação para a Classificação das APs apresentado no presente trabalho tem como base o sistema utilizado em Nordeheim-Westphalen denominado ISAL. A escolha deste sistema é devida à sua eficiência comprovada na Alemanha, também ao fato da metodologia não exigir parâmetros técnicos detalhados como o sistema dos E.U.A. Estes aspectos foram decisivos para a seleção de um sistema realístico e aplicável na RMSP.

Operacionalmente, o sistema constitui-se basicamente da Ficha Cadastral de Áreas Contaminadas cujas informações são utilizadas para a classificação das APs através da Ficha de Pontuação de Áreas Contaminadas.

a. Ficha Cadastral de Áreas Contaminadas

Para a elaboração da Ficha Cadastral de Áreas Contaminadas foi efetuada preliminarmente uma minuciosa pesquisa das fichas utilizadas no Canadá, E.U.A e Alemanha, em seus respectivos Programas de Áreas Contaminadas. Posteriormente, estas informações foram 
comparadas ao levantamento das informações necessárias para este projeto, elaborando-se uma primeira versão tentativa da Ficha Cadastral.

Esta primeira versão tentativa foi testada várias vêzes nas áreas de interesse, e no escritório para verificar a validade e a representatividade das informações nela contidas, até chegar-se à versão final apresentada no Anexo 1 .

Posteriormente, as informações das fichas foram compatibilizadas com aquelas necessárias para o preenchimento da Ficha de Pontuação de Áreas Contaminadas. Vale ressaltar que as fichas foram elaboradas de forma a considerar que, durante o, preenchimento ocorra um mínimo de subjetividade. Este fato é importante, na medida que permite garantir a confiabilidade e representatividade das informações, mesmo sendo preenchida por pessoas diferentes. Individualmente, a Ficha Cadastral de Áreas Contaminadas pode servir como instrumento de registro e consulta de informação da área de interesse. A Ficha Cadastral é um instrumento que permite registrar, através da observação em campo, de forma descritiva, rápida e genérica, 0 retrato atual das APs, permitindo uma posterior avaliação uniforme, rápida e de baixo custo, através da utilização da Ficha de Pontuação de Áreas Contaminadas.

Para o preenchimento da Ficha Cadastral não é necessário executar nenhum trabalho "in situ" (perfuração, levantamento geofísico, etc), portanto, o procedimento de preenchimento da ficha caracteriza-se como uma avaliação expedita no local de interesse, determinando-se os parâmetros que permitem a descrição da área apenas por visualização e por sistematização das informações existentes.

A Ficha Cadastral de Áreas Contaminadas, no que concerne às áreas de disposição de resíduos sólidos, é composta basicamente de 5 tópicos de coleta de informação: Identificação da Área, Forma de Disposição de Resíduos, Descrição da Área e suas Adjacências, Eventos Importantes e Atividades Desenvolvidas na Área.

\section{a.1. Identificação da Área}

As informações básicas que constam neste ítem objetivam a identificação do local de interesse e outros dados básicos, conforme apresentado no quadro 4. 
Quadro 4. Quadro contendo informações sobre Identificação da Área

\begin{tabular}{|c|c|}
\hline Tópicos & Tipo de Informacão \\
\hline Identificação & $\begin{array}{l}\text { - } N^{\circ} \text { de Cadastro } \\
\text { - } \text { Resta de visita } \\
\text { - Renonsável pela coleta da informação } \\
\text { - Endereça } \\
\text { - Coordenadas atual do local } \\
\text { - Proprietário }\end{array}$ \\
\hline Informaç̃es Básicas & $\begin{array}{l}\text { - Situação atual quanto ao funcionamento } \\
\text { - Área total } \\
\text { - Classificação da área } \\
\text { - Tipo de fonte de contaminação }\end{array}$ \\
\hline
\end{tabular}

As informações referentes à identificação que constam no quadro acima têm como objetivo básico a fácil identificação do local e do proprietário da área, seja através dos sistemas tradicionais de identificação, conforme exigido pelos governos municipais, estaduais e federais, seja pelo sistema cartográfico utilizado nos meios científicos.

Quanto ao quadro das informações básicas são considerados vários aspectos. A área do local de deposição pode ser caracterizada como um pequeno local, como pode possuir porte médio a grande, podendo estar em funcionamento ou desativada.

Quanto à classificação da área, o objetivo básico é identificar, dentro do conceito de gerenciamento de áreas contaminadas, se o local de interesse deve ser classificado como área potencial, área suspeita ou área contaminada.

\section{a.2. Forma de Disposição de Resíduos}

$\mathrm{Na}$ Ficha Cadastral, como forma de disposição de resíduos encontram-se contemplados os seguintes tópicos: tipo e forma de disposição, aspectos operacionais e construtivos do local de disposição, líquidos percolados e existência de catadores no local, conforme segue no quadro 5 . 
Quadro 5. Quadro com informações sobre a forma de disposição de residuos

\begin{tabular}{|c|c|}
\hline Tópicos & Tipos de Informação \\
\hline Tipo e forma de disposição & $\begin{array}{l}\text { - Tipo de disposição } \\
\text { - Volume } \\
\text { - Tipo de resíduos } \\
\text { - Profundidade da disposiçáo }\end{array}$ \\
\hline $\begin{array}{l}\text { Aspectos operacionais e construtivos do local de } \\
\text { disposição }\end{array}$ & $\begin{array}{l}\text { - Impermeabilização } \\
\text { - Recobrimento operacional } \\
\text { - Compactação } \\
\text { - Drenagens } \\
\end{array}$ \\
\hline Líquidos percolados & $\begin{array}{l}\text { - Destino dos líquidos percolados } \\
\text { - Tipo de sistema de tratamento de líquidos } \\
\text { percolados }\end{array}$ \\
\hline Catadores no local & - Existência de catadores no local \\
\hline
\end{tabular}

$\mathrm{Na}$ ficha estão relacionados aspectos como o tipo de disposição, o que inclui a forma de disposição, a quantidade e o tipo de resíduo. As formas de disposição abrangidas são: aterro controlado, aterro industrial, aterro sanitário, aterro de entulhos, lixão e bota fora.

No atributo da quantidade são incluídos parâmetros como volume e também o peso. $\mathrm{Na}$ realidade, estes dois aspectos devem ser considerados porque existem locais que possuem controle através de balança e outros onde somente é possivel estimar o volume.

Tendo sido definida a forma de disposição, o passo seguinte é a caracterização dos tipos de resíduo quanto a sua origem: resíduo industrial, resíduo domiciliar, resíduo de mineração, residuo de serviço de saúde, resíduo inerte, lodos de tratamento de águas residuárias, lodos de dragagem, resíduos de varrição, entulhos e outros lodos.

Outro aspecto considerado é a posição do local de disposição em relação a superfície do terreno (abaixo ou acima). Este aspecto é avaliado visando principalmente a proximidade da posição do local de disposição em relação à profundidade do lençol freático.

Em relação aos aspectos construtivos, são considerados vários ítens. Inicialmente, a existência de impermeabilização inferior e o tipo utilizado: argila, membrana, dupla membrana. Em seguida, a possível existência de drenagens de água de escoamento superficial, de líquidos percolados, de nascentes e de gases. Além disso, na operação do local de deposição é considerado o fator compactação e o recobrimento diário do resíduo.

Quanto aos líquidos percolados são analisadas várias possibilidades de destino final, entre outros: água superficial, infiltração no solo ou em poços, estação de tratamento de esgotos e estação de tratamento no local. Além disso, quando há tratamento dos líquidos no local, deve ser 
avaliado se ele é feito através de lagoas com impermeabilização, filtros, digestor anaeróbico ou recirculação.

Como é comum a presença de catadores nos lixões da RMSP, tentando aproveitar produtos recicláveis existentes na massa de lixo, na ficha é identificado o número de pessoas existentes para poder avaliar o risco à saúde.

\section{a.3. Descrição da Área e Suas Adjacências}

Neste ítem encontram-se contempladas as substâncias químicas possíveis de serem encontradas na massa de lixo, e também as informações relativas aos recursos ambientais solo, água superficial, água subterrânea e vegetação, e também as áreas de interesse público. No ítem são relacionados também aspectos referentes à propagação das substâncias nocivas através do solo, ar, água superficial e água subterrânea (QUADRO 6).

Os locais de disposição de resíduos sólidos na RMSP normalmente possuem na sua massa tanto materiais de origem doméstica quanto industrial. Estes materiais sofrem reações químicas ao longo do tempo e podem gerar líquidos perigosos que podem conter na sua composição, desde solventes orgânicos halogenados até metais pesados. Assim, entre muitas substâncias manipuladas pelo homem, os principais grupos que podem estar presentes no líquido são: solventes orgânicos, hidrocarbonetos (clorados, aromáticos e policíclicos), dioxinas e furanos, compostos orgânicos nitrogenados, fosfatados e sulfurados, derivados de petróleo, alcatrão e similares, pesticidas, metais, compostos inorgânicos, ácidos, bases e anidridos.

A avaliação da ocupação do solo e de áreas com bens a proteger são importantes porque eles serão os elementos atingidos pela contaminação, que por sua vez, podem atingir o homem tanto através da exposição direta ao contaminante, como indiretamente ingerindo água ou alimentos contaminados. Além disso, os contaminantes podem deteriorar o padrão e a qualidade das áreas de interesse público.

Vale ressaltar que, a avaliação do solo apresentada na ficha, permite a compreensão de aspectos relacionados à textura do solo (argilosa, siltosa ou arenosa), que por sua vez, está diretamente ligada à questão da vulnerabilidade do aquífero. Segundo HIRATA (1994), o solo e a zona vadosa representam a primeira e mais importante defesa natural contra a poluição de aquíferos. Este fato é devido não somente à sua posição estratégica, situada entre a superficie e a 
Quadro 6. Informações sobre descrição da área de disposição de resíduos e áreas adjacentes

\begin{tabular}{|c|c|}
\hline Tópicos & Tipos de Informaçóes \\
\hline Resíduos e/ou substáncias presentes na área & $\begin{array}{l}\text { - Solventes orgânicos } \\
\text { - Hidrocarbonetos clorados, aromáticos e } \\
\text { policiclicos } \\
\text { - Dioxinas e furanos } \\
\text { - } \text { somp. org. nitrogenados, fosfatados e } \\
\text { - Derivados } \\
\text { - Alcatráo e similares } \\
\text { - Pesticidas } \\
\text { - Acidos, bases e anidridos } \\
\text { - Metais e compostos metálicos } \\
\text { - Compostos inorgânicos } \\
\end{array}$ \\
\hline Ocupaçăo do solo/áreas com bens a proteger & $\begin{array}{l}\text { - Ocupaçăo do solo urbano } \\
\text { - Zonas viárias } \\
\text { - Areas agropastoris } \\
\text { - Areas de proteçăo ambiental } \\
\text { - Areas de proteção de manancial } \\
\text { - Aquiferos importantes } \\
\text { - Posiçáo da área no relevo }\end{array}$ \\
\hline Solo & $\begin{array}{l}\text { - Textura predominante do solo } \\
\text { - Análise do solo }\end{array}$ \\
\hline Agua subterránea & $\begin{array}{l}\text { - Profundidade do nivel d'água } \\
\text { - Qualidade de água } \\
\text { - Uso da água subterrânea } \\
\text { - Contexto hidrogeológico }\end{array}$ \\
\hline Agua superficial & $\begin{array}{l}\text { - Proximidade do local de disposição em } \\
\text { relação à água superficial } \\
\text { - Qualidade da água superficial } \\
\text { - Uso da água superficial } \\
\end{array}$ \\
\hline $\operatorname{Ar}$ & - Qualidade do ar inclusive no solo \\
\hline
\end{tabular}


água subterrânea, mas também pelo seu ambiente fisico-bioquímico, que geralmente é mais favorável à eliminação e à atenuação de poluentes. O levantamento de análises químicas do solo, previamente existentes, pode auxiliar na identificação da qualidade do solo.

A água subterrânea ocorre na zona imediatamente abaixo da zona não-saturada e é considerada como um recurso estratégico para o abastecimento público. Para a substância derivada do local de disposição atingir este recurso é necessário percorrer toda a zona nãosaturada. Dessa forma, para avaliar a possibilidade de ocorrer a contaminação do lençol freático é necessário observar dois aspectos: a composição granulométrica da zona não-saturada e a sua espessura. A questão da composição granulométrica está contemplada na avaliação do solo e a espessura da zona não-saturada pode ser obtida estimando-se a profundidade do lençol freático. Assim como no caso do solo, a qualidade da água subterrânea pode ser avaliada através do levantamento das análises químicas já existentes.

Outros aspectos relacionados à água subterrânea são o seu uso e o contexto hidrogeológico em que o local de disposição está inserido. Na questão do uso, a água subterrânea existente nas adjacências do local de disposição pode ter diferentes fins como irrigação, pecuária, piscicultura, recreação, abastecimento público e uso industrial. Quanto ao contexto hidrogeológico existem dois aspectos importantes: o tipo de aquífero e a forma de circulação das águas subterrâneas. Na RMSP, ocorrem alguns tipos de aqufferos mais susceptíveis à contaminação, tais como aquífero cárstico, sedimentar e cristalino com manto arenoso. Por outro lado, existem outros tipos de aquíferos como o cristalino ou sedimentar, com manto argiloso, menos susceptíveis à contaminação. A este conceito está intimamente associada a forma de circulação das águas subterrâneas, isto é, as áreas de recarga são mais susceptíveis à contaminação que as áreas de descarga.

Na propagação através das águas superficiais, qualquer substância química proveniente do local de disposição pode ter duas origens. A primeira é a transferência direta do lixiviado para o corpo hídrico superficial e o segundo é a transferência indireta através da descarga da água subterrânea, que sofreu anteriormente contaminação no local da disposição. $O$ caminho através das águas subterrâneas foi avaliado e discutido no parágrafo anterior. Para a transferência direta deve ser avaliada inicialmente a questão da distância do local da disposição em relação ao corpo hídrico superficial. Além disso, para determinar se o corpo hídrico está contaminado ou não, deve ser realizado um levantamento de análises químicas existentes. O uso da água superficial na área 
adjacente ao local de disposição também deve ser considerado, assim como para a água subterrânea.

A propagação via ar refere-se principalmente ao ar que migra através da zona nãosaturada. Isto porque os gases gerados no processo de decomposição do material existente no local de disposição, são fortemente susceptíveis às explosões, causando acidentes e colocando em risco a população existente no local e nas áreas adjacentes.

\section{a.4. Eventos Importantes/Riscos Comprovados}

Muitos dos eventos e indicações observadas no solo ou na superficie podem indicar uma provável presença de contaminação, ou caminho preferencial, para a contaminação da zona nãosaturada e saturada, ou ainda, provável indicação de prejuízo à saúde da população (QUADRO 7).

Quadro 7. Informações sobre eventos importantes ocorridos na área de disposição de resíduos

\begin{tabular}{|l|l|}
\hline \multicolumn{1}{|c|}{ Tópicos } & \multicolumn{1}{c|}{ Típos de Informaçães } \\
\hline Eventos & $\bullet$ recalque \\
& $\bullet$ desabamento \\
$\bullet$ & danos à vegetação, animais e saúde humana \\
& explosão, incêndio \\
\hline Indicações no Solo & $\bullet$ erosão \\
& $\bullet$ escoamento de chorume no solo \\
& $\bullet$ gases/vapores nas edificações \\
\hline
\end{tabular}

O recalque ou desabamento da área de interesse, seja no aterro ou nas suas adjacências, indicam a presença de movimentação diferencial da massa de material (solo, rocha, resíduo, etc), que muitas vêzes pode redundar em danos nas obras de engenharia, como rompimentos de drenos, mantas, selos e coberturas. Estes processos de movimentação de massa acabam acarretando aberturas de fraturas que podem ocasionar fluxos preferenciais das águas de percolação e/ou lixiviado.

O processo de erosão pode favorecer o transporte de resíduos, ou mesmo do lixiviado, através do escoamento das águas superficiais.

Muitos dos danos causados à vegetação ou à saúde de animais e humana, ocorrem como consequência da difusão de gases, transferência de lixiviados, dispersão de poeira e veiculação de doenças. 
Fatos como geração de gases são indicações de riscos para a saúde e vida da população no local de disposição e suas adjacências. Os gases gerados na massa de resíduos podem migrar para as áreas adjacentes da área de disposição e causar danos tanto à vida humana e animais quanto às edificações, através de explosões, incêndios e intoxicações.

\section{a.5. Atividades Desenvolvidas na Área}

Na Ficha Cadastral, na sua última página, existe um ítem onde pretende-se obter um registro rápido a cerca da situação atual na qual se encontra cada área de disposição. segundo a concepção do Sistema de Gerenciamento de Áreas Contaminadas. Na realidade, nesta página da ficha ficam registradas, de forma sintética, as atividades que foram desenvoldidas: avaliação confirmatória, caracterização da área, monitoramento e remediação do local, conforme observa-se no quadro 8 e descrito na parte 2 , desta tese.

Quadro 8. Resumo sobre atividades de gerenciamento de áreas de disposição de resíduos sólidos a serem desenvolvidas

\begin{tabular}{|l|l|}
\hline \multicolumn{1}{|c|}{ Tópicos } & \multicolumn{1}{|c|}{ Tipos de Atividades } \\
\hline Atividades desenvolvidas & Avaliação Preliminar \\
& - Avaliação Confirmatória \\
& - Caracterização da Área \\
& Monitoramento \\
& - Remediação do Local \\
\hline
\end{tabular}

b. Ficha de Pontuação de Áreas Contaminadas

b.1. Conceituação técnica

Conforme descrito anteriormente, a base técnica da metodologia encontra-se no fato de que qualquer efeito adverso sobre o meio ambiente e saúde humana provém de uma cadeia de eventos iniciando-se na fonte de contaminação e terminando no receptor.

Dessa forma, a concepção básica do sistema elaborado é de que a área de disposição de resíduos, em princípio, pode conter substâncias nocivas que põem em risco a qualidade dos recursos ambientais e a saúde pública. Estas substâncias podem apresentar seus efeitos prejudiciais 
somente quando entram em contato com o recurso. Assim, na averiguação do risco para os recursos ambientais e saúde pública são consideradas três etapas.

(1) Origem e volume de resíduos, e tipos de grupos de substâncias possiveis de serem encontradas no local da disposição;

(2) Propagação das substâncias nocivas através dos meios ar, solo, água superficial e água subterrânea;

(3) Existência de bens a proteger na área de disposição e/ou nas adjacências.

Na primeira etapa é realizada a caracterização da massa de lixo quanto a sua origem, volume e tipo de grupo de substâncias, onde cada uma delas é classificada respectivamente em três categorias de acordo com a sua periculosidade, tamanho e toxicidade.

Na segunda etapa são avaliados os prováveis caminhos que a substância originária da massa de lixo pode tomar através do meio ar, solo, água superficial e subterrânea. No meio ar, inicialmente são considerados apenas os componentes gasosos que estão presentes na zona nãosaturada e que podem receber uma contribuição (principalmente do gás metano originário da decomposição de matéria orgânica). Os componentes gasosos ao difundirem em subsuperficie podem atingir os bens a proteger e causar danos materiais e à vida, através de acidentes e/ou intoxicação.

$\mathrm{Na}$ terceira etapa é feita a análise dos efeitos que as substâncias causam aos bens a proteger, que basicamente são os recursos naturais e a saúde pública.

A entrada da substância significa a exposição do recurso à ela e a sua liberação é a condição necessária para que se tenha a exposição do recurso.

\section{b.2. Formato da Ficha de Pontuação}

O sistema de pontuação apresentado neste trabalho caracteriza-se por ser um método numérico, ponderado e cumulativo. Dessa forma, a avaliação de um local suspeito ou contaminado é feita em vários módulos seguindo sucessivamente as três etapas apresentadas no ítem anterior.

As informações sobre a fonte de contaminação, origem e volume de resíduos, e tipos de grupos de substâncias possíveis de serem encontrados no local da disposição, são avaliadas partindo-se do pressuposto da existência de periculosidade no local. Em seguida são avaliados os 
vários caminhos que a substância nociva e/ou seus derivados podem seguir através do ar, solo, água superficial e água subterrânea. Por fim efetua-se a análise da existência de bens a proteger na área de disposição e/ou nas suas adjacências, que podem ser prejudicados ou danificados pelos efeitos das substâncias originárias do local de disposição.

Dessa forma partindo-se de existência da periculosidade de uma substância que resulta do estabelecimento de uma situação padronizada de uma atividade ou local, elas podem ser avaliadas em três etapas distintas, a periculosidade do local de disposição (a), a propagação (b) e os efeitos sobre os bens a proteger(c).

$\mathrm{Na}$ prática, cada um dos componentes de risco é composto por um parâmetro que representa uma ação ou fato $(\mathrm{Rn})$, que por sua vez, é multiplicado por um fator de minimização ou de agravamento do risco, expresso através de multiplicadores $(\mathrm{Mn})$. Os parâmetros Rn e Mn são classificados em três categorias que são: alto (3), médio (2) e baixo (1). Assim a avaliação do risco do local de interesse é calculada segundo a formula e o quadro 9.

$$
\mathrm{R}=(\mathrm{MI} . \mathrm{RI}) \times(\mathrm{MII} . \mathrm{RII}) \times(\mathrm{MIII} . \mathrm{RIII})=R a \times R b \times R c
$$

Quadro 9. Resumo sobre etapas do Sistema de Pontuação

\section{SISTEMA DE PONTUAC̄̃̃O}

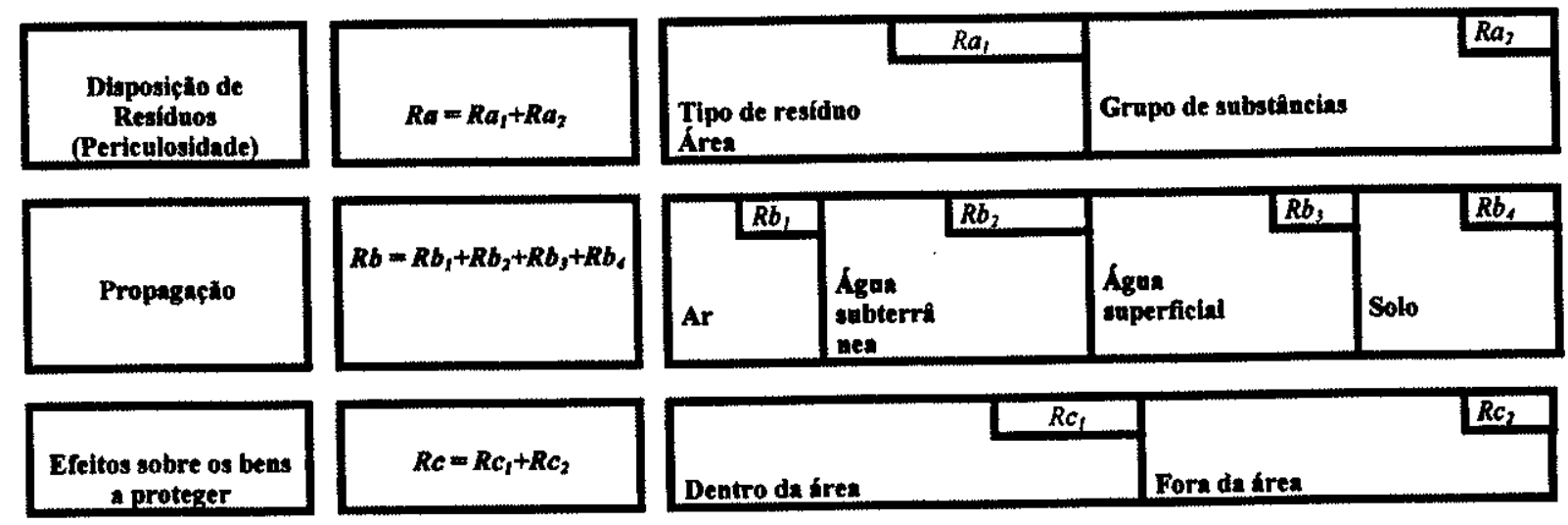




\section{b.2.1. Periculosidade do local de disposição}

Conforme apresentado no quadro acima, o risco $R a$ que considera a periculosidade do local de disposição é composto por componentes $R a_{1}$ e $R a_{2}$, onde o primeiro componente considera o tipo de resíduo e o volume de residuos do local de disposição, e o segundo, o grupo de substâncias que pode ser encontrado no local. Para os componentes $R a_{1}$ e $R a_{2}$, os valores de Rn e Mn são conforme apresentados nos quadros 10 e 11 .

Dessa forma, inicialmente são considerados o tipo de resíduo existente na massa de lixo e o seu volume. $O$ valor mais alto é atribuído ao local de disposição que apresentar alta toxicidade e/ou grande volume (QUADRO 10). Os tipos de resíduos considerados no quadro acima, são classificados, de uma forma genérica em, domiciliar, hospitalar, industrial, mineração, inerte e outros, de acordo com a sua origem.

Quadro 10. Valores de Rn e Mn para o componente $R a_{i}$

\begin{tabular}{|l|c|c|}
\hline \multicolumn{1}{|c|}{ Disposição: Típos de Residuos } & Mn & Rn \\
\hline Residuo Industrial & 1,90 & 3 \\
\hline Resíduo de Serviço de Saúde & 1,90 & 3 \\
\hline Residuo Domiciliar & 1,90 & 2 \\
\hline Residuo Inerte & 1,90 & 1 \\
\hline Resíduo de Mineraç̃o & 1,90 & 1 \\
\hline Varrição & 1,90 & 1 \\
\hline Entulhos & 1,90 & 1 \\
\hline Lodos do Tratamento de Aguas Residuárias & 1,90 & 2 \\
\hline Lodos de Dragagem & 1,90 & 3 \\
\hline Outros Lodos & 1,90 & 3 \\
\hline \multicolumn{1}{|c|}{ Volume de Disposição de Resíduos } & & \\
\hline$>1.000 .000 \mathrm{~m}^{3}$ & 0,48 & 3 \\
\hline $100.000-1.000 .000 \mathrm{~m}^{3}$ & 0,48 & 2 \\
\hline$<100.000 \mathrm{~m}^{3}$ & 0,48 & 1 \\
\hline
\end{tabular}

Por outro lado, em muitos locais de disposição, os resíduos encontram-se misturados e possuem na maioria dos casos origens bastante variadas. Nesta situação, apenas o caso de maior valor é considerado para a questão da pontuação. Assim, o sistema de pontuação é eliminatório, considerando-se apenas a pior situação ou de maior risco.

O volume de resíduo do local de disposição também deve ser considerado. Normalmente, locais de disposição com volume pequeno estão associados a municípios pequenos, que geralmente possuem na massa de lixo resíduos domésticos. Ao contrário, locais de disposição com 
Quadro 11. Valores de Rn e Mn para o componente $R a_{2}$

\begin{tabular}{|c|c|c|c|}
\hline Grupos de Substâncias & $\mathbf{M n}$ & $\begin{array}{c}\mathbf{R n} \\
\text { (Confirmado) }\end{array}$ & $\begin{array}{c}\text { Rn } \\
\text { (Estimado) }\end{array}$ \\
\hline Orgânicos halogenados voláteis & 0,95 & 3 & 2 \\
\hline Orgânicos nåo halogenados voláteis & 0,95 & 3 & 2 \\
\hline Hidrocarbonetos clorados voláteis & 0,95 & 3 & 2 \\
\hline Aromáticos Clorados (PCB) & 0,95 & 3 & 2 \\
\hline Dioxinas e Furanos & 0,95 & 3 & 2 \\
\hline $\begin{array}{l}\text { Compostos org. Nitrogenados, Fosfatados, } \\
\text { Sulfados (sem Pesticidas) }\end{array}$ & 0,95 & 3 & 2 \\
\hline Hidrocarbonetos aromáticos (sem PAH) & 0,95 & 3 & 2 \\
\hline $\begin{array}{l}\text { Hidrocarbonetos Policíclicos Aromáticos } \\
\text { (PAH) }\end{array}$ & 0,95 & 3 & 2 \\
\hline Fenóis & 0,95 & 3 & 2 \\
\hline Derivados de petróleo & 0,95 & 2 & 1 \\
\hline Alcatróes e produtos similares & 0,95 & 2 & 1 \\
\hline \multirow[t]{2}{*}{ Pesticidas } & 0,95 & 3 & 2 \\
\hline & 0,95 & & \\
\hline Metais e seus compostos & 0,95 & 3 & 2 \\
\hline Compostos inorg. (sem metais) & 0,95 & 2 & 1 \\
\hline \multirow[t]{2}{*}{$\begin{array}{l}\text { Compostos inorg .(mais tóxicos: Cianetados, } \\
\text { fluorados e cromados) }\end{array}$} & 0,95 & 3 & 2 \\
\hline & 0,95 & & \\
\hline outras substancias & 0,95 & 2 & 1 \\
\hline desconhecida & 0,95 & 1 & 1 \\
\hline
\end{tabular}


volume grande estão associados a municípios grandes, que possuem atividades bastante variadas, que por sua vez, geram resíduos de várias origens com toxicidade alta.

A periculosidade do local de disposição é ainda avaliada através da pontuação por grupo de substâncias. No quadro 11 apresenta-se a classificação, também de forma genérica, da possivel constituição da massa de lixo, em grupos de substâncias. No quadro, observa-se que os grupos que possuem valores mais altos são substâncias bastante persistentes e tóxicas quando introduzidas nos recursos ambientais. Vale ressaltar que, estão listados no quadro 11 tanto os compostos orgânicos quanto os inorgânicos. Estes últimos, principalmente representados pelos metais pesados e compostos nitrogenados.

$\mathrm{Na}$ pontuação apresentada nos quadros 10 e 11 , está implícito o conceito de periculosidade de um resíduo/substância, onde são levado em consideração principalmente fatores como:

- características de toxicidade humana e ambiental;

- possibilidades de bioacumulação;

- concentração e distribuição;

- solubilidade, lixiviabilidade, miscibilidade;

- estado de agregação, estrutura, densidade e viscosidade;

- mobilidade, estabilidade, volatilidade;

- reatividade com a água;

- alterações possíveis com o tempo;

\section{b.2.2. Propagação}

O risco $R b$ que avalia o risco de propagação das substâncias nocivas é constituído pelos componentes $R b_{1}, R b_{2}, R b_{3}$ e $R b_{4}$, que correspondem respectivamente à avaliação da possibilidade de propagação nos meios ar, água subterrânea, água superficial e solo. Para os componentes $R b_{l}$, $R b_{2}, R b_{3}$ e $R b_{4}$, os valores de Rn e Mn são conforme apresentados nos quadros $12,13,14$ e 15.

\section{b.2.2.1. $\mathrm{Ar}$}

Para a avaliação da propagação via ar, de substâncias nocivas a partir do local de disposição, podem ser distinguidos quatro caminhos preferenciais.

- ar livre diretamente sobre o local contaminado;

- ar livre nos arredores do local contaminado; 
- ar nos poros do solo;

- ar existente nos ambientes fechados no solo ou sobre o solo (porões, clarabóias, etc)

Quando ocorre a produção de gás e a sua consequente liberação no interior de um local contaminado, este se propaga em virtude da alta pressão que ocorre. Com isso, o ar sobre o local e o ar do solo contido no entorno do foco de risco podem ser diretamente prejudicados. No caso de substâncias nocivas formadoras de gás é importante também a liberação propiciada pela difusão. Ainda, o gás liberado, especialmente quando gerado em grandes quantidades, pode funcionar como gás de arraste para outros, que caso contrário, teriam dificuldades para deixar as proximidades do foco de risco. Por exemplo, substâncias traços existentes na composição do gás do local de disposição, como hidrocarbonetos halogenados e ácidos orgânicos de baixo peso molecular podem ser carreados em conjunto com gás metano.

Os fatores que permitem o transporte do gás liberado até o recurso ambiental a proteger são os listados abaixo.

- possibilidade de escape (poros, fendas, frestas, canalizações, divisão do subsolo em camadas, passagens de tubulações);

- elementos de separação (camadas de argila, corpos d'água);

- condições de corrente (diferença de pressão e temperatura, etc);

- meios de transporte de gases nocivos (por exemplo, gás de aterro para gases traço);

- alterações de concentração.

Os fatores acima discriminados estão implicitamente inclusos no sistema de pontuação apresentado no quadro 12 .

\section{b.2.2.2. Águas subterrâneas}

A água, por si só, tem uma grande importância na maioria dos processos de reações químicas existentes na face da Terra, agindo como um solvente universal. No caso da propagação de substâncias nocivas, a água subterrânea possui o mesmo grau de importância e funciona como um dos principais meios de entrada e transporte de substâncias perigosas para diversos recursos ambientais. Dessa forma, sob o ponto de vista da água subterrânea, os seguintes fatores característicos da situação de disposição são significativos para a liberação da substância nociva:

- impermeabilização superficial, cobertura intermediária (tipo, qualidade, cobertura vegetạl, etc);

- escoamento de águas superficiais (configurações da superficie, declividade, drenagem da água, tipo e condições dos canais); 
Quadro 12. Valores de Rn e Mn para o componente $R b_{1}$

\begin{tabular}{|l|c|c|}
\hline \multicolumn{1}{|c|}{ Qualidade do ar do solo } & Mn & Rn \\
\hline Análise não realizada & 0,3 & 2 \\
\hline Contaminada & 0,3 & 3 \\
\hline Não contaminada & 0,3 & 0 \\
\hline Desconhecida & 0,3 & 2 \\
\hline \multicolumn{1}{|c|}{ Eventos importantes } & & \\
\hline explosão, incêndios, danos à saúde & 0,4 & 3 \\
\hline $\begin{array}{l}\text { emanação perceptivel de gases/vapores, } \\
\text { dispersão de poeira contaminada }\end{array}$ & 0,4 & 2 \\
\hline danos materiais, outros & 0,4 & 2 \\
\hline danos à vegetação & 0,4 & 2 \\
\hline inexistente & 0,4 & 0 \\
\hline \multicolumn{1}{|c|}{ Presença de vapores/gases nas } & & \\
\hline \multicolumn{1}{|c|}{ edificações vizinhas } & & 0 \\
\hline Não & 0,4 & 3 \\
\hline Sim & 0,4 & 1 \\
\hline Desconhecido & 0,4 & \\
\hline Distância até a edificação mais próxima & & 3 \\
\hline$<50 \mathrm{~m}$ & 0,4 & 2 \\
\hline $50-100 \mathrm{~m}$ & 0,4 & 1 \\
\hline$>100 \mathrm{~m}$ & 0,4 & 0 \\
\hline edificações inexistentes & 0,4 & \\
\hline
\end{tabular}


- adições de água (águas de encosta, fontes);

- clima (quantidade de chuvas, taxa de evaporação);

- impermeabilização do fundo (material, declividade)

- drenagem do fundo ou de camadas intermediárias compactadas (perfil do fundo, distâncias, pressões hidrostáticas, diâmetro e inclinação de canalizações de drenagem);

- existência e durabilidade de impermeabilizações;

Após a liberação, a entrada da substância nociva no recurso ambiental "água subterrânea" é contabilizada somente quando a sua quantidade excede os padrões de potabilidade para o consumo humano. Assim, os seguintes fatores relacionados ao subsolo são importantes para a entrada de substância nociva:

- estrutura e principalmente a uniformidade do subsolo (porosidade, permeabilidade, fissuras, granulometria);

- profundidade ou distância da água subterrânea à fonte de substância nociva;

- propriedades físico-químicas (composição mineral, umidade do solo, $\mathrm{pH}$, potencial Redox, CTC, teor de argila, tipo e quantidade de substâncias orgânicas, propriedades de sorção);

- temperatura;

- vida no solo (microorganismos)

Os fatores acima listados estão implícitos e inclusos no sistema de pontuação do quadro 13.

\section{b.2.2.3. Águas superficiais}

Assim como no recurso ambiental água subterrânea, na água superficial a característica da reatividade da própria água tem um papel importantíssimo no processo de liberação, entrada e transporte de substâncias nocivas.

No caso da avaliação de liberação de substâncias nocivas do resíduo e potencial de propagação via água superficial, os seguintes fatores são importantes.

- impermeabilização superficial e intermediária;

- condições topográficas (cota do foco de risco em relação ao terreno);

- adições de água (entradas de água de encosta e fontes);

- clima (chuvas, taxa de evaporação);

- drenagem de fundo ou de camadas intermediárias compactadas;

- tipo de enchimento (camadas intermediárias, construção das células, material de recobrimento, etc);

- quantidade de substância nociva. 
Quadro 13. Valores de $R n$ e Mn para o componente $R b_{2}$

\begin{tabular}{|c|c|c|}
\hline Contaminação das águas subterrâneas & Mn & $\mathbf{R n}$ \\
\hline Sim, contaminada & 0,5 & 3 \\
\hline Não & 0,5 & 0 \\
\hline desconhecida & 0,5 & 2 \\
\hline \multicolumn{3}{|l|}{$\begin{array}{l}\text { Uso da água subterrânea afetada pela } \\
\text { contaminação }\end{array}$} \\
\hline Abastecimento público & 0,4 & 3 \\
\hline Abastecimento domiciliar & 0,4 & 3 \\
\hline Recreação & 0,4 & 3 \\
\hline Irrigação, pecuária & 0,4 & 2 \\
\hline Uso industrial & 0,4 & 1 \\
\hline Desconhecida & 0,4 & 2 \\
\hline Inexistente & 0,4 & 0 \\
\hline \multicolumn{3}{|l|}{ Textura predominante do solo } \\
\hline arenosa, siltosa & 0,1 & 3 \\
\hline argilosa & 0,1 & 0 \\
\hline desconhecida & 0,1 & 2 \\
\hline \multicolumn{3}{|l|}{ Impermeabilização inferior } \\
\hline inexistente, outros, desconhecida & 0,2 & 3 \\
\hline argila ou membrana & 0,2 & 1 \\
\hline argila e membrana, dupla membrana & 0,2 & 0 \\
\hline \multicolumn{3}{|l|}{$\begin{array}{c}\text { Destino final de líquidos percolados, } \\
\text { efluentes, substâncias e materiais }\end{array}$} \\
\hline $\begin{array}{l}\text { água superficial, infiltração no solo ou } \\
\text { poços }\end{array}$ & 0,2 & 3 \\
\hline estação de tratamento & 0,2 & 0 \\
\hline \multicolumn{3}{|l|}{$\begin{array}{l}\text { Nivel sazonalmente mais elevado d'água } \\
\text { subterrânea }\end{array}$} \\
\hline em contato com resíduo/solo contaminado & 0,1 & 3 \\
\hline abaixo dos resíduos/solo contaminado & 0,1 & 0 \\
\hline desconhecida & 0,1 & 2 \\
\hline \multicolumn{3}{|l|}{ Contexto hidrogeológico } \\
\hline $\begin{array}{l}\text { Quaternário, Terciário em área de recarga, } \\
\text { Cárstico, Cristalino aflorante, Cristalino } \\
\text { com manto arenoso em área de recarga. }\end{array}$ & 0,4 & 3 \\
\hline $\begin{array}{l}\text { Terciário em área de descarga, cristalino } \\
\text { com manto argiloso em área de recarga, } \\
\text { cristalino com manto arenoso em área de } \\
\text { descarga. }\end{array}$ & $\overline{0,4}$ & 2 \\
\hline $\begin{array}{l}\text { Cristalino com manto argiloso em área de } \\
\text { descarga }\end{array}$ & 0,4 & 1 \\
\hline desconhecido & $\overline{0,4}$ & 3 \\
\hline
\end{tabular}


Liberada a substância nociva, a sua entrada e o transporte no recurso "água superficial”, pode ser via direta ou indireta, através da água subterrânea.

Assim, quando o caminho é via direta, com a entrada de sólidos e de águas contaminadas no recurso "águas superficiais", os principais fatores que influenciam são:

- instalaçóes existentes, por exemplo, canais e canalizações;

- extensão e tempo de percurso até o recurso ambiental (arraste,oxigenação, etc);

- tipo, quantidade e concentração da substância nociva (degradabilidade, sorção, persistência e volatibilidade);

- vegetação e vida no solo;

- condições microclimáticas (temperatura, condições de vento, etc).

Quando a entrada da substância nociva é feita indiretamente através da água subterrânea, os fatores que influenciam são:

- diferença de nível entre a água subterrânea e a superficial;

- declividade do nível da água subterrânea e direção de fluxo;

- alterações da substância nociva devido à percolação pelo subsolo;

- impermeabilização do fundo.

Os fatores descritos acima estão contemplados de uma forma implícita no sistema de pontuação do quadro 14.

\section{b.2.2.4. Solo}

O recurso ambiental solo possue diferentes situações em relação a área de disposição de resíduos, conforme apresentado abaixo.

(1) O solo contaminado é um recurso ambiental;

(2) O solo a proteger está abaixo do local contaminado, e é prejudicado principalmente pelo lixiviado;

(3) O solo a ser protegido é o material de cobertura do local contaminado, e pode estar principalmente prejudicado por substâncias nocivas formadoras de gás;

(4) O solo a ser protegido encontra-se na vizinhança do local contaminado.

Se o local a ser investigado for o solo contaminado, a avaliação da liberação e a entrada da substância nociva no recurso ambiental deixa de ser necessária, visto que a contaminação já está caracterizada (caso 1). Por outro lado, se o foco de risco se limita diretamente com o recurso ambiental, não existe área de migração. Portanto a avaliação deve partir das condições mais 
Quadro 14. Valores de Rn e Mn para o componente $R b_{3}$

\begin{tabular}{|c|c|c|}
\hline Qualidade da água superficial & Mn & $\mathbf{R n}$ \\
\hline Năo & 0,6 & 0 \\
\hline sim, utilizada para abastecimento público & 0,6 & 3 \\
\hline $\begin{array}{l}\text { sim, utilizada para abastecimento } \\
\text { domiciliar }\end{array}$ & 0,6 & 3 \\
\hline Sim, não utilizada & 0,6 & 1 \\
\hline $\begin{array}{l}\text { sim, utilizada para irrigação, pecuária, } \\
\text { piscicultura }\end{array}$ & 0,6 & 2 \\
\hline sim, utilizada para recreação & 0,6 & 3 \\
\hline desconhecida & 0,6 & 2 \\
\hline \multicolumn{3}{|l|}{$\begin{array}{l}\text { Possibilidade de influência direta da } \\
\text { área sobre águas superficiais }\end{array}$} \\
\hline năo & 0,4 & 0 \\
\hline sim, utilizada para abastecimento público & 0,4 & 3 \\
\hline $\begin{array}{l}\text { sim, utilizada para abastecimento } \\
\text { domiciliar }\end{array}$ & 0,4 & 3 \\
\hline sim, não utilizada & $\begin{array}{l}0,4 \\
0,4\end{array}$ & 1 \\
\hline $\begin{array}{l}\text { sim, utilizada para irrigação, pecuária, } \\
\text { piscicultura }\end{array}$ & 0,4 & 2 \\
\hline sim, utilizada para recreação & 0,4 & 3 \\
\hline desconhecida & 0,4 & 2 \\
\hline \multicolumn{3}{|l|}{$\begin{array}{l}\text { Possibilidade de enchente na área e uso } \\
\text { da água superficial }\end{array}$} \\
\hline não & 0,3 & 0 \\
\hline sim, utilizada para abastecimento público & 0,3 & 3 \\
\hline $\begin{array}{l}\text { sim, utilizada para abastecimento } \\
\text { domiciliar }\end{array}$ & 0,3 & 3 \\
\hline sim, não utilizada & 0,3 & 1 \\
\hline $\begin{array}{l}\text { sim, utilizada para irrigação, pecuária, } \\
\text { piscicultura }\end{array}$ & 0,3 & $\overline{2}$ \\
\hline sim, utilizada para recreação & 0,3 & 3 \\
\hline desconhecida & 0,3 & 2 \\
\hline
\end{tabular}


desfavoráveis (casos 2 e 3). No caso 4, o procedimento de avaliação deve considerar as condições de transporte da substância nociva do local contaminado até o recurso ambiental "solo".

Cabe ressaltar que, os solos são formados apenas em longos períodos de tempo, e quando contaminados, dificilmente são regenerados. Por outro lado, os solos têm uma alta capacidade de filtração, tamponamento e acumulação, quando colocados em contato com a maioria das substâncias nocivas e ainda, os índices de transferência de substâncias nocivas do solo para as plantas consumidas por animais são geralmente pequenos.

Para os solos superficiais, principalmente aqueles localizados nas camadas superiores, que permitem a sobrevivência de vida animal e vegetal, deve existir uma preocupação exagerada na questão da eventual fixação de substâncias nocivas por pessoas, animais e plantas.

No caso 1 , na observação da liberação de substâncias nocivas do solo contaminado devem ser considerados os seguintes fatores:

- possibilidade de entrada e saída de água, considerando especialmente o risco de erosão;

- condições de vento;

- condições de inclinação;

- condições de temperatura;

- natureza da substância nociva;

- disponibilidade de plantas;

- efeitos de troca com outras contaminações (adubação intensiva).

Em outros casos (2, 3 e 4), a distância existente entre o local de origem do resíduo/substância e o solo a ser protegido é o que determina a forma de avaliação. Neste caso, os fatores a serem considerados são os seguintes:

- quantidade e concentração de substância nociva emigrante;

- capacidade de transporte de substância nociva (peso específico, miscibilidade, solubilidade, dispersibilidade pelo vento, natureza);

- capacidade de sorção;

- reatividade com outros materiais;

- existência de meios para transporte: água, gás e ar.

De uma forma subjetiva, os fatores acima listados estão implícitos no sistema de pontuação do Quadro 15. 
Quadro 15. Valores de Rn e Mn para o componente $R b_{4}$

\begin{tabular}{|l|c|c|}
\hline \multicolumn{1}{|c|}{ Qualidade do ar do solo } & Mn & Rn \\
\hline análise não realizada & 0,3 & 2 \\
\hline contaminada & 0,3 & 3 \\
\hline não, contaminada & 0,3 & 0 \\
\hline desconhecida & 0,3 & 2 \\
\hline \multicolumn{1}{|c|}{ Eventos importantes } & & 3 \\
\hline explosão, incêndios, danos à saúde & 0,4 & 2 \\
\hline emanação perceptível de gases/vapores, \\
dispersão de poeira contaminada & 0,4 & 2 \\
\hline danos materiais, outros & & 2 \\
\hline danos à vegetação & 0,4 & 0 \\
\hline inexistente & 0,4 & \\
\hline \multicolumn{1}{|c|}{ Presença de vapores/gases nas } & 0,4 & 0 \\
\hline não & & 3 \\
\hline sim & 0,5 & 1 \\
\hline desconhecido & 0,5 & Pontos \\
\hline Distância até a edificaçăo mais próxima & & 3 \\
\hline$<50$ m & 0,4 & 2 \\
\hline 50 - 100 m & 0,4 & 1 \\
\hline$>100$ m & 0,4 & 0 \\
\hline edificações inexistentes & 0,4 & \\
\hline
\end{tabular}




\section{b.2.3. Bens a proteger}

Por final são avaliados os possíveis efeitos das substâncias nocivas sobre os bens a proteger através do risco $R c$ que soma os componentes $R c_{l}$ e $R c_{2}$. Neste caso, o primeiro componente representa a avaliação da existência dos bens a proteger na área, e o segundo, a existência de bens a proteger nas adjacências da área. Para os componentes $R c_{l}$ e $R c_{2}$, os valores de Rn e Mn são estabelecidos conforme quadro 16.

O uso da área $\left(R c_{1}\right)$, ou o uso do entorno do local de disposição $\left(R c_{2}\right)$, são fatores extremamente importantes quando é realizada a avaliação de risco de uma área de disposição de resíduos. A ocupação antrópica e/ou outros componentes ambientais que se encontram nos locais de disposição e suas adjacências, podem ser direta ou indiretamente afetados pelas substâncias tóxicas originárias dos resíduos. Entende-se, por exemplo, por relação direta, quando o ser humano é atingido por contato direto, através de ingestão de água contendo substância tóxica e/ou através de uma simples alergia de pele. $O$ efeito indireto pode ser exemplificado através de uma substância tóxica que entra na cadeia alimentar e atinge o ser humano.

Assim, através dos bens a proteger listados no quadro 16 é possível genericamente avaliar a entrada e transporte de susbstâncias nocivas no recurso ambiental. Além disso, outros bens a proteger de interesse público como matas naturais, áreas de proteção ambiental e de mananciais, parques e outros locais onde há grande circulação de pessoas encontram-se também classificados nesta categoria.

\section{b.2.4. Pontuação Final}

Assim, a pontuação final é obtida através do produto final ( $R=R a \times R b \times R c)$, conforme apresentado no quadro 17. Deve ser ressaltado que, os componentes ( $\mathrm{Ra}, \mathrm{Rb}$ e $\mathrm{Rc}$ ) somam o valor relativo a 10 e o total final de 1000 . 
Quadro 16. Valores de Rn e Mn para o componente Rc

\begin{tabular}{|l|c|c|c|}
\hline \multicolumn{1}{|c|}{$\begin{array}{c}\text { Áreas com bens a proteger / } \\
\text { Ocupação do solo }\end{array}$} & $\begin{array}{c}\mathrm{Mn} \\
\text { (dentro) }\end{array}$ & $\begin{array}{c}\mathrm{Mn} \\
\text { (fora) }\end{array}$ & $\mathrm{Rn}$ \\
\hline Zona ferroviária & 2,22 & 1,11 & 1 \\
\hline Zona viária & 2,22 & 1,11 & 1 \\
\hline Estacionamento & 2,22 & 1,11 & 1 \\
\hline Aeroporto & 2,22 & 1,11 & 1 \\
\hline Area militar & 2,22 & 1,11 & 1 \\
\hline Comercial & 2,22 & 1,11 & 1 \\
\hline Industrial & 2,22 & 1,11 & 1 \\
\hline Area de interesse público & 2,22 & 1,11 & 1 \\
\hline Mineração & 2,22 & 1,11 & 1 \\
\hline $\begin{array}{l}\text { Residencial com hortas (alta. dens. } \\
\text { pop.) }\end{array}$ & 2,22 & 1,11 & 3 \\
\hline $\begin{array}{l}\text { Residencial com hortas (baixa dens. } \\
\text { pop.) }\end{array}$ & 2,22 & 1,11 & 3 \\
\hline $\begin{array}{l}\text { Residencial sem hortas (alta dens. } \\
\text { pop.) }\end{array}$ & 2,22 & 1,11 & 3 \\
\hline $\begin{array}{l}\text { Residencial sem hortas (baixa dens. } \\
\text { pop.) }\end{array}$ & 2,22 & 1,11 & 3 \\
\hline Parque, área verde & 2,22 & 1,11 & 2 \\
\hline Parque infantil/escola infantil & 2,22 & 1,11 & 3 \\
\hline Area de lazer e desportos & 2,22 & 1,11 & 2 \\
\hline Cemitérios & 2,22 & 1,11 & 1 \\
\hline Escola & 2,22 & 1,11 & 2 \\
\hline Hortas & 2,22 & 1,11 & 3 \\
\hline Área de pecuária & 2,22 & 1,11 & 1 \\
\hline Area agrícola & 2,22 & 1,11 & 3 \\
\hline Mata natural & 2,22 & 1,11 & 1 \\
\hline Área de protecão ambiental & 2,22 & 1,11 & 2 \\
\hline Area de protecão de mananciais & 2,22 & 1,11 & 2 \\
\hline $\begin{array}{l}\text { Bacia hidrográfica para } \\
\text { abastecimento }\end{array}$ & 2,22 & 1,11 & 3 \\
\hline Aquiferos importanes & 2,22 & 1,11 & 2 \\
\hline $\begin{array}{l}\text { Zona de maior restrição de proteção } \\
\text { de mananciais }\end{array}$ & 2,22 & 1,11 & 3 \\
\hline Area inundável, várzea & 2,22 & 1,11 & 2 \\
\hline Represa para abastecimento público & 2,22 & 1,11 & 3 \\
\hline $\begin{array}{l}\text { Agua superficial para abastecimento } \\
\text { público }\end{array}$ & 2,22 & 1,11 & 3 \\
\hline Poço para abastecimento público & 2,22 & 1,11 & 3 \\
\hline Poço para abastecimento domiciliar & 2,22 & 1,11 & 3 \\
\hline
\end{tabular}


Quadro 17 - Totalização do sistema de pontuação

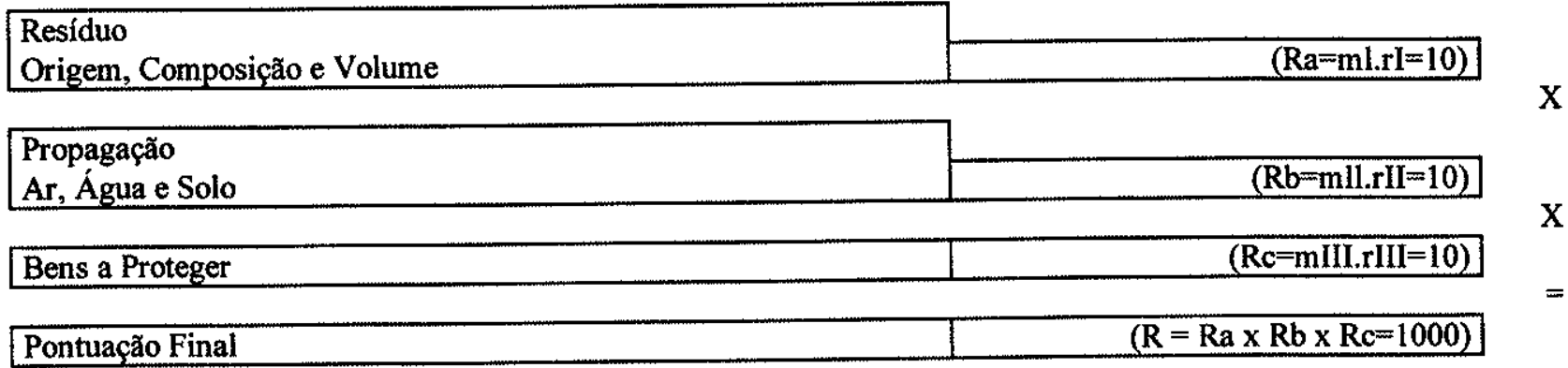

\subsection{Avaliação Confirmatória}

A avaliação confirmatória em áreas de disposição de resíduos sólidos deve considerar os quatro meios de propagação incluídos na avaliação preliminar: solo, ar, água superficial e subterrânea. Nesta etapa denominada avaliação confirmatória, a investigação deve restringir-se a estes meios.

Nos locais de disposição, os gases e lixiviados gerados são os principais causadores de contaminação nos quatro meios discriminados acima.

A composição dos gases provenientes da decomposição de resíduos sólidos pode ser definida pelos constituintes maiores $\mathrm{CH}_{4}, \mathrm{CO}_{2}, \mathrm{H}_{2} \mathrm{~S}, \mathrm{~N}_{2}, \mathrm{O}_{2}$ e $\mathrm{H}_{2}$ (USEPA, 1994) e elementos traços como benzeno, tolueno, xileno, pentano, etilbenzeno, propilbenzeno, hexano, tolueno, diclorometano, 1,1-dicloroetileno, 1,2-dicloroetileno, tricloroetileno, 1,1,2-tricloroetano, tetracloroetileno, tetrahidrofurano e hexano.

A Figura 3, mostra a evolução da concentração dos gases $\mathrm{CH}_{4}, \mathrm{CO}_{2}, \mathrm{~N}_{2}, \mathrm{O}_{2}$ e $\mathrm{H}_{2}$, em função do tempo, após o encerramento da disposição de resíduos. Inicialmente, os gases existentes no local de deposição apresentam-se praticamente com a mesma composição e distribuição dos gases atmosféricos, cerca de $80 \%$ de nitrogênio e $20 \%$ oxigênio e pequenas concentrações de $\mathrm{CO}_{2}$ e outro gases. Em seguida, os microorganismos presentes no local de deposição iniciam a degradação da matéria orgânica. A concentração de $\mathrm{O}_{2}$ diminui e a do $\mathrm{CO}_{2}$ aumenta, e as condições aeróbias passam gradativamente a mudar para anaeróbias. Inicialmente, a concentração de $\mathrm{CH}_{4}$ é muito baixa, mas aumenta ao longo do tempo, e $\mathrm{CO}_{2}$ passa a diminuir paralelamente. 


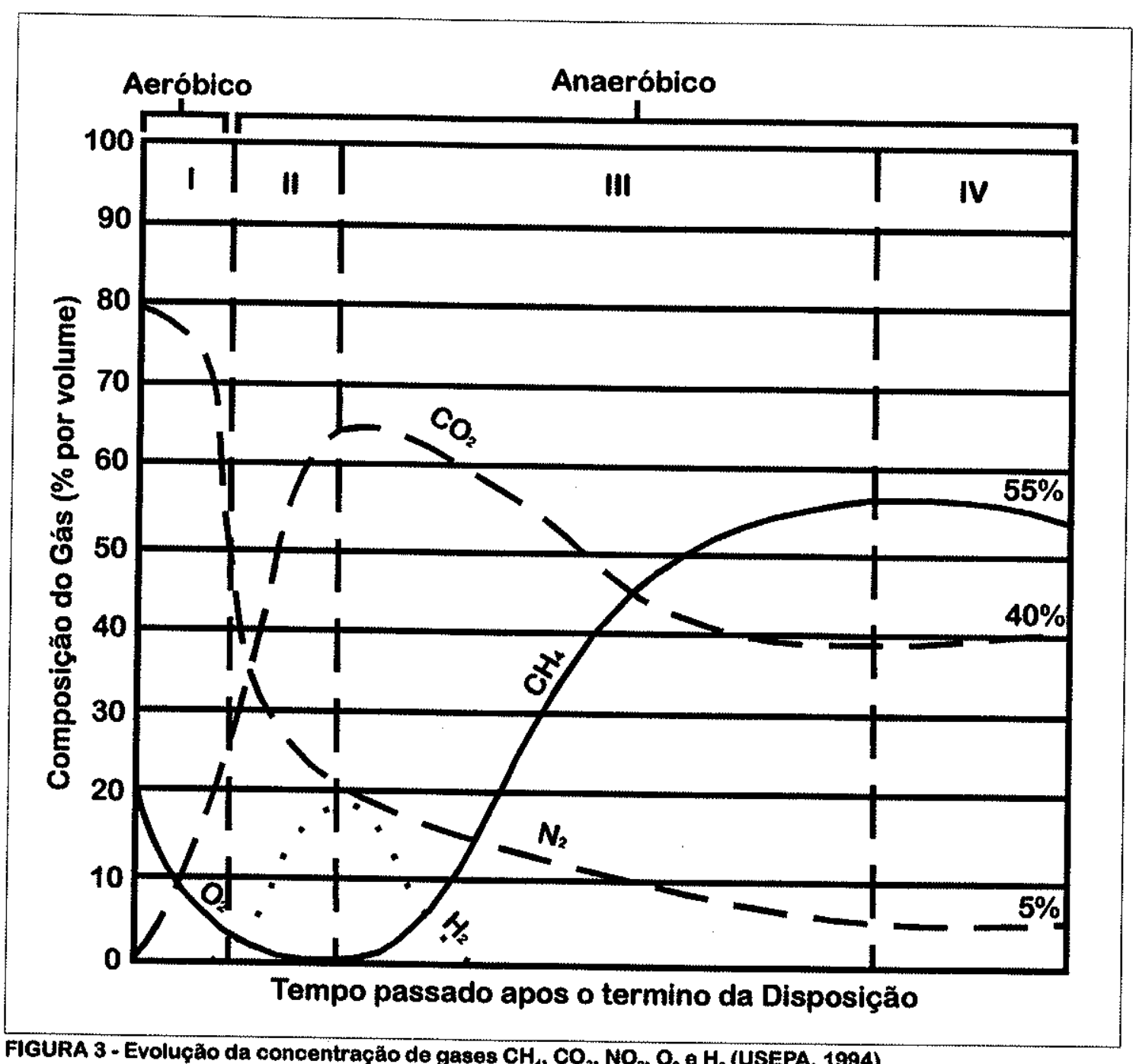

FIGURA 3 - Evoluçăo da concentração de gases $\mathrm{CH}_{4}, \mathrm{CO}_{2}, \mathrm{NO}_{2}, \mathrm{O}_{2}$ e $\mathrm{H}_{2}$ (USEPA, 1994) 
A composição química do lixiviado pode ser caracterizada genericamente conforme apresentada na tabela 5 .

Assim como no caso dos gases, a concentração dos lixiviados varia em função do tempo, conforme apresentado na tabela 6. Da mesma forma que no caso dos gases, no aterro recente observam-se altos valores de concentração de DBO indicando alta atividade bioquímica e no aterro antigo os valores observados são baixos. Da mesma forma, o valor de TOC é alto no aterro recente e baixo no aterro antigo, indicando a degradação da matéria orgânica em função do tempo, enquanto que os ácidos orgânicos são observados no aterro recente, mas no aterro antigo não são detectados na análise química.

$\mathrm{Na}$ tabela 7 encontram-se listadas as substâncias inorgânicas e orgânicas que podem ser detectadas nos locais de disposição de resíduos sólidos conforme USEPA (1994). Cabe notar que entre as substâncias orgânicas listadas predominam compostos que são considerados traços.

Dentro deste quadro, observa-se que os critérios que permitem a classifiçação de uma área como "contaminada", ainda não estão definidos para o Estado de São Paulo, ou mesmo para qualquer outro estado do país. A inexistência desses critérios fez com que fossem avaliadas as metodologias empregadas por outros países no processo de classificação de áreas contaminadas de modo a auxiliarem no processo da avaliação confirmatória. Desta forma, em função de sua ampla utilização na Europa, decidiu-se pela adoção dos valores referenciais empregados pela Holanda (VROM, 1994), onde são estabelecidos três niveis de referência, tanto para o solo como para a água subterrânea:

nível S - indica o nível de qualidade ambiental, sem quaisquer restrições de uso para o meio investigado.

- nível T - valor intermediário, utilizado como um indicador de um certo declínio nas propriedades do meio investigado. Investigações adicionais são requeridas se este valor for ultrapassado.

- nível I - valor de intervenção. Indica os níveis de qualidade acima dos quais existe um risco para o homem e o ecossistema.

No tabela 8 podem ser observados os valores referenciais para os três níveis. Nele constam os valores para alguns metais, compostos inorgânicos, compostos aromáticos, hidrocarbonetos policíclicos aromáticos, hidrocarbonetos clorados e pesticidas. Com certeza, os parâmetros relacionados não abrangem todo o universo de substâncias químicas que podem ser 
Tabela 5. Composição química de lixiviado de aterros da RMSP (CETESB, 1993)

\begin{tabular}{|c|c|c|c|c|c|c|}
\hline & 1 & 2 & 3 & 4 & 5 & 6 \\
\hline $\mathrm{pH}$ & 7,49 & 7,94 & 7,10 & 6,60 & 5,40 & 8,50 \\
\hline Cond. Elétr. & 21.300 & 16.900 & 4.437 & & & \\
\hline \begin{tabular}{|l} 
Res. Total \\
\end{tabular} & 5.599 & 7.258 & 6.267 & 14.431 & 3.155 & 18.709 \\
\hline Res. Fixo & & & & 7.825 & 1.646 & 12.967 \\
\hline Res. Volátil & 2.310 & 4.110 & 1.923 & 6.740 & 1.715 & 5.769 \\
\hline Res. Filtrável & & & & 10.764 & 3.106 & 18.701 \\
\hline Res. N. Filtrável & 317 & 171 & 3.240 & 3.678 & 249 & 178 \\
\hline Res. N. Filtr. Vol. & 209 & 122 & - & & & \\
\hline Res. Sediment. & 0,81 & 0,25 & 69,33 & 20,50 & $<1,3$ & $<0,5$ \\
\hline Alc. bicarb. & 3.400 & 2.665 & 1.014 & & & \\
\hline Nitr. Amoniacal & & & & 549 & 75 & 2.564 \\
\hline Nitr. Nitrito & & & & 0,003 & 0,02 & - \\
\hline Nitr. Nitrato & & & & 0,65 & 0,13 & 2,24 \\
\hline Nitr. Kjedhal & 1.419 & 395 & 160 & 709 & 127 & 2.729 \\
\hline DBO (5 dias, $\left.20^{\circ}\right)$ & 3.869 & 5.070 & 2.643 & 10.919 & 3.738 & 1.389 \\
\hline DQO & 4.133 & 6.355 & 3.063 & 18.110 & 5.836 & 6.671 \\
\hline Cloreto & & & & 2.341 & 311 & 138 \\
\hline Sulfato & 114 & $<2$ & 6 & $<70$ & 33 & 1.223 \\
\hline \begin{tabular}{|l|} 
Fósforo Total \\
\end{tabular} & & & & 7,40 & 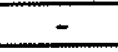 & - \\
\hline Fosfato Total & 6,89 & 10,35 & 6,71 & & & \\
\hline Ferro & 52,9 & 23,18 & 1041 & 1.121 & 84,4 & 20,1 \\
\hline Cobre & 0,38 & 0,015 & 0,07 & 0,29 & 0,05 & 0,28 \\
\hline Chumbo & 0,20 & 0,175 & 254 & 0,69 & 0,09 & 0,44 \\
\hline Niquel & 0,19 & 0,11 & 0,12 & & & \\
\hline Zinco & 1,47 & 0,31 & 0,47 & 10,36 & 2,33 & 1,03 \\
\hline Manganês & 3,57 & 3,96 & 12,27 & 15,17 & 4,19 & 0,21 \\
\hline Magnésio & 101,89 & 57,7 & 81,33 & & & \\
\hline Cádmio & 0,02 & 0,01 & 0,01 & 0,08 & 0,01 & - \\
\hline Alumino & $<1,29$ & 1,94 & 212,13 & & & \\
\hline Bário & $<0,14$ & 0,23 & 5,01 & & & \\
\hline Cálcio & 114,77 & 43,2 & $=$ & & & \\
\hline Potássio & 553 & 665 & 308 & & & \\
\hline Sódio & 303 & 648 & 288 & & & \\
\hline Cromo Hexav. & & & & $<0,014$ & - & $=$ \\
\hline Cromo Total & 0,08 & 0,095 & 1,00 & 0,75 & 0,35 & 0,97 \\
\hline Óleos e graxas & 34 & 27 & 126 & & & \\
\hline Colif. Totais & & & & 1,7E6 & - & $2,3 E 5$ \\
\hline Colif. Fecais & & & & 1,7E5 & $z$ & 3,3E4 \\
\hline
\end{tabular}
1. Aterro Sanitário de Santo André
2. Aterro Sanitário dos Bandeirantes
3. Aterro Sanitário de Itapecerica de Serra
4. Aterro Sanitário de Vila Albertina
5. Aterro Sanitário Eng. Goulart
6. Aterro Sanitário Raposo Tavares $\mathrm{Km}$ 14,5 
Tabela 6. Variação da concentração dos constituintes do lixiviado em função do tempo (CETESB, 1992b)

\begin{tabular}{|c|c|c|}
\hline Parâmetro & Aterro Recente (1 ano) & $\begin{array}{c}\text { Aterro Antigo (+ de } 20 \\
\text { anos) }\end{array}$ \\
\hline $\mathrm{pH}$ & 6,9 & 7,1 \\
\hline DBO & 4286 & 55 \\
\hline DQO & 6050 & 96 \\
\hline TOC & 2040 & 38 \\
\hline Nitr. Orgânico & 16 & 8 \\
\hline Nitr. Nitrato & 0,77 & 85 \\
\hline Nitr. Nitrito & 0,63 & 0,84 \\
\hline Nitr. Amoniacal & 224 & 34 \\
\hline Ortofosfato & 0,16 & 0,30 \\
\hline Cloretos & 2777 & 520 \\
\hline Sulfatos & 218 & - \\
\hline Sódio & 1590 & 380 \\
\hline Magnésio & 215 & 35 \\
\hline Potássio & 320 & 135 \\
\hline Cálcio & 700 & 230 \\
\hline Cromo & 0,09 & 0,02 \\
\hline Manganês & 13,5 & 0,19 \\
\hline Ferro & 38 & 0,10 \\
\hline Niquel & 0,03 & 0,03 \\
\hline Cobre & 0,03 & 0,15 \\
\hline Zinco & 0,20 & 0,95 \\
\hline Cádmio & 0,01 & 0,005 \\
\hline Chumbo & 0,08 & 0,06 \\
\hline Carbohidratos & 62 & 16 \\
\hline Ac. acético & 750 & 4 \\
\hline Ac. propiônico & 339 & ND \\
\hline Ac. iso-butírico & 83 & ND \\
\hline Ac. n-butírico & 334 & ND \\
\hline Ac. iso-valérico & 76 & ND \\
\hline Ac. $n$-valérico & 142 & ND \\
\hline Ac. iso-capróico & 61 & ND \\
\hline Ac. $n$-capróico & 127 & ND \\
\hline
\end{tabular}


Tabela 7. Substâncias possíveis de serem encontradas nos lixiviados nos locais de disposição de resíduos sólidos (EPA, 1994).

\begin{tabular}{l}
\hline Subst. Inorgánicas \\
\hline 1. Antimónio \\
2. Arsénio \\
3. Bário \\
4. Berílio \\
5. Cádmio \\
6. Cromo \\
7. Cobalto \\
8. Cobre \\
9. Chumbo \\
10. Niquel \\
11. Selénio \\
12. Prata \\
13. Tálio \\
14. Vanádio \\
15. Zinco \\
\hline Subst. Orgánicas \\
\hline 16. Acetona \\
17. Acrilonitrilo \\
18. Benzeno \\
19. Bromoclorometano \\
20. Bromodiclorometano \\
21. Bromofórmio, \\
Tribromometano \\
22. Dissulfeto de Carbono \\
23. Tetracloreto de Carbono \\
24. Clorobenzeno \\
25. Cloroetano; Cloreto de Etila \\
26. Clorofórmio, Triclorometano \\
27. Dibromoclorometano, \\
Clorodibromometano \\
28. 1,2-Dibromo-3-cloropropano; DBCP \\
29. 1,2-Dibromoetano; Dibrometo de Etila \\
30. O-Diclorobenzeno; 1,2-Diclorobenzeno \\
31. P-Diclorobenzeno; \\
1,4-Diclorobenzeno \\
32. Trans-1,4-Dicloro-2-butano \\
\end{tabular}

\begin{tabular}{l}
\hline Subst. Orgánicas \\
\hline 33. 1,1-Dicloroetano \\
34. 1,2-Dicloroetano, Dicloroetileno \\
35. 1,1-Dicloroetileno; 1,1-Dicloroeteno \\
36. Cis-1,2-Dicloroetileno; cis-1,2-Dicloroeteno \\
37. Trans-1,2-Dicloroetileno; trans-1,2- \\
Dicloroeteno \\
38. 1,2-Dicloropropano \\
39. cis-1,2-Dicloropropeno \\
40. trans-1,3-Dicloroproneno \\
41. Etilbenzeno \\
42. 2-Hexanone; Metil butil ketone \\
43. Brometo de metila; Bromometano \\
44. Cloreto de metila, clorometano \\
45. Brometo de metileno, \\
Dibromometano \\
46. Cloreto de Metileno, clorometano \\
47. Metil-etil-ketone;MEK; 2-Butanona \\
48. Iodeto de meltila; iodometano \\
49. 4-Metil-2-Pentanona; Metil isobutil ketone \\
50. Estireno \\
51. 1,1,12-Tetracloroetano \\
52. 1,1,2,2-Tetracloroetano \\
53. Tetracloroetileno; tetracloroeteno, \\
Percloroetileno \\
54. Tolueno \\
55. 1,1,1-Tricloroetano; Metilciorofórmio \\
56. 1,1,2-Tricloroetano \\
57. Tricloroetileno; Tricloroeteno \\
58. Triclorofluorometano; CFC-11 \\
59. 1,2,3-Tricloropropano \\
60. Acetato de Vinila \\
61. Cloreto de Vinila \\
62. Xileno \\
\hline
\end{tabular}


Tabela 8 - Valores referenciais da Holanda para solo e água subterrânea (VROM, 1994)

\begin{tabular}{|c|c|c|c|c|c|c|}
\hline SUBSTANCIAS & $\mathbf{S}$ & $\mathbf{T}$ & $\mathbf{I}$ & $\mathbf{S}$ & $\mathbf{T}$ & I \\
\hline \multicolumn{7}{|c|}{ HIDROCARBONETOS POLICICLICOS AROMÁTICOS } \\
\hline Benzo(a)pireno & - & - & - & 0,001 & 0,026 & 0,05 \\
\hline Benzo(ghl)perileno & - & - & - & 0,0002 & 0,025 & 0,05 \\
\hline Indeno(1,2,3cd)pireno & - & - & - & 0,0004 & 0,025 & 0,05 \\
\hline PAH (Soma) & 1,00 & 20,5 & 40,0 & - & - & - \\
\hline \multicolumn{7}{|l|}{ HIDROCARBONETOS CLORADOS } \\
\hline Diclorometano & F- & 10,0 & 20,0 & 0,01 & 500 & 1000 \\
\hline Triclorometano & 0,0010 & 5,0 & 10,0 & 0,01 & 200 & 400 \\
\hline Tetraclorometano & 0,0010 & 0,5 & 1,0 & 0,01 & 5 & 10 \\
\hline 1,1-dicloroetano & - & 25 & 50 & - & 1300 & 2600 \\
\hline 1,2-dicloroetano & - & 2,0 & 4,0 & 0,01 & 200 & 400 \\
\hline 1,1,1-tricloroetano & - & 25 & 50 & - & 275 & 550 \\
\hline 1,1,2-tricloroetano & - & 25 & 50 & - & 750 & 1500 \\
\hline Cloreto de Vinila & - & 0,050 & 0,100 & - & 0,35 & 0,7 \\
\hline 1,2-cis-dicloroeteno & - & 25 & 50 & - & 650 & 1300 \\
\hline Tricloroeteno & 0,0010 & 30,0 & 60,0 & 0,01 & 250 & 500 \\
\hline \begin{tabular}{|l} 
Tetracloroeteno \\
\end{tabular} & 0,010 & 2,0 & 4,0 & 0,01 & 20 & 40 \\
\hline Restante dos Hidrocarbonetos Clorados & - & 25 & 50 & - & - & - \\
\hline Clorobenzenos (Soma) & - & 15,0 & 30 & - & - & - \\
\hline Monoclorobenzeno & - & - & - & 0,01 & 90 & 180 \\
\hline Diclorobenzeno (Soma) & 0,010 & - & - & 0,01 & 25 & 50 \\
\hline Triclorobenzeno (Soma) & 0,010 & - & - & 0,01 & 5 & 10 \\
\hline Tetraclorobenzeno (Soma) & 0,010 & - & - & 0,01 & 1,26 & 2,5 \\
\hline Pentaclorobenzeno & 0,0025 & - & - & 0,01 & 0,5 & 1 \\
\hline Hexaclorobenzeno & 0,0025 & - & - & 0,01 & 0,26 & 0,5 \\
\hline Clorofenóis (Soma) & - & 5,0 & 10 & - & - & - \\
\hline Monoclorofenóis (Soma) & 0,0025 & - & - & 0,25 & 50 & 100 \\
\hline Diclorofenóis (Soma) & 0,0030 & - & - & 0,08 & 15 & 30 \\
\hline Triclorofenóis (Soma) & 0,0010 & - & - & 0,025 & 5 & 10 \\
\hline Tetraclorofenóis (Soma) & 0,0010 & - & - & 0,01 & 5 & 10 \\
\hline Pentaclorofenóis & 0,0020 & 2,5 & 5,0 & 0,02 & 1,5 & 3 \\
\hline Cloronaftaleno & - & 5,0 & 10,0 & - & 3 & 6 \\
\hline PCB (Soma) & 0,020 & 0,5 & 1,0 & $\overline{0,01}$ & 0,01 & 0,01 \\
\hline
\end{tabular}


Tabela 8 - Valores referenciais da Holanda para solo e água subterrânea (VROM, 1994) (Continuação)

\begin{tabular}{|c|c|c|c|c|c|c|}
\hline SUBSTÂNCIAS & $\mathbf{S}$ & $\mathbf{T}$ & $\mathbf{I}$ & $\mathbf{S}$ & $\mathbf{T}$ & $\mathbf{I}$ \\
\hline \multicolumn{7}{|l|}{ PESTICIDAS } \\
\hline DDD, DDE, DDT (Soma) & 0,0025 & 2,00 & 4,0 & - & 0,005 & 0,01 \\
\hline Aldrin & 0,0025 & - & - & - & - & - \\
\hline Dieldrin & 0,0005 & $\overline{-}$ & - & 0,00002 & - & - \\
\hline Endrin & 0,0010 & - & - & - & - & - \\
\hline Compostos de BHC (Soma) & - & 1,00 & 2,0 & - & 0,5 & 1 \\
\hline Alfa-BHC & 0,0025 & - & - & - & - & 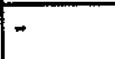 \\
\hline Beta-BHC & 0,0010 & - & - & - & - & - \\
\hline Gama-BHC & 0,00005 & - & - & - & - & - \\
\hline Carbaril & - & 2,50 & 5 & 0,01 & 0,06 & 0,1 \\
\hline Carbofurano & - & 1,00 & 2,0 & 0,01 & 0,06 & 0,1 \\
\hline Atrazina & 0,00005 & 3,00 & 6,0 & 0,0075 & 75 & 150 \\
\hline \multicolumn{7}{|l|}{ OUTROS COMPOSTOS } \\
\hline Ciclohexanona & 0,10 & 135,1 & 270 & 0,5 & 7500 & 15000 \\
\hline Ftalatos (Soma) & 0,10 & 30,1 & 60 & 0,5 & 2,75 & 5 \\
\hline Hidrocarbonetos de Petróleo Total (TPH) & 50 & 2525 & 5000 & 50 & 325 & 600 \\
\hline Piridina & 0,10 & 0,55 & 1,0 & 0,5 & 1,75 & 3 \\
\hline Estireno & 0,10 & 50,1 & 100 & 0,5 & 150 & 300 \\
\hline Tetrahidrofurano & 0,10 & 0,25 & 0,40 & 0,5 & 0,75 & 1 \\
\hline Tetrahidrotiofeno & 0,10 & 45,1 & 90 & 0,5 & 15 & 30 \\
\hline
\end{tabular}


encontradas nos locais de disposição de resíduos sólidos. Mas, por outro lado, é a relação mais completa e aceita pela comunidade científica.

\subsection{Caracterização da Área}

A caracterização da área é uma etapa na qual procura-se definir a extensão dos efeitos dos gases e lixiviados sobre os 4 meios (solo, ar, água superficial e subterrânea) existentes no local ou nas adjacências do local de deposição. Além disso, nesta etapa ainda podem ser geradas informações necessárias e pertinentes para a remediação.

Inicialmente, a caracterização inclui a compilação de todas as informações históricas da área, tais como: arquivo fotográfico, entrevista aos operadores, análise do projeto do local, consulta aos arquivos da empresa operadora e levantamento de dados geológicos, hidrogeológicos e hidrológicos.

Em seguida, realiza-se uma investigação detalhada no local, que inclui poços de monitoramento, amostragens de ar, água e solo, execução de métodos geofísicos, análise integrada dos dados, e avaliação da tecnologia de remediação factível.

Informações mais detalhadas sobre a caracterização de áreas encontram-se descrita em CONSONI (1981), USEPA (1989), USEPA (1991) e GUIGUER (1987). Deve ser observado que o detalhamento desta etapa foge ao objetivo desta tese.

\subsection{Recuperação da Área}

A recuperação de uma área contaminada pressupõe a seleção e implementação de tecnologia adequada. A tecnologia selecionada para atingir o objetivo da remediação deve:

- proteger a saúde humana e o meio ambiente;

- atingir padrões de qualidade de ar, água (superficial e subterrânea) e solo;

- controlar ao máximo, reduzir ou eliminar, a fonte de liberação de contaminantes;

- obedecer as normas, guias e diretrizes do órgão ambiental.

Na seleção da tecnologia de remediação devem ser considerados os seguintes fatores:

- A eficiência a curto e longo prazo, da técnica de remediação;

- A efetividade da técnica de remediação no controle de redução de futuras liberações de contaminantes;

- A facilidade ou dificuldade da implementação da técnica de remediação; 
- Capacitação técnica e financeira;

- A aceitabilidade pela comunidade em relação à técnica selecionada. 


\section{PARTE 2. ESTUdOS DE CASOS NA REGIÃo METROPOLITANA DE SÃo PAULO}

7. AVALIAÇÃo REGIONAL: Região Metropolitana de São Paulo (RMSP)

Os últimos dois capítulos da tese apresentam a aplicação do modelo de gestão de áreas contaminadas elaborada para a Região Metropolitana de São Paulo. Apesar do modelo ser aplicável para vários tipos de fontes de contaminação (indústria, comércio, postos de serviços, acidentes, etc.), os dados apresentados nos capítulos subsequentes referem-se especificamente às áreas de disposição de resíduos sólidos.

Como descrito na Parte 1, o Sistema de Classificação elaborado permite realizar a avaliação do risco de contaminação em três etapas. Inicialmente a avaliação é feita a partir da fonte de contaminação, seguida dos vários caminhos que a substância nociva e/ou seus derivados podem tomar para se propagar através dos meios ar, solo, água superficial e água subterrânea. Por final efetua-se a análise da existência de bens a proteger, na área de disposição e/ou nas suas adjacências, que podem ser prejudicados ou danificados pelos efeitos das substâncias originárias do local de disposição. Dessa forma, neste capítulo de Avaliação Regional, é feita preliminarmente diagnóstico dos aspectos sócio-econômicos, recursos hídricos superficiais e subterrâneos e área de disposição de resíduos.

A discussão sobre aspectos sócio-econômicos da RMSP é feita com enfoque em uso e ocupação do solo, para posteriormente poder confrontar com os resultados da Avaliação Preliminar, tanto no aspecto saúde e vida da população (BP1) como no do uso do solo (BP3).

Em seguida, descreve-se um diagnóstico sobre águas superficiais e água subterrânea da RMSP. Este diagnóstico foi realizado para fins de comparação com os resultados da pontuação dos bens a proteger (abastecimento püblico (BP2) e proteção das águas subterrâneas e superficiais (BP4)).

Por final, apresenta-se, um diagnóstico das áreas de disposição de resíduos da RMSP, seguido de classificação e priorização das mesmas áreas. 


\subsection{Aspectos sócio-econômicos}

A região metropolitana de São Paulo segundo SEADE (1995), possui uma área de 8.051 $\mathrm{km}^{2}$ e população de 15.902 .412 pessoas, com uma densidade demográfica de 1914,84 habitantes $/ \mathrm{km}^{2}$ e arrecadação de ICMS de R\$ 7.828.388.683. Confrontando estes valores com os correspondentes ao do Estado de São Paulo observa-se que a região, apesar de ocupar apenas $3,24 \%$ da área total $\left(248.600 \mathrm{~km}^{2}\right)$, concentra quase a metade da população estadual com uma densidade demográfica 15 vêzes maior ao valor médio do Estado e arrecada $62 \%$ do ICMS total.

$\mathrm{Na}$ figura 4 pode ser observado quadro e mapa demonstrando a distribuição da população por município da RMSP. Dos 39 municípios que compõem a RMSP, o município de São Paulo destaca-se por apresentar 61,6\% (9.800.997 pessoas) da população total. Em seguida destacam-se os municípios de Guarulhos com 5,2\% (830.056 pessoas), Santo André com 3,9\% (619.904 pessoas) e São Bernardo do Campo com 3,7\% (587.854 pessoas) (FIGURA 4). Nessa figura observa-se que somente 4 municípios da região concentram $74,4 \%$ da população numa área que corresponde a $30 \%\left(2435 \mathrm{~km}^{2}\right)$ do total. Outros 15 municípios localizados ao longo da Rodovia Castelo Branco (Osasco, Carapicuíba, Barueri e Itapevi), Rodovia Raposo Tavares (Cotia), Rodovia Regis Bittencourt (Taboão da Serra e Embu), Rodovia Airton Senna (Guarulhos, Itaquaquecetuba, Ferraz de Vasconcelos, Suzano e Mogi das Cruzes) e ainda Mauá, Diadema e São Caetano do Sul, possuem uma população variando entre 100.000 e 400.000 pessoas. Os 20 municípios restantes apresentam uma população menor que 100.000 pessoas e localizam-se nas regiões mais distantes das zona leste, norte e sul da RMSP (FIGURAS 4).

Por outro lado, se a análise populacional da RMSP for realizada em termos de densidade demográfica o quadro torna-se um pouco diferente do apresentado anteriormente. Os 6 municípios da região que possuem mais alta densidade demográfica incluem São Caetano do Sul $\left(12.433,58\right.$ habitantes $\left./ \mathrm{km}^{2}\right)$, Diadema $\left(9.533,38\right.$ habitantes $\left./ \mathrm{km}^{2}\right)$, Carapicuíba $(7.879,25$ habitantes $\left./ \mathrm{km}^{2}\right)$, Osasco $\left(8.337,49\right.$ habitantes $\left./ \mathrm{km}^{2}\right)$, Taboão da Serra $\left(7994,7\right.$ habitantes $\left./ \mathrm{km}^{2}\right)$ e São Paulo $\left(6.379,65\right.$ habitantes $/ \mathrm{km}^{2}$ ) (FIGURA 5). Outros 19 municípios que se localizam nos arredores de São Paulo possuem densidade demográfica maior que 500 habitantes $/ \mathrm{km}^{2}$, conforme observa-se no quadro da figura 5 . O restante dos municípios que são mais periféricos e somam um total de 15 , possuem densidade demográfica entre 27 e 391 habitantes $/ \mathrm{km}^{2}$. 


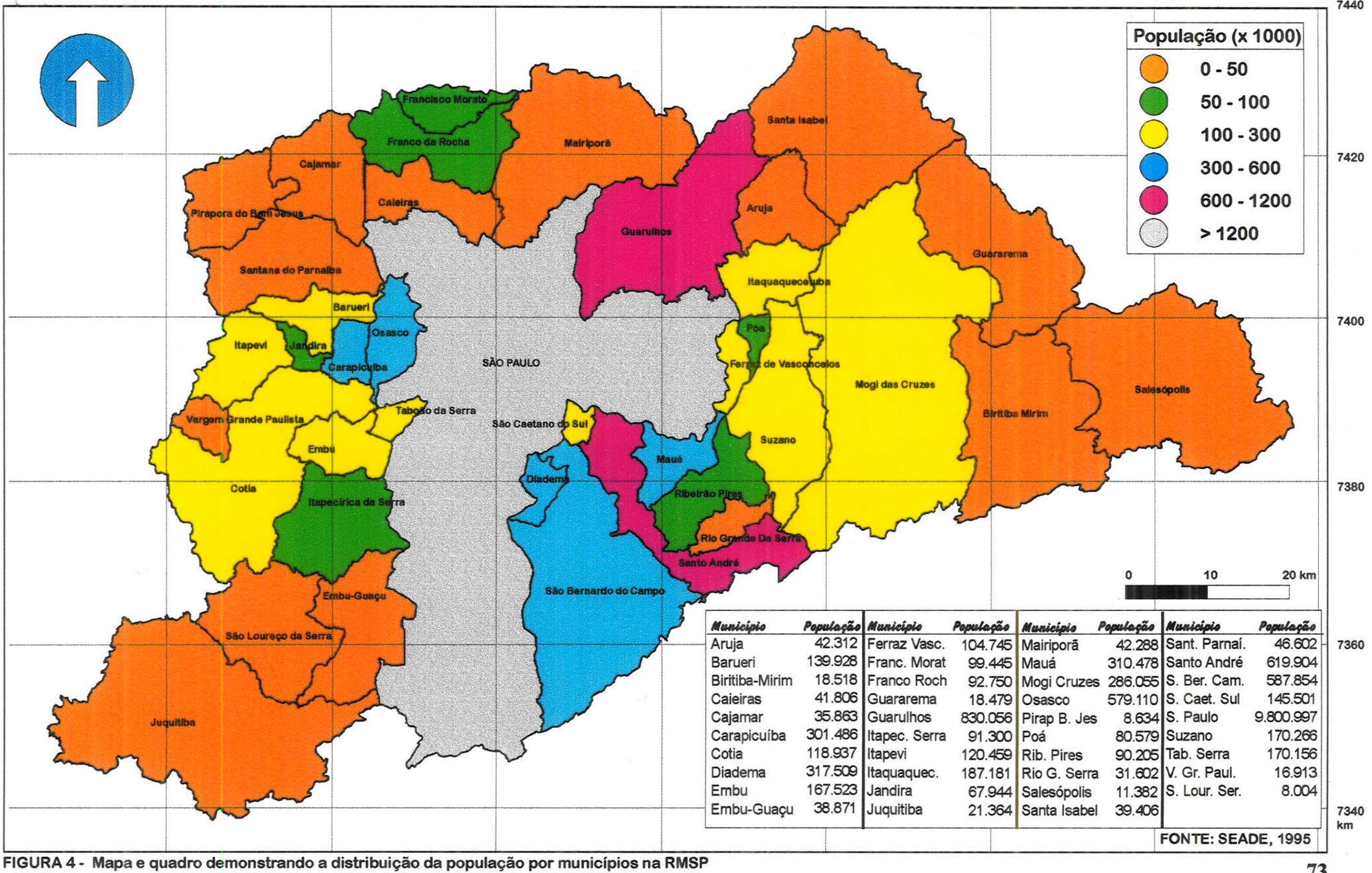




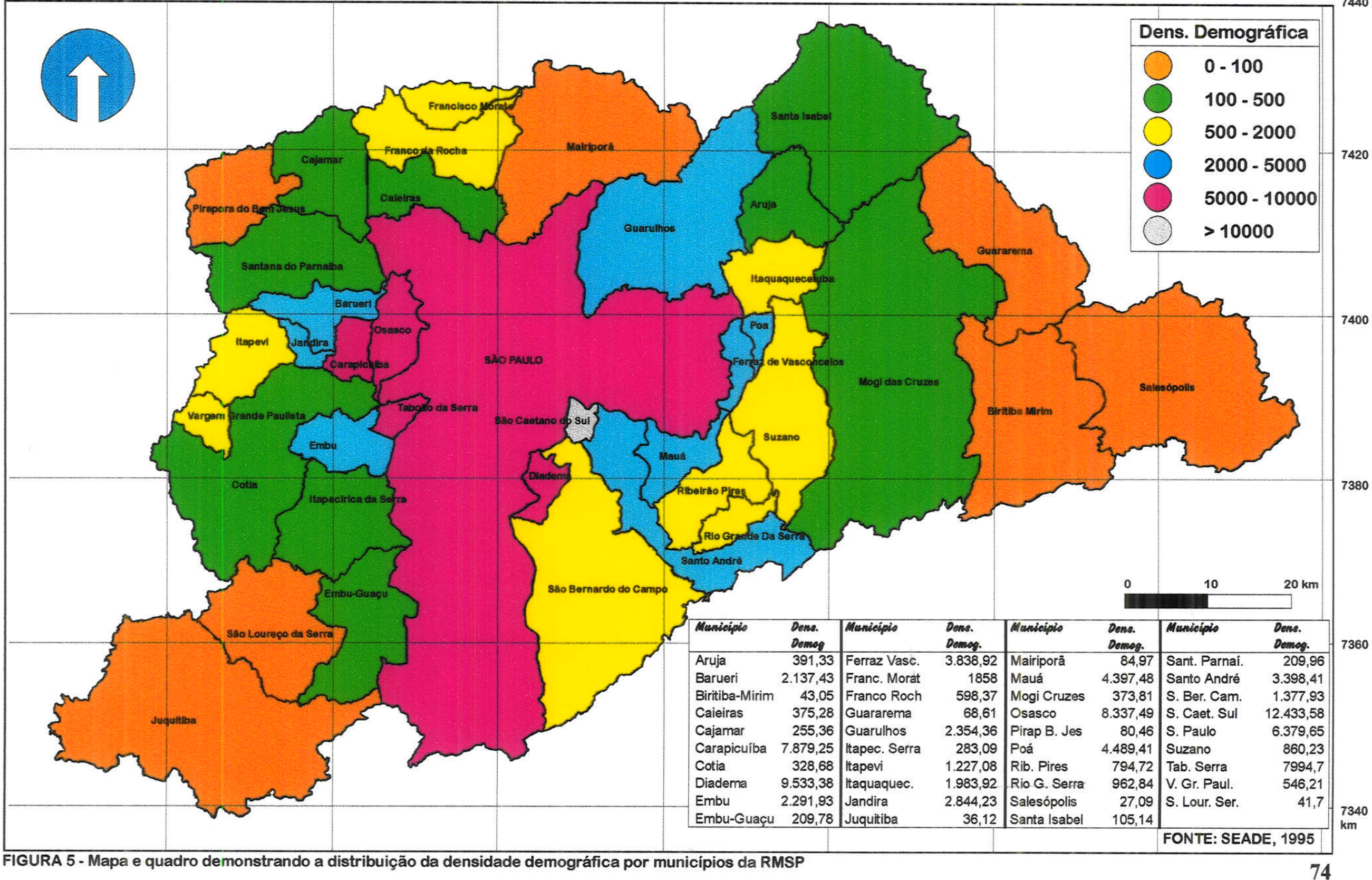


$\mathrm{Na}$ região, os valores da taxa de urbanização atingem a cifra altíssima de $97,84 \%$, enquanto a taxa populacional geométrica de crescimento anual é de 1,86\%. Portanto, a RMSP apresenta alta taxa de urbanização e também alto valor de densidade demográfica, como consequência, praticamente não dispõe de área a ser ocupada. Este reflexo pode ser observado pelo baixo índice de taxa populacional geométrica de crescimento anual, valor este considerado como crescimento vegetativo por especialistas no assunto.

Na década de 80 , a população total da RMSP era de 12.549 .856 habitantes. Destes, 12.147.273 habitantes $(96,8 \%)$ ocupavam a área urbana e 402.583 habitantes $(3,2 \%)$ a área rural. Passada uma década, em 1990, este quadro passou para uma população total de 15.089 .744 habitantes, das quais $14.749 .147(97,7 \%)$ residem na área urbana e 340.597 habitantes $(2,3 \%)$ na área rural. Dessa forma, observa-se que a população da RMSP é essencialmente urbana e esta população tem aumentado percentualmente em relação a rural ao longo do tempo.

\subsection{Diagnóstico dos Recursos Hídricos na RMSP}

A RMSP conta atualmente com aproximadamente 16 milhões de habitantes, que são abastecidos basicamente por água de superficie, tanto proveniente do Sistema Integrado de Produção e Adução quanto dos Sistemas Isolados (FIGURA 6). A demanda média de água, para o Sistema Integrado da RMSP, está estimada em aproximadamente $48,9 \mathrm{~m}^{3} / \mathrm{s}$ e nos sistemas isolados em cerca de $8,8 \mathrm{~m}^{3} / \mathrm{s}$ (SABESP, 1995). O abastecimento de água na RMSP é complementado por água subterrânea nas áreas não servidas pelo Sistema Integrado, em locais isolados e onde há necessidade de suplementação de água da SABESP por água subterrânea. A utilização da água subterrânea na RMSP é feita através de cerca de 7.000 poços profundos ativos de um total de 10.000 perfurados.

\subsection{1. Águas Superficiais}

O diagnóstico das águas superficiais é apresentado a seguir considerando aspectos quantitativos e qualitativos. 


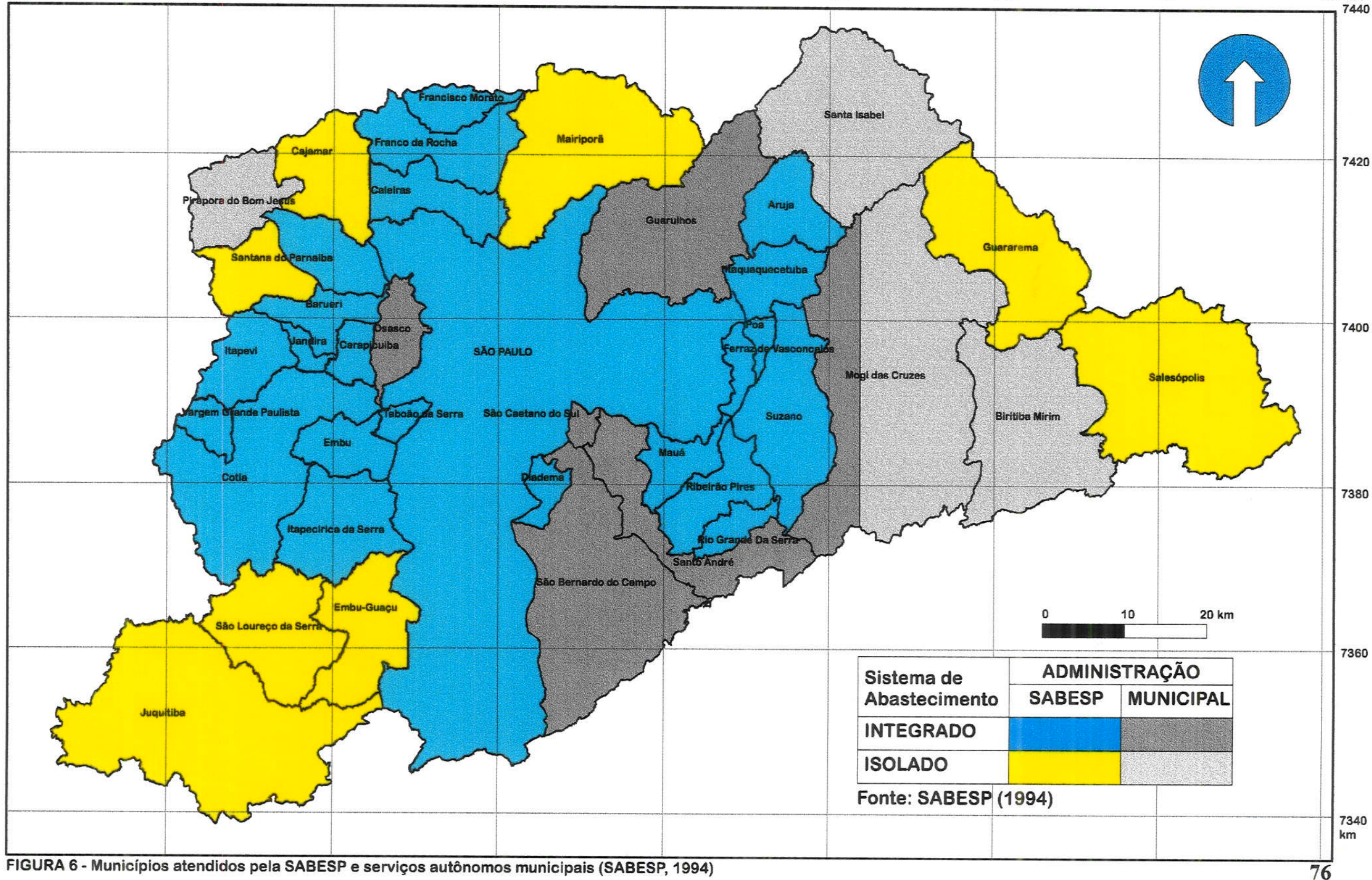




\subsubsection{Quantidade}

O abastecimento de água na RMSP é feito através do denominado Sistema Integrado e por uma série de pequenos Sistemas Isolados (FIGURA 7). O Sistema Integrado consiste de um complexo conjunto de adutoras, elevatórias e reservatórios, denominado SAM - Sistema Adutor Metropolitano, que interliga os Sistemas Produtores de água tratada aos reservatórios setoriais de distribuição (FIGURA 7). O sistema Adutor Metropolitano foi concebido de forma a abranger a maior parte da área metropolitana e interligar os principais sistemas produtores da SABESP na região. Atualmente, a SABESP abastece 23 municípios através do SAM, que conduz a água tratada aos reservatórios setoriais de distribuição, e 7 municípios através de sistemas isolados. São também abastecidos através do SAM, 6 municípios que compram água por atacado da SABESP. Apenas 3 municípios possuem sistemas próprios de abastecimento, totalmente isolados, sob responsabilidade de suas administrações municipais.

O Sistema como um todo apresenta um consumo de $35.405 \mathrm{l} / \mathrm{s}$, com um déficit de 22 . $289 \mathrm{1} / \mathrm{s}$ e o índice de perda é da ordem de $37,5 \%$. As projeções futuras do consumo, da demanda e do índice de perdas estão listadas no quadro 18.

\subsubsection{Qualidade}

A CETESB através do seu Programa de Monitoramento do Estado de São Paulo monitora a qualidade das águas superficiais em 27 pontos da RMSP, conforme apresentado na figura 8.

Em cada ponto são analisados 33 parâmetros físico-químicos e bacteriológicos (QUADRO 19). Destes, somente 9 parâmetros (OD, DBO, coliformes fecais, temperatura da água, $\mathrm{pH}$, nitrogênio total, fosfato total, resíduo total e turbidez) são utilizados para calcular o Índice de Qualidade de Água (IQA) (CETESB, 1992).

A partir dos valores observados para os nove parâmetros de qualidade em uma amostra d'água, é obtida matematicamente uma "nota" que corresponde ao valor do IQA, e que varia entre 

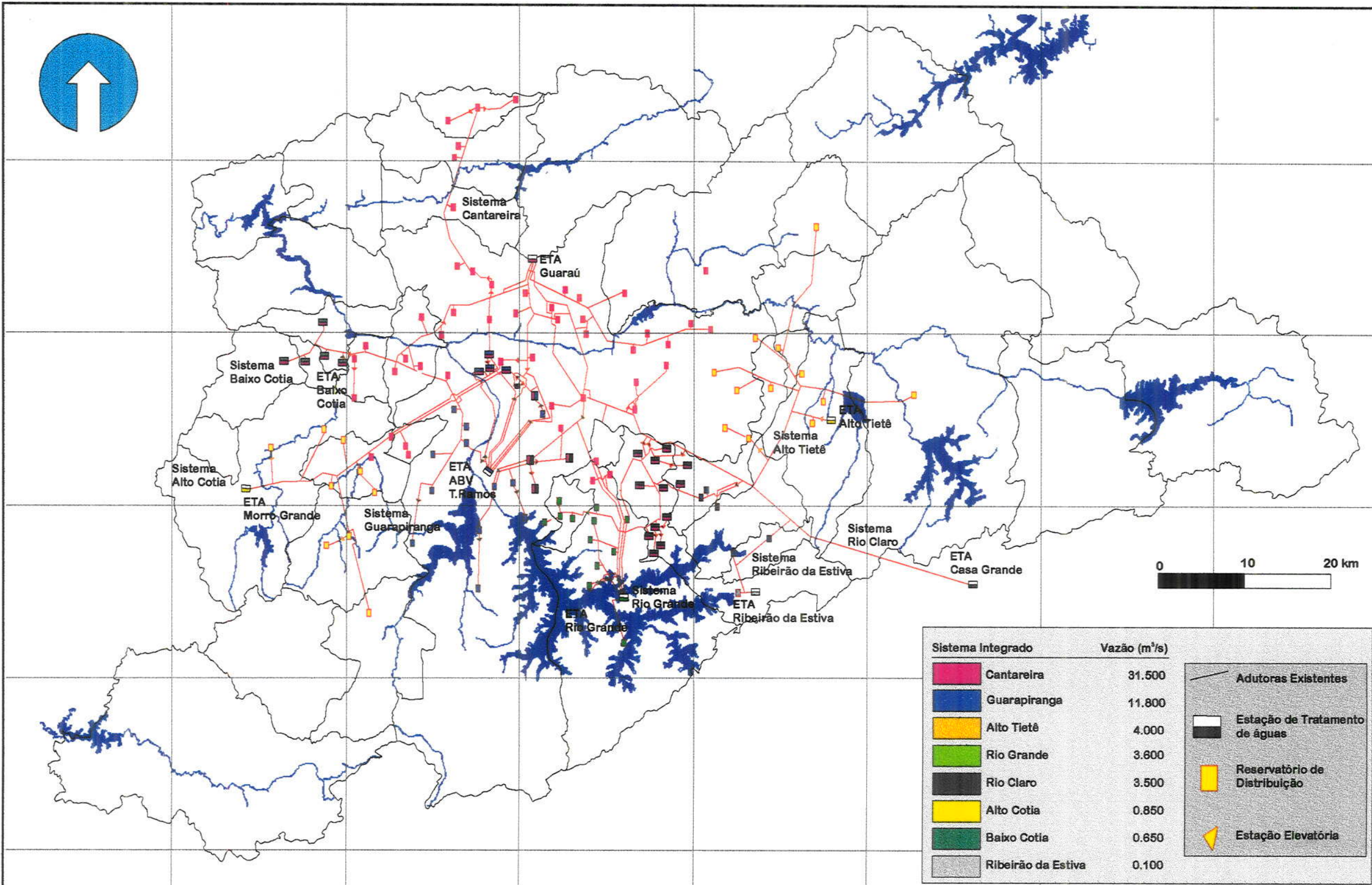
Quadro 18 - Resumo do consumo, demanda média e indices de perdas no sistema de abastecimento da RMSP (SABESP, 1995).

\begin{tabular}{|c|c|c|c|c|c|}
\hline \multicolumn{7}{|c|}{ CONSUMO (I/s) } \\
\hline Sistema/Ano & 1995 & 2000 & 2005 & 2010 & 1015 \\
\hline $\begin{array}{c}\text { SABESP - Município de } \\
\text { Såo Paulo }\end{array}$ & 26.289 & 28.899 & 31.204 & 33.269 & 35.139 \\
\hline $\begin{array}{c}\text { SABESP - Outros } \\
\text { Municipios }\end{array}$ & 3.844 & 4.594 & 5.219 & 5.748 & 6.159 \\
\hline Sistemas Isolados & 5.273 & 6.020 & 6.682 & 7.290 & 7.858 \\
\hline Total & 35.405 & 39.513 & 43.106 & 46.307 & 49.156 \\
\hline
\end{tabular}

\begin{tabular}{|c|c|c|c|c|c|}
\hline \multicolumn{7}{|c|}{ DEMANDA MEDIA (1/8) } \\
\hline SistemalAno & 1995 & 2000 & 2005 & 2010 & 1015 \\
\hline $\begin{array}{c}\text { SABESP - Municipio do } \\
\text { Săo Paulo }\end{array}$ & 42.091 & 41.792 & 42.112 & 43.000 & 44.480 \\
\hline $\begin{array}{c}\text { SABESP - Outros } \\
\text { Municipios }\end{array}$ & 6.823 & 6.013 & 7.171 & 7.472 & 7.797 \\
\hline Sistemas Isolados & 8.780 & 9.095 & 9.458 & 9.909 & 10.475 \\
\hline Total & 57.694 & 57.800 & 58.741 & 60.381 & 62.752 \\
\hline
\end{tabular}

\begin{tabular}{|c|c|c|c|c|c|}
\hline \multicolumn{7}{|c|}{ INDICE DE PERDAS (\%) } \\
\hline Sistema/Ano & 1995 & 2000 & 2005 & 2010 & 1015 \\
\hline $\begin{array}{c}\text { SABESP - Município de } \\
\text { Săo Paulo }\end{array}$ & 37,5 & 30,9 & 25,9 & 22,6 & 21,0 \\
\hline $\begin{array}{c}\text { SABESP - Outros } \\
\text { Municipios }\end{array}$ & 43,7 & 33,5 & 27,2 & 23,1 & 21,0 \\
\hline Sistemas Isolados & 39,9 & 33,8 & 29,3 & 26,4 & 25,0 \\
\hline
\end{tabular}




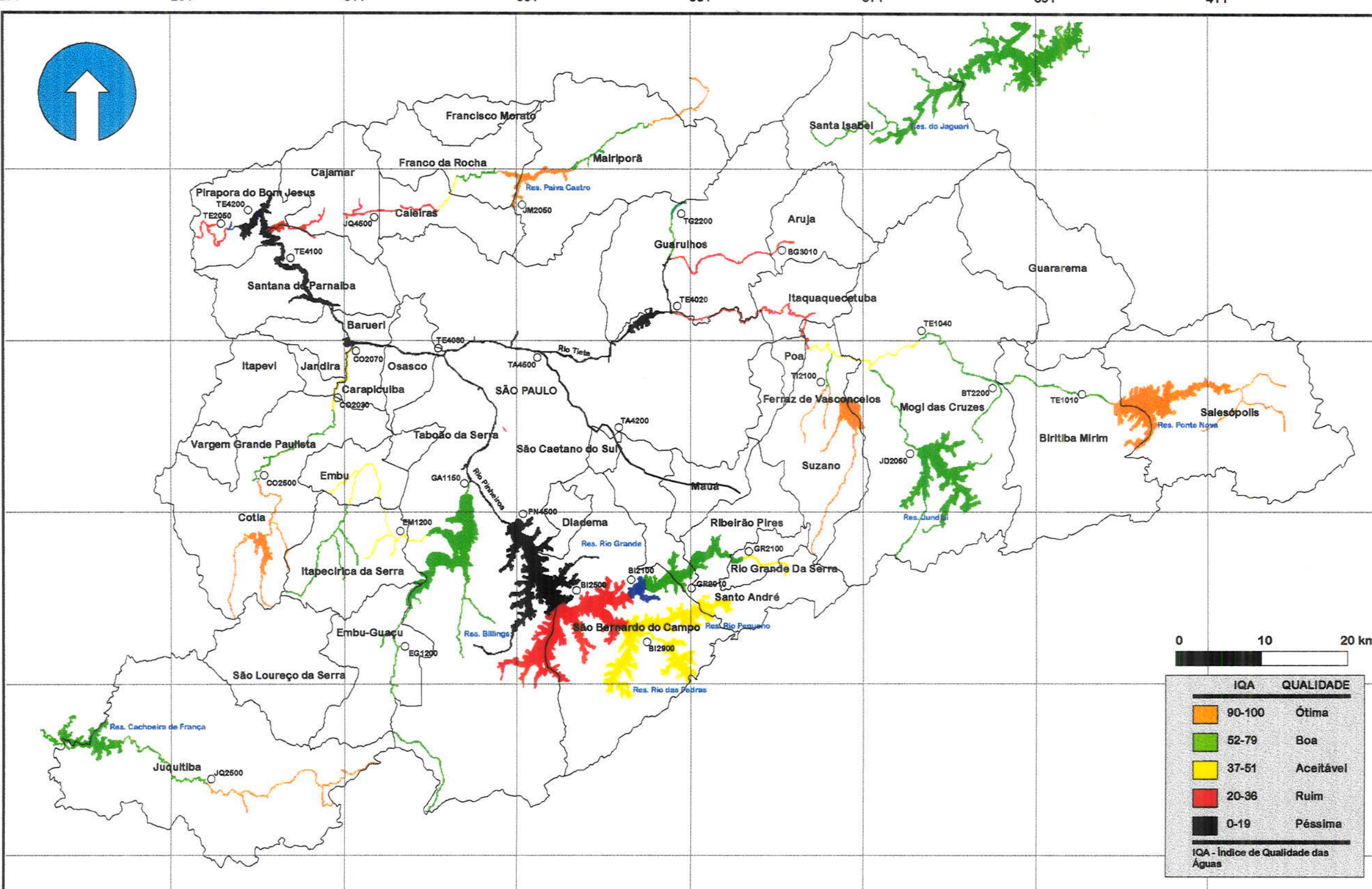


Quadro 19 - Parâmetros analisados na rede de monitoramento da CETESB (CETESB, 1992)

\begin{tabular}{|l|l|}
\hline \multicolumn{2}{|c|}{ Parâmetros Fisico-Químicos e Bacteriológicos } \\
\hline Temperatura da água & $\mathrm{pH}$ \\
\hline Oxigénio Dissolvido (OD) & Nitrogénio Total \\
\hline Coliformes Fecais & Resíduo Total \\
\hline Fosfato Total & Nitrogénio Nitrato \\
\hline Bário & Nitrogénio Nitrito \\
\hline Cádmio & Nitrogênio Amoniacal \\
\hline Chumbo & Nitrogênio Kjedahl \\
\hline Cobre & Resíduo Năo Filtrável \\
\hline Cromo & Coloraçăo \\
\hline Mercúrio & Temperatura do Ar \\
\hline Zinco & Ferro \\
\hline Fenol & Niquel \\
\hline Coliformes Totais & Demanda Química de Oxigênio (DQO) \\
\hline Manganés & Demanda Bioquímica de Oxigénio (DBO) \\
\hline Surfactantes & Ortofostato solúvel \\
\hline Condutividade Especifica & Turbidez \\
\hline
\end{tabular}


1 e 100. A aptidão que as águas brutas apresentam para serem utilizadas na produção de água potável, pode ser classificada a partir do IQA, segundo a gradação a seguir: 0-19=péssima; 2036=ruim; 37-51=aceitável; 52-79=boa; 80-100=ótima.

A classificação conforme o IQA dos pontos de amostragem da RMSP para o ano de 1992 estão representados no quadro 20 e são apresentados em forma de mapa na figura 8.

\subsection{2. Águas subterrâneas}

O uso das águas subterrâneas para o abastecimento público na RMSP é mais restrito que a água superficial. Assim, nos ítens que se seguem é descrita, de uma forma genérica, a questão da quantidade e qualidade das águas subterrâneas nos principais aqüíferos.

\subsubsection{Quantidade}

$\mathrm{Na}$ RMSP existem dois tipos de aquiferos, o sedimentar e o cristalino. $O$ aquífero sedimentar é constituído pelos sedimentos terciários da Bacia de São Paulo e por aluviões recentes. Hidrogeologicamente, ele é considerado de extensão limitada, heterogêneo, granular, descontínuo, anisotrópico, e livre a localmente semi-confinado. A capacidade específica média dos poços profundos no aquífero sedimentar, conforme estudos do DAEE (1975), é da ordem de 1,6 $\mathrm{m}^{3} / \mathrm{h} / \mathrm{m}$. Entretanto, vale ressaltar que $50 \%$ dos poços apresentam um valor de capacidade específica igual ou inferior a $0,3 \mathrm{~m}^{3} / \mathrm{h} / \mathrm{m}$. A vazão média dos poços é da ordem de $18 \mathrm{~m}^{3} / \mathrm{h}$, podendo atingir até $120 \mathrm{~m}^{3} / \mathrm{h}$, sendo que metade deles apresenta vazão igual ou inferior a 8,5 $\mathrm{m}^{3} / \mathrm{h}$.

$\mathrm{O}$ aquífero cristalino é constituído pelas rochas ígneas e metamórficas aflorantes no entorno da Bacia Sedimentar de São Paulo. O aquífero cristalino pode ser dividido em duas partes. A primeira constituída pela zona de rocha alterada saturada, e a segunda formada pela zona de rocha sã e fissurada em profundidade. Assim, o cristalino é considerado como um aqüífero heterogêneo, descontínuo, anisotrópico, livre a semi-confinado, com porosidade de fissuras, ou mesmo granular em zonas de rocha alterada. As rochas cristalinas não constituem, em si, camadas 
Quadro 20 - Índice de qualidade da água na RMSP (CETESB, 1992)

\begin{tabular}{|c|c|c|c|c|c|c|c|c|c|c|c|c|}
\hline Ponto Amost/ Meses & Jan & Fev & Mar & $\overline{A b r}$ & Mai & Jun & Jul & Ago & Set & Out & Nov & Dez \\
\hline BT2200-R. Birit. Miri & 77 & - & 65 & $=$ & - & - & 68 & 80 & - & - & 56 & - \\
\hline JD2050-Rio Jundiaí & 77 & - & 82 & - & - & $=$ & 75 & 85 & 84 & $=$ & 84 & - \\
\hline TE1010-Rio Tieté & 58 & - & 65 & - & - & - & 58 & 88 & 87 & - & 67 & - \\
\hline TE1040-Rio Tietes & 74 & $\overline{-}$ & 70 & - & - & - & 61 & 75 & 74 & - & 61 & - \\
\hline TI2100-Rio Taiaçu. & 88 & - & 89 & - & $=$ & - & 90 & 84 & 89 & $=$ & 85 & - \\
\hline BG 3010-R.Bar-Guaç & 49 & - & 45 & - & $\overline{-}$ & 52 & 23 & - & 35 & - & $\overline{-}$ & 24 \\
\hline JM2050-Res. Juqueri & 86 & - & 71 & - & 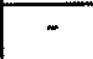 & 85 & 81 & - & 87 & - & - & 85 \\
\hline JQ2500-Rio Juqueri & 23 & - & 22 & - & - & 31 & 20 & - & 22 & - & - & 18 \\
\hline PN4500-Rio Pinheir & 21 & - & 14 & - & $\overline{-}$ & - & - & 14 & 13 & - & 19 & - \\
\hline TA4200-Rio Tamand. & 15 & - & 17 & - & - & 15 & 14 & - & 14 & - & 13 & - \\
\hline TA4500-Rio Tamand. & 13 & $\overline{-}$ & 13 & - & - & 11 & 13 & - & 14 & - & - & 14 \\
\hline TE4020-Rio Tieté & 25 & - & 27 & - & - & - & 14 & 12 & 28 & - & 24 & - \\
\hline TE4080-Rio Tietê & 15 & - & 15 & $\overline{-}$ & - & 15 & 10 & - & 16 & - & 22 & - \\
\hline TE4100-Bar.Ed Souz & 20 & - & 25 & - & - & 17 & 12 & - & 21 & - & 15 & - \\
\hline TE4200-Bar. Pirapo. & 26 & $\overline{-}$ & 17 & - & - & 29 & 13 & - & 18 & - & 18 & - \\
\hline TG2200-Res.T.Grand & 89 & - & 85 & - & - & 92 & 78 & - & 64 & - & - & 86 \\
\hline BI2100-Res. Billings & 84 & - & 75 & - & - & 91 & 65 & - & $\overline{-}$ & - & 72 & - \\
\hline BI2500-Res. Billings & 45 & - & 43 & - & $=$ & - & 32 & 33 & 21 & - & 56 & - \\
\hline B12900-Res. Billings & 53 & - & 54 & $=$ & - & - & 57 & 71 & 43 & - & 54 & - \\
\hline GR2010-Res.R.Gran & 78 & $\sim$ & 80 & - & - & 57 & 80 & - & - & - & 57 & - \\
\hline GR2100-R.Gran/. & 32 & - & 43 & $=$ & - & 57 & 37 & - & - & - & 46 & - \\
\hline CO2030-Rio Cotia & 52 & - & 59 & - & - & 47 & 52 & - & 44 & - & 56 & - \\
\hline CO2070-Rio Cotia & 57 & - & 62 & - & - & 66 & 62 & - & $\overline{-}$ & - & 44 & - \\
\hline CO2500-Bar. Graças & 75 & - & 85 & 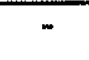 & - & 87 & 87 & - & 77 & - & 54 & - \\
\hline EG1200-R.Em-Guaç & 66 & - & 57 & 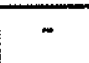 & - & 71 & 69 & - & - & - & 61 & - \\
\hline EM1200-R. Em-Mirim & 62 & - & 54 & 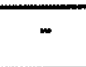 & - & 67 & 59 & - & - & - & 51 & - \\
\hline GA1150-Res. Guarap & 90 & - & 66 & - & - & 88 & 88 & - & - & - & 76 & $\overline{-}$ \\
\hline
\end{tabular}


aquíferas, e somente ao longo de lineamentos estruturais como falhamentos, fraturas e contatos entre diferentes litologias ou corpos intrusivos, apresentam condições de ocorrência de água subterrânea em regime de porosidade de fissuras. A capacidade específica média dos poços profundos no aquífero cristalino, conforme o estudo do DAEE (1975), é de $0,34 \mathrm{~m}^{3} / \mathrm{h} / \mathrm{m}$, variando de 0,06 a $0,7 \mathrm{~m}^{3} / \mathrm{h} / \mathrm{m}$. Entretanto deve-se notar que $80 \%$ dos poços apresentam um valor de capacidade específica igual ou inferior à média. A vazão média dos poços é da ordem de $7 \mathrm{~m}^{3} / \mathrm{h}$, podendo atingir até $90 \mathrm{~m}^{3} / \mathrm{h}$, no entanto metade deles apresenta vazão igual ou inferior a $2 \mathrm{~m}^{3 / h}$.

Segundo estudos realizados pelo CEPAS (1994), as potencialidades das águas subterrâneas de uma área compreendem três tipos principais de reservas: permanente ou estática, reguladora ou dinâmica e explotável ou disponível. Para a RMSP, as 3 categorias de reservas estão apresentadas no quadro 21. O estudo de águas subterrâneas do DAEE (1975) estimou a existência de 4.000 poços tubulares ativos e cerca de 40.000 poços escavados. Os volumes de água extraídos pelos poços tubulares foram avaliados em 39 milhões de $\mathrm{m}^{3} /$ ano do aquífero sedimentar, 23 milhóes de $\mathrm{m}^{3} /$ ano do aquífero cristalino e 40 milhões $\mathrm{m}^{3} /$ ano por poços rasos escavados nos dois domínios. A vazão total de água subterrânea extraída (102 milhões de $\mathrm{m}^{3} / a n$, ou $3,2 \mathrm{~m}^{3} / \mathrm{s}$ ) correspondia a cerca de $16 \%$ do volume total de água fornecida pelo sistema público, da ordem de $20 \mathrm{~m}^{3} / \mathrm{s}$.

Quadro 21 - Potencialidades e disponibilidade de água subterrânea na RMSP (CEPAS, 1994)

\begin{tabular}{|l|c|c|}
\hline RESERVAS/AQUIFEROS & SEDIMENTAR & CRISTALINO \\
\hline PERMANENTE(Milhóes $\mathrm{M}^{3}$ ) & 8.857 & 9.898 \\
\hline REGULADORA(Milhões $\mathrm{M}^{3}$ ) & 898 & 2.343 \\
\hline DISPONIVEL(Milhð̌es $\mathrm{M}^{3}$ ) & 224 & 586 \\
\hline DISPONIB. ESPEC.(L/s. $\mathrm{km}^{2}$ ) & 4,8 & 2,7 \\
\hline
\end{tabular}

Segundo CEPAS (1994), existem atualmente na RMSP cerca de 6.000 poços tubulares em operação explorando os dois aquíferos. Estes estariam atualmente explorando cerca de 203 milhôes de $\mathrm{m}^{3} / \mathrm{ano}$, ou $6,37 \mathrm{~m}^{3} / \mathrm{s}$. Este valor representa $17,9 \%$ do volume total de água fornecida pela SABESP atualmente, que é da ordem de $35,5 \mathrm{~m}^{3} / \mathrm{s}$. 


\subsubsection{Qualidade}

Conforme CEPAS (1994), as águas obtidas de poços que captam as zonas aquíferas das rochas cristalinas e sedimentares na RMSP têm, em geral, excelente qualidade para consumo. Os valores de condutividade específica variam entre 24 e $996 \mathrm{mSiemens} / \mathrm{cm}$. O pH varia entre 4,7 e 8,9, com predominância de valores entre 5 e 6 . Os sólidos totais dissolvidos (STD) são, em geral, inferiores a $250 \mathrm{mg} / \mathrm{l}$, com predominância dos valores inferiores a $100 \mathrm{mg} / \mathrm{l}$. Quanto à composição química, predomina o tipo bicarbonatada cálcica, característico de águas de circulação rápida.

Para as águas subterrâneas não existe uma rede de monitoramento da qualidade implantada como para as águas superficiais. Assim, CEPAS (1994) sugere que sejam implantados dois niveis principais de rede de monitoramento da qualidade da água subterrânea: monitoramento da qualidade natural das águas subterrâneas e monitoramento de fontes potenciais ou reais de poluição.

7.3. Diagnóstico das áreas de disposição de resíduos

As informações apresentadas neste ítem referem-se às 116 áreas de disposição existentes na RMSP (CETESB, 1997). Os dados apresentados neste ítem correspondem às informações provenientes do cadastro de áreas contaminadas da CETESB/GTZ. A partir destas informações foi possivel descrever o cenário atual dos locais de disposição de resíduos sólidos e suas adjacências.

\subsubsection{Produção de resíduo sólido doméstico}

A RMSP com uma população de 15.902 .412 habitantes gera cerca de 12.826 toneladas de resíduos domésticos por dia, considerando-se uma produção média de $850 \mathrm{~g}$ de lixo por pessoa por dia. Na tabela 9 apresenta-se valores referentes à geração de massa de resíduo por município por dia. 
Tabela 9. Tabela com volume estimados de resíduos por município da RMSP

\begin{tabular}{|c|c|c|c|c|c|}
\hline Município & Populaça & Volume Residuos & Município & Populaçăo & Volume Resíduos \\
\hline Aruja & 42.312 & $35.965,2$ & Ferraz Vasc. & 104.745 & $89.033,3$ \\
\hline Barueri & 139.928 & $118.938,8$ & Franc. Morat & 99.445 & $84.528,3$ \\
\hline Biritiba-Mirim & 18.518 & $15.740,3$ & Franco Roch & 92.750 & $78.837,5$ \\
\hline Caieiras & 41.806 & $35.535,1$ & Guararema & 18.479 & $15.707,2$ \\
\hline Cajamar & 35.863 & $30.483,6$ & Guarulhos & 830.056 & $705.547,6$ \\
\hline Carapicuiba & 301.486 & $256.263,1$ & Itapec. Serra & 91.300 & $77.605,0$ \\
\hline Cotia & 118.937 & $101.096,5$ & Itapevi & 120.459 & $102.390,2$ \\
\hline Diadema & 317.509 & 269.882 .7 & Itaquaquec. & 187.181 & $159.103,9$ \\
\hline Embu & 167.523 & $142.394,6$ & Jandira & 67.944 & $57,752,4$ \\
\hline Embu-Guacu & 38.871 & $33.040,4$ & Juquitiba & 21.364 & $18.159,4$ \\
\hline
\end{tabular}

\begin{tabular}{|c|c|c|c|c|c|}
\hline Municipio & Populacáa & Volume Residuos & Municipio & Populaciao & Volume Residuos \\
\hline Mairipora & 42.288 & $\begin{array}{r}35.944,8 \\
\end{array}$ & Sant. Parnaí. & 46.602 & $39.611,7$ \\
\hline Mauá & 310.478 & $263.906,3$ & Santo André & 619.904 & $526.918,4$ \\
\hline Mogi Cruzes & 286.055 & $243.146,8$ & S. Ber. Cam & 587.854 & $499.675,9$ \\
\hline Osasco & 579,110 & $492.243,5$ & S. Caet. Sul & 145.501 & $123.675,9$ \\
\hline Pirap B. Jes & 8.634 & $7.338,9$ & S. Paulo & 9.800 .997 & $8.330 .847,5$ \\
\hline Póá & 80.579 & $68.492,2$ & Suzano & 170.266 & $144.726,1$ \\
\hline Rib. Pires & 90.205 & $76.674,3$ & Tab. Serra & 170.156 & $144.632,6$ \\
\hline Rio G. Serra & 31.602 & $26.861,7$ & V. Gr. Paul. & 16.913 & $14,376,1$ \\
\hline Salesópolis & 11.382 & $9.674,7$ & S. Lour. Ser. & 8.004 & $6.803,4$ \\
\hline Santa Isabel & 39.406 & $33.495,1$ & & & \\
\hline
\end{tabular}

Em função da grande massa de resíduos gerada diariamente, os vários municípios que consituem a RMSP têm enfrentado muitos problemas ambientais, administrativos e de saúde pública. Entre esses problemas, podem ser citados: a dificuldade de selecionar locais apropriados para disposição de resíduos; conflitos de uso do solo com a população estabelecida ao redor das instalações de tratamento e destino final do lixo; exportação de lixo para municípios vizinhos, gerando resistências da população; e contaminação dos escassos recursos hídricos.

Atualmente existem na RMSP 116 áreas cadastradas de disposição de resíduos sólidos, ativas e encerradas, sem considerar as áreas de "bota-foras". Deste total apenas 20 áreas são consideradas aterros sanitários ou aterro controlados. O restante, 96 áreas, são lixões onde não foram consideradas a avaliação dos impactos ambientais, aspectos construtivos ou a questão da saúde pública.

\subsubsection{Localização das áreas de disposição}

A localização das 116 áreas encontra-se apresentada na figura 9. Nela observa-se que a maior parte dos locais de disposição concentra-se nas porções limítrofes entre São Paulo e municípios vizinhos, nas porções norte, leste e oeste. A porção sul, possue poucas áreas em 


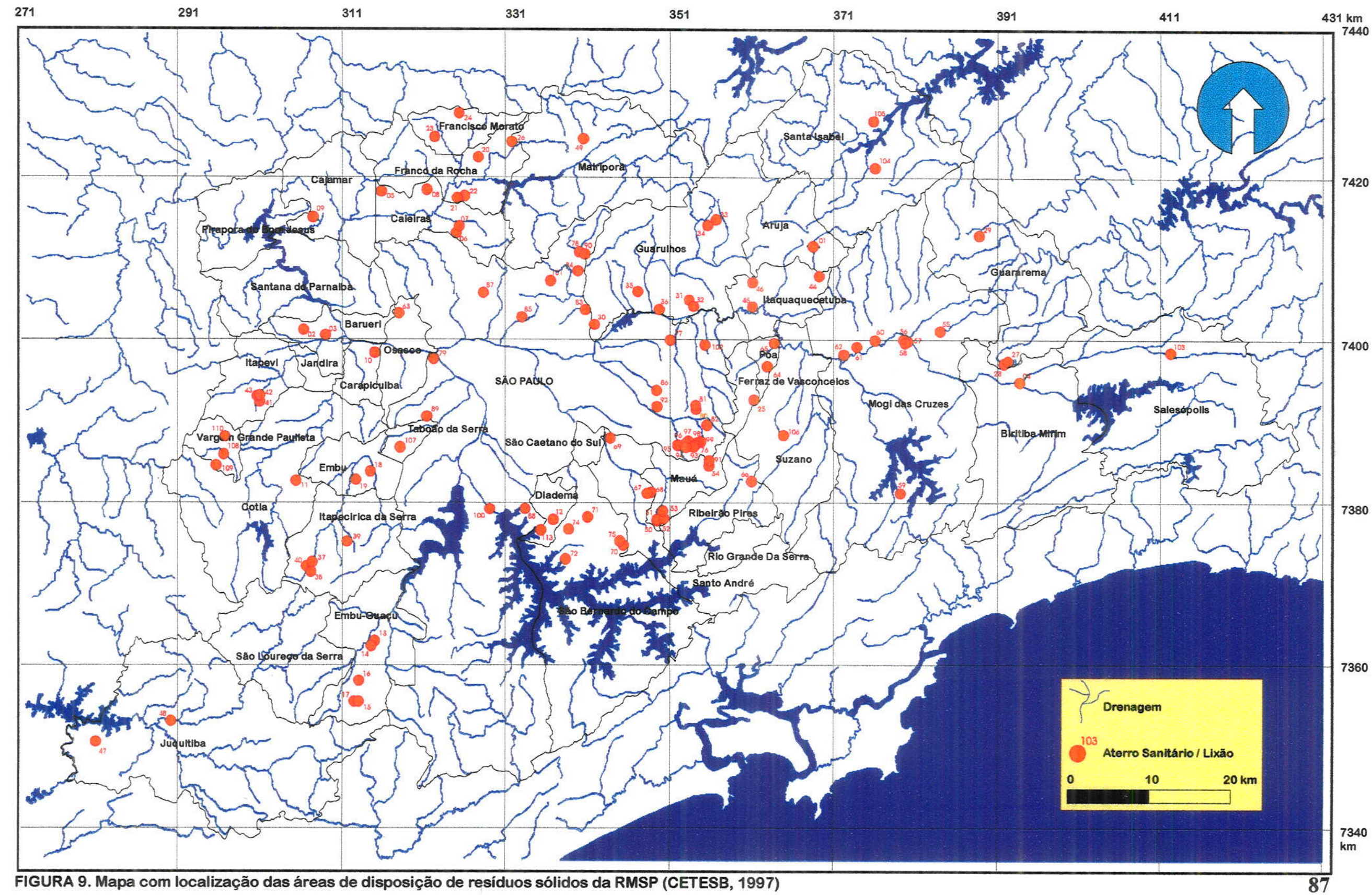


função da existência da Área de Proteção de Mananciais (Billings e Guarapiranga) e Área de Proteção Ambiental (Serra do Mar).

Estas 116 áreas de disposição somadas ocupam uma superfície aproximada de $20 \mathrm{~km}^{2}$, e um volume estimado correspondente a aproximadamente 100 milhões de $\mathrm{m}^{3}$.

7.3.3. Morfologia do terreno e ocupação no local de disposição e áreas adjacentes

A forma de disposição dos resíduos nas diferentes áreas ocorre em diferentes condições de morfologia do terreno. A morfologia predominante nestas áreas são encostas e vales que somam $59,3 \%$ do total (69 áreas). Além destas morfologias existem outras formas, conforme apresentado na tabela 10. Uma situação particular são as cavas de mineração que são preenchidas com resíduos e que representam $14,7 \%$ do total de áreas (17 áreas). Nestas áreas, a maior preocupação, sem dúvida, é o contato direto das águas subterrâneas com as substâncias originárias do resíduo e/ou o próprio resíduo.

Tabela 10. Morfologia do terreno nas áreas de disposição

\begin{tabular}{c|c|c}
\hline Morfologia do terreno & Número de áreas & $\%$ \\
\hline Topo & 6 & 5,2 \\
\hline Encosta & 22 & 19,0 \\
\hline Vale & 24 & 20,6 \\
\hline Topo + Encosta & 9 & 7,8 \\
\hline Topo + Encosta + Vale & 4 & 3,5 \\
\hline Encosta + Vale & 23 & 19,7 \\
\hline Cava de Mineração & 17 & 14,7 \\
\hline Sem Informação & 11 & 9,5 \\
\hline
\end{tabular}

A RMSP encontra-se densamente ocupada conforme descrito no item anterior. Este fato tem causado o avanço da ocupação humana nas regiốes periféricas dos municípios, onde normalmente encontram-se instaladas as áreas de disposição de resíduos. A figura 10, através do gráfico e quadro, ilustra a proximidade da ocupação humana em relação às áreas de disposição. Em $50 \%$ dos casos (50 áreas) a ocupação encontra-se a uma distância menor que 50 metros dos 


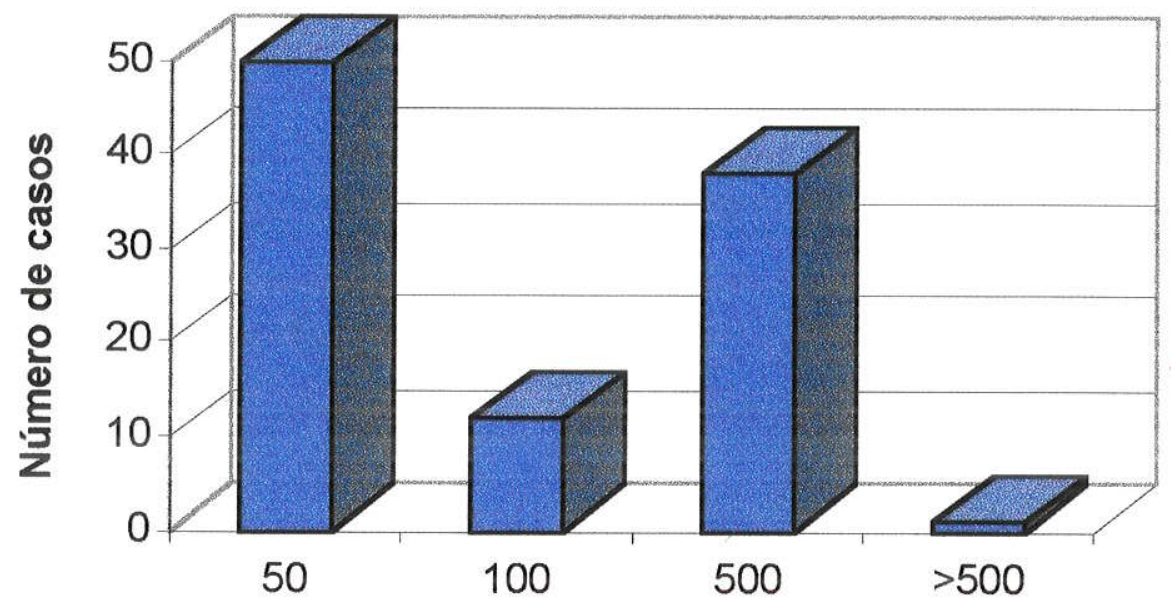

Distância da edificação próxima

\begin{tabular}{|c|c|c|c|c|}
\hline \multicolumn{5}{|c|}{ EDIFICAÇÃO PRÓXIMA (DISTÂNCIA EM METROS) } \\
\hline $0-50$ & $50-100$ & $100-500$ & $>500$ & S/ INFORMAÇÃO \\
\hline 50 & 12 & 38 & 1 & \\
\hline
\end{tabular}

FIGURA 10 - Gráfico e quadro demonstrando a distância das edificações em relação aos locais de disposição 
locais de disposição, $10 \%$ (12 áreas) entre 50 e 100 metros, 38\% (38 áreas) entre 100 e 500 metros e $2 \%$ (1 área) a uma distância maior que 500 metros. Assim, a proximidade da ocupação humana em relação aos locais de disposição tem causado sérios conflitos tanto no aspecto da saúde pública quanto da contaminação dos recursos hídricos, trazendo risco de explosão, ou ainda, problemas com menor risco como odor e proliferação de insetos e roedores.

$\mathrm{Na}$ questão da ocupação humana, os problemas sociais que envolvem os locais de disposição não se restrigem apenas às áreas adjacentes mas também às pessoas que sobrevivem do lixo selecionando materiais recicláveis e comercializáveis. Em muitas áreas, estas pessoas denominadas de "catadores", chegam a construir casas provisórias (barracos) e moram no próprio local de disposição de resíduos.

Na figura 11 o gráfico e o quadro demonstram a existência de catadores nos locais de disposição. Em 59\%(69) das áreas não foi observada a presença de catadores, em 13\% (15) das áreas registram-se poucos catadores (de 5 a 10 pessoas), em $16 \%(19)$ das áreas verificam-se de 10 a 50 catadores e em $4 \%$ (5) das áreas com mais de 50 catadores. Assim, observa-se que, em pelo menos 39 áreas existem catadores que sobrevivem do material retirado do local de disposição.

\subsubsection{Local de disposição e o contexto hidrogeológico}

As 116 áreas de disposição de resíduos sólidos da RMSP encontram-se inseridas dentro do contexto hidrogeológico anteriormente mencionado, onde distinguem-se basicamente dois tipos de aquíferos: o sedimentar e o cristalino. $O$ aquífero sedimentar é constituído principalmente pelos sedimentos terciários e quaternários e o aquífero cristalino de rochas ígneas e metamórficas pré-Cambrianas.

Do total de 116 áreas de disposição de resíduos apenas 101 áreas possuem informação sobre o contexto hidrogeológico em que se encontra inserido. A figura 12 se apresenta uma ilustração das 9 situações de contexto hidrogeológico possíveis de serem encontradas na RMSP, e estas, por sua vez, associadas ao número de locais de disposição de resíduos. Notadamente, existe uma associação entre tipos litológicos e o tipo de circulação das águas subterrâneas.

Nas 101 áreas que possuem informações sobre a litologia, apenas 24 locais estão sobre aquífero sedimentar e os 77 locais restantes sobre o aquífero cristalino. Entre os locais situados sobre o aquífero sedimentar 22 estão sobre o quaternário e 2 sobre o terciário em área de recarga. 


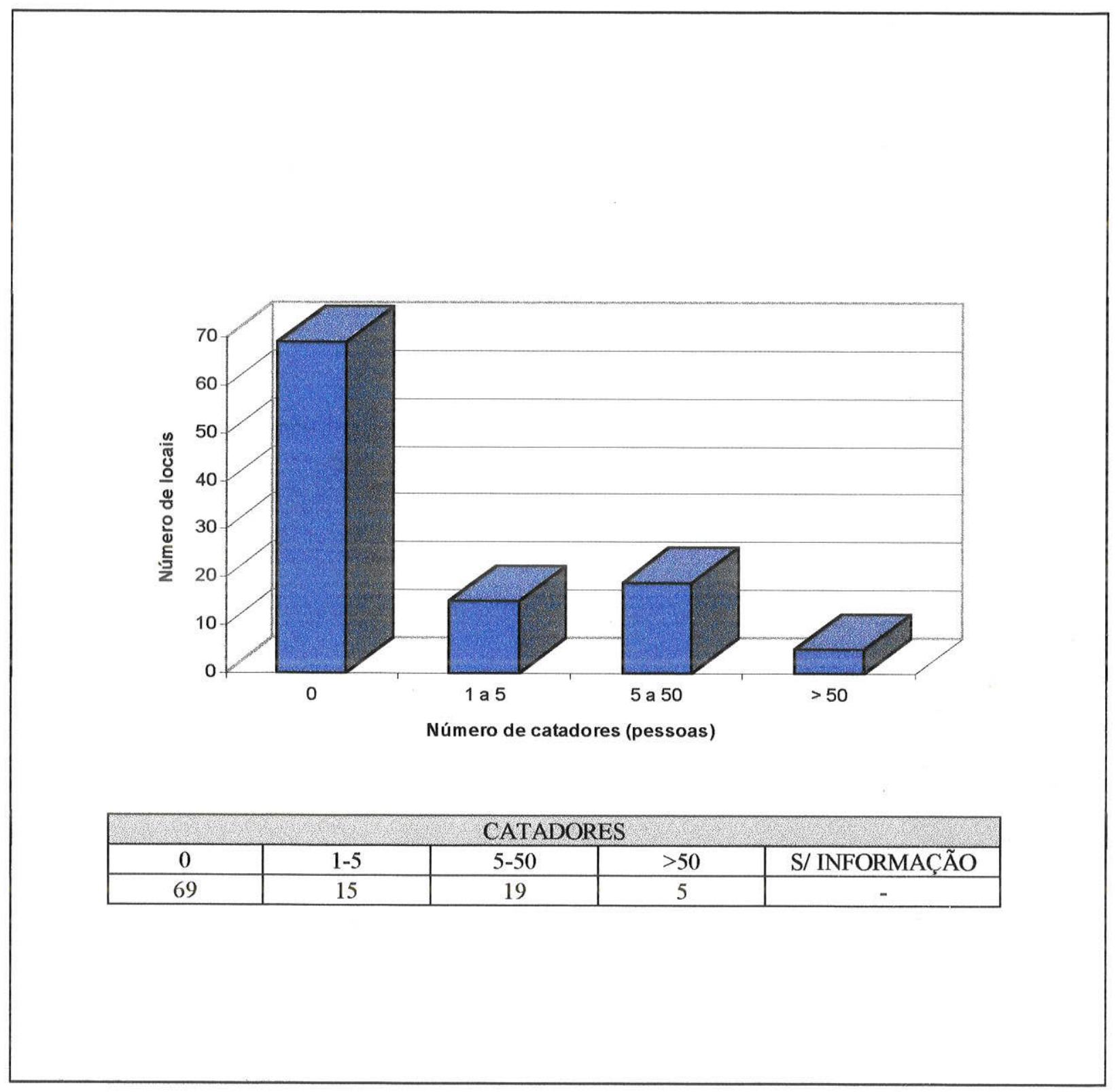

FIGURA 11 - Gráfico e quadro demonstrando a existência de catadores nos locais de disposição. 


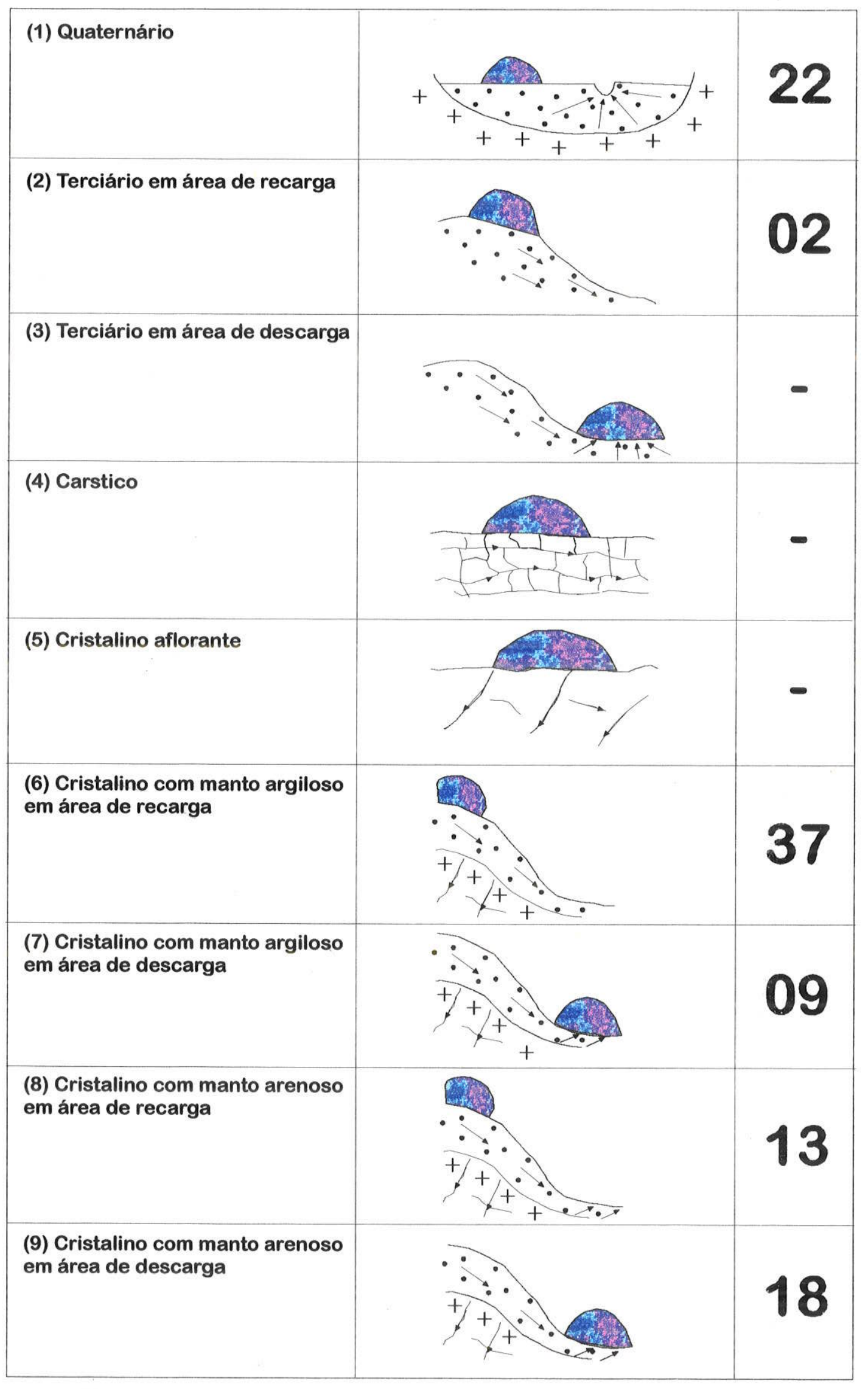

FIGURA 12 - Quadro resumo ilustrativo do contexto hidrogeológico da RMSP associados ao número de locais de disposição de resíduos 
No restante das áreas que estão sobre o aquífero cristalino, 37 locais estão sobre rochas cristalinas com manto argiloso em área de recarga, 9 sobre cristalino com manto argiloso em área de descarga, 13 sobre cristalino com manto arenoso em área de recarga e 18 sobre cristalino com manto arenoso em área de descarga.

Da observação desses números, pode-se concluir que a maioria dos locais de disposição de resíduos estão em área de recarga, somando um total de 52 locais de disposição. Por outro lado, estas áreas situam-se em regiões periféricas das principais zonas urbanas da RMSP, que são coincidentes com as áreas de ocorrência das rochas cristalinas.

\subsubsection{Aspectos construtivos dos locais de disposição}

A forma de disposição do resíduo, seja em lixões ou em aterros, tem sido realizada de duas formas básicas: acima ou abaixo da superficie do terreno. Do total de 116 áreas cadastradas, $86 \%$ (100) das áreas os resíduos estão depositados acima da superfície do terreno e em $14 \%$ (16) abaixo da superfície do terreno.

Na Figura 13 consta um desenho esquemático com as condições ideais para a construção de aterro, minimizando os impactos ambientais nos locais de disposição de resíduos sólidos. Nestas condições, uma obra deste tipo pode ser dividida em três partes: setor em preparação, setor em execução e setor concluído.

No setor em preparação, normalmente, três condições básicas são observadas. A primeira diz respeito à profundidade do nível d'água subterrânea, que deve estar a pelo menos 2 metros de profundidade a partir da superficie inferior do aterro, conforme manual elaborado pela CETESB (1987). A segunda refere-se à camada inferior do aterro que deve ser impermeabilizada, conforme a mesma norma. Os materiais que podem ser utilizados podem ser tanto sintéticos como argila natural. A terceira condição refere-se à drenagem de coleta de chorume, que deve ser instalada sobre a camada impermeabilizante.

No levantamento das 116 áreas de disposição observou-se que o nível d'água varia até a máxima profundidade de 50 metros.

Na RMSP observa-se que, pelo menos em $31 \%$ (36) das áreas a situação é crítica, apresentando o nível d'água muito próximo da superficie, entre 0 e 5 metros, 46\% (53) das áreas apresentam-se em situação razoável, com profundidade do nível d'água entre 5 e 20 metros. $O$ 




FIGURA 13 - Aspectos construtivos dos locais de disposição de resíduos sólidos (modificado de IPT, 1995) 
restante das áreas estão com a profundidade do nível d'água maior que 20 metros. Na realidade, a profundidade do nível d'água torna-se um fator crítico para a contaminação da água subterrânea em áreas de disposição de resíduos, pelo simples motivo de que as substâncias nocivas originárias do chorume têm menor distância a percorrer até atingir a zona saturada.

Ainda na figura 13, observa-se que das 116 áreas de disposição de resíduos, apenas 7 locais possuem algum tipo de impermeabilização inferior. Na prática, mesmo a maioria dessas 7 áreas possue apenas solo compactado como camada inferior impermeabilizante, diminuindo a condutividade hidráulica do terreno, porém, longe das condições técnicas ideais. Tal situação pode ser traduzida da seguinte forma: mesmo estas áreas não possuem uma verdadeira camada inferior impermeabilizante, mas sim uma obra minimizadora em relação a possível infiltração do chorume no solo.

Além da camada impermeabilizante, as drenagens de líquidos para a coleta de chorume é um outro tipo de obra que permite minimizar o efeito da infiltração do chorume no solo, e posteriormente, na água subterrânea. No universo de 116 áreas, apenas 13 locais possuem drenagens de líquidos percolados.

Considerando-se que a maioria dos locais de disposição de resíduos da RMSP não possue nem a camada inferior impermeabilizante e tampouco drenagens de líquidos, o destino final do chorume acaba sendo o solo, a água subterrânea e a água superficial, comprometendo a qualidade destes meios.

Durante a disposição dos resíduos sólidos, normalmente é realizada a cobertura operacional dos resíduos, criando-se células de lixo para evitar a proliferação de vetores e mau cheiro. Além disso são instalados drenos para gases no local de disposição, a fim de evitar possíveis explosões ou escape de gases para edificações ou áreas adjacêntes. Na RMSP apenas 23 locais de disposição possuem algum tipo de impermeabilização ou cobertura operacional, e 14 locais apresentam drenos de gases instalados. Na maioria das áreas os cuidados operacionais não existem e o risco de acidentes é considerado alto.

Dois tipos de obras de engenharia são considerados como básicos para a conclusão ou encerramento de uma área de disposição: a impermeabilização superior e instalação de drenos para água de escoamento superficial das chuvas. Ambas têm a função de impedir a infiltração da água pluviométrica para o interior da massa de lixo, e consequentemente reduzir a geração de chorume. 
No contexto da RMSP apenas 31 locais possuem impermeabilização superior e 14 áreas tem drenagem de água superficial . Dessa forma, a maioria dos locais de disposição da RMSP sofrem a influência da pluviosidade, gerando grandes volumes de chorume.

\subsection{Sistema de classificação dos locais de disposição}

Nos ítens seguintes são apresentados os dados de pontuações realizadas na RMSP, a distribuição espacial, a classificação, e finalmente, a priorização das áreas de disposição de resíduos sólidos, identificando aquelas consideradas como críticas.

\subsubsection{Preenchimento da Ficha de Pontuação}

Para as 116 áreas de disposição de resícuos domésticos apresentadas no ítem anterior, foi realizado o preenchimento da Ficha de Pontuação, tendo as Fichas Cadastrais como fontes de informações.

Os valores individuais de pontuação para cada bem a proteger e também para cada área encontram-se no Anexo 1.

Vale relembrar que, o conceito de liberação, transporte e entrada de substâncias nocivas nos bens ou recursos ambientais apresentados nó início deste trabalho, está implícito na pontuação de cada bem a proteger.

$O$ conceito de bens a proteger apresentado, refere-se especificamente aos bens ou recursos naturais que devem ser protegidos no local de disposição e/ou suas adjacências. Assim, os bens a proteger mais relevantes considerados neste trabalho são os listados abaixo:

BP1 - Saúde e vida da população

BP2 - Abastecimento público (água potável)

BP3 - Uso do solo (residências)

BP4 - Proteção das águas subterrâneas e superficiais

BP5 - Uso agrícola e pecuária 


\section{BP6 - Outros bens a proteger}

$O$ maior enfoque dado à pontuação dos bens a proteger foi para os recursos hídricos e a saúde pública. Os bens a proteger BP1, BP3 e BP5 estão relacionados com a saúde pública. $O$ BP1 trata das consequências diretas que as substâncias nocivas podem causar na população. $O$ BP3 considera o risco da população residente no entorno entrar em contato direto e/ou indireto com a substância nociva. O BP5 pondera a possibilidade da substância nociva entrar na cadeia alimentar e atingir o ser humano. Os bens a proteger BP2 e BP4 são relativos aos recursos hídricos. Por final, o BP6 contempla outros bens de interesse público, como parques, APMS, APAs e matas naturais.

\subsubsection{Distribuição espacial dos locais de disposição por pontuação}

As figuras 14 a 19 mostram a distribuição espacial das áreas de disposição de resíduos sólidos da RMSP, identificadas pelos intervalos de pontuação de: 0 a 50, 51 a 100, 101 a 200 , 201 a 300,301 a 400,401 a 500 e 501 a 600 pontos, para os bens a proteger BP1 a BP6.

Nas figuras 20 a 25 estão apresentados os valores estatísticos (mediana, média, moda, mínimo e máximo) correspondentes às pontuações obtidas pelas áreas de disposição situadas em cada município, considerando cada bem a proteger separadamente.

Em relação ao bem proteger BP1, saúde e vida da população (FIGURAS 14 e 20), pode ser observado claramente que os locais de pontuação mais baixa predominam nos municípios com baixa taxa de ocupação como Santa Isabel, Guararema, Salesópolis, Mairiporã, Francisco Morato, Franco da Rocha, Caieiras, Cajamar, Cotia e Juquitiba. Por outro lado, as áreas com pontuação alta concentram-se nos municípios com alta densidade populacional, como no município de São Paulo e nos municípios imediatamente adjacentes, ou ainda, ao longo das principais rodovias como Castelo Branco, Bandeirantes, Anhangüera, Airton Senna, Dutra, Anchieta e Imigrantes.

No caso de BP2, abastecimento público, os locais com valores de pontuação baixa e média predominam sobre os de valores altos (FIGURAS 15 e 21). Além disso, as figuras demonstram também que as áreas com pontuação alta estão distantes dos principais reservatórios. 







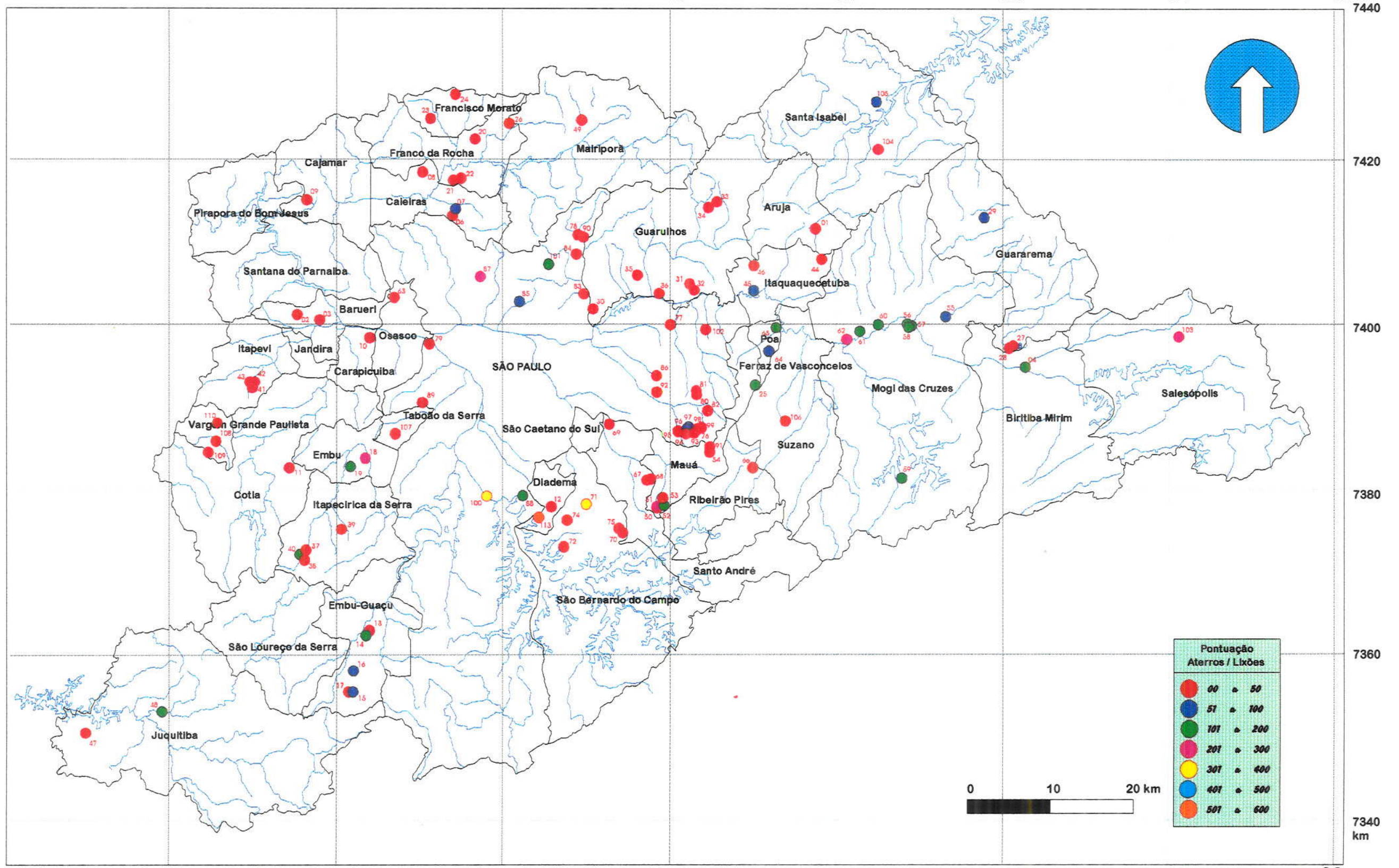














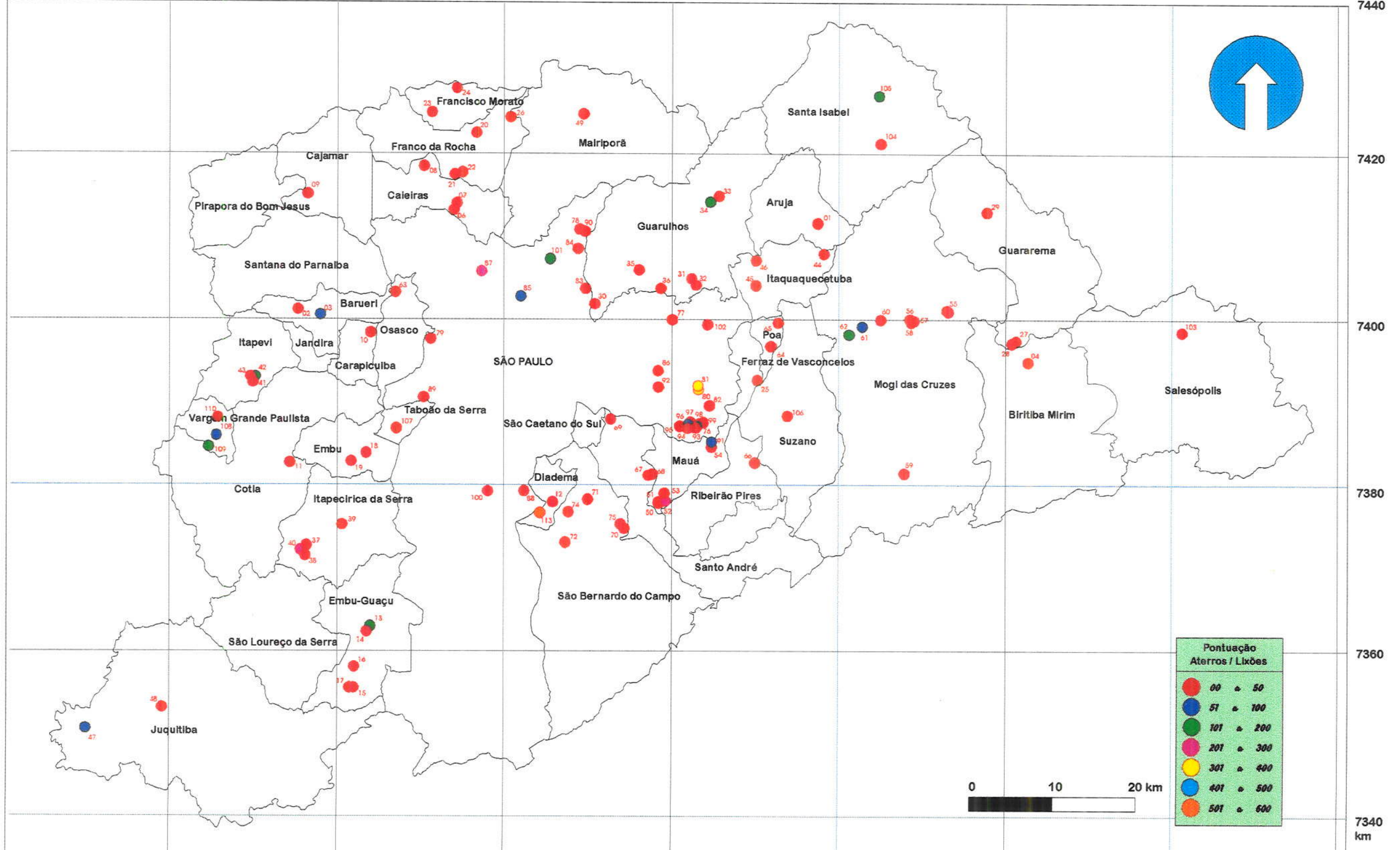




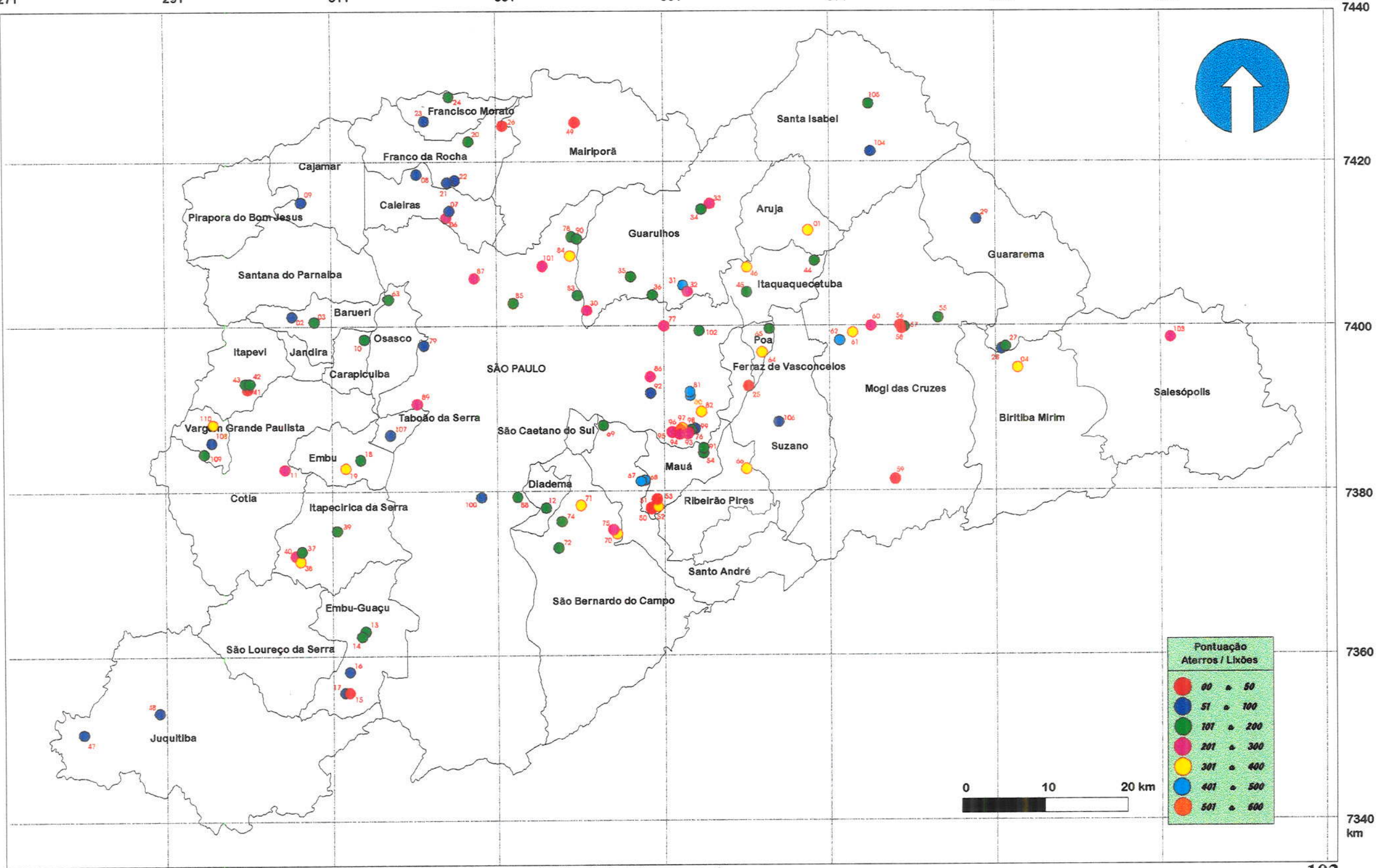




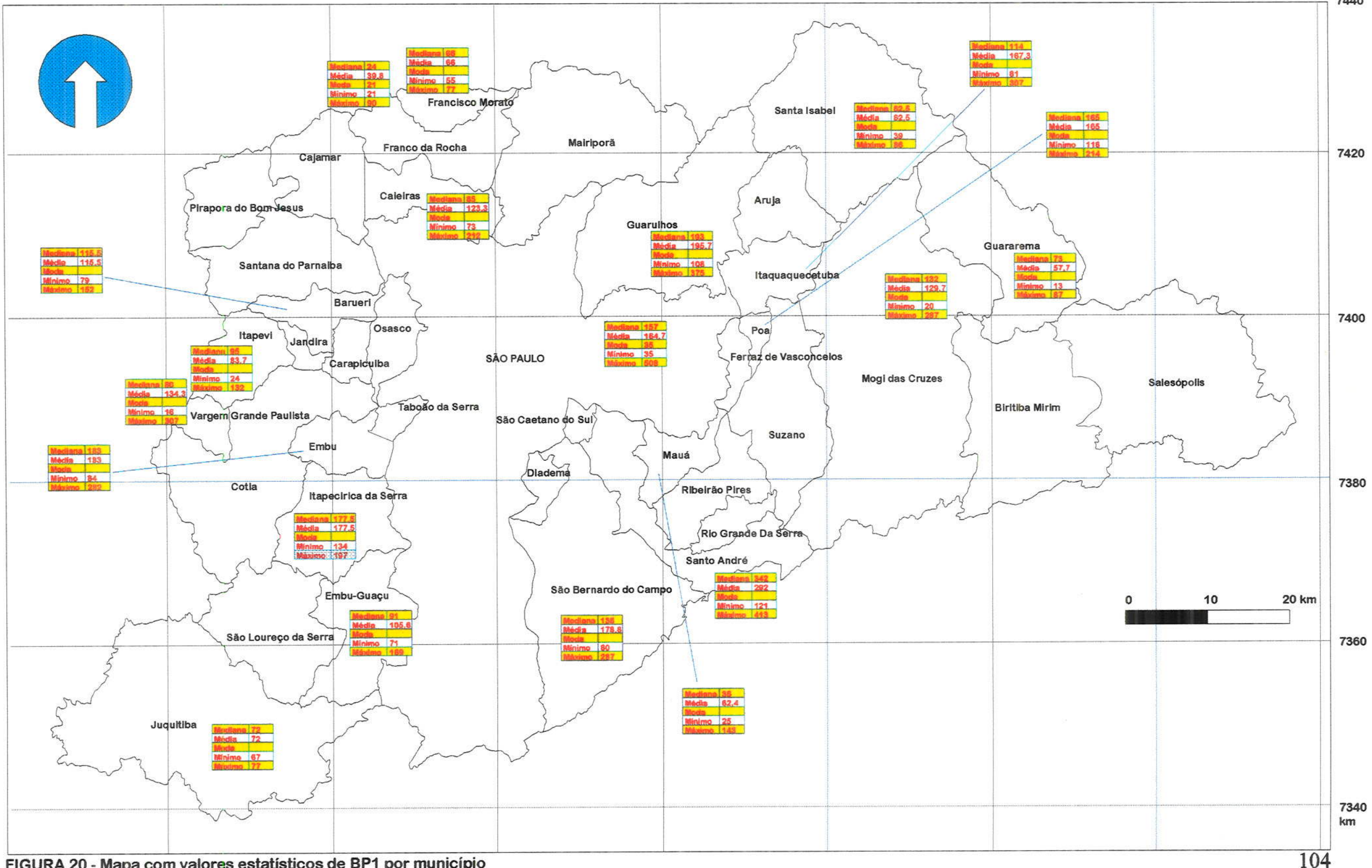




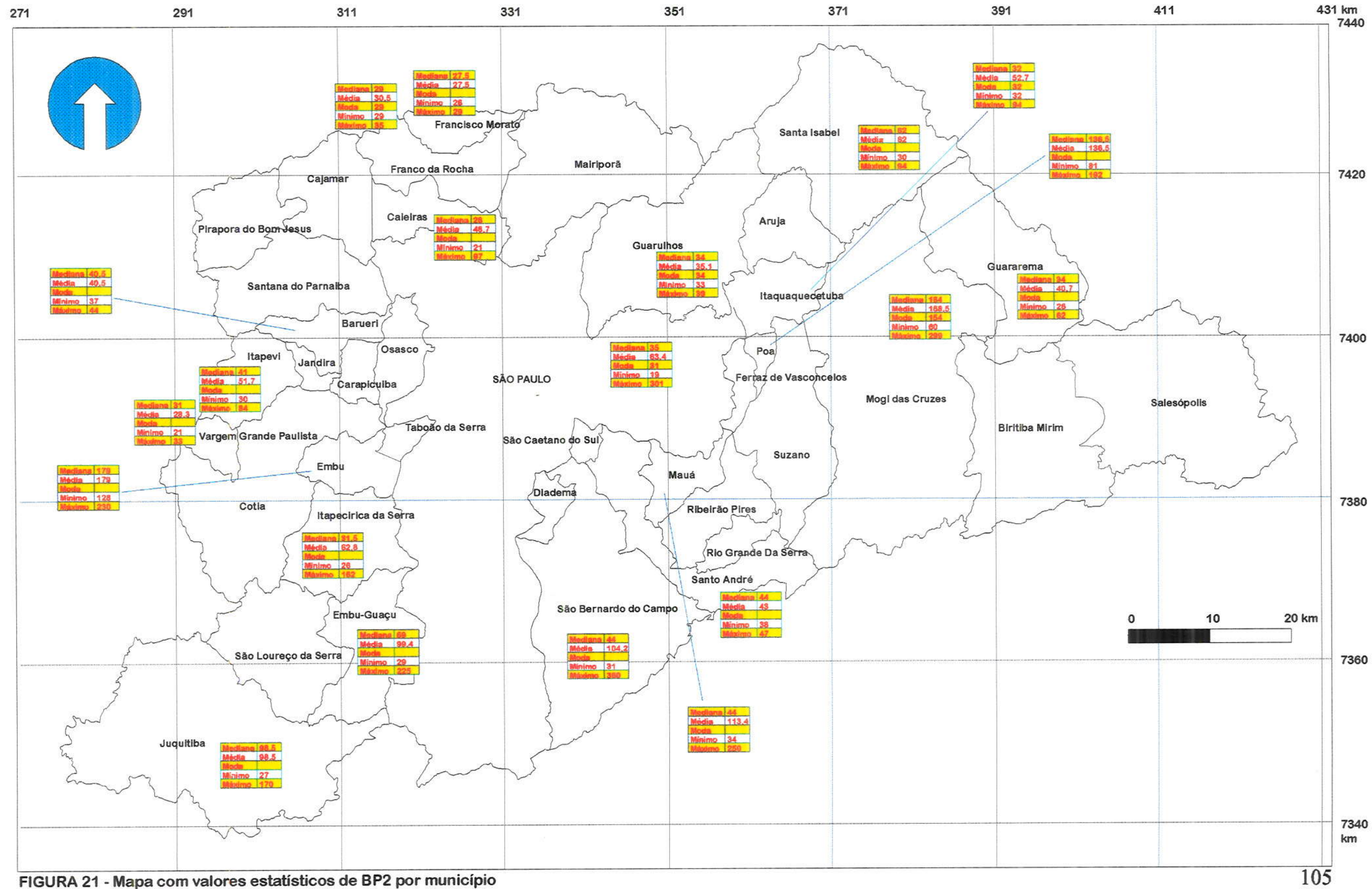




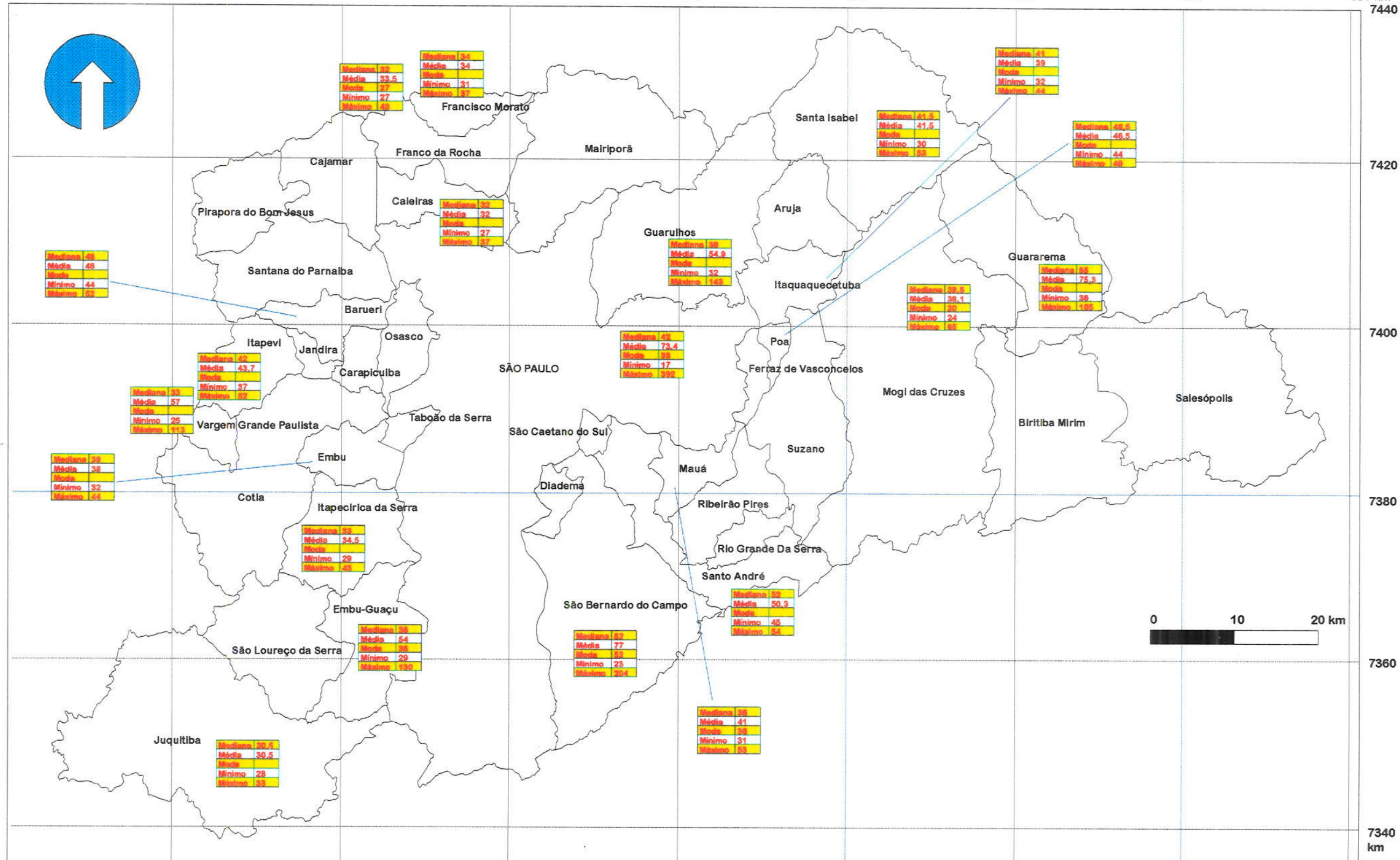




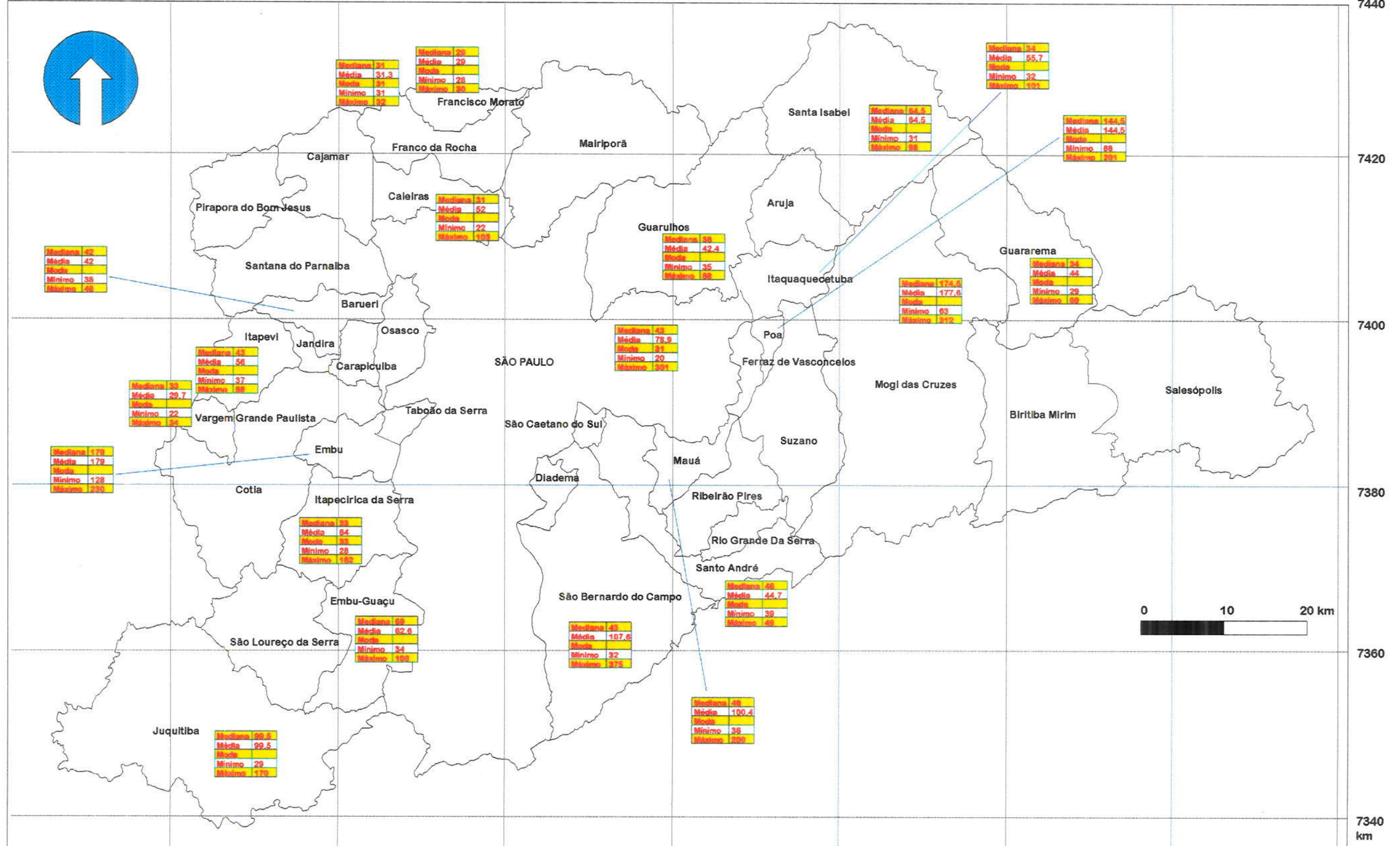




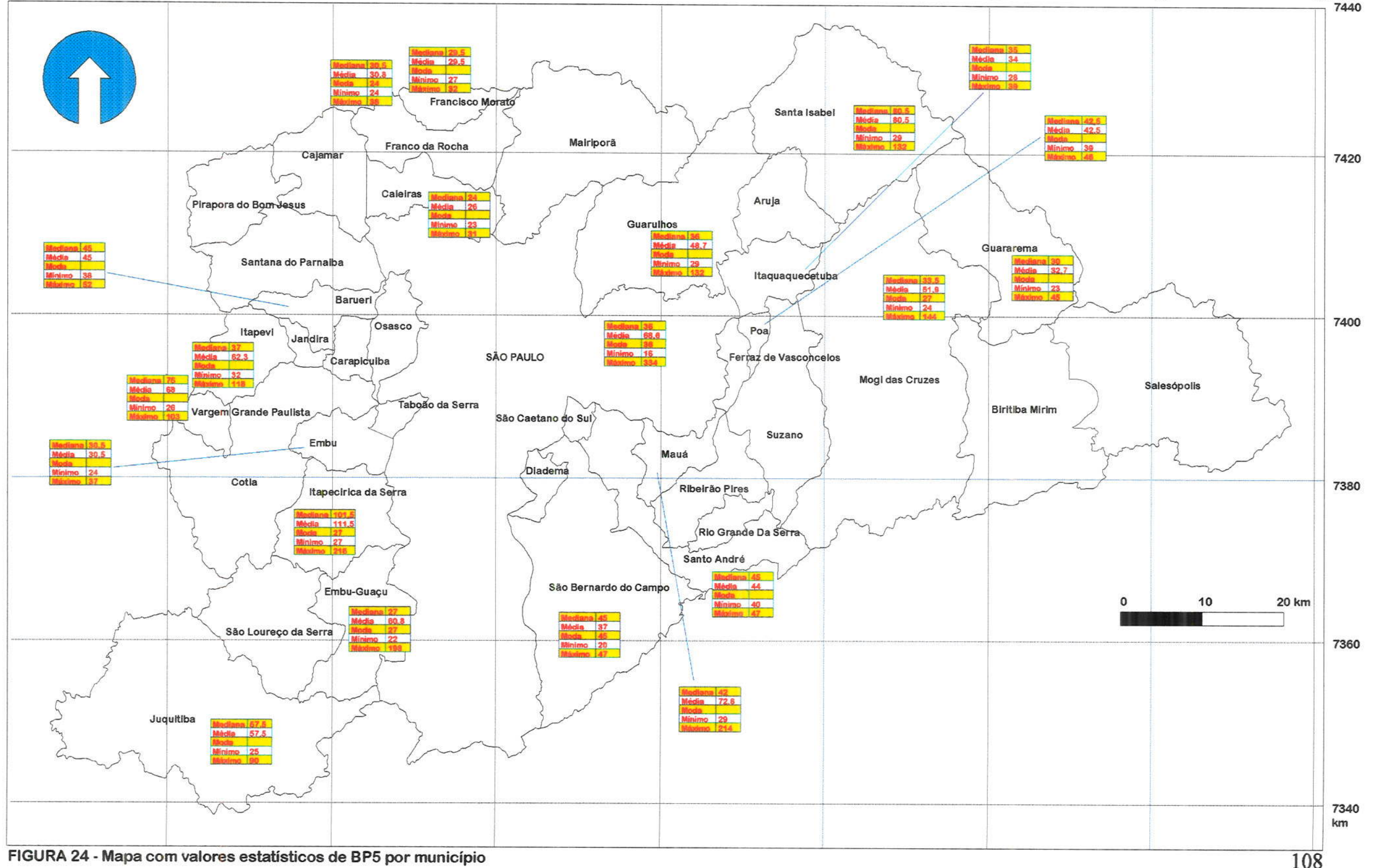







Assim, provavelmente as áreas de pontuação alta devem estar refletindo os locais onde existe o uso da água subterrânea nas proximidades do local de disposição, provavelmente através de cacimbas.

No BP3, uso do solo, os locais de pontuação mais alta estão situados principalmente junto aos municípios imediatamente adjacentes a São Paulo (FIGURAS 16 e 22). Os locais de disposição do município de São Paulo normalmente possuem boa obra de engenharia, seja na fase de operação, através de construções de drenos de gases e recobrimento diário dos resíduos, evitando-se o risco de migração de gases e/ou partículas nas edificações situadas nas proximidades do local. Nos municípios periféricos da RMSP, nas regiões sul, leste e norte, as edificações estão distantes dos locais de disposição, diminuindo o potencial de risco à saúde e vida destas populações. Por outro lado, nos municípos situados imediatamente adjacentes a São Paulo, as áreas de disposição situavam-se distantes das áreas de ocupação humana, mas por falta de oferta de espaço para ocupação humana, as áreas próximas aos locais de disposição foram ocupadas.

Em relação ao BP4, proteção das águas subterrâneas e superficiais, os valores de pontuação apresentados demonstram predominantemente números baixos (FIGURAS 17 e 23). Conforme analisado para o caso do BP2, os locais de disposição situam-se distantes dos principais reservatórios. Além disso, os locais que se situam nas proximidades dos reservatórios possuem coleta de lixiviados. No caso das águas subterrâneas, observa-se que 77 locais encontram-se no contexto das rochas cristalinas e o restante na bacia sedimentar. Os locais de deposição situados sobre o aqǘfero sedimentar estão, em sua maioria, em áreas de descarga de água subterrânea, minimizando os riscos.

No caso do bem a proteger BP5, uso agrícola e pecuária, a maioria das áreas apresentou pontuação bastante baixa (FIGURAS 18 e 24), existindo apenas alguns casos com pontuação média a alta na periferia de alguns municípos, ou ainda, em alguns municípios periféricos da RMSP. Este fato torna-se coerente quando se considera que na RMSP predominam atividades industriais e de serviços.

A pontuação relativa a outros bens a proteger, apresentada nas figuras 19 e 25 , indica que os valores médios a altos predominam sobre os baixos. Este fato ocorre porque os locais de disposição normalmente situam-se nas porções periféricas dos municípios, e nestes locais 
encontram-se preservados bens ambientais como matas naturais, além das APAs e APMs que compreendem municípios da RMSP.

\subsubsection{Classificação das áreas de disposição}

Os dados de pontuação obtidos e listados no Anexo 2, foram organizados em intervalos de valores, para cada bem a proteger, como apresentado no quadro 22 .

Quadro 22. Número de áreas de disposição por intervalo para os bens a proteger (BP1 a BP6)

\begin{tabular}{|c|c|c|c|c|c|c|}
\hline INTERVALO/BENS A PROTEGER & BP1 & BP2 & BP3 & BP4 & BP5 & BP6 \\
\hline $0-50$ & 21 & 72 & 79 & 68 & 88 & 12 \\
\hline $51-100$ & 27 & 12 & 18 & 13 & 9 & 20 \\
\hline $101-200$ & 34 & 17 & 8 & 20 & 7 & 39 \\
\hline $201-300$ & 19 & 5 & 3 & 4 & 3 & 16 \\
\hline $301-400$ & 6 & 2 & 1 & 3 & 2 & 13 \\
\hline $401-500$ & 1 & 0 & 0 & 0 & 0 & 6 \\
\hline $501-600$ & 1 & 1 & 0 & 0 & 0 & 1 \\
\hline $600-700$ & 1 & 0 & 0 & 1 & 0 & 1 \\
\hline
\end{tabular}

subterrâneas e superficiais; BP5 - Uso agrícola e pecuária; BP6 - Outros bens a proteger

Para os dados de pontuação obtidos para cada bem a proteger foi confeccionado um gráfico com valores de pontuação no eixo das abcissas e números de locais de disposição no eixo das ordenadas.

O bem a proteger BP1, saúde e vida da população, apresentou cerca de $44 \%$ dos casos entre os intervalos de 0 a 100 pontos, $49 \%$ entre 101 e 300 pontos e $7 \%$ acima de 301 pontos (FIGURA 26). Portanto, mais da metade dos locais de disposição apresenta valores médios a altos.

No caso do BP2, abastecimento público, aproximadamente $78 \%$ dos locais apresentam pontuação abaixo de 100 pontos. Entre os locais restantes, $20 \%$ apresentaram valores entre $101 \mathrm{e}$ 

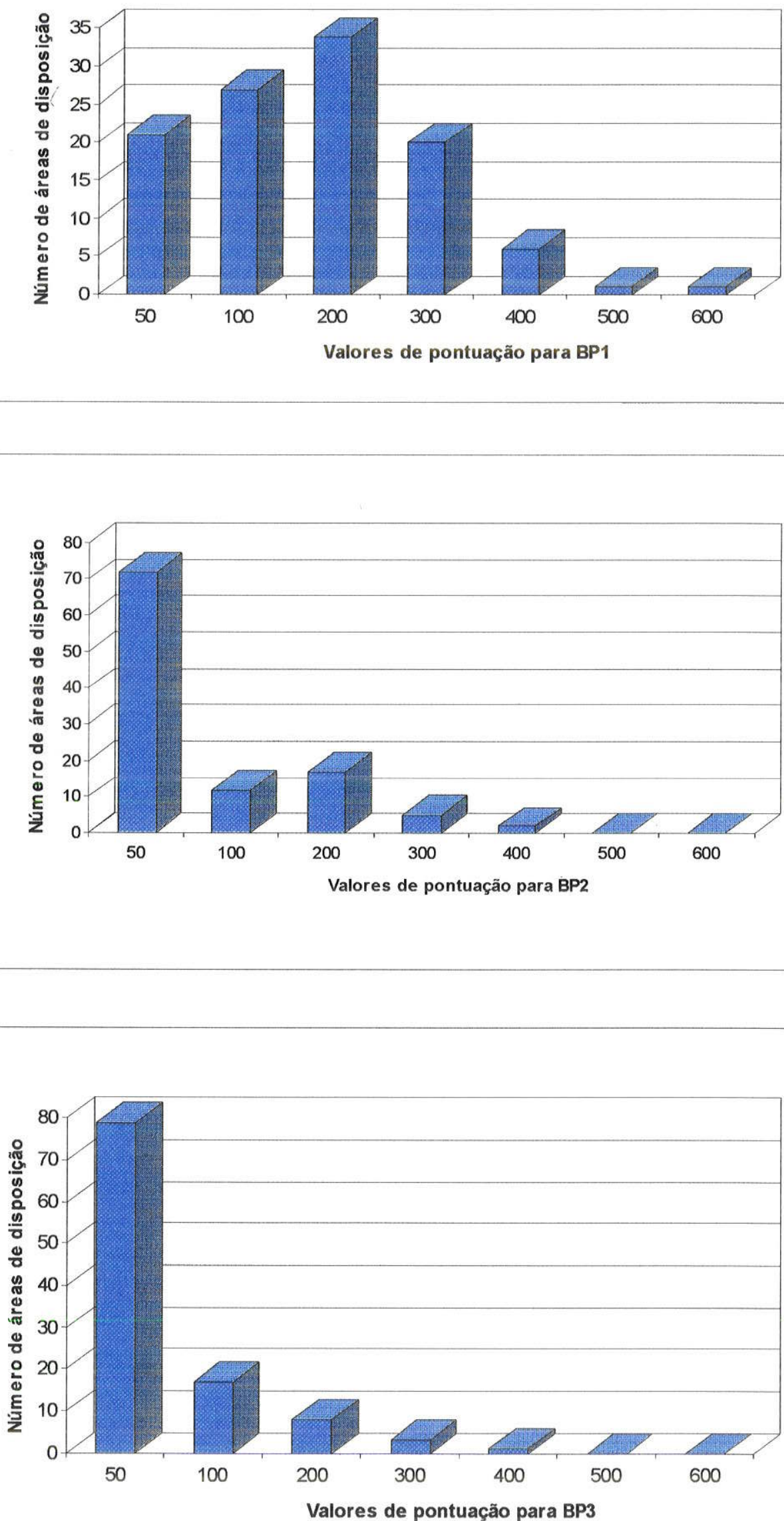

FIGURA 26 - Figura demonstrando a distribuição do número de áreas por faixa de pontuação para BP1, BP2, BP3 
300 e $2 \%$ situaram-se acima de 301 pontos (FIGURA 26). Assim, apenas $22 \%$ dos locais de disposição apresentaram valores médios a altos.

Para o BP3, uso do solo, aproximadamente $89 \%$ dos casos apresentaram pontuação abaixo de 100 pontos. Os $11 \%$ restantes, estão distribuídos respectivamente, $10 \%$ entre o intervalo de 101 a 300 pontos e $2 \%$ acima de 301 pontos (FIGURA 26). Dessa forma, somente $11 \%$ das áreas possuem valores médios a altos.

Para o BP4, proteção das águas subterrâneas e superficiais, cerca de $75 \%$ dos locais estão com valores abaixo de 100 pontos. Do restante, $22 \%$ e $3 \%$, estão respectivamente distribuídos nos intervalos de 101 a 300 pontos e acima de 301 pontos (FIGURA 27). Portanto, $25 \%$ dos casos possuem valores médio a altos.

O bem a proteger BP5, uso agrícola e pecuária, possui cerca de $89 \%$ dos casos com pontuação abaixo de 100 . Os $11 \%$ restantes estão distribuídos entre os valores de 101 a 400 pontos (Figura 27). Portanto, neste caso, os locais com valores médios a altos somam apenas $11 \%$.

No caso do BP6, outros bens a proteger, aproximadamente $30 \%$ dos casos encontram-se entre os valores de 0 a 100 pontos (Figura 27), 51\% entre o intevalo de 101 a 300 pontos e $19 \%$ acima de 300 pontos. Dessa forma, um total de $70 \%$ das áreas apresentaram valores médios a altos.

\subsubsection{Priorização das áreas de disposição}

Nos ítens anteriores foram realizados a classificação e a distribuição espacial dos locais de disposição da RMSP. Basicamente foram observadas, para os cinco bens a proteger, situações onde os locais de disposição apresentam valores de pontuação bastante altos. A avaliação foi realizada apenas para BP1 a BP5, excluindo-se o BP6, para considerar aqueles bens a proteger que atingem direta ou indiretamente a vida ou a saúde da população. Como o BP6 refere-se mais à preservação de recursos naturais, não foi considerado nesta avaliação final.

No presente trabalho considera-se como valor crítico (para os cinco bens a proteger) aqueles locais classificados com pontuação acima de 200. Este valor limite foi definido 



FIGURA 27 - Figura demonstrando a distribuição do número de áreas por faixa de pontuação para BP4, BP5, BP6 
associando-se os valores numéricos à situação real observada no campo. Nas tabelas 11 a 15 encontram-se listados 28 áreas críticas para o BP1, 8 para o BP2, 4 para o BP3, 8 para o BP4 e 5 para o BP5.

Entre as áreas consideradas como críticas, e apresentadas nas tabelas 11 a 15, existem alguns locais que apresentam pontuações elevadíssimas. Na Tabela 16 estão listadas 15 áreas que apresentaram pontuação acima de 300. Dentre elas o Lixão de Alvarenga destaca-se com pontuação acima de 600 , para BP1 a BP4.

\section{AVALIAÇÃO LOCAL: LIXÃO DO ALVARENGA}

O intuito básico de apresentar as informações do Lixão do Alvarenga é mostrar um caso específico de aplicação da metodologia de Gestão de Áreas Contaminadas em áreas de disposição de resíduos sólidos. A escolha deste lixão para o estudo de caso é decorrência de sua importância histórica em relação a disposição inadequada de resíduos sólidos na RMSP e também pela pontuação elevadíssima obtida para vários bens a proteger obtidos na etapa de avaliação preliminar.

O Lixão do Alvarenga é um exemplo clássico de deposição de resíduos com ausência de critérios construtivos, operacionais e de encerramento de área. Estas características, com certeza, prejudicaram a qualidade de vários bens, como água superficial, água subterrânea, solo, saúde pública, vegetação, conforme será demonstrado nos ítens seguintes.

\subsection{Localização}

A área do Lixão do Alvarenga situa-se exatamente no limite dos municípios de Diadema e São Bernardo do Campo. O acesso à área, a partir de São Paulo, é feito através da Rodovia Imigrantes (FIGURA 28). $\mathrm{Na}$ altura do $\mathrm{km} 20$ da rodovia toma-se um acesso secundário em direção ao Bairro da Paz e em seguida ao Bairro do Eldorado, onde localiza-se o lixão. 
Tabela 11. Areas criticas de disposiçăo de residuos para o BP1

\begin{tabular}{|c|c|c|c|}
\hline Num & Municipio & Denominação & Pontuação \\
\hline 1 & Arujá & Antigo Lixăo Municipal & 298 \\
\hline 2 & Barueri & Lixão Motel Bahamas & 234 \\
\hline 3 & Barueri & Lixão de Barueri & 203 \\
\hline 4 & Biritiba Mirim & Antigo Lixão da Estr. Sta Catarina & 304 \\
\hline 5 & Caieiras & Inibra & 216 \\
\hline 6 & Diadema & Lixăo do Alvarenga & 684 \\
\hline 7 & Franco da Rocha & Morro do Lixắ II & 237 \\
\hline 8 & Franco da Rocha & Lixão Municipal (Mimi) & 228 \\
\hline 9 & Francisco Morato & Antigo Lixão de Francisco Morato & 508 \\
\hline 10 & Guarulhos & Parque Ecológico do Tieté & 413 \\
\hline 11 & Itapecirica da Serra & Antigo Lixăo de Itapecirica 2 & 342 \\
\hline 12 & Itapecirica da Serra & Antigo Lixấo do Jd. São Marcos & 287 \\
\hline 13 & Itapevi & Lixăo Desativado & 276 \\
\hline 14 & Mauá & Lara/Sertăozinho & 307 \\
\hline 15 & Mogi das Cruzes & Lixăo Bairro Rodeio & 212 \\
\hline 16 & Mogi das Cruzes & Lixão Volta Fria III & 225 \\
\hline 17 & Poá & Lixão da Vila Varela & 282 \\
\hline 18 & Săo Bern. Campo & Lixão Tiro de Guerra & 375 \\
\hline 19 & São Paulo & Aterro Sanitário de Sapopemba & 204 \\
\hline 20 & Săo Paulo & Aterro Jacuí & 249 \\
\hline 21 & Sáo Paulo & Lixăo Sapopemba IV & 207 \\
\hline 22 & São Paulo & Lixão Sapopemba V & 203 \\
\hline 23 & Săo Paulo & Lixão Sapopemba VII & 287 \\
\hline 24 & Såo Paulo & Aterro Sanitário de Santo Amaro & 214 \\
\hline 25 & São Paulo & Aterro de Vila Curuça & 294 \\
\hline 26 & Salesópolis & Lixåo do Matadouro & 204 \\
\hline 27 & Varg. Gr. Paulista & Lixão da Rua Palestina & 307 \\
\hline 28 & Guarulhos & Lixăo Edson Batista & 303 \\
\hline
\end{tabular}


Tabela 12. Areas criticas de disposiçăo de resíduos para o BP2

\begin{tabular}{c|l|l|c}
\hline Num & \multicolumn{1}{|c|}{ Município } & \multicolumn{1}{|c}{ Denominaçăo } & Pontuaçăo \\
\hline 1 & Caieiras & Lixăo Municipal Caieiras & 213 \\
\hline 2 & Cajamar & Lixăo Municipal Cajamar & 301 \\
\hline 3 & Diadema & Lixăo do Alvarenga & 637 \\
\hline 4 & Guarulhos & Jardim Arapongas 2 & 225 \\
\hline 5 & Itapevi & Lixăo Desativado & 360 \\
\hline 6 & Itaquaquecetuba & Lixăo Terra Rocha & 250 \\
\hline 7 & Poá & Lixăo Água Vermelha & 230 \\
\hline 8 & Săo Paulo & Lixăo Sapopemba VII & 299 \\
\hline
\end{tabular}

Tabela 13. Áreas críticas de disposição de resíduos para o BP3

\begin{tabular}{c|l|l|c}
\hline Num & \multicolumn{1}{|c|}{ Município } & \multicolumn{1}{|c}{ Denominaçăo } & Pontuação \\
\hline 1 & Arujá & Antigo Lixăo Municipal & 392 \\
\hline 2 & Caieiras & Inibra & 241 \\
\hline 3 & Diadema & Lixăo do Alvarenga & 704 \\
\hline 4 & Itaquaquecetuba & Aterro CIPAS & 204 \\
\hline
\end{tabular}

Tabela 14. Áreas críticas de disposiçăo de resíduos para o BP4

\begin{tabular}{c|l|l|c}
\hline Num & \multicolumn{1}{|c|}{ Município } & \multicolumn{1}{|c|}{ Denominação } & Pontuação \\
\hline 1 & Caieiras & Lixão Municipal Caieiras & 223 \\
\hline 2 & Cajamar & Lixăo Municipal Cajamar & 301 \\
\hline 3 & Diadema & Lixăo do Alvarenga & 637 \\
\hline 4 & Itapevi & Lixão Desativado & 375 \\
\hline 5 & Mairiporã & Antigo Lixăo Municipal & 209 \\
\hline 6 & Poá & Lixăo Agua Vermelha & 230 \\
\hline 7 & Săo Paulo & Lixão Sapopemba VII & 312 \\
\hline 8 & Săo Paulo & Lixăo Vila Albertina & 201 \\
\hline
\end{tabular}


Tabela 15. Áreas críticas de disposiçăo de resíduos para o BP5

\begin{tabular}{c|l|l|c}
\hline Num & \multicolumn{1}{|c|}{ Município } & \multicolumn{1}{|c}{ Denominação } & Pontuaçăo \\
\hline 1 & Caieiras & Lixão Municipal Caieiras & 205 \\
\hline 2 & Embu Guaçu & Lixão Desat. Bairro do Paca & 334 \\
\hline 3 & Embu Guaçu & Lixão Beira da Estrada & 334 \\
\hline 4 & Mairiporă & Antigo Lixão Municipal & 214 \\
\hline 5 & Săo Paulo & Lixăo Jardim São Joăo & 216 \\
\hline
\end{tabular}

Tabela 16. Áreas críticas de disposição de resíduos para BP1 a BP6 (com pontuação acima de 300)

\begin{tabular}{l|l|c|c|c|c|c}
\hline \multicolumn{1}{c|}{ Municipio } & \multicolumn{1}{|c|}{ Denominaçăo } & BP1 & BP2 & BP3 & BP4 & BP5 \\
\hline Arujá & Ant Lixăo Muniçpal & & & 392 & & \\
\hline Bir Mirim & Ant Lix da Estr. Sta Cat & 304 & & & & \\
\hline Cajamar & Lix Mun de Cajamar & & 301 & & 301 & \\
\hline Diadema & Lix do Alvarenga & 684 & 637 & 704 & 637 & \\
\hline E Guaçu & Lix Desat. B. do Paca & & & & & 334 \\
\hline E Guaçu & Lix Beira da Estrada & & & & & 334 \\
\hline F Morato & Ant Lixăo Franc Mor & 508 & & & & \\
\hline Guarulhos & Lixáo Edson Batista & 303 & & & & \\
\hline Guaruthos & Parque Ec do Tietê & 413 & & & & \\
\hline Itap Serra & Ant Lixăo de Itapec 2 & 342 & & & & \\
\hline Itapevi & Lixăo Desativado & & 360 & & 301 & \\
\hline Mauá & Lara/Sertăozinho & 307 & & & & \\
\hline S. B. Cam & Lix Tiro de Guerra & 375 & & & & \\
\hline Săo Paulo & Lix Sapopemba VII & & & & 312 & \\
\hline V.Gr. Paul & Lix da Rua Palestina & 307 & & & & \\
\hline
\end{tabular}




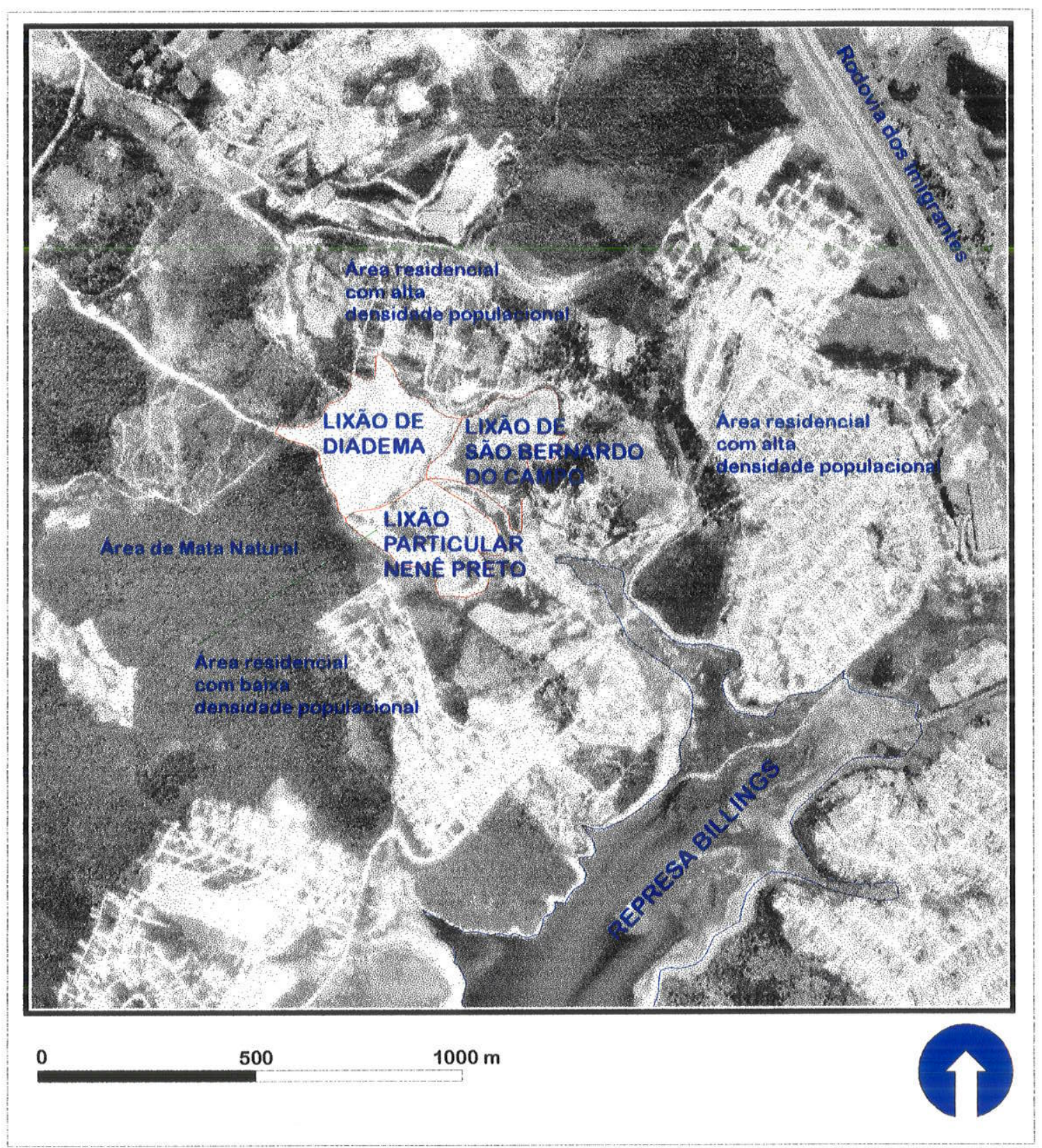

FIGURA 28 - Localização do Lixão de Alvarenga 


\subsection{Descrição da área do lixão e adjacências}

Até a década de 60, o Bairro do Eldorado onde está localizado o Lixão do Alvarenga, era considerado um local de lazer perfeito em função das belezas naturais, como a presença da mata atlântica e da represa Billings, com água de excelente qualidade. A denominação Eldorado tem origem nas características acima apresentadas associada ao clima ameno e bastante agradável da região, até muitas vezes comparado ao clima europeu.

Entretanto, com o crescimento econômico e industrial da região do $\mathrm{ABC}$ nestas últimas quatro décadas, o bairro recebeu uma ocupação desordenada inclusive com a instalação do Lixão do Alvarenga.

Assim, o Bairro Eldorado caracteriza-se hoje pela ocupação por população de baixa renda, que na maioria dos casos, reside em barracos e possui apenas parte dos serviços públicos de infraestrutura instalados. $O$ bairro não possui pavimentação asfáltica e muito menos coleta de esgoto. Em Eldorado ainda existem áreas remanescentes da mata atlântica e o bairro encontra-se adjacente à represa Billings.

\subsection{Avaliação Preliminar}

Neste ítem serão inicialmente descritas as informações obtidas a partir da Ficha Cadastral da área do Lixão do Alvarenga, informações estas que também foram aplicadas na Ficha de Pontuação (ANEXO 1).

\subsubsection{Diagnóstico da área de disposição}

As informações apresentadas neste ítem encontram-se sintetizadas na Ficha Cadastral que foi preenchida em vistoria realizada ao local em junho de 1994

O Lixão do Alvarenga é constituído pelo Lixão de Diadema, Lixão de São Bernardo e Lixão Particular do Nene Preto (FIGURA 28). Estas três áreas de deposição juntas somam cerca 
de $350.000 \mathrm{~m}^{2}$ e a espessura de lixo depositado varia de alguns metros até 50 metros. Para uma melhor visualização da área, na Figura 29 são apresentadas ilustrações fotográficas dos três lixões.

Geologicamente, o local de deposição situa-se na área de ocorrência de micaxistos. Esta rocha encontra-se bastante intemperizada e não são comuns afloramentos nas proximidade do Lixão do Alvarenga.

Quanto à morfologia da área, em função de sua grande extensão, o local de deposição ocupa desde regiões de topo até zonas de encosta e de várzeas nas proximidades da Represa Billings. Assim, a associação entre as condições de relevo pretéritas e a espessura de massa de resíduo atual devem ter imposto novas condições de fluxo ao lençol freático local, possivelmente transferindo lixiviados diretamente para a água subterrânea.

A disposição de resíduos sólidos no Lixão do Alvarenga teve início em 1974 e atualmente recebe apenas entulhos, restos de madeiras e aparas e outros materiais inertes.

No período em que a deposição era intensa, o local recebeu desde resíduos domésticos, até hospitalares e industriais, caracterizando-se como local sem controle de entrada de resíduos (FIGURA 30). Dessa forma, levando em consideração os tipos de resíduos depositados, podemse estimar que no local existam pelo menos compostos inorgânicos de elevada toxicidade, metais e compostos metálicos, derivados de petróleo e solventes orgânicos.

No aspecto construtivo, o lixão não dispõe de impermeabilização inferior e superior, tampouco drenagens de chorume e de águas superficiais. Assim, todo o chorume gerado no local tem como destino final a Represa Billings e a água subterrânea.

Por outro lado, em relação às drenagens de gases, o Lixão de Diadema possue 13 drenos de gases que continuam ativos até o momento. Nos outros dois lixões não existem drenos, e como consequência, há registro de explosão de gases na área do Lixão de São Bernardo no passado.

Quando os Lixões encontravam-se em franca atividade, existiam cerca de 300 catadores que sobreviviam dos materiais comercializáveis retirados dos locais de deposição. Atualmente, apenas algumas dezenas de catadores encontram-se em atividade principalmente no Lixão de Diadema (FIGURA 31).

Além dos catadores, tanto no passado como atualmente, existe circulação de animais na área dos lixões que se alimentam dos resíduos ou vegetação existente na área e/ou adjacências 

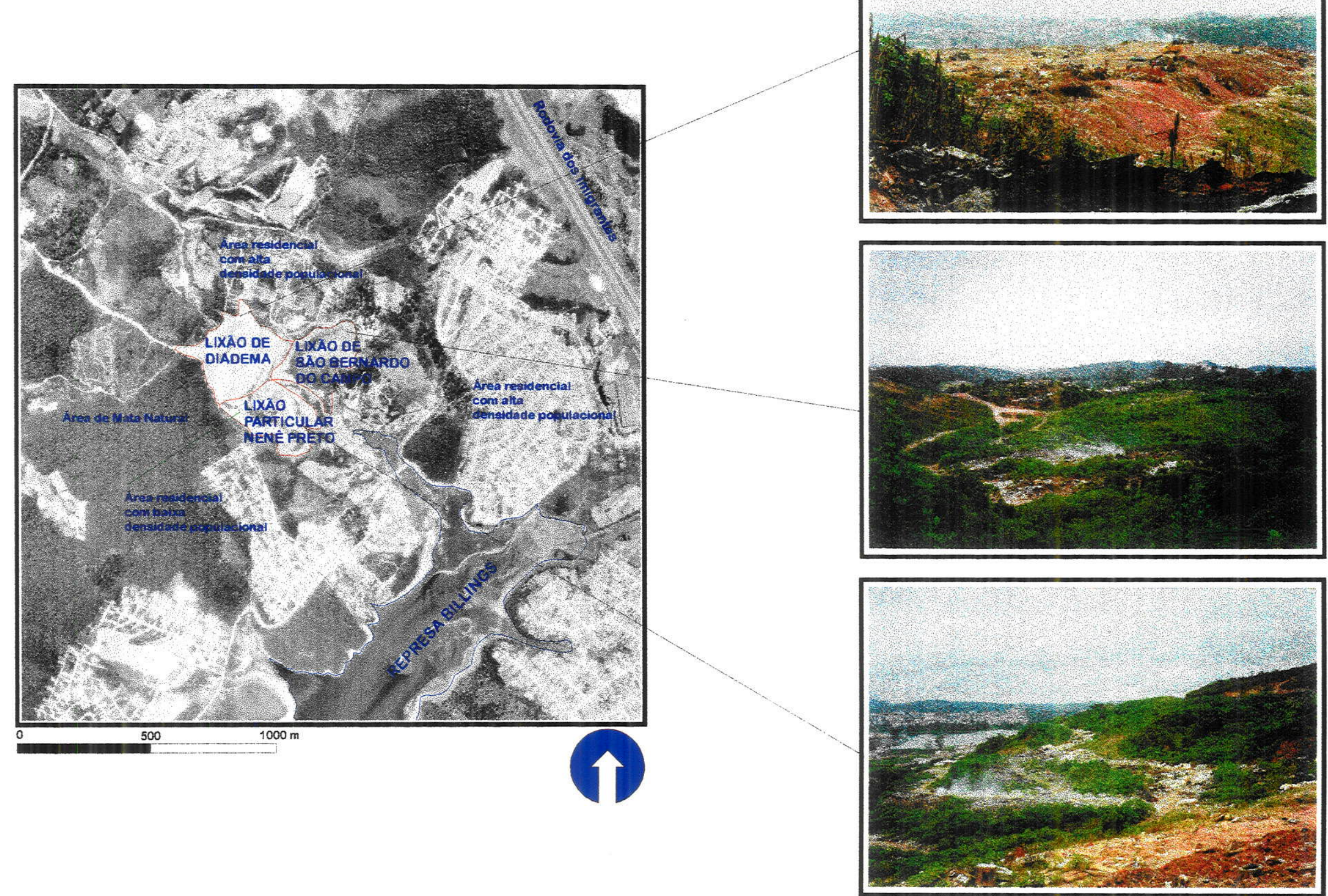

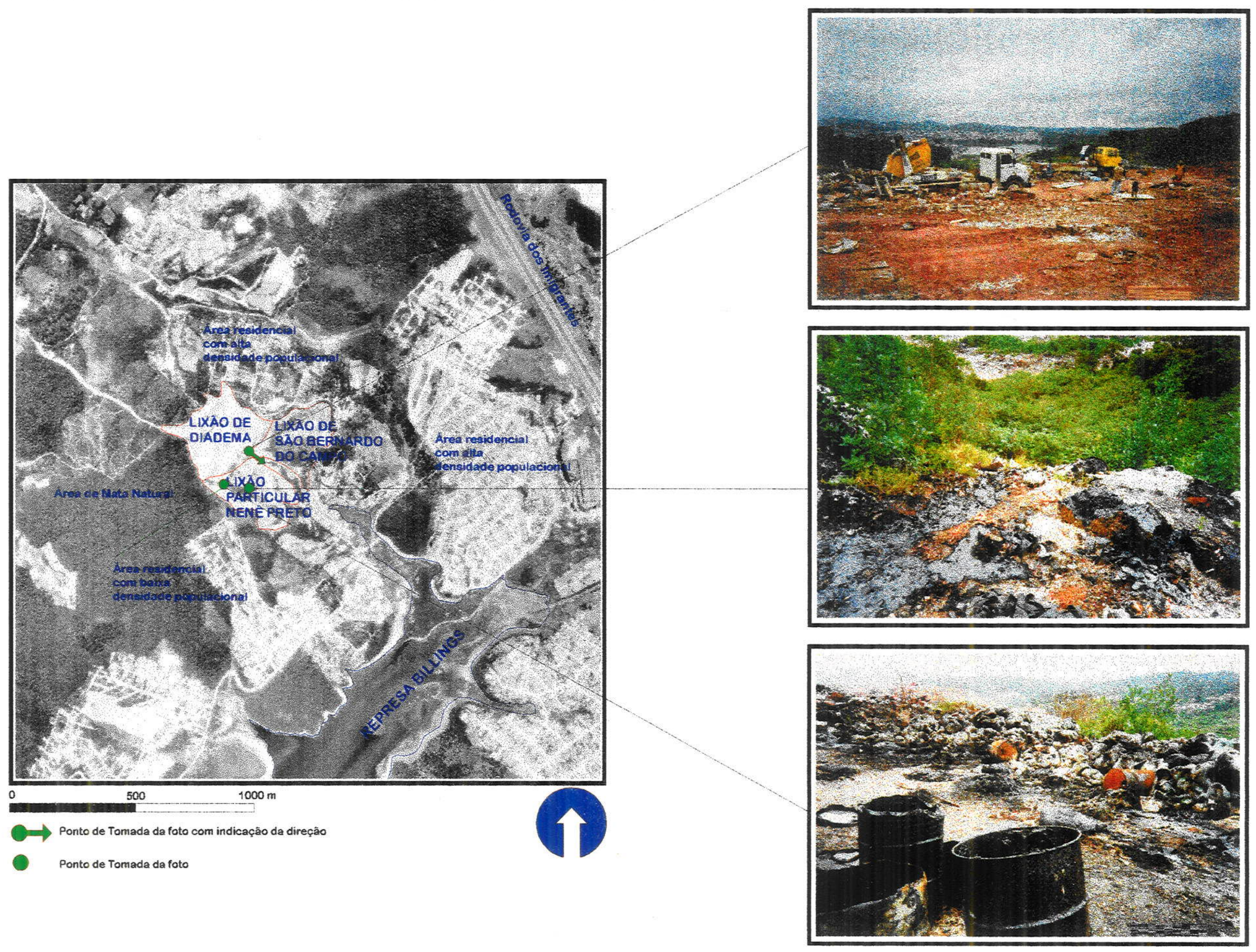


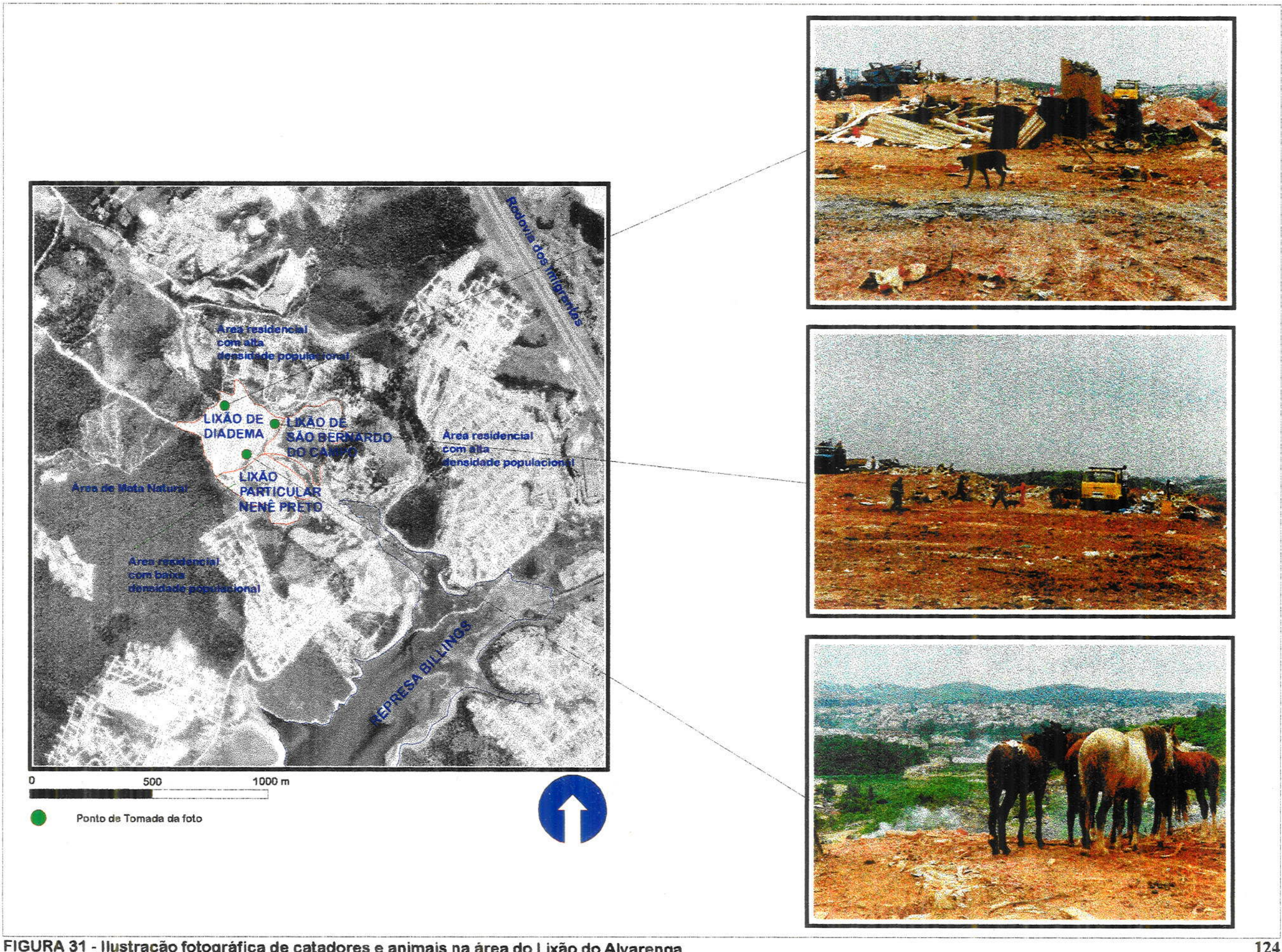


(FIGURA 31). Alguns deles apresentando doenças visíveis na pele, conforme constatado pela equipe de toxicologia da CETESB.

Nas adjacências do local de deposição, nas porções norte, leste e sul, existe ocupação por edificações e barracos de população de baixa renda (FIGURAS 28 e 29). Na porção sul existem casos onde os barracos encontram-se construídos sobre a massa de resíduo. Toda a face oeste da área dos lixões limita-se com a área remanescente da mata atlântica.

Ademais, cabe notar que no vale que se estende a partir do lixão em direção NW existe um dos pequenos braços da Represa Billings, para onde é escoado superficialmente uma boa parte do chorume gerado no Lixão do Alvarenga (FIGURA 32).

No aspecto da água subterrânea, observou-se que existem dezenas de residências que se utilizam da água do lençol freático, através de cacimbas, a jusante do local de deposição.

\subsubsection{Preenchimento da Ficha de Pontuação}

O preenchimento da Ficha de Pontuação para o Lixão do Alvarenga foi realizado com base nas informações obtidas através da Ficha Cadastral (ANEXO 1)

Conforme apresentado no ítem 6.2, o aspecto metodológico da avalição preliminar, o preenchimento da Ficha de Pontuação compreende três etapas básicas: características da fonte de contaminação, meios de propagação e os bens a proteger.

A seguir são descritas e discutidas as informações originárias da Ficha Cadastral do Lixão do Alvarenga que foram consideradas como relevantes para o preenchimento da Ficha de Pontuação.

\subsubsection{Características da fonte de contaminação}

$\mathrm{Na}$ ficha cadastral, a fonte de contaminação é caracterizada por meio de três tipos de 

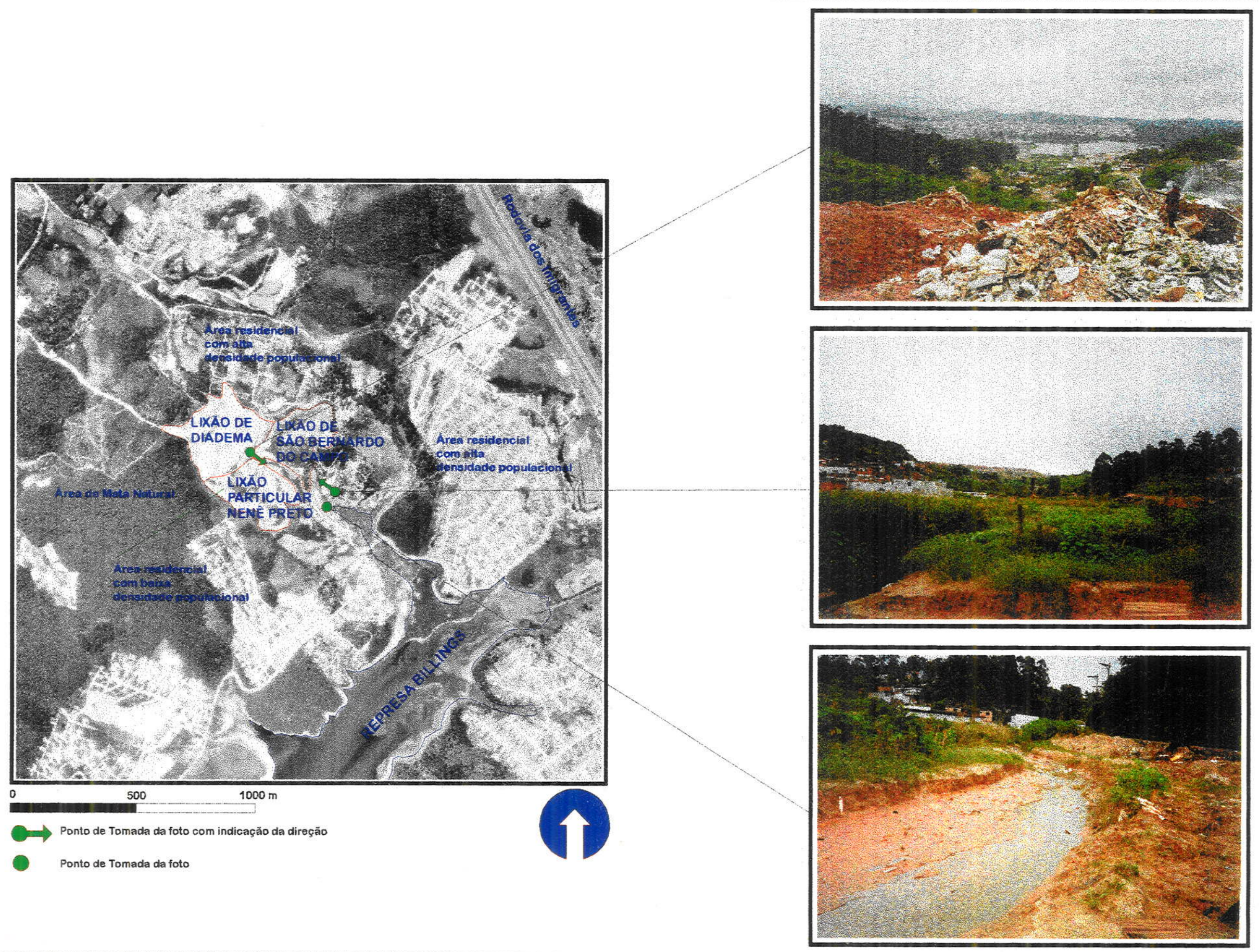
informações: tipo de resíduos, volume de resíduos e grupos de substâncias encontradas no resíduo (ANEXO 1).

Os tipos de resíduos encontrados no Lixão do Alvarenga foram: industrial, serviço de saúde, domiciliar, inerte, varrição e entulhos. Entre estes tipos de resíduos, os que tem origem na indústria e nos locais que prestam serviço à saúde pública são considerados de maior toxicidade.

O volume estimado de resíduos na área do Lixão do Alvarenga é da ordem de 5.250 .000 $\mathrm{m}^{3}$. Este volume foi obtido considerando-se que a área do lixão possue $350.000 \mathrm{~m}^{2}$ com espessura média de resíduo de $25 \mathrm{~m}$. Dessa forma, o dado de volume de resíduo indica que o lixão possue dimensões acima da média quando comparado aos outros locais de disposição da RMSP.

No aspecto dos grupos de substâncias possíveis de serem encontradas no lixão em estudo, ressalta-se que, na maioria dos casos, os parâmetros foram estimados em função dos tipos de resíduos observados no local. Assim, considerou-se a existência dos seguintes compostos: orgânicos halogenados voláteis, orgânicos não halogenados voláteis, hidrocarbonetos clorados voláteis, orgânicos nitrogenados, derivados de petróleo, metais e inorgânicos. Dos, compostos mencionados, os orgânicos e metais apresentam maior toxicidade à saúde humana.

A somatória destes três tipos de informações permitiu realizar a pontuação do potencial de risco da fonte de contaminação em relação aos seis bens a proteger (BP1 a BP6), conforme apresentado no Anexo 1.

\subsubsection{Meios de propagação}

Os meios de propagação são avaliados em quatro caminhos preferenciais de potenciais de transporte no sistema de pontuação: solo, água superficial, água subterrânea e ar.

- Solo

Para a avaliação da propagação dos possíveis contaminantes através do solo, inicialmente é considerado se existe a análise do solo em duas profundidades, 0 a 1 metro e maior que 1 metro. 
No caso do Lixão do Alvarenga não existe análise do solo realizada (ANEXO 1). Em seguida é avaliado se houve algum evento importante relacionado com o solo do lixão. Em Alvarenga foi observada erosão, dispersão de poeiras e desabamento de resíduos que podem facilitar o transporte de contaminantes através do solo. Também foi observado que os catadores, vegetação e algumas edificações que existem no local sofreram efeitos prejudiciais em função dos eventos acima.

Em decorrência da falta de impermeabilização superficial, existe problema de odor forte no local e, observa-se constantemente a presença de contaminantes na superficie do solo.

\section{- Água superficial}

Quanto à propagação dos contaminantes via água superficial é avaliada inicialmente a qualidade da água (superficial), e em seguida a possibilidade de haver a influência direta do contaminante nas águas superficiais, por exemplo escoamento do lixiviado para o corpo de água superficial. Por fim, considera-se a possibilidade de ocorrência de inundações ocasionando o contato direto do resíduo com a água superficial (ANEXO 1). A estes três níveis de avaliações é associada ainda a questão do uso da água superficial.

$\mathrm{Na}$ área do Lixão do Alvarenga, o chorume é carreado diretamente para a Represa Billings, mas não existe a possibilidade da água proveniente de enchentes atingir o resíduo. $\mathrm{Na}$ questão do uso da água, a represa é utilizada para abastecimento público, recreação e piscicultura.

\section{- Água subterrânea}

A propagação da água subterrânea é avaliada considerando-se sete fatores como de importância (ANEXO 1). Inicialmente é avaliado se existe a contaminação da água subterrânea comprovada por análise química. Em seguida é avaliado se existe o uso da água subterrânea afetada pela contaminação. No caso de Alvarenga, na época da visita ao campo, não existiam 
resultados de análise química comprovando a contaminação. Entretanto, cerca de uma dezena de residências possuiam cacimbas para a captação da água subterrânea localizada à jusante do lixão.

Outro aspecto avaliado é a questão da textura do solo local. A textura do solo está diretamente associada com a da permeabilidade, que de maneira simplificada, reflete a facilidade ou dificuldade do contaminante atingir a água subterrânea. No caso em questão predomina o solo siltoso.

A impermeabilização inferior é avaliada porque a sua inexistência significa que o resíduo está em contato direto com o solo, facilitando a transferência do contaminante para o solo e/ou água subterrânea. Em Alvarenga não existe nenhum tipo de impermeabilização inferior. Como consequência, um dos destino finais dos líquidos percolados seguramente é o solo, e por final, a água subterrânea.

Outro fator importante é a profundidade do nível do lençol freático. No Lixão do Alvarenga o resíduo está em contato direto com a água subterrânea, principalmente nos pontos situados nas várzeas. $\mathrm{O}$ contexto hidrogeológico em que está inserido o lixão pode ser descrito como área de ocorrência do aquífero cristalino com manto de material de textura siltosa. Devido a grande dimensão da área de disposição, o lixão ocupa tanto área de recarga como de descarga local.

- $\operatorname{Ar}$

A propagação via ar refere-se especificamente à possibilidade dos gases gerados no local de deposição migrarem e atingirem os bens materiais e a saúde da população (ANEXO 1). Assim sendo, a avaliação inicial procura verificar se a zona não-saturada encontra-se contaminada através da realização de análise química. No caso de Alvarenga não existe análise química dos gases gerados no local.

Numa etapa posterior é avaliada a questão de eventos importantes no local do lixão. No Lixão do Alvarenga existem registros de explosões no passado, e atualmente ainda é possível observar a presença de gases no local, gases estes que não são coletados através de drenos. Apenas o Lixão pertencente ao município de Diadema possue drenos de gases. 
Por final, avalia-se a distância das edificações nas proximidades do local de disposição e se há presença de gases nelas. Em Alvarenga as edificações situam-se a menos de 50 metros e atualmente não se observa a presença de gases nas residências.

\subsubsection{Bens a Proteger}

A avaliação dos bens a proteger foi feita levando em consideração os bens que se encontram na área e aqueles situados nas adjacências (ANEXO 1). Os bens registrados na área de disposição foram: áreas residênciais com baixa densidade populacional, área verde e de mata natural, Área de Proteção Ambiental, Área de Proteção de Mananciais, aquífero cristalino e poços de abastecimento domiciliar.

Nas adjacências do local de disposição existem áreas residenciais com alta densidade populacional, Área de Proteção Ambiental, Área de Proteção de Mananciais, bacia hidrográfica de abastecimento público, aquífero cristalino e poços de abastecimento domiciliar.

\subsubsection{Resultado da Pontuação}

O resultado da pontuação obtida para o Lixão de Alvarenga, apresentada no Anexo 1 e tabela 17, mostra-se bastante coerente para os seis bens a proteger considerados. Apenas o bem a proteger BP5 apresentou-se com pontuação baixa uma vez que não existe atividade agrícola e/ou pecuária na área ou adjacências do Lixão do Alvarenga.

Tabela 17. Pontuação Lixão de Alvarenga

\begin{tabular}{|l|c|}
\hline \multicolumn{1}{|c|}{ BENS A PROTEGER } & PONTOS \\
\hline Saúde e vida da população (BP1) & 684 \\
\hline Abastecimento público (BP2) & 637 \\
\hline Uso do solo (BP3) & 704 \\
\hline Proteção das águas subterrâneas e superficiais (BP4) & 637 \\
\hline Uso agrícola e pecuária (BP5) & 58 \\
\hline Outros bens a proteger (BP6) & 646 \\
\hline
\end{tabular}


Assim, na questão da saúde e vida da população (BP1), conforme descrito anteriormente, existem vários aspectos preocupantes. Os catadores presentes na área apresentam doenças visíveis de pele conforme constatado pela equipe de toxicologia da CETESB. As residências localizadas na área e nas adjacências correm sérios riscos de sofrer acidentes, seja por explosões dos gases seja pelo desabamento do lixão.

A Represa Billings é uma fonte de abastecimento público (BP2) de água para a RMSP. O chorume gerado no lixão é escoado diretamente para a represa.

O conflito do uso do solo (BP3) ocorre tanto no aspecto social como no de saúde pública para a população residente na área e adjacências do lixão. Eles convivem diretamente com o problema de doenças de veiculação hídrica, mau cheiro, escoamento de chorume e grande quantidade de insetos e roedores.

Na questão da proteção das águas subterrâneas e superficiais (BP4), o caso da contaminação das águas superficiais parece ser mais grave, uma vez que a água subterrânea tem apenas importância local. A água da Represa billings é utilizada por milhares de pessoas da RMSP.

Por final, no aspecto outros bens a proteger destaca-se a inserção do lixão na Área de Proteção Ambiental contribuindo para a degradação das matas naturais.

\subsection{Avaliação Confirmatória}

Conforme descrito no ítem 6.3 , a avaliação confirmatória em áreas de disposição de resíduos sólidos deve investigar a possível presença de contaminantes nos meios solo, água superficial, água subterrânea e ar. $\mathrm{Na}$ área do Lixão do Alvarenga não existe investigação realizada nestes quatro meios.

Entretanto, DEHAINI (1995) trabalhou na área do lixão realizando a aplicação de métodos geofísicos que servem de subsídio para a avaliação confirmatória. Confrontando-se os resultados geofísicos com a avaliação preliminar, apresentada no ítem 7.3, pretende-se comprovar a eficiência da metodologia aplicada na área de Alvarenga, somente no aspecto das águas subterrâneas. 


\subsubsection{Levantamento Geofisico}

$\mathrm{Na}$ área de Alvarenga, DEHAINI (1995) realizou um total de 2860 metros de caminhamento eletromagnético, distribuídos em 7 perfis, com distância entre bobinas de 10 e 20 metros e o eixo das bobinas nas posições vertical e horizontal.

São aqui apresentados apenas os dados do levantamento realizado para a distância entre as bobinas de 10 metros com o eixo na posição horizontal, tendo em vista que esta configuração do equipamento geofísico foi a que apresentou resultados de melhor qualidade.

A figura 33 mostra o mapa de isovalores de condutividade elétrica para o levantamento realizado. No mapa, todos os valores acima de $5 \mathrm{mmho} / \mathrm{m}$ foram considerados anômalos, acima dos valores de "background". No mapa, denota-se a existência de 3 regiões com anomalia acentuada. Duas delas situam-se ao longo da drenagem que tem origem no Lixão de Diadema e encerra na Represa Billings. Outro situa-se na encosta onde está instalado o Lixão de São Bernardo do Campo.

\subsubsection{Resultados das análises químicas das cacimbas}

$\mathrm{Na}$ mesma área em que foi realizado o levantamento geofísico existem 16 cacimbas perfuradas pela população residente no local. DEHAINI (1995), coletou amostras de água para realizar análises químicas para os seguintes parâmetros: sódio, potássio, cálcio, magnésio, ferro, zinco e cobre. Além desses parâmetros, a autora analisou coliformes totais e fecais (TABELA 18).

Tabela 18. Características químicas e bacteriológicas das cacimbas em Alvarenga

\begin{tabular}{|l|r|r|r|r|r|r|r|c|c|}
\hline & \multicolumn{1}{|c|}{$\mathrm{Na}^{*}$} & \multicolumn{1}{|c|}{$\mathrm{Ca}^{*}$} & $\mathrm{Mg}^{*}$ & $\mathrm{Fe}^{*}$ & $\mathrm{Zn}^{*}$ & $\mathrm{Cu}^{*}$ & Col. Totais** & Col. Fecais** \\
\hline P06 & 3,8 & 0,8 & 2,0 & 0,2 & 0,04 & 0,05 & 0,03 & $3,0 \cdot 10^{3}$ & $3,0 \cdot 10^{2}$ \\
\cline { 2 - 10 } P10 & 24,0 & 5,4 & 9,1 & 2,9 & 0,04 & 0,13 & 0,07 & $3,0 \cdot 10^{2}$ & $3,0 \cdot 10^{2}$ \\
P18 & 6,6 & 1,9 & 9,1 & 2,1 & 0,03 & 0,08 & 0,03 & $1,3 \cdot 10^{4}$ & $8,0 \cdot 10^{2}$ \\
P21 & - & - & - & - & - & - & - & $1,7 \cdot 10^{3}$ & $5,0 \cdot 10^{1}$ \\
P22 & 5,1 & 0,9 & 0,5 & 0,8 & 0,05 & 0,05 & 0,03 & - & - \\
\cline { 2 - 10 } P23 & 167,5 & 45,0 & 4,8 & 5,0 & 0,08 & 0,07 & 0,03 & $4,0 \cdot 10^{1}$ & $4,0 \cdot 10^{1}$ \\
P27 & 11,0 & 0,8 & 4,1 & 0,5 & 0,72 & 0,06 & 0,03 & $1,6 \cdot 10^{4}$ & $9,0 \cdot 10^{1}$ \\
\cline { 2 - 9 } P29 & 10,2 & 1,5 & 5,8 & 2,5 & 0,07 & 0,05 & 0,03 & $1,4 \cdot 10^{3}$ & $7,0 \cdot 10^{1}$ \\
\cline { 2 - 9 } P36 & 1,5 & 1,3 & 1,2 & 0,6 & 0,25 & 0,05 & 0,03 & - & - \\
\cline { 2 - 9 } P45 & 2,5 & 0,3 & 0,3 & 0,1 & 0,19 & 0,05 & 0,03 & - & - \\
\cline { 2 - 8 } P47 & 13,0 & 16,5 & 25,8 & 5,0 & 3,54 & 0,05 & 0,03 & $8,0 \cdot 10^{1}$ & $8,0 \cdot 10^{1}$ \\
\hline
\end{tabular}

$\left(^{*}\right)$ Dados químicos em $\mathrm{mg} / \mathrm{l} ;\left(^{* *}\right)$ dados obtidos a partir da contagem para cada $100 \mathrm{ml}$ de água 


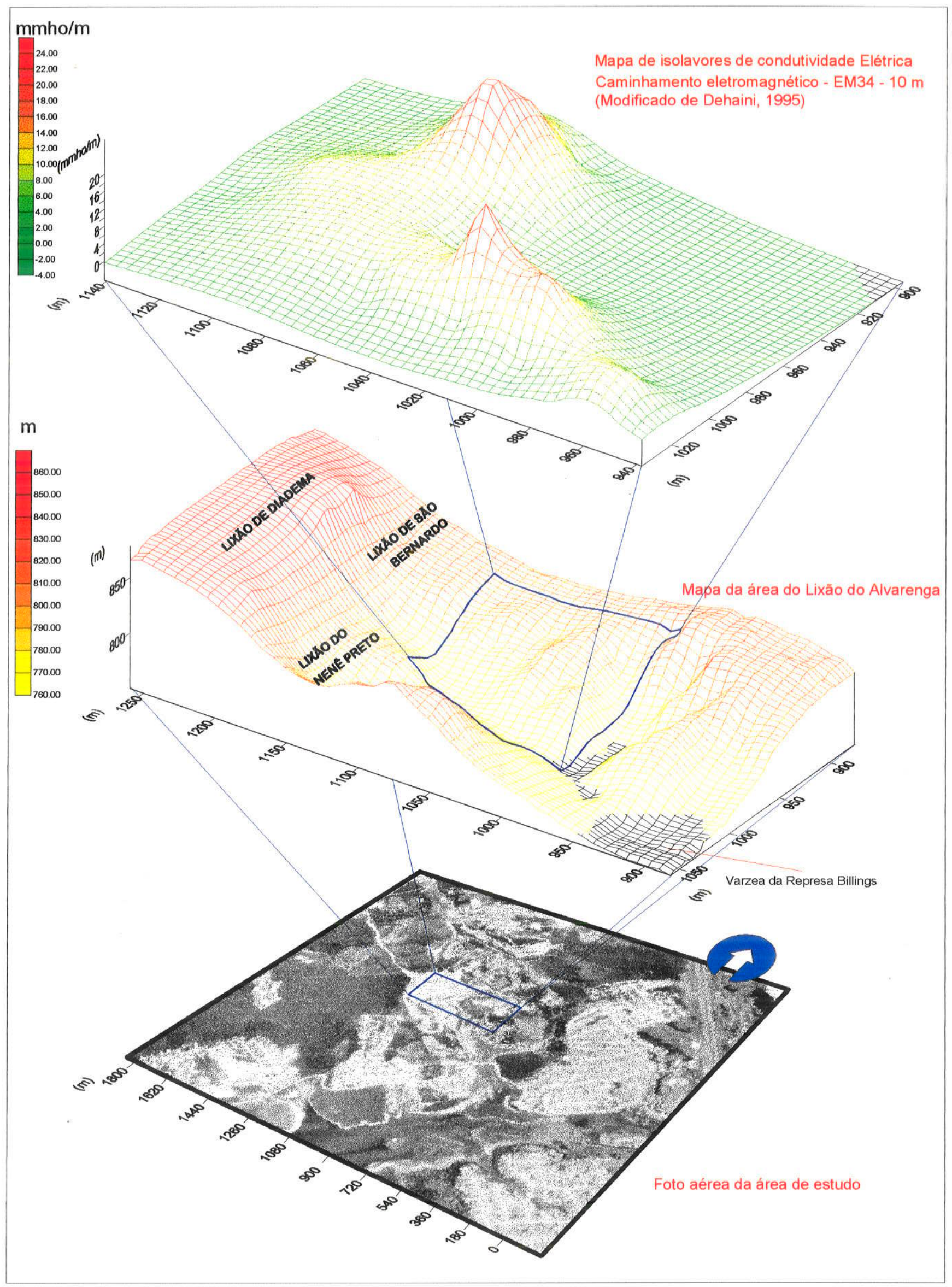

FIGURA 33 - Mapa de isovalores de condutividade elétrica na área do Lixão do Alvarenga 
Como pode ser observado nos dados da tabela 18, o sódio apresenta-se com concentração mais alta que outros elementos químicos. Utilizando-se os dados de concentração de sódio dos poços listados na tabela elaborou-se o mapa de isoconcentração, como mostra a figura 34.

Nesta figura, observa-se que existem duas áreas com concentrações elevadas de sódio, e que são coincidentes com aquelas áreas onde ocorrem valores de condutividade elétrica elevada, determinadas pelos métodos geofísicos, conforme mencionadas no ítem anterior. Somente a anomalia geofísica localizada mais próxima à Represa Billings não foi confirmada porque não existe cacimba na localidade.

A presença de coliformes totais e fecais indicam que as águas das cacimbas não apresentam condições sanitárias adequadas. Os coliformes podem ter origem tanto no lixão como no escoamento da água superficial. Portanto, os coliformes não são adequados para confirmar a contaminação da água subterrânea através do lixão.

\section{CONSIDERAÇÕES FINAIS}

$\mathrm{Na}$ primeira parte do presente trabalho foram apresentadas as várias metodologias de gestão de áreas contaminadas. Dentre estas, a metodologia Alemã foi selecionada para aplicação na RMSP porque houve o financiamento do projeto pela Gesellschaft Für Technische Zusammenarbeit (GTZ). Além disso a metodologia demonstrou-se adequada para ser aplicada na RMSP.

Entretanto, em função das várias características intrínsecas do país, abrangendo diferenças em questões culturais, problemas tecnológicos e aspectos climáticos, a metodologia escolhida foi submetida a adaptações, conforme apresentado na Parte 1.

Entre as adaptações observa-se que a Ficha Cadstral apresenta-se como um instrumento de coleta de informações bastante eficaz e rápido de ser manuseado no campo. Ela permite obter as informações do local de disposição como também das áreas adjacentes.

Uma das intenções iniciais do trabalho, era de que a Ficha Cadastral fosse facilmente preenchida por um técnico de nível médio. Mas a realidade da ficha elaborada demonstra que quando considerada a aplicação posterior ao preenchimento da ficha, é necessário que o técnico 


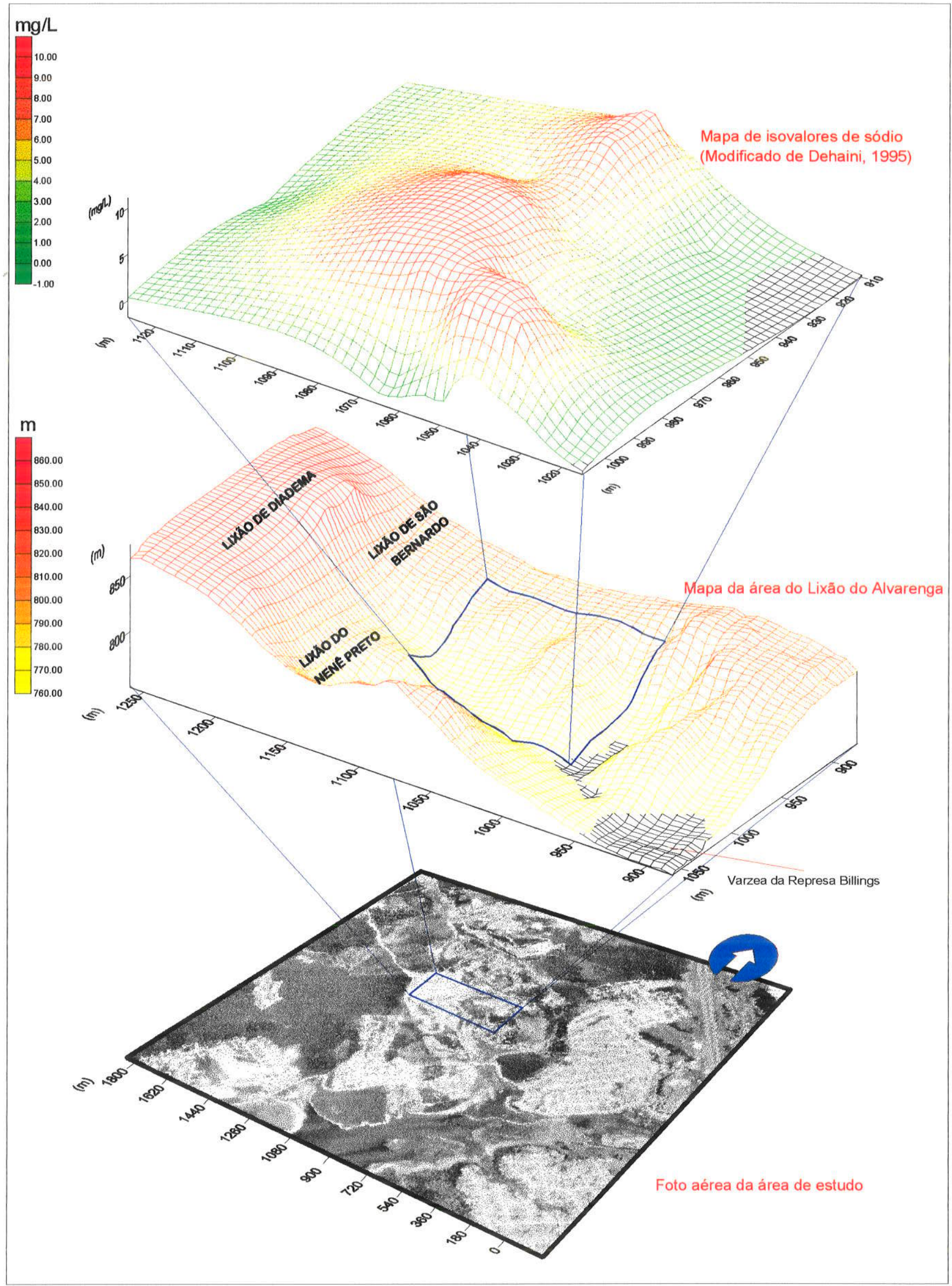

FIGURA 34 - Mapa de isoconcentração de sódio das águas subterrâneas provenientes das cacimbas na área do Lixão de Alvarenga 
receba treinamento para obter conhecimento sobre áreas contaminadas e resíduos sólidos, noções básicas sobre hidrogeologia, química, toxicologia e biologia.

As informações utilizadas para o preenchimento da Ficha de Pontuação são correspondentes àquelas obtidas através da Ficha Cadastral. Assim, as duas fichas em conjunto funcionam de uma forma eficaz para uma primeira classificação e priorização de áreas de disposição de resíduos sólidos na etapa de Avaliação Preliminar.

O tipo de metodologia de avaliação proposto, com base em dados existentes, demonstrase como de grande aplicabilidade num país como o Brasil, em função de seu baixo custo. A metodologia apresenta algumas deficiências por generalizar vários parâmetros do meio físico mas, por outro lado, quando for considerado o alcance em função dos investimentos financeiros, ela demonstra-se como um bom instrumento de trabalho.

Como resultado da aplicação das fichas foram priorizadas as áreas que atingiram pontuação acima de 200, conforme segue: 28 áreas críticas para saúde e vida da população (BP1), 8 para abastecimento público (BP2), 4 para uso do solo (BP3), 8 para proteção das águas subterrâneas (BP4) e 5 para uso agrícola e pecuária (BP5).

Não obstante a metodologia ter sido aplicada apenas para fins de avaliação confirmatória, e ainda que de uma forma parcial, com os resultados obtidos é possível delinear claramente algumas ações que podem ser tomadas imediatamente.

Na pontuação realizada para a RMSP ficou demonstrado claramente que a questão do risco da saúde e vida da população atinge níveis altíssimos principalmente para aqueles que vivem da renda (catadores) do local de disposição.

Entre as áreas priorizadas, o Lixão de Alvarenga apresentou a pontuação mais elevada na RMSP, para BP1 (684), BP2 (637), BP3 (704), BP4 (637) e BP6 (646). Esta pontuação elevada para a maioria dos bens a proteger conduziu a uma investigação mais detalhada do local conforme apresentado no ítem 6. Nesse ítem, além das características da área, mostrou-se também a aplicação de forma mais detalhada da Ficha Cadastral e de Pontuação.

Através dos dados da área levantados por DEHAINI (1995), associados aos dados da avaliação preliminar do Lixão do Alvarenga, confrontou-se e comprovou-se a validade da metodologia para a água subterrânea. Cabe chamar a atenção para o fato de que Dehaini (1995) 
realizou trabalho comparando a investigação geofísica aos dados de análises químicas provenientes de 16 cacimbas existentes a jusante do lixão.

Assim, a metodologia aqui apresentada indica que devem ser tomadas medidas que visem a caracterização das áreas priorizadas na etapa da avaliação preliminar, para posteriormente traçar diretrizes para a remediação destas áreas.

$\mathrm{Na}$ área do Lixão do Alvarenga algumas intervenções imediatas podem ser definidas. A população que reside sobre a massa de lixo deve ser removida. Além do risco de doenças, esta população está assentada em áreas sucetíveis à ocorrência de explosões. No aspecto das águas superficiais, o chorume que escoa juntamente com a água de origem pluvial deve ser coletado e tratado, impedindo o seu acesso à Represa Billings. Na área à jusante do local de deposição, a água subterrânea está contaminada. Razão pela qual, a população que utiliza esta água através de cacimbas deve receber água da rede pública de abastecimento.

Paralelamente a estas ações, a área do Lixão de Alvarenga deve passar por um processo de caracterização para que possam ser delineadas medidas para recuperação da área visando a proteção dos recursos ambientais.

\section{CONCLUSÕES}

Conforme proposto no objetivo deste trabalho os critérios para a gestão de áreas suspeitas ou contaminadas por resíduos sólidos foram claramente estabelecidos neste trabalho tanto pela elaboração da metodologia como pela sua aplicação. Além disso a metodologia elaborada demonstra-se como uma importante ferramenta disponível para a comunidade técnicocientífica para ser aplicada na questão das áreas contaminadas.

Para as áreas de disposição de resíduos sólidos foram estabelecidos critérios desde a classíficação e priorização destas áreas como também para a avaliação confirmatória. A validade destes critérios foram testados e comprovados através da aplicação na RMSP e Lixão do Alvarenga, portanto em duas escalas de trabalho distintas, a regional e a local.

Os locais de disposição de resíduos sólidos merecem dois níveis de intervenção por parte dos órgãos de governo. O primeiro, de caráter imediato e emergencial, relaciona-se com a saúde e 
vida da população. Nas áreas de disposição devem ser tomadas medidas imediatas visando a retirada da população que vive e trabalha como catadores. Da mesma forma, as residências que se localizam no local ou imediatamente adjacente ao depósito de lixo devem ser removidas, como já foi mencionado há risco de doenças e de explosões que podem ocorrer em função dos gases que migram e se acumulam na área de deposição e adjacências. A utilização da água superficial e/ou subterrânea contaminada é outro grande problema que deve ser solucionado imediatamente com o fornecimento de água dentro dos padrões de qualidade estabelecidos.

$\mathrm{O}$ segundo nível de intervenção diz respeito à proteção dos recursos ambientais. As áreas priorizadas devem ser caracterizadas nos meios ar, solo, água superficial e subterrânea para definir ações necessárias para recurperá-las, conforme descrito na Parte 1 desta tese.

O trabalho desenvolvido nesta tese restringe-se tão somente às áreas de disposição de resíduos. Para concretizar a implementação do Programa de Gestão de Áreas Contaminadas é necessário ampliar a avaliação para um elenco maior de fontes de contaminação tais como postos de serviços, áreas industriais, áreas comerciais, áreas agrícolas e outras atividades. 


\section{BIBLIOGRAFIA}

ANDRADE, A.C. 1996. Sistemas de Avaliação de Prioridades para Recuperação de Áreas Contaminadas por Resíduos Perigosos. São Paulo. 98p. Dissertação de Mestrado. Faculdade da Saúde Pública. USP.

ALLERT, L; BENNET, T.; LEHR, J.H.; PETTY, R.J. 1987. DRASTIC: a standardized system for evaluating groundwater pollution potential using hydrogeologic setting. USEPA Report $600 / 2-85 / 018$

BERNARDES JR, C; HIRATA, R; MENDES, J; CLEARY, R. 1991. Remedial action for a industrial open dump. Proposed activities and prospectives. Wat. Sci. Tech (24).

BROWNELL, R.P. \& STUBING, H.D. 1982. Comprehensive approach to landfill leachate treatment. In: Proceedings of the National Conference on Environmental Engineering. Mineapolis, Minnesota. U.S.A

BULL, P.S.; EVANS, R.M.; WESCHSLER, R.M.; CLELAND, K.J. 1983 Biological Technology of the treatment of leachates from sanitary landfills. Water Research. 17(11):1473.

DUARTE, U. 1980. Geologia Ambiental da Área de São Pedro (SP). Vetor águas subterrâneas. São Paulo. Tese de doutoramento. IG/USP

CANADIAN COUNCIL OF MINISTERS OF THE ENVIRONMENT (CCME). 1992. National classification system for contaminated sites. Ottawa, Ontario. Canada. $54 \mathrm{p}$.

CASTRO NETO, P.; BARROTTI, A; BERNARDES, C.; TOSHIMITSO, J. 1984. Aterro sanitário da Cyanamid Química do Brasil Ltda (fábrica de Resende). In CONG BRAS ÁGUAS SUBTERRÂNEAS, 3, Fortaleza, 1984, Anais ... Fortaleza, ABAS, p 144-156

CENTRO DE PESQUISA DE ÁGUAS SUBTERRÂNEAS (CEPAS). 1994. Diagnóstico hidrogeológico da Região Metropolitana de São Paulo. Relatório Final Convênio SABESP/CEPAS-IG-USP. $115 \mathrm{p}$.

CLEARY, R.W. 1989. Águas Subterrâneas. In: Engenharia Hidrológica, cap.5, № 2. Coleção ABRH de Recursos Hídricos. Ed. UFRJ. Rio de Janeiro. p. 293-404. 
COMPANHIA DE SANEAMENTO BÁSICO DO ESTADO DE SÃo PAULO (SABESP). 1995. Relatório Síntese SAM-75. Encibra S.A. Estudos e Projetos de Engenharia.

COMPANHIA DE TECNOLOGIA DE SANEAMENTO AMBIENTAL (CETESB). 1987. Apresentação de Projetos e Aterros Industriais. São Paulo.

COMPANHIA DE TECNOLOGIA DE SANEAMENTO AMBIENTAL (CETESB). 1992a. Relatório de qualidade ambiental no Estado de São Paulo. Série Relatórios. 59p.

COMPANHIA DE TECNOLOGIA DE SANEAMENTO AMBIENTAL (CETESB). 1992b. Inventário de Locais de Destinação de Resíduos sólidos na Região Metropolitana de São Paulo (Relatório Interno). Diretoria de Controle das Regióes Metropolitanas.

COMPANHIA DE TECNOLOGIA DE SANEAMENTO AMBIENTAL (CETESB). 1997. Cadastro de Área Contaminadas. Projeto Recuperação do Solo e das Águas Subterrâneas em Áreas de Disposição de Resíduos Industriais. GTZ/CETESB/IG. São Paulo

COMPANHIA DE TECNOLOGIA DE SANEAMENTO AMBIENTAL (CETESB). Prelo. Manual de Áreas Contaminadas. CETESB/GTZ/IG.

CONSONI, A.J. 1993. Seleção de áreas para disposição de resíduos sólidos urbanos e proposta de aterro sanitário no município de Iguape, SP. São Paulo: IPT.

CUMMINS, M.D. 1981. Effect of sanitary landfill leachate on the activated sludge process. In: Proceedings of the seventh Annual Research Symposium, Land Disposal: Municipal Solid Waste. Philadelphia. Pennsylvania.

DEPARTAMENTO DE ÁGUAS E ENERGIA ELÉTRICA (DAEE). 1975. Estudo de águas subterrâneas, Região Administrativa 1. 220p.

DEHAINI, J. 1995. Avaliação da Aplicabilidade de Métodos Geofisicos em Estudos de Casos de Contaminação de Águas Subterrâneas por Diferentes Fontes. Dissertação de Mestrado. IG/USP.

FOSTER, S. \& HIRATA, R. 1988 Groundwater pollution risk evaluation: the methodology using available data. CEPIS-PAHO/WHO. Lima, 78p. 
GRAHAM, D.W. 1981. Biological-chemical treatment of landfill leachate. Master's Thesis, Department of Civil Engineering, University of British Columbia, Vancouver, British Columbia, Canada.

GUIGUER, N. 1987. Poluição das águas subterrâneas causada por um aterro sanitário: uma abordagem matemática - experimental. Dissertação de Mestrado (Escola Politécncia - USP).

HAGERTY, D.; PAVONI, L.; HEER, J. 1973. Solid Waste Management. Van Nostrand Reinhold. New York, NY. 242-262p.

HINSWEISE ZUR ERMITTLUNG UND SANIERUNG VON ALTLASTEN.(ISAL) 1991. Ministerium fulr Unwelt, Raumordaung und ILandwirtschaft und Lander. Nordrhein-Westfalen

HIRATA,R; BASTOS,C.; ROCHA,G.; IRITANI,M.; GOMES,D. 1991. Groundwater Pollution Risk Vulnerability Map of the São Paulo State - Brasil. Water Sci. Tech. 24:236-246.

HIRATA, R; BASTOS,C; ROCHA, G. 1992. Mapa de vulnerabilidade e risco de poluição das águas subterrâneas do Estado de São Paulo. Relatório Final. IG, CETESB, DAEE. São Paulo, 2v.

HIRATA,R. 1994. Fundamentos e Estratégias de Proteção e Controle da Qualidade das Águas Subterrâneas. Estudo de Casos no Estado de São Paulo. Tese de Doutoramento. IG/USP

INSTITUTO DE PESQUISAS TECNOLÓGICAS (IPT). 1994. LIXO MUNICIPAL - Manual de gerenciamento integrado. São Paulo. 278p.

LE GRAND, H.E. 1964. System for Evaluating the Contamination Potential of Some Wastes Sites, Amerciam Water Works Association Journal, Vol 56, No 8, pp. 959-974

MINISTERIUM FÜR UMWELT BADEN-WÜRTTEMBERG (MUBW). 1989. AltlastenHandbuch. Teil I. Altlasten-Bewertung. Baden-Württemberg. 128p.

MINISTRY OF INTERNATIONAL TRADE AND INDUSTRY. (MITI). 1994. Summary of results from nationwide research on industrial waste discharge by manufacturers. Japão.

POHLAND, F.G. 1980. Leachate recycle as a management option. In: Proceedings of Leachate Management Seminar. University of Toronto. Toronto. Ontario. 
SEADE .1995. Perfil Municipal do Estado de São Paulo. Reltório Anual. 1 Disquete. São Paulo

USEPA. 1989. Requirements for Hazardous Waste Landfill Design, Construction, and Closure. Seminar Publication. U.S. Environmental Protection Agency, Office of Technology Transfer, Cincinnati, $\mathrm{OH}$.

USEPA. 1991. Site Characterization for Subsurface Remediation. Seminar Publication. U.S. Environmental Protection Agency, Office of Research and Development, Cincinnati, $\mathrm{OH}$.

USEPA. 1992. The Hazard Ranking System. U.S. Environmental Protection Agency. 201p.

USEPA. 1994. Design, Operation, and Closure of Municipal Solid Waste Landfills. Seminar Publication. Washington, D.C., U.S.A. 86p. 


\section{ANEXO 1 \\ FICHA CADASTRAL E FICHA DE PONTUAÇÃO}




\section{FICHA CADASTRAL DE ÁREAS CONTAMINADAS}

\section{IDENTIFICAÇÃO DA ÁREA}

$1.1 N^{\circ}$ de cadastro: D0001101

1.2 Data da inspeção: 23.06 .94

Data de atualização:

1.3 Inspetores: Seiju, Wagner e Júlia

1.4 Denominação atual do local: Lixão do Alvarenga

1.5 Endereço: Estrada do Alvarenga/ Estrada das Volta s/n

Bairro: Jardim Bela Vista (Bairro dos Alvarengas)

Municipio: Diadema/ São Bernardo do Campo

1.6 Proprietário Atual : Prefeitura Municipal de Diadema e São Bernardo do Campo

1.7 Latitude [ 7.373.700] Longitude [ 335.300 ] Folha Topográfica: 3345

1.8 Tipo de fonte de contaminação: [1 ]
(1) Disposição de Resíduos
(2) Área Industrial
(3) Área Comercial
(4) Posto de Serviço
(5) Outras Fontes
(6) Não conhecida
(Preencher item 2)
(Preencher item 3)
(Preencher item 3)
(Preencher item 3)
(Preencher item 4)
(Preencher item 4)

1.9 Cód. da Atividade IBGE

Descrição

1.10 Situação atual quanto ao funcionamento

[ $\mathbf{x}$ ] Ativa(0)

desde: 01/01/79

[ ] Desativada(o)

funcionamento de até

1.11 Denominação anterior da área

1.12 Área total da propriedade ou área afetada: $\mathbf{3 5 0 . 0 0 0}\left(\mathrm{m}^{2}\right)$

1.13 Classificação da área

Classificação: (1) Área Potencial

(2) Área Suspeita

(3) Área Contaminada

(4) Área Excluída
Motivo:

Data
(1) Identificação de AP

(2) Avaliação Preliminar

(3) Investigação Confirmatória

(4) Remediação

Classificação



Motivo 


\section{DISPOSIÇÃO DE RESÍDUOS}

2.1 Tipo de Disposição [ 5 ]
(1) Aterro Controlado
(2) Aterro Sanitário
(3) Aterro Industrial
(4) Aterro de Entulhos
(5) Lixão
(6) Bota fora

2.2 Volume estimado de resíduos: 5.250 .000 metros cúbicos (CP1)

2.3 Tipos de Resíduos (CP1)

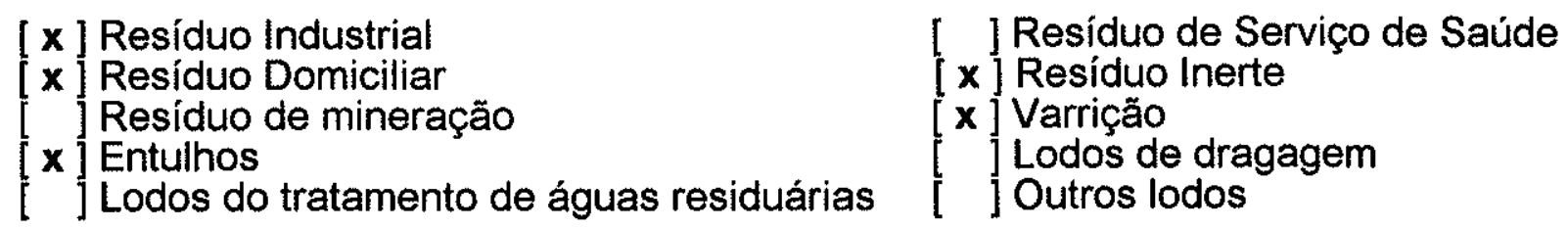

2.4 Tipos de Resíduos Industriais:

\begin{tabular}{|c|c|}
\hline Denominação & Quantidade \\
\hline $\begin{array}{l}\text { Borra de óleo } \\
\text { Amianto } \\
\text { Lona de freio } \\
\text { Plásticos } \\
\text { Borrachas }\end{array}$ & \\
\hline
\end{tabular}

2.5 Disposição desenvolvida [ 1 ]
(1) acima da superfície do terreno
(2) abaixo da superfície do terreno
(3) acima e abaixo da superfície do terreno

Altura:acima: $50 \mathrm{~m}$ abaixo: metros estimados

2.6 Existência de impermeabilização inferior (PAS)

$\left\{\begin{array}{l}\mathbf{x}] \text { inexistente } \\ \text { argila e membrana } \\ \text { ] argila }\end{array}\right.$

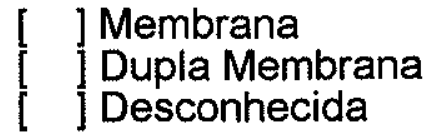

2.7 Recobrimento operacional [ 2 ]
(1) $\mathrm{Sim}$
(2) Não
(3) Desconhecido

2.8 Operação de compactação [ 2 ]
(1) Sim
(2) Não
(3) Desconhecido

2.9 Existência de drenagens:
(1) $\mathrm{Sim}$
(2) Não
(3) Desconhecido

[ 2 ] de águas de escoamento superficial

[2] de líquidos percolados

$\left[\begin{array}{l}2 \\ \mathbf{x}\end{array}\right]$ de nascentes

2.10. Destino dos líquidos percolados (PAS) 
[ $x$ ] Água superficial

x ] Infiltraçăo no solo

] Infiltração em poços

Estaçäo de tratamento de esgotos

] Estação de tratamento própria

2.11 Tipo de sistema de tratamento de líquidos percolados
[ $x$ ] Inexistente
Lagoas com impermeabilização
Filtros
Outros
[ ] $\begin{aligned} & \text { Recirculação } \\ & \text { Digestor Anaeróbio }\end{aligned}$

2.12 Existência de catadores no local [ 3 ]
(1) Não
(2) menos de 5
(3) de 5 a 50
(4) mais de 50

2.13 Operação de impermeabilização superior [ 1 ]
(1) inexistente
(2) parcial
(3) total com fraturas
(4) total

2.14 Material de impermeabilização superior (PS) [ 1 ]
(1) inexistente
(2) aterro argiloso
(3) aterro arenoso
(4) membrana
(5) dupla membrana
(6) argila e membrana
(7) pavimentação com asfalto/cimento
(8) desconhecido 


\section{3. ÁREA INDUSTRIAL/COMERCIAL}

3.1 Tipo de atividade industrial/comercial (CP1)

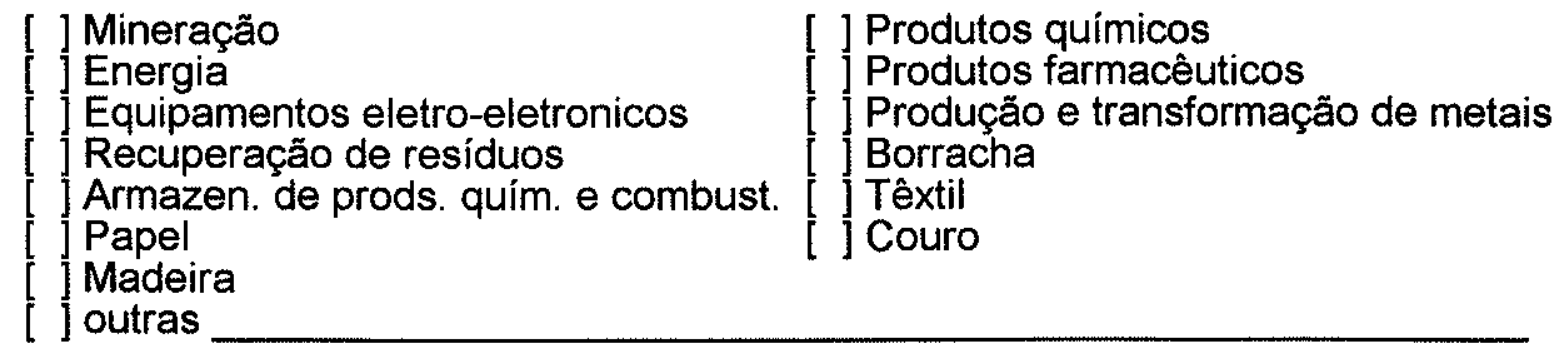

3.2 Fonte potencial de contaminação:

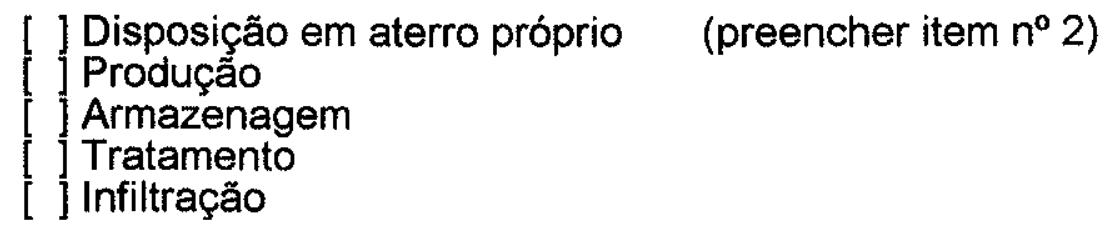

3.3 Número de funcionários:

\subsection{Materiais utilizados/produzidos/armazenados}

Tipo de Material: (MP)Máteria prima (PP)Produtos produzidos (OM)Outra Máteria

Armazenamento: (TE)Tanques enterrados (TA)Tanques aéreos (GA)Galpão (DC)depósito a céu aberto (OU)Outros

Denominação

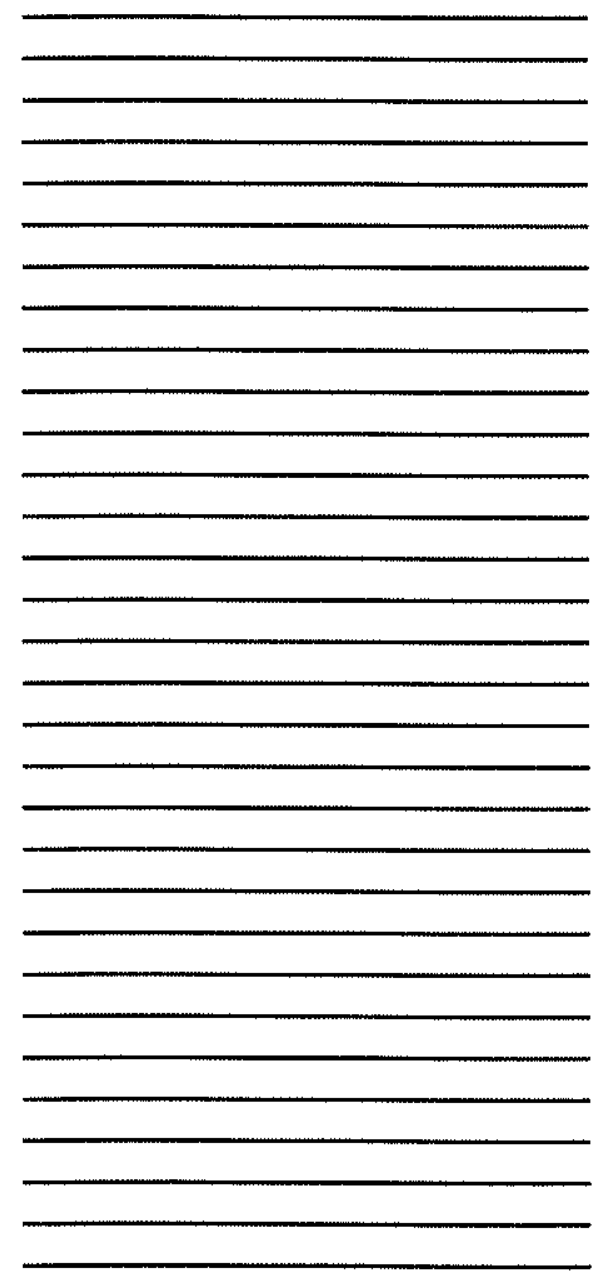

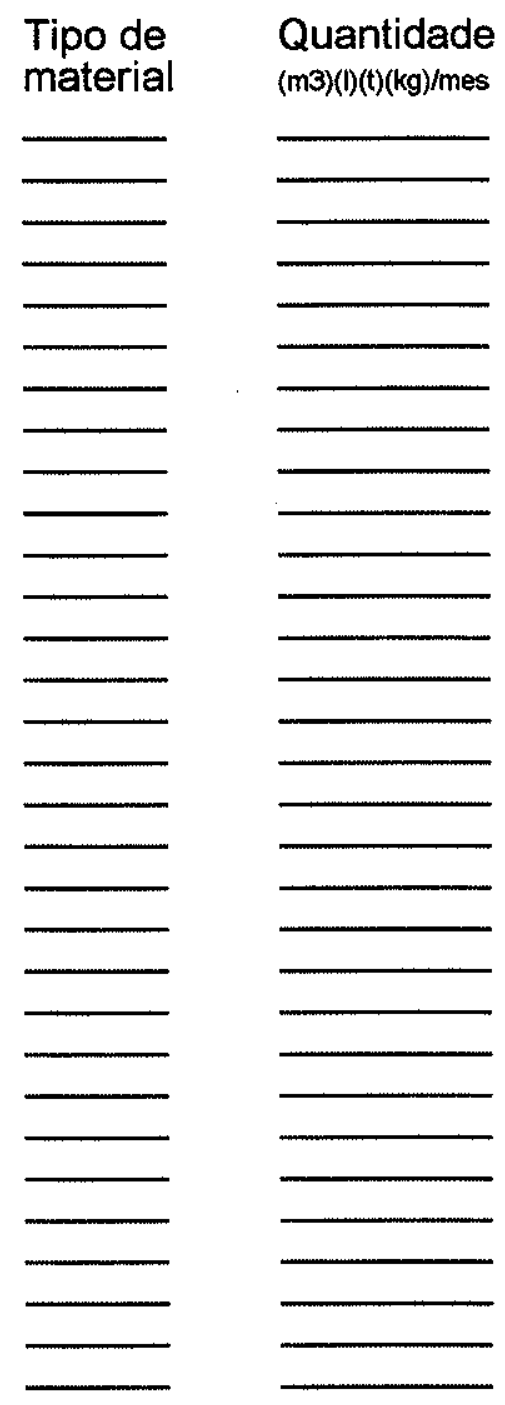

Armazenamento

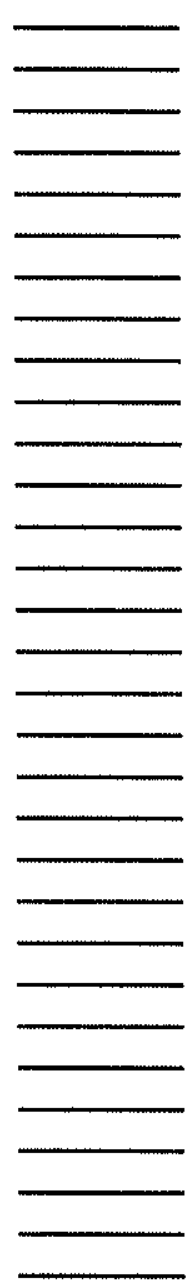




\subsection{Resíduos Gerados:}

Acondicionamento: (EO1)Tambor de 200 I (EO2)A Granel (EO3)Caçamba (EO4)Tanque (EC5)Tambores outros

(E06)Fardos (E07) Sacos plásticos (E08)Outras formas (E98)Inexistente (E99)Desconhecido

Armazenamento: (TE)Tanques enterrados (TA)Tanques aéreos (GA)Galpăo (DC)depósito a céu aberto (OU)Outros

Dest. final (não no local): (AT)Aterro terceiros (LF)Landfarming (VE)venda (OU)Outros

Dest.final (no local): (AT1) Aterro (LF1)Landfarming (LA)Lagoa (PI)Poço de infilt. (IR)!rrigaçăo (CO)Compostagem (OU)Outros

Denominação

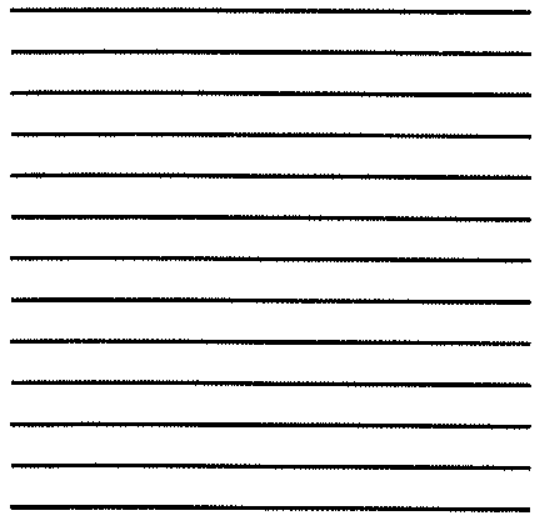

Quantidade $(\mathrm{m} 3)(\mathrm{l})(\mathrm{t})(\mathrm{kg}) / \mathrm{mes}$

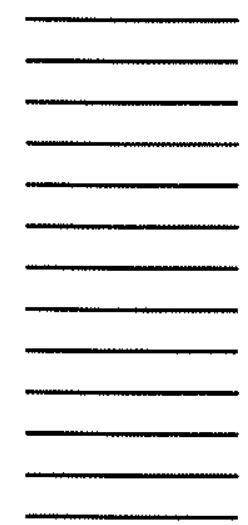

Acondi-

Armaze-

Dest cionam. namento final

3.6. Destino das águas residuárias (PAS)
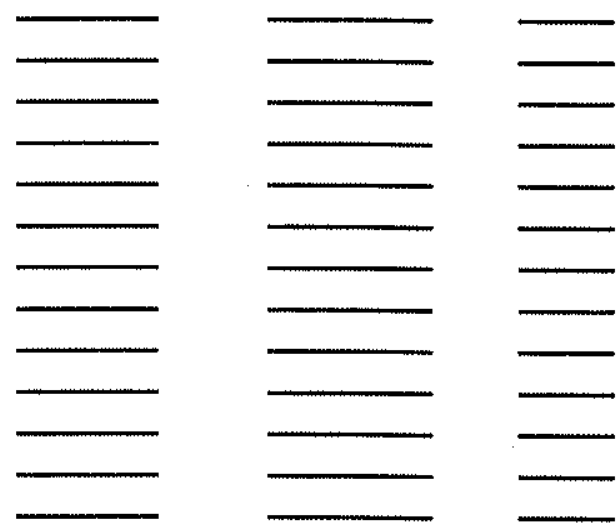

3.7 Tipo de sistema de tratamento de águas residuárias:
[ ] Inexistente
[ ] Lagoas com impermeabilização
Filtros
Outros
[ ] Recirculação

3.8 Condições de impermeabilização na área
(1) Boas
(2) Ruins

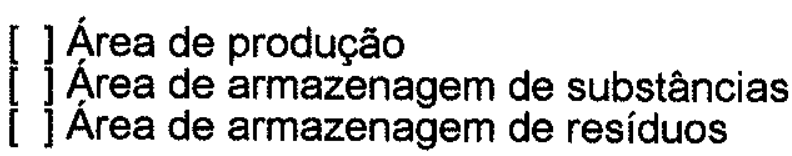

3.9. Impermeabilização da superfície do solo (PS) [ ]
(1) inexistente
(4) membrana
(2) aterro argiloso
(5) dupla membrana
(3) aterro arenoso
(7) pavimentação com asfalto/cimento
(6) argila e membrana
(8) desconhecido

3.10 Existência de vazamentos/infiltrações

$\begin{array}{ll}\text { [ ] Tanques de armazenamento } & \text { [ ] Tubulaçöes } \\ \text { [ No processo produtivo } & \text { [ ] Na ETE } \\ \text { [ No tratamento/armazenamento de resíduos } \\ \text { [ lnexistente }\end{array}$




\section{Outras Fontes / Fontes não conhecidas}

4.1. Tipo: [ ]
(1) Acidentes
(2) Atividade agrícola
(3) Outras
(4) Não conhecida

\subsection{Causa [ ]}

(1)Colisão/tombamento de veículos

(2)Corrosão de dutos

(3) Vazamentos

(4) Infiltração

(5) Outros

(6) Não conhecida

4.3. Data da Ocorrência:

\subsection{Material/Resíduo}

Denominação
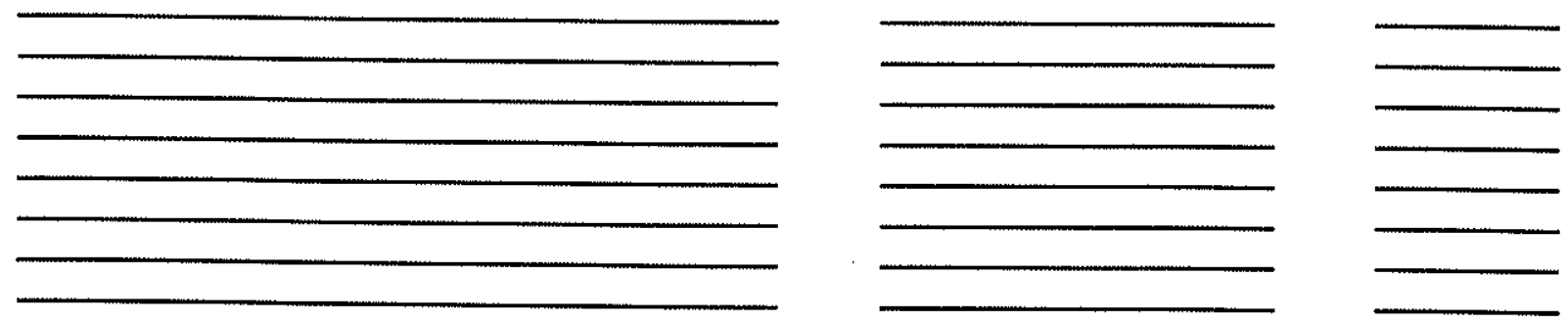

4.5. Destino das substâncias/material envolvidos (PAS)

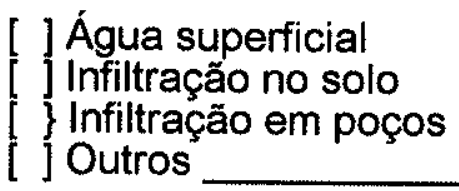

4.6. Existência de impermeabilização da superfície da área (PS) [ ]
(1) inexistente
(4) membrana
(2) aterro argiloso
(5) dupla membrana
(3) aterro arenoso
(7) pavimentação com asfalto/cimento
(6) argila e membra
(8) desconhecido 


\section{DESCRIÇÃO DA ÁREA E SUAS ADJACÊNCIAS (raio de $\mathbf{1 . 0 0 0 ~ m e t r o s ) ~}$}

5.1 Resíduos e/ou substâncias presentes na área (CP2)

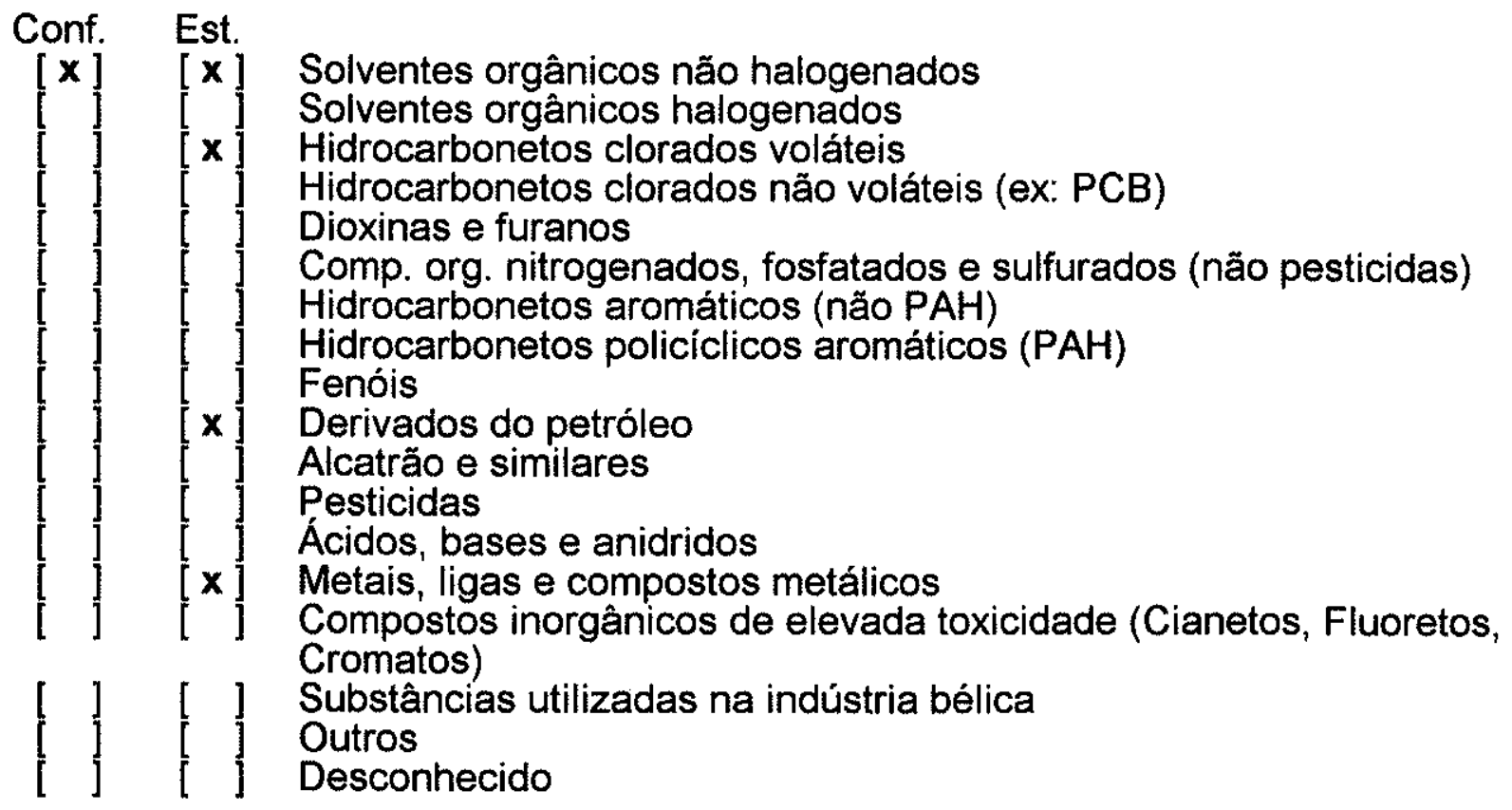

5.2 Ocupaçăo do solo/áreas com bens a proteger: (CP3)

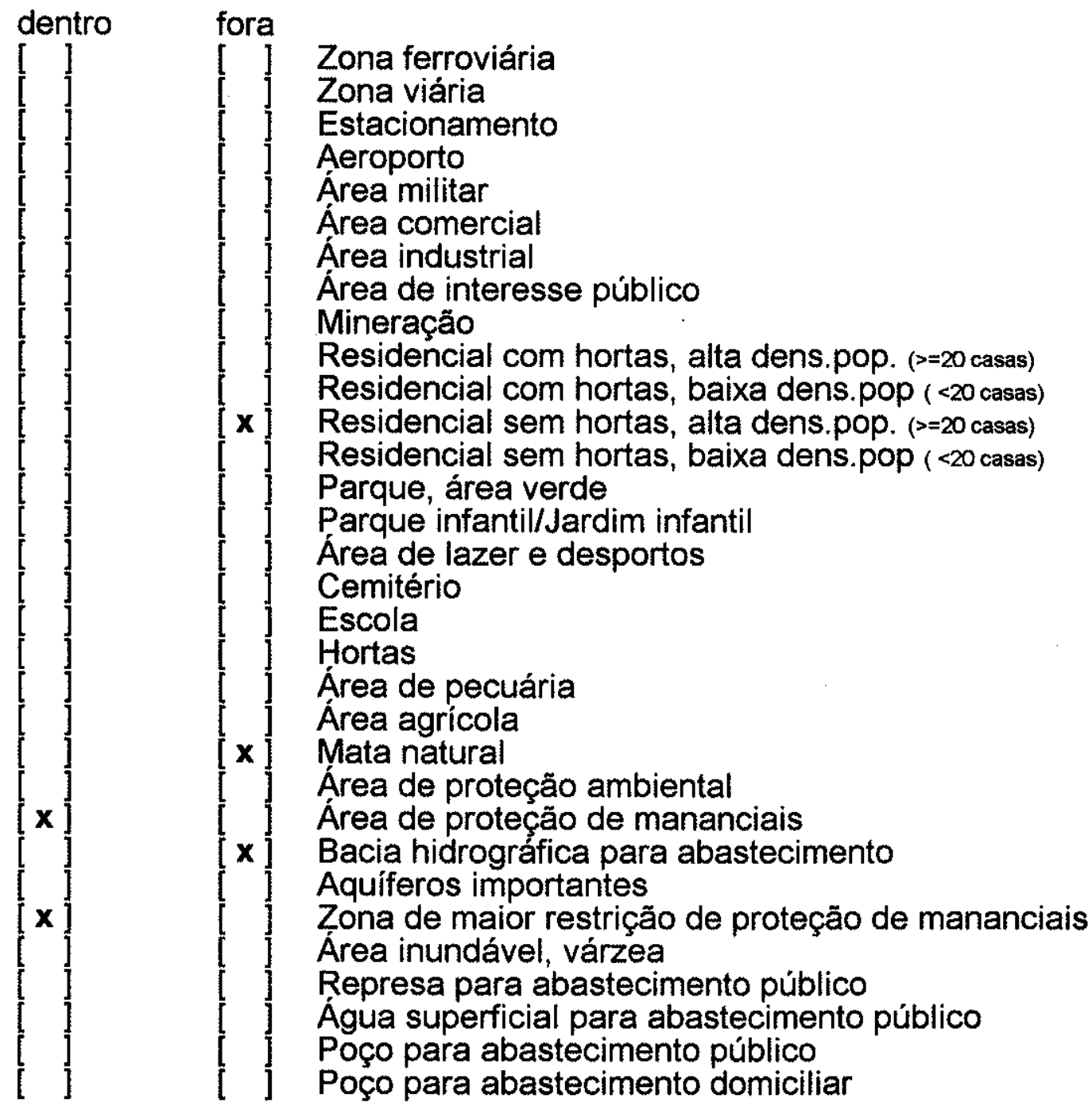


5.3 Uso atual da área:

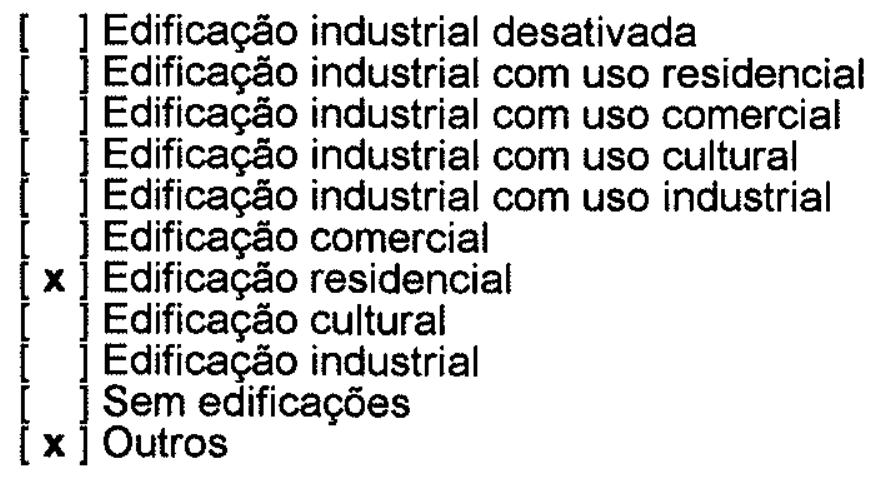

.4 Uso previsto para a área:

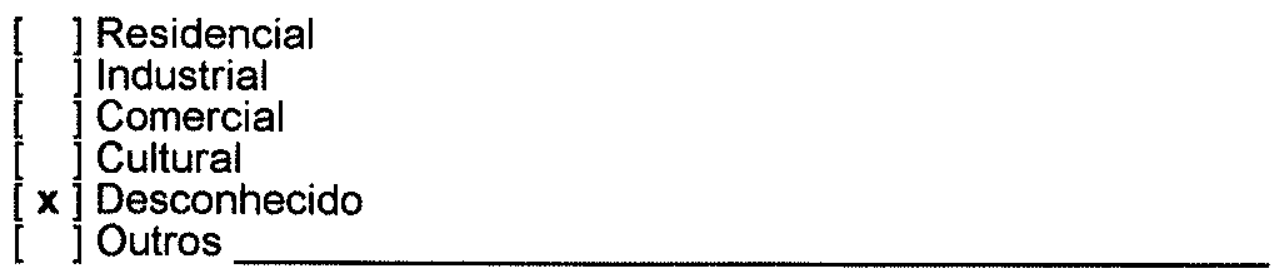

5.5.Distância até a edificação mais próxima da área [1] (PA)
(1) $<50 \mathrm{~m}$
(2) $50-100 \mathrm{~m}$
(3) $100 m-500 m$
(4) $>500 \mathrm{~m}$
(5) inexistente

5.6 Posição da área no relevo

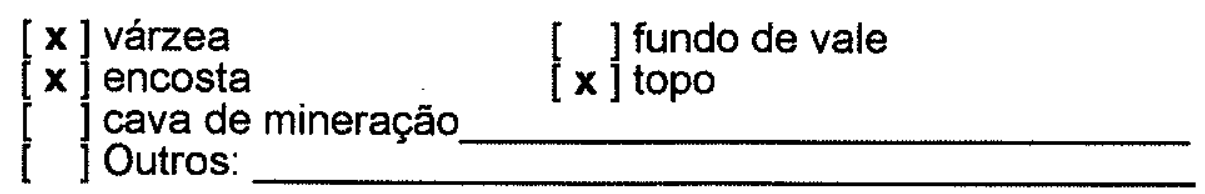

5.7 Textura predominante do solo [ 2 ] (PAS)
(1) argilosa
(2) arenosa
(3) siltosa

5.8. Resultado de análise de solo (PS)
(1) contaminado
(2) não contaminado
(3) análise não realizada
(4) desconhecida
3 ] profundidade 0 a $1 \mathrm{~m}$
[3] profundidade $>1 \mathrm{~m}$

5.9 Variação do nível da água subterrânea na área.

[ $\mathbf{x}$ ] inferida [ ] medida de 0 a $12 \mathrm{~m}$

5.10 Nível sazonalmente mais elevado da água subterrânea [1] (PAS)
(1) Em contato com o resíduo/solo contaminado
(2) Abaixo do resíduo/solo contaminado
(3) Desconhecida

5.11 Existência de água subterrânea contaminada por influência da área (confirmada por análise ou presença de produto/substância imiscivel) (PAS)
[ ] $\operatorname{sim}$
[ ] não
[ $\mathbf{x}$ ] desconhecida 
5.12 Uso da água subterrânea afetada pela contaminação(PAS)

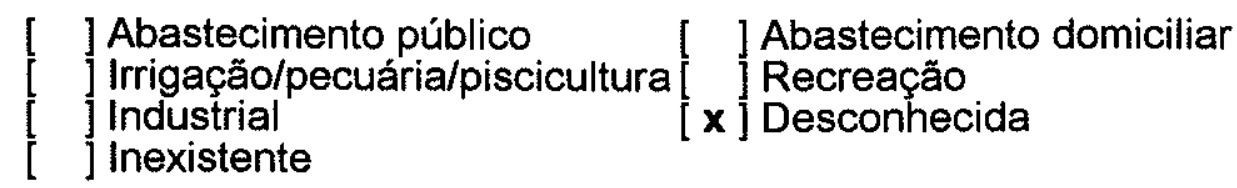

5.13.Contexto hidrogeológico da área [ 8-9 ] (PAS)
(1) Quaternário
(2) Terciário em área de recarga
(3) Terciário em área de descarga
(4) Cárstico
(5) Cristalino aflorante
(6) Cristalino com manto argiloso em área de recarga
(7) Cristalino com manto argiloso em área de descarga
(8) Cristalino com manto arenoso em área de recarga
(9) Cristalino com manto arenoso em área de descarga
(10) Desconhecido

5.14 Existência de água superficial contaminada por influência da área (confirmada por análise ou presença de produto/substância imiscivel) (PASP)

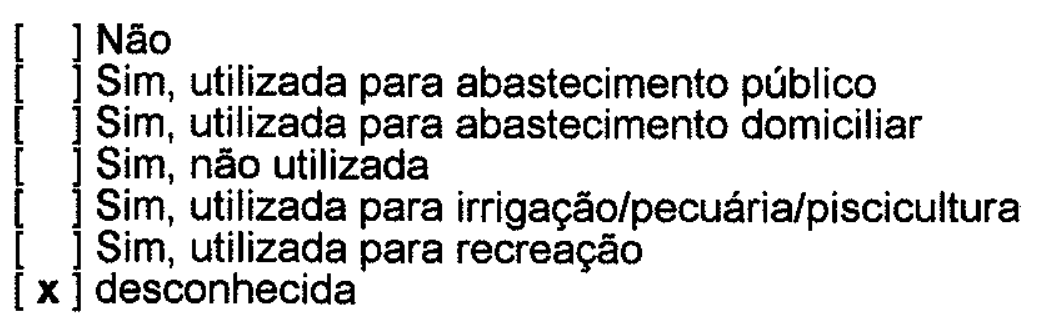

5.15 Possibilidade de influência direta da área sobre as águas superficiais (PASP)

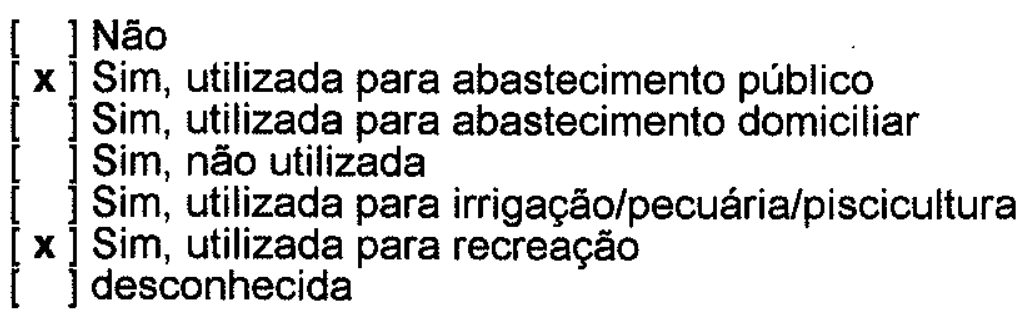

5.16 Possibilidade de enchente na área e uso da água superficial no local (PASP)

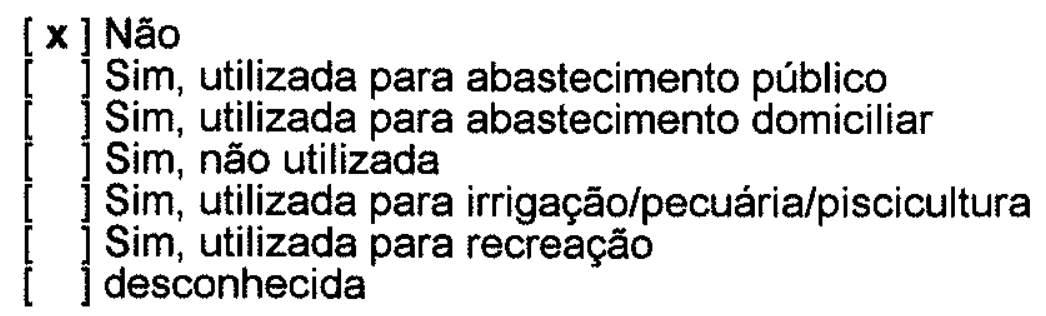

5.17. Qualidade do ar do solo na área [ 3 ] (PA)
(1) contaminada
(2) não contaminada
(3) análise não realizada
(4) desconhecida 


\section{EVENTOS IMPORTANTES / RISCOS COMPROVADOS}

6.1 Ocorrência de acidentes e/ou eventos importantes

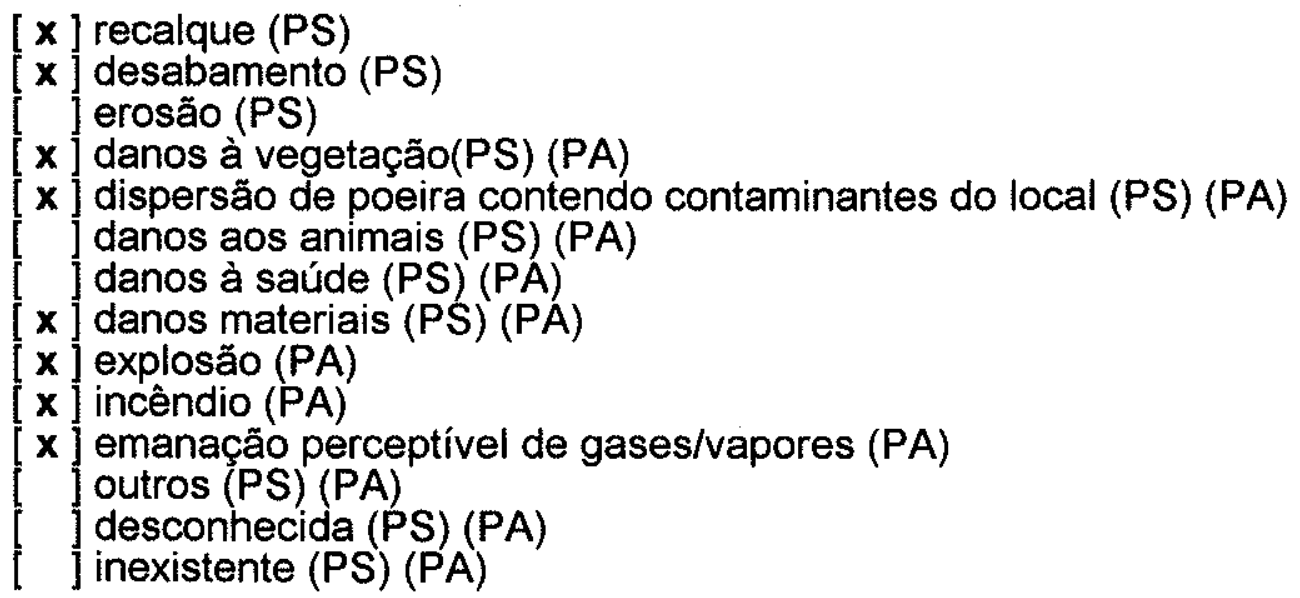

6.2 Erosão existente (tipo predominante) [ 3 e 4 ]
(1) inexistente
(2) laminar
(3) sulco
(4) ravina
(5) vossoroca

6.3 Existência de risco comprovado a respeito de contaminação do solo (PS)

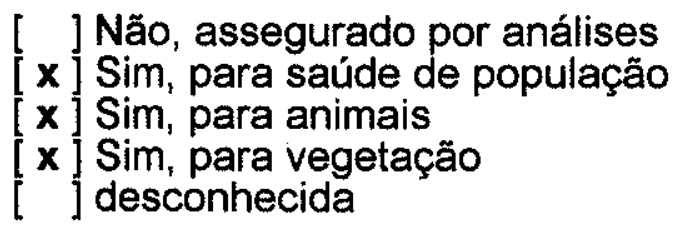

6.4 Indicações visiveis na superfície do solo (PS)

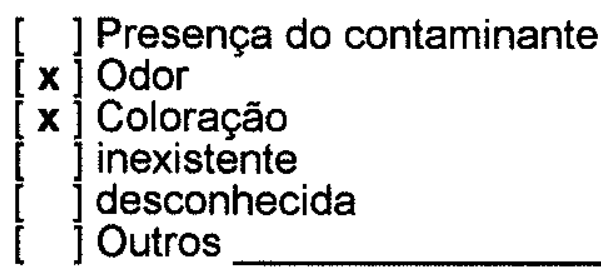

6.5. Presença de gases/vapores nas edificações vizinhas [ 3 ] (PA)
(1) $\mathrm{Sim}$
(2) Não
(3) Desconhecida 


\section{ATIVIDADES DESENVOLVIDAS NA ÁREA}

7.1 Investigação confirmatória: [ ] Sim [ x ] Não

Executante:

Data da início: Data de encerramento:

Resumo dos resultados: Substâncias
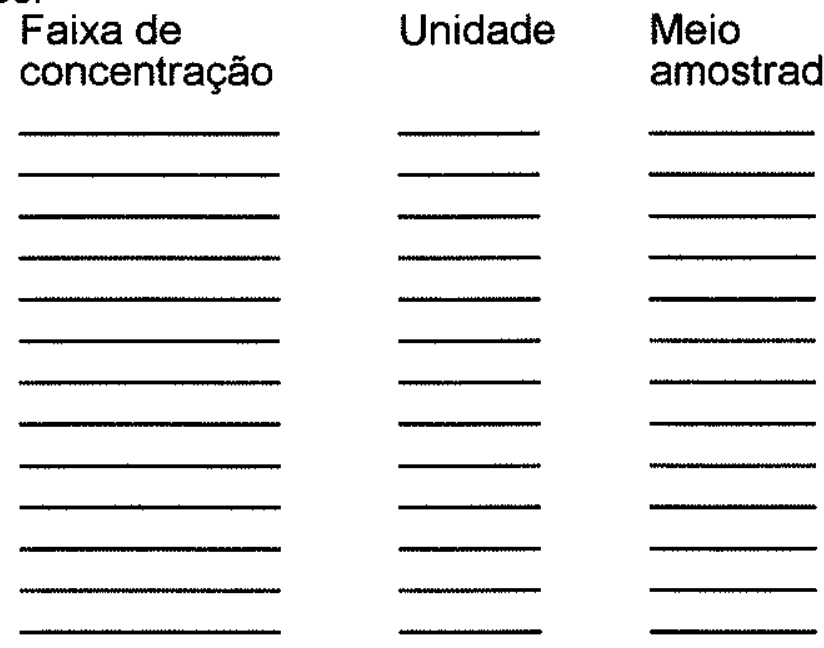
considerado

7.2 Investigação detalhada:

[ $] \operatorname{Sim}[\mathbf{x}]$ Não

Executante:

Data da início:

Data de encerramento:

7.3 Análise de risco:

[ ] $\operatorname{Sim}[\mathbf{x}]$ Não

Executante:

Data de início:

Data de encerramento:

Existência de risco à saúde:

[x] Sim [ ] Não

7.4 Remediação do local:

[ ] Sim [ $\mathbf{x}]$ Não

Firma executante:

Data de início:

Data de encerramento:

Técnicas empregadas: 
8. FONTES DE INFORMAÇÃO

$\left[\begin{array}{ll}{[\mathbf{x}]} & \text { CETESB } \\ {[\mathbf{x}]} & \text { Prefeituras } \\ {\left[\begin{array}{l}\text { Pessoas do local } \\ \text { Indústria }\end{array}\right.} & \text { Empresas } \\ {[\mathbf{x}]} & \text { Outras }\end{array}\right.$




\section{CRITÉRIO PRINCIPAL 1 - FONTES DE CONTAMINAÇÃO}

\begin{tabular}{|c|c|c|c|c|c|c|c|c|c|c|}
\hline Disposicã o: Tipos de Resíduos & Confirmado & Estimado & BP1 a BP6 & $\mathbf{M n}$ & BP1 & BP2 & $\mathrm{BP3}$ & BP4 & BP5 & $\mathrm{BP6}$ \\
\hline Residuo Industrial & 3 & & 3 & & & & & & & \\
\hline Resíduo de Serviço de Saúde & 3 & & 3 & & & & & & & \\
\hline Residuo Domiciliar & 2 & & 2 & & & & & & & \\
\hline Resíduo Inerte & 1 & & 1 & & & & & & & \\
\hline Resíduo de Mineraço & 1 & & & & & & & & & \\
\hline Vamiçăo & 1 & & 1 & & & & & & & \\
\hline Entulhos & 1 & & $\overline{1}$ & & & & & & & \\
\hline Lodos do Tratam. de Aguas Resid. & 2 & & & & & & & & & \\
\hline Lodos de Dragagem & 3 & & & & & & & & & \\
\hline \multirow[t]{2}{*}{ Outros Lodos } & 3 & & & & & & & & & \\
\hline & & & 3 & (x) $1,90=$ & 5,70 & $\mathbf{5 , 7 0}$ & 5,70 & $\mathbf{5 , 7 0}$ & 5,70 & 5,70 \\
\hline \multicolumn{4}{|l|}{$\begin{array}{l}\text { Volume de Disposiça de } \\
\text { Resíduos }\end{array}$} & & & & & & & \\
\hline$>1.000 .000 \mathrm{~m}^{3}$ & 3 & & 3 & & & & & & & \\
\hline $100.000-1.000 .000 \mathrm{~m}^{3}$ & 2 & & & & & & & & & \\
\hline \multirow[t]{2}{*}{$<100.000 \mathrm{~m}^{3}$} & 1 & & & & & & & & & \\
\hline & & & 3 & (x) $0,48=$ & 1,44 & 1,44 & 1,44 & 1,44 & 1,44 & 1,44 \\
\hline \multicolumn{4}{|l|}{ Grupos de Substancias } & & & & & & & \\
\hline Orgânicos halogenados voléteis & 3 & 2 & 2 & & & & & & & \\
\hline Orgánicos năo halog voláteís & 3 & $\overline{2}$ & 2 & & & & & & & \\
\hline Hidrocarb clorados voláteis & 3 & 2 & $\overline{2}$ & & & & & & & \\
\hline Aromáticos Cloredos (PCB) & 3 & 2 & & & & & & & & \\
\hline Diounas e Furanos & 3 & 2 & & & & & & & & \\
\hline $\begin{array}{l}\text { Compostos org. Nitrogenados, } \\
\text { Fosfatados, Sulfados (sem } \\
\text { Pesticidas) }\end{array}$ & 3 & 2 & 2 & & & & & & & \\
\hline Hidrocarb arom (sem PAH) & 3 & 2 & & & & & & & & \\
\hline $\begin{array}{l}\text { Hidrocartonetos Policiclicos } \\
\text { Aromáticos (PAH) }\end{array}$ & 3 & 2 & & & & & & & & \\
\hline Fendis & 3 & 2 & & & & & & & & \\
\hline Derivados de petróleo & 2 & 1 & 1 & & & & & & & \\
\hline Alcatrסes e produtos similares & 2 & 1 & & & & & & & & \\
\hline Pesticidas & 3 & 2 & & & & & & & & \\
\hline Metais e seus compostos & 3 & 2 & 2 & & & & & & & \\
\hline Compostos inorg. (sem metais) & 2 & 1 & 1 & & & & & & & \\
\hline $\begin{array}{l}\text { Compostos inorg (mais tóxicos: } \\
\text { Cianet, fluorados e cromados) }\end{array}$ & 3 & 2 & & & & & & & & \\
\hline outras substancias & 2 & 1 & 2 & & & & & & & \\
\hline desconhecida & 1 & 1 & 2 & & & & & & & \\
\hline & & & 2 & (x) $0,95=$ & 1,90 & 1,90 & 1,90 & 1,90 & 1,90 & 1,90 \\
\hline
\end{tabular}




\section{CRITÉRIO PRINCIPAL 2A- PROPAG. VIA SOLO}

\begin{tabular}{|c|c|c|c|c|c|c|c|c|c|c|c|c|c|c|}
\hline Andlise (0-1 m Prof) & $\mathrm{Rn}_{\mathrm{n}}$ & $\mathrm{BP1}$ & $\mathrm{BP2}$ & $\mathrm{BP3}$ & BP4 & BPS & BP6 & $\overline{\mathrm{Mn}}$ & $\mathrm{BP1}$ & $\mathrm{BP2}$ & $\overline{B P 3}$ & $\mathrm{BP} 4$ & BP5 & $\mathrm{BP6}$ \\
\hline Contaminado & 3 & &  & & 40:- & & & & & & & & & \\
\hline Năo contaminado & 0 & &  & & 2. & & & & & & & & & \\
\hline Análise nâ realizada & 2 & 2 & 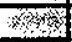 & 2 & n & 2 & 2 & & & & & & & \\
\hline Desconhecido & 2 & & 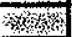 & & 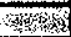 & & & & & & & & & \\
\hline & & 2 & 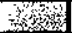 & 2 & 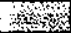 & 2 & 2 & (x) $0,5=$ & 1,0 & So & 1,0 & , & 1,0 & 1,0 \\
\hline
\end{tabular}

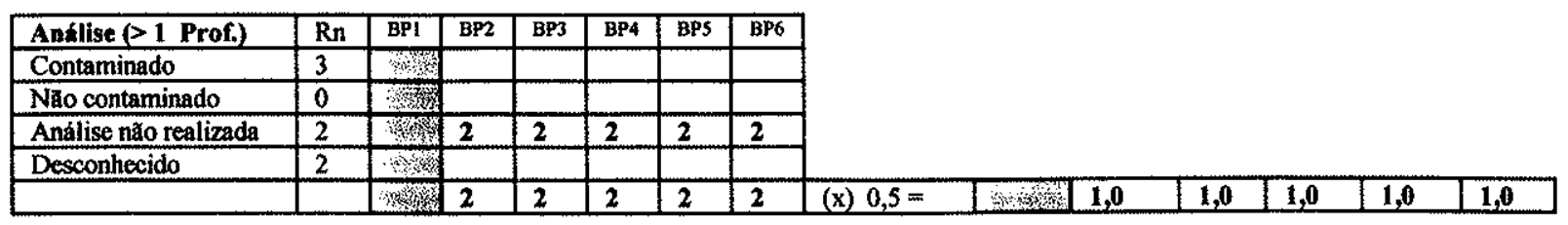

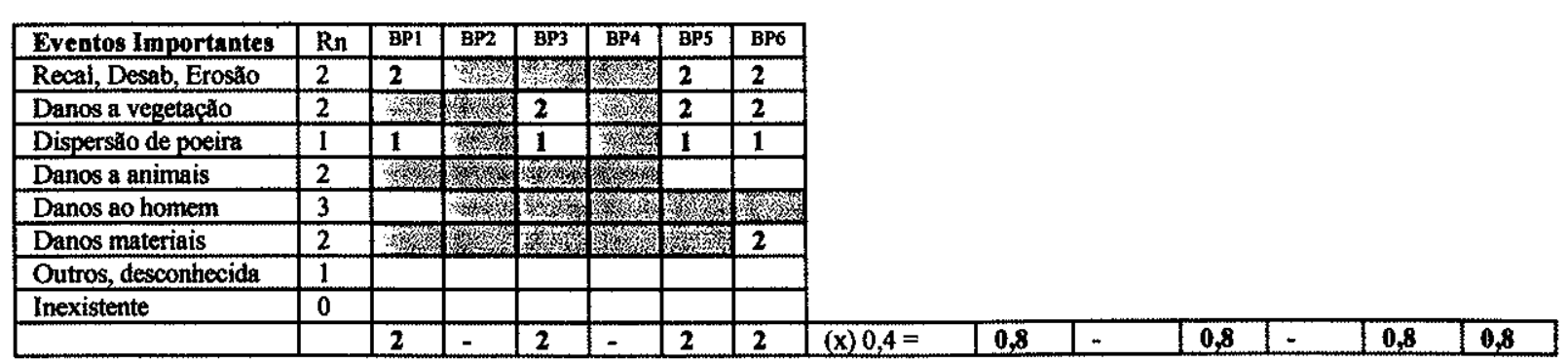

\begin{tabular}{|c|c|c|c|c|c|c|c|c|c|c|c|}
\hline Risco Compr (Solo) & $\mathrm{Rn}$ & $\mathrm{BPI}$ & BP2 & $\mathrm{BP3}$ & $\overline{8 P 4}$ & BP5 & $\mathrm{BP} 6$ & & & & \\
\hline Năo, asseg por anális & 0 & & W & & 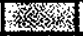 & & Fin & & & & \\
\hline Sim, p/saúde da pop. & 3 & 3 & rives & 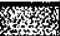 & 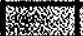 &  & 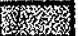 & & & & \\
\hline Sim, $\mathrm{p} /$ animais & $\overline{2}$ & 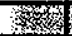 & 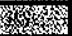 & 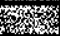 & 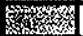 & 2 & 28 & & & & \\
\hline Sim, p/ vegetacalo & 2 & 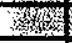 & 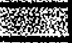 & 2 & 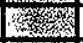 & 2 & rys & & & & \\
\hline Desconhecida & 2 & & 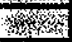 & & 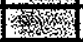 & & 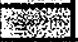 & & & & \\
\hline & & $\overline{3}$ & 3. & 2 & 3. & 2 & rat & (x) $0,6=$ & W & X & 䇝 \\
\hline
\end{tabular}

\begin{tabular}{|c|c|c|c|c|c|c|c|c|c|c|c|c|c|c|}
\hline Imperm. Superf. & $\mathbf{R n}$ & $\mathrm{BPI}$ & BP2 & $\mathrm{BP3}$ & BP4 & BP5 & BP6 & & & & & & & \\
\hline Memb, solo & 0 & & & & & & & & & & & & & \\
\hline Pav. (asfalto ou cimen) & 1 & 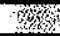 & & Whath & & rey & & & & & & & & \\
\hline Aterro argiloso & 2 & 3. & & & & & & & & & & & & \\
\hline Aterro arenoso & 3 & 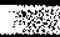 & & & & & & & & & & & & \\
\hline Inexistente, desconhec. & 3 & 3 & 3 & 3 & 3 & 3 & 3 & & & & & & & \\
\hline & & 3 & 3 & 3 & 3 & 3 & 3 & (x) $0,6=$ & 1,8 & 1,8 & 1,8 & 1,8 & 1,8 & 1,8 \\
\hline
\end{tabular}

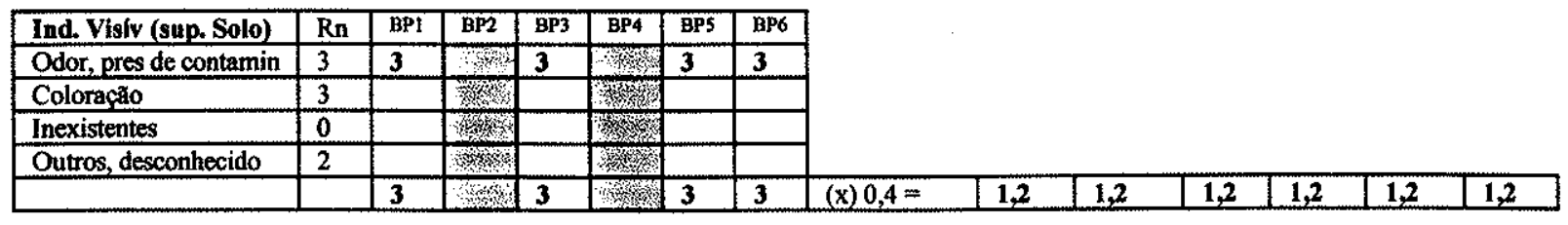

\begin{tabular}{|l|l|l|l|l|l|}
\hline 6,6 & 2,8 & 7,0 & 2,8 & 7,0 & 5,8 \\
\hline
\end{tabular}




\section{CRITÉRIO PRINCIPAL 2B - PROPAG. VIA ÁGUA SUPERFICIAL}

\begin{tabular}{|c|c|c|c|c|c|c|c|c|c|c|c|c|c|c|}
\hline Qualidade & $\mathrm{Rn}$ & $\mathrm{BPI}$ & $\overline{\mathrm{BP} 2}$ & BP3 & $\overline{B P 4}$ & BP5 & BP6 & $\mathrm{Mn}$ & $\mathrm{BPI}$ & $\mathrm{BP2}$ & $\mathrm{BP3}$ & BP4 & BP5 & BP6 \\
\hline Não, utilizada & 0 & ?m & Whe & 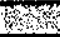 & & Whe & & & & & & & & \\
\hline Sim, util abast público & $\overline{3}$ & 3 & 3 & 3 & 3 & Sant & 3 & & & & & & & \\
\hline Sim, util abast domicil & 3 & & & 4 & & risting & & & & & & & & \\
\hline Sim, não utilizada & 1 & St & 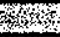 & Fin & & 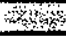 & & & & & & & & \\
\hline Sim util irrig, pec, pisc & 2 & 个n & Sy & Fis & 2 & 2 & 2 & & & & & & & \\
\hline Sim, util recreacáo & 3 & 3 & 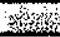 & y & 3 & 3 & 3 & & & & & & & \\
\hline Desconhecida & 2 & & & 5 & & & & & & & & & & \\
\hline & & 3 & 3 & 3ry & 3 & 2 & 3 & (x) $0,6=$ & 1,8 & 1,8 & & 1,8 & 1,2 & 1,8 \\
\hline
\end{tabular}

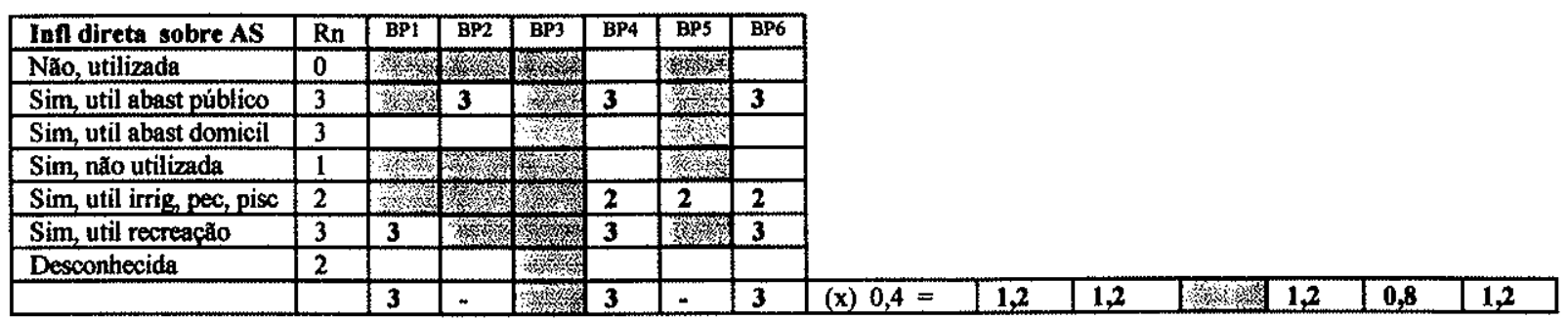

\begin{tabular}{|c|c|c|c|c|c|c|c|c|c|c|c|c|c|}
\hline Possib Enchente & $\mathbf{R n}_{\mathbf{n}}$ & $\overline{B P 1}$ & $\mathrm{BP2}$ & $\mathrm{BP3}$ & $\mathrm{BP4}$ & BP5 & Bp6 & & & & & & \\
\hline Nâo, utilizada & $\begin{array}{l}0 \\
0\end{array}$ & rex & 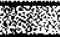 & 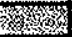 & $\overline{0}$ & 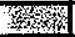 & $\mathbf{0}$ & & & & & & \\
\hline Sim util abast público & 3 & W & & (6) & & 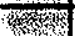 & & & & & & & \\
\hline Sim util abast domicil & 3 & & & 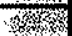 & & (3) & & & & & & & \\
\hline Sim, năo utilizada & 1 & (3) & rer &  & & 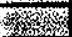 & & & & & & & \\
\hline Sim, util irrig, pec, pisc & 2 & 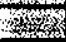 & 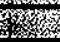 &  & & & & & & & & & \\
\hline Sim, util piscicultura & 3 & & $y$ & 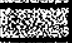 & & 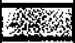 & & & & & & & \\
\hline Desconhecida & 2 & & & 3is & & & & & & & & & \\
\hline & & - & - & W & $\mathbf{0}$ & - & $\mathbf{0}$ & (x) $0,3=$ & - & - & 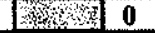 & - & 0 \\
\hline
\end{tabular}

Critério Principal 2 - Propag. Via Água Superficial

\begin{tabular}{|l|l|l|l|l|}
\hline $\mathbf{3 , 0}$ & $\mathbf{3 , 0}$ & $\mathrm{3}, \mathrm{r}$ \\
\hline
\end{tabular}




\section{CRITÉRIO PRINCIPAL 2C- PROPAG. VIA ÁGUA SUBTERRÂNEA}

\begin{tabular}{|c|c|c|c|c|c|c|c|c|c|c|c|c|c|c|}
\hline Contaminaçăo A Sub & $\mathrm{Rn}$ & $\overline{B P 1}$ & BP2 & $\mathrm{BP} 3$ & BP4 & BP5 & $\overline{B P 6}$ & $\mathrm{Mn}$ & BP1 & BP2 & aP3 & BP4 & BP5 & BP6 \\
\hline Sim & 3 & 1) & & 7\% & & सक & & & & & & & & \\
\hline Não & 0 & 番 & & nta & & 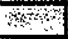 & & & & & & & & \\
\hline Desconhecida & 2 & काष & 2 & 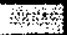 & 2 & 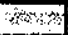 & 2 & & & & & & & \\
\hline & & $-\infty$ & 2 & 4 & 2 & एक & 2 & (x) $0,5=$ & $3 \mathrm{sidy}$ & 1,0 & 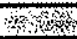 & 1,0 & W. & 1,0 \\
\hline
\end{tabular}

\begin{tabular}{|c|c|c|c|c|c|c|c|c|c|c|c|c|c|c|}
\hline Uso A Sub afet. cont & $\mathbf{R n}_{\mathbf{n}}$ & BP1 & $\mathrm{BP2}$ & $\mathrm{BP} 3$ & $\mathbf{B P 4}$ & BP5 & BP6 & & & & & & & \\
\hline Abastec público & 3 & $\cdots$ & & ? & & W & 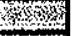 & & & & & & & \\
\hline Abastec domiciliar & 3 & 3 & 3 & 3 & $\mathbf{3}$ & 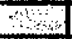 & 2rons & & & & & & & \\
\hline Recreacăo & 3 & & & S" & &  & 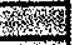 & & & & & & & \\
\hline Irrigagào, pecuária & 2 & 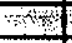 & 5 & Sy & & & 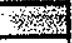 & & & & & & & \\
\hline Uso Industrial & 1 & 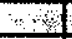 & 37? & \% & & ring & & & & & & & & \\
\hline Desconhecida & 2 & & & & & & & & & & & & & \\
\hline Inexjstente & 0 & का & & ए人 & & 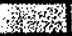 & 3ris & & & & & & & \\
\hline & & 3 & 3 & 3 & 3 & - & - & (x) $0,4=$ & 1,2 & 1,2 & 1,2 & 1,2 & - & $=$ \\
\hline
\end{tabular}

\begin{tabular}{|c|c|c|c|c|c|c|c|c|c|c|c|}
\hline Text pred do solo & $\mathrm{Rn}$ & $\mathrm{BP1}$ & $\mathrm{BP2}$ & $\mathrm{BP3}$ & $\mathrm{BP4}$ & BP5 & BP6 & & & & \\
\hline Arenosa, siltosa & 3 & 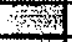 & 3 & S & 3 & 35 & 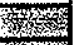 & & & & \\
\hline Argilosa & 1 & 36 & & ए人. & & is & 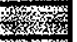 & & & & \\
\hline Desconhecida & 2 & 25is & &  & & 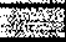 & 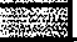 & & & & \\
\hline & & का & 3 & 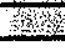 & 3 & 6) & 15) & $(x) 0,1=$ & \begin{tabular}{|l|l|} 
Din & 0,3 \\
\end{tabular} &  & T往 \\
\hline
\end{tabular}

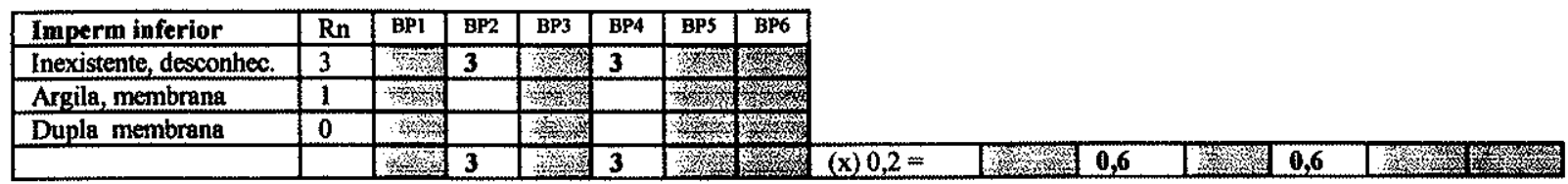

\begin{tabular}{|c|c|c|c|c|c|c|c|c|c|c|c|}
\hline Dest. Fin Lig Percol & $\bar{R} \mathbf{n}$ & $\overline{\text { BP1 }}$ & $\overline{B P 2}$ & $\begin{array}{ll}\mathrm{BP3} 3 \\
\end{array}$ & BP4 & BPS & BP6 & & & & \\
\hline Ag Sup, Solo ou Pocos & 3 & 78 & $\mathbf{3}$ & 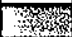 & $\mathbf{3}$ & N & 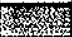 & & & & \\
\hline Estac. tratamento & 0 & 20. & & 3. & &  & 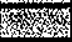 & & & & \\
\hline & & \% & 3 & 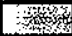 & 3 & 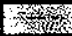 & 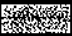 & $(x) 0,2=$ & 18 &  & 4 ; \\
\hline
\end{tabular}



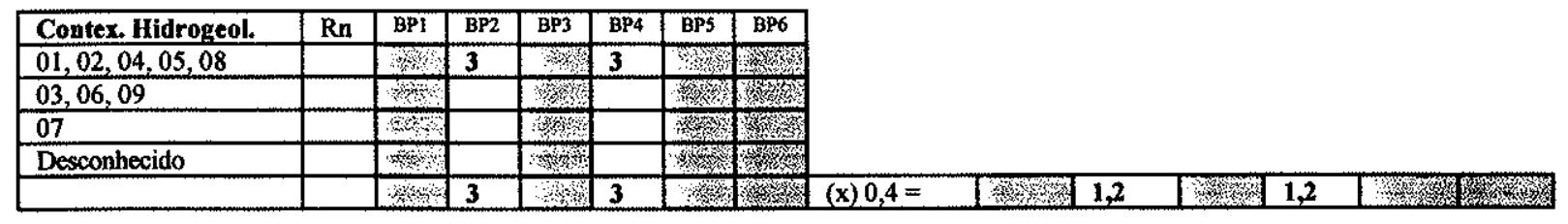

\begin{tabular}{|l|l|l|l|l|l|l|}
\hline Critério Principal 2 - Propag Via Ág. Subterrâneas & 1,2 & 5,2 & 1,2 & 5,2 & 0,0 & 1,0 \\
\hline
\end{tabular}






\begin{tabular}{|c|c|c|c|c|c|c|c|c|c|c|c|c|c|c|}
\hline Qual do ar do solo & $\overline{R n}$ & $\mathrm{BPI}$ & $\overline{B P 2}$ & BP3 & $\overline{\mathrm{BP} 4}$ & BP5 & BP6 & $\overline{M n}$ & BPI & $8 \times 2$ & $\mathrm{BP3}$ & $\mathrm{BP}^{\mathrm{P} 4}$ & BPS & $\overline{\mathrm{BP} 6}$ \\
\hline Análise não realizada & 2 & $\overline{2}$ & $\sqrt{20}$ & $\overline{2}$ & w & 2 & 2 & & & & & & & \\
\hline Contaminada & 3 & &  & & Wha & & & & & & & & & \\
\hline Não contaminada & 0 & & 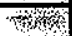 & & 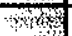 & & & & & & & & & \\
\hline Desconhecida & 2 & & sos & & 13 & & & & & & & & & \\
\hline & & 2 & ris & 2 &  & 2 & 2 & (x) $0,3=$ & $\overline{0,6}$ & 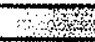 & 0.6 & Fas & 0,6 & 0,6 \\
\hline
\end{tabular}

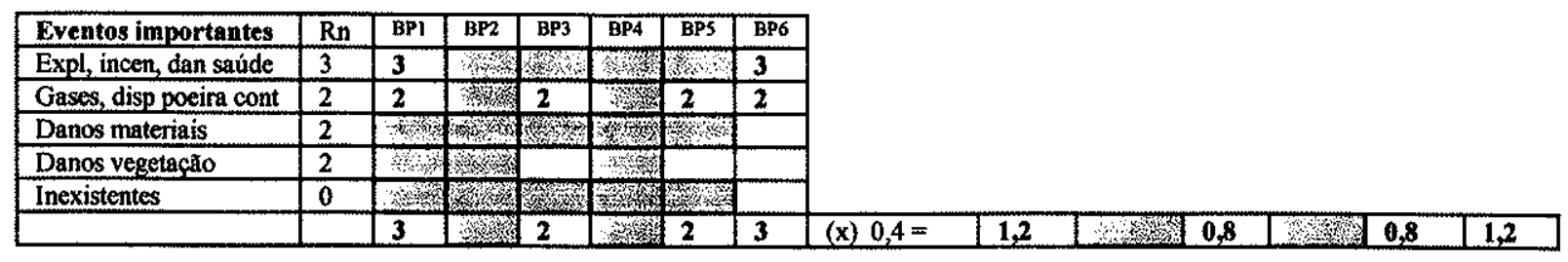

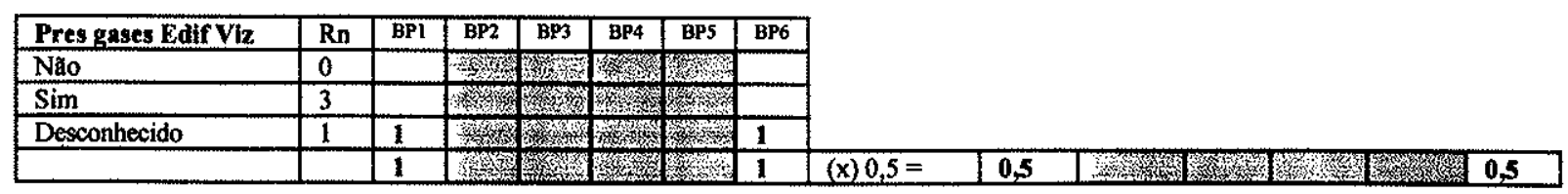



\begin{tabular}{|l|l|l|}
\hline 3,5 & - & 1,4 \\
\hline
\end{tabular}

\begin{tabular}{|l|l|}
\hline 1,4 & 3,5 \\
\hline
\end{tabular}




\section{CRITÉRIO PRINCIPAL 3A- BENS A PROTEGER}

\begin{tabular}{|c|c|c|c|c|c|c|c|c|c|c|c|c|c|c|}
\hline DENTRO DA AREA & $\overline{R n}$ & BP1 & $\mathrm{BP2}$ & BP3 & $\mathrm{BP4}$ & BP5 & BP6 & $\mathrm{Mn}$ & BPI & $\mathrm{BP2}$ & $\mathrm{BP3}$ & $\mathrm{BP4}$ & $\overline{\mathrm{BP} 5}$ & BP6 \\
\hline Zona ferroviéria & 1 & 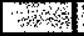 & rixy & 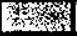 & Exy & $x+x=2$ & & & & & & & & \\
\hline Zona viéria & 1 & 3. & 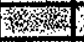 & S5 & W & 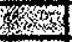 & & & & & & & & \\
\hline Estacionamento & 1 & S & 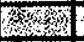 & 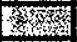 &  & W & & & & & & & & \\
\hline Aeroporto & 1 & S & 26ris & We. & 2 & 3 & & & & & & & & \\
\hline Area militar & 1 & w & Sy & 4 & 准 & 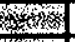 & & & & & & & & \\
\hline Comercial & 1 & W & y & 6 & 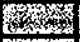 & 28 & & & & & & & & \\
\hline Industrial & 1 & w & - & 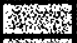 & a &  & & & & & & & & \\
\hline Area de interes públ & 1 & 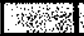 & 26) & Wret & 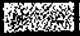 &  & & & & & & & & \\
\hline Mineracko & 1 & 3) & 5 & S &  & 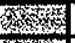 & & & & & & & & \\
\hline Res. Hortas (alt.pop) & 3 & & 18 & & 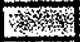 &  & & & & & & & & \\
\hline Res hortas (bai. pop) & 3 & & ; & & ber & 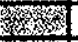 & & & & & & & & \\
\hline Res (alta dens. pop.) & 3 & & (3) & & 2 & 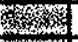 & & & & & & & & \\
\hline Res. (bai dens. poo.) & $\overline{3}$ & $\overline{3}$ & ns & 3 & rex & 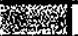 & 3 & & & & & & & \\
\hline Parque, área verde & 2 & 2 & 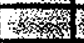 &  & 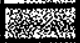 & 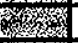 & 2 & & & & & & & \\
\hline Parq/escola (infantil) & 3 & & 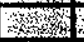 & 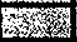 & 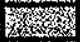 & 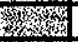 & & & & & & & & \\
\hline Area de laz e desp & 2 & & rescis & 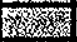 & 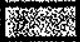 & 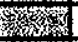 & & & & & & & & \\
\hline Cemitérios & 1 & 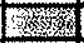 & 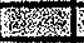 &  & S & (3) & & & & & & & & \\
\hline Escola & 2 & & W & 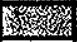 &  & 5 & & & & & & & & \\
\hline Hortas & 3 & & y & & Sy &  & & & & & & & & \\
\hline Área de pecuárla & 1 & 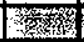 & 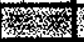 & 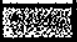 &  & & & & & & & & & \\
\hline Area agrícola & 3 & 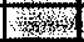 & 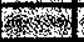 & S & 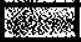 & & & & & & & & & \\
\hline Mata natural & 1 & 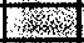 & 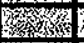 & 2 & S6 & 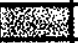 & 1 & & & & & & & \\
\hline APAs & 2 & ris &  & 2xis &  & 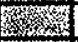 & 2 & & & & & & & \\
\hline APMs & 2 & (1) & 2 & 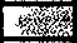 & 2 & b &  & & & & & & & \\
\hline Bac hidr de Abastec & 3 & Dr. & & W & & X- & 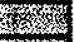 & & & & & & & \\
\hline Aquiferos Import. & 2 & 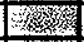 & 2 & S & 2 & 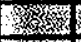 & 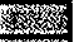 & & & & & & & \\
\hline Zon.maior rest man & 3 & rick & & river & & 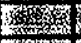 & 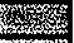 & & & & & & & \\
\hline Area inund, várzea & 2 & 25is & 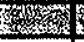 & 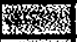 & & 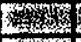 & 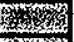 & & & & & & & \\
\hline Repr abastec.público & 3 & W.x. & & 4 & & 4 & 23 & & & & & & & \\
\hline Á sup. Abast público & 3 & Wh & & R & & 전 &  & & & & & & & \\
\hline Poco abast público & 3 & 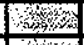 & &  & & 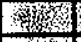 & - & & & & & & & \\
\hline Poço abast domic & 3 & 1, 整 & 3 & S & 3 & W & 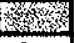 & & & & & & & \\
\hline & & 3 & 3 & 3 & 3 & - & 3 & (x) $2,22=$ & 6,66 & 6,66 & 6,66 & 6,66 & - & 6.66 \\
\hline Critério Princial 3 - I & 32 & teg & $r(D e$ & rods & res & & & & 6,66 & 6,66 & 6,66 & 6,66 & - & 6,66 \\
\hline
\end{tabular}




\section{CRITÉRIO PRINCIPAL 3B - BENS A PROTEGER}

\begin{tabular}{|c|c|c|c|c|c|c|c|c|c|c|c|c|c|c|}
\hline FORADA AREA & $\mathrm{Rn}$ & BP1 & $\mathrm{BP2}$ & BP3 & $\overline{B P 4}$ & BPS & BP6 & $\mathrm{Mn}$ & $\mathrm{BP1}$ & BP2 & $\mathrm{BP} 3$ & $\mathrm{BP} 4$ & BP5 & $\mathrm{BP6}$ \\
\hline Zona ferroviária & 1 & की &  & 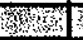 & B & 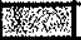 & & & & & & & & \\
\hline Zona viária & 1 & 躍 & Wres & 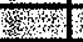 & 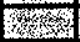 &  & & & & & & & & \\
\hline Estacionemento & 1 & कात्य & 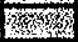 & (4) & 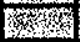 & 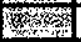 & & & & & & & & \\
\hline Aeroporto & 1 & (1) & 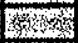 & S & tris & 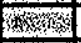 & & & & & & & & \\
\hline Area militar & 1 & mas &  & 泳㳔 & 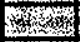 & 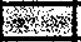 & & & & & & & & \\
\hline Comercial & 1 & , & 362 & 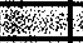 & 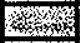 & W & & & & & & & & \\
\hline Industrial & 1 & , & 2. & 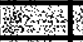 &  & 36 & & & & & & & & \\
\hline Area de interes públ & 1 & ; & 丝 & 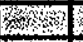 & 2 & X & & & & & & & & \\
\hline Mineraç̆a & 1 & 3 & 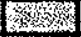 & 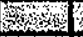 & 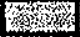 & 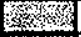 & & & & & & & & \\
\hline Res. Hortas (alt.pop) & 3 & & $y^{0}$ & &  & 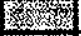 & & & & & & & & \\
\hline Res hortas (bai. poo) & 3 & & s? & & or & 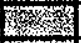 & & & & & & & & \\
\hline Res (atta dens. pop.) & 3 & 3 & s & 3 & . Sor & S & 3 & & & & & & & \\
\hline Res. (bai dens. pop.) & 3 & & S & & 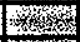 & S & & & & & & & & \\
\hline Parque, área verde & 2 & & X &  &  & s & & & & & & & & \\
\hline Parq/escola (infantil) & 3 & & 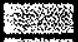 & 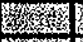 &  & 25e & & & & & & & & \\
\hline Area de laz e desp & 2 & & 20 & 4 & S3ris & 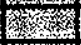 & & & & & & & & \\
\hline Cemitérios & 1 & Wris & 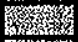 & a & S & 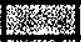 & & & & & & & & \\
\hline Escola & 2 & & 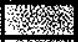 & 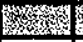 & 2 &  & & & & & & & & \\
\hline Hortes & 3 & & 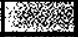 & & 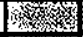 & 1) & & & & & & & & \\
\hline Area de pecuária & 1 &  & (2) & 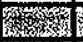 &  & & & & & & & & & \\
\hline Area egrícola & 3 & 3. & 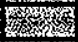 & St & 经 & & & & & & & & & \\
\hline Mata natural & 1 & 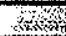 & Wy &  & X & 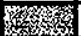 & 3 & & & & & & & \\
\hline APAs & 2 & 20 & 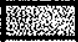 & 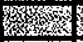 &  & 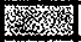 & & & & & & & & \\
\hline APMs & 2 & (5) & 2 & 23 & 2 & 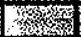 & 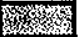 & & & & & & & \\
\hline Bac hidr de Abastec & 3 &  & 3 & W & 3 & 3rox & XX & & & & & & & \\
\hline Aquíferos import. & 2 & 7 & 2 & W & 2 & 20 &  & & & & & & & \\
\hline Zon.maior rest man & 3 & S & & 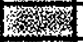 & & Y & S & & & & & & & \\
\hline Area inund, várzea & 2 & 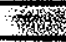 & 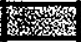 & 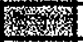 & 2 & 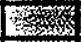 & 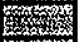 & & & & & & & \\
\hline Repr abastec.público & 3 & w & 3 & 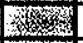 & 3 & W & 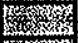 & & & & & & & \\
\hline A sup. Abast público & 3 & W & 3 & W & 3 & 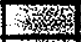 & 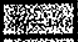 & & & & & & & \\
\hline Poco abast público & 3 & w & & 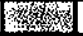 & & 3) & ry & & & & & & & \\
\hline Poco abast domic & 3 & 证 & 3 & Writ & 3 & 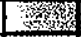 & 1920 & & & & & & & \\
\hline & & 3 & 3 & $\mathbf{3}$ & 3 & $=$ & 3 & (x) $1,11=$ & 3,33 & 3,33 & $\mathbf{3 , 3 3}$ & $\mathbf{3 , 3 3}$ & - & 3,33 \\
\hline \multicolumn{8}{|c|}{ Criterio Princial 3 - Bens a Proteger (Fora da Área) } & & $\mathbf{3 , 3 3}$ & 3,33 & $3, \mathbf{3 3}$ & 3,33 & - & $\mathbf{3 , 3 3}$ \\
\hline \multicolumn{8}{|c|}{ Soma do Critério Principal 3} & & 9,99 & 9,99 & 9,99 & 9,99 & - & 9,99 \\
\hline
\end{tabular}


SOMA DO CRITÉRIO PRINCIPAL 2

\begin{tabular}{|c|c|c|c|c|c|c|c|}
\hline & & BP1 & BP2 & BP3 & $\mathrm{BP4}$ & $\overline{\mathrm{BP5}}$ & BP6 \\
\hline Propagação Via Solo & & 6,6 & 2,8 & 7,0 & 2,8 & 7,0 & 5,8 \\
\hline Propagação Via Água Superficial & + & 3,0 & 3,0 & 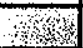 & $\mathbf{3 , 0}$ & 2,0 & 3,0 \\
\hline Propagação Via Água Subterrânea & + & 1,2 & 5,2 & 1,2 & $\mathbf{5 , 2}$ & 0,0 & 1,0 \\
\hline Critério Principal 2 - Propag Via Ar & + & 3,5 & 4. & 1,4 & Hons & 1,4 & $\mathbf{3 , 5}$ \\
\hline & $=$ & 14,3 & 11,0 & 9,6 & 11,0 & 10,4 & 13,3 \\
\hline & $:$ & 1,89 & 1,56 & 1,23 & 1,56 & 1,62 & 1,86 \\
\hline Soma do Critério Principal 2 & & 7,57 & 7,05 & 7,80 & 7,05 & 6,42 & 7,15 \\
\hline
\end{tabular}

\begin{tabular}{|c|c|c|c|c|c|c|c|}
\hline \multicolumn{8}{|c|}{ S } \\
\hline & & BP1 & BP2 & BP3 & BP4 & BP5 & BP6 \\
\hline \multirow[t]{2}{*}{ Soma do Critério Principal 1} & & 9,04 & 9,04 & 9,04 & 9,04 & 9,04 & 9,04 \\
\hline & $\mathbf{x}$ & & & & & & \\
\hline \multirow[t]{2}{*}{ Soma do Critério Principal 2} & & 7,57 & 7,05 & 7,80 & 7,05 & 6,42 & 7,15 \\
\hline & $x$ & & & & & & \\
\hline \multirow[t]{2}{*}{ Soma do Critério Principal 3} & & 9,99 & 9,99 & $\overline{-}$ & 9,99 & 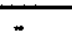 & 9,99 \\
\hline & $=$ & & & & & & \\
\hline Pontuação Final & & 684 & 637 & 704 & 637 & 58 & 646 \\
\hline
\end{tabular}




\section{ANEXO 2 PONTUAÇÕES OBTIDAS PELAS ÁREAS DE DISPOSIÇÃO DE RESÍDUOS DA RMSP}




\begin{tabular}{|c|c|c|c|c|c|c|c|c|}
\hline Número & Aterro & Municipio & BP1 & $B P 2$ & $B P 3$ & $B P 4$ & $B P 5$ & $B P 6$ \\
\hline 1 & Ant L Munic & Arujá & 303 & 42 & 52 & 34 & 53 & 365 \\
\hline 2 & L Motel Bah & Barueri & 79 & 37 & 44 & 38 & 38 & 90 \\
\hline 3 & L Barueri & Barueri & 152 & 44 & 52 & 46 & 52 & 170 \\
\hline 4 & Ant LEstr $S$ & Biritiba Mirim & 12 & 102 & 26 & 121 & 21 & 25 \\
\hline 5 & Inibra & Caieiras & & & & & & \\
\hline 6 & L Mun Caiei & Caieiras & 212 & 28 & 37 & 31 & 31 & 226 \\
\hline 7 & LPort Laranj & Caieiras & 85 & 97 & 32 & 103 & 24 & 94 \\
\hline 8 & Vi.dos Pinhe & Caieiras & 73 & 21 & 27 & 22 & 23 & 91 \\
\hline 9 & L Municipal & Cajamar & & & & & & \\
\hline 10 & L Carapicuib & Carapicuiba & 143 & 44 & 181 & 47 & 47 & 169 \\
\hline 11 & Aterro Sanita & Cotia & 225 & 36 & 46 & $\overline{34}$ & 40 & 255 \\
\hline 12 & Antigo L Diad & Diadema & 107 & 38 & 37 & 38 & 37 & 121 \\
\hline 13 & A. Tensăo & E. Guaçu & 110 & 225 & 39 & 34 & 198 & 108 \\
\hline 14 & B. do Paca & E. Guacu & 169 & 108 & 130 & 108 & 30 & 104 \\
\hline 15 & Bei da Estra & E. Guaçu & 87 & 69 & 36 & 72 & 27 & 27 \\
\hline 16 & E. do Bayton & E. Guaçu & 91 & 66 & 36 & 69 & 27 & 93 \\
\hline 17 & L. da Cobra & E. Guaçu & 71 & 29 & 29 & 30 & 22 & 74 \\
\hline 18 & L Desativado & Embú & 84 & 230 & 32 & 230 & 24 & 101 \\
\hline 19 & L. Mun Embú & Embú & 282 & 128 & 44 & 128 & 37 & 323 \\
\hline 20 & Lix F. Rocha & F. Rocha & 90 & 29 & 37 & 31 & 37 & 111 \\
\hline 21 & M. Lixăol & F. Rocha & 21 & 29 & 27 & 31 & 24 & 57 \\
\hline 22 & M. Lixăo II & F. Rocha & 21 & 29 & 27 & 31 & 24 & 57 \\
\hline 23 & Antigo L Fco & Fco Morato & 55 & 26 & 31 & 28 & 27 & 86 \\
\hline 24 & $L$ Mun Fco M & Fco Morato & 77 & 29 & 37 & 30 & 32 & 109 \\
\hline 25 & L Ferraz Vas & Ferraz Vasc & 25 & 149 & 42 & 153 & 34 & 30 \\
\hline 26 & L Mun(mimi) & Franco Roch & 27 & 35 & 43 & 32 & 38 & 41 \\
\hline 27 & Antigo L VI. & Guararema & 73 & 26 & 85 & 29 & 45 & 131 \\
\hline 28 & CIPAS Biritib & Guararema & 87 & 34 & 105 & 34 & 30 & 74 \\
\hline 29 & Lixåo Guarar & Guararema & 13 & 62 & 36 & 69 & 23 & 83 \\
\hline 30 & Ant L Itapegi & Guarulhos & 193 & 35 & 34 & 38 & 31 & 255 \\
\hline 31 & Jd Arapong 1 & Guarulhos & 375 & 34 & 32 & 35 & 29 & 437 \\
\hline 32 & Jd Arapong 2 & Guarulhos & 204 & 39 & 37 & 41 & 36 & 237 \\
\hline 33 & L Aguazul & Guarulhos & 249 & 38 & 53 & 42 & 41 & 291 \\
\hline 34 & L. Bonsucess & Guarulhos & 117 & 34 & 143 & 37 & 132 & 138 \\
\hline 35 & LPq CECAP & Guarulhos & 108 & 33 & 39 & 68 & 32 & 110 \\
\hline 36 & Pq Ecol Tiête & Guarulhos & 124 & 33 & 46 & 36 & 40 & 145 \\
\hline 37 & Ant L Itape 1 & Itapecerica & 168 & 32 & 36 & 33 & 27 & 170 \\
\hline 38 & Ant L Itape 2 & Itapecerica & 197 & 31 & 29 & 33 & 176 & 189 \\
\hline 39 & Ant $L$ Jd $S M$ & Itapecerica & 134 & 26 & 30 & 28 & 27 & 193 \\
\hline 40 & LMun Itapec & Itapecerica & 187 & 162 & 43 & 162 & 216 & 243 \\
\hline 41 & L desativado & Itapevi & 24 & 84 & 42 & 88 & 37 & 36 \\
\hline 42 & L Itap Cohab & Itapevi & 132 & 41 & 52 & 43 & 118 & 151 \\
\hline 43 & L Itapevi & Itapevi & 95 & 30 & 37 & 37 & 32 & 115 \\
\hline 44 & CIPAS & Itaquaquec & 81 & 32 & 41 & 34 & 35 & 119 \\
\hline 45 & Farabolini & Itaquaquec & 114 & 94 & 44 & 101 & 39 & 142 \\
\hline 46 & L Ter Rocha & Itaquaquec & 307 & 32 & 32 & 32 & 28 & 360 \\
\hline 47 & L Bair Vitalin & Juquitiba & 77 & 27 & 33 & 29 & 90 & 89 \\
\hline 48 & Lixão Munic & Juquitiba & 67 & 170 & 28 & 170 & 25 & 76 \\
\hline 49 & Ant L Munic & Mairiporă & 23 & 28 & 30 & 28 & 30 & 35 \\
\hline 50 & Al Boa Hora & Mauá & 28 & 250 & 36 & 168 & 33 & 39 \\
\hline 51 & L Mauá (San) & Mauá & 25 & 34 & 31 & 36 & 29 & 30 \\
\hline
\end{tabular}




\begin{tabular}{|c|c|c|c|c|c|c|c|c|}
\hline 52 & Lara/Sertåoz & Mauá & 80 & 198 & 36 & 209 & 214 & 386 \\
\hline 53 & Rod Hobbes & Mauá & 36 & 44 & 49 & 46 & 42 & 48 \\
\hline 54 & Sapope VI & Mauá & 143 & 41 & 53 & 43 & 46 & 153 \\
\hline 55 & Ater de Mogi & Mogi Cruzes & 160 & 60 & 30 & 63 & 27 & 185 \\
\hline 56 & L Bair Rodeio & Mogi Cruzes & 23 & 174 & 30 & 181 & 27 & 27 \\
\hline 57 & LFco Filhol & Mogi Cruzes & 104 & 154 & 42 & 168 & 37 & 128 \\
\hline 58 & LFco Filho II & Mogi Cruzes & 34 & 182 & 45 & 191 & 42 & 40 \\
\hline 59 & L Taiaçupeba & Mogi Cruzes & 20 & 185 & 24 & 194 & 24 & 26 \\
\hline 60 & Volta Fria I & Mogi Cruzes & 207 & 154 & 39 & 161 & 30 & 210 \\
\hline 61 & Volta Fria II & Mogi Cruzes & 203 & 140 & 38 & 151 & 84 & 319 \\
\hline 62 & Volta Fria III & Mogi Cruzes & 287 & 299 & 65 & 312 & 144 & 421 \\
\hline 63 & Ater Sanitár & Osasco & 121 & 44 & 184 & 46 & 48 & 174 \\
\hline 64 & L Água Verm & Poá & 214 & 81 & 44 & 88 & 39 & 316 \\
\hline 65 & L VI Varela & Poá & 116 & 192 & 49 & 201 & 46 & 159 \\
\hline 66 & Ant L Rib Pir & Ribeir Pires & 294 & 43 & 47 & 44 & 40 & 372 \\
\hline 67 & A Matar-BHC & S. Andre & 342 & 38 & 45 & 39 & 40 & 437 \\
\hline 68 & ALMS Andre & S. Andre & 413 & 44 & 52 & 46 & 45 & 490 \\
\hline 69 & AM S Andre & S. Andre & 121 & 47 & 54 & 49 & 47 & 165 \\
\hline 70 & Bandeirantes & S. B. Campo & 287 & 45 & 54 & 47 & 47 & 337 \\
\hline 71 & Cama Patent & S. B. Campo & 276 & 360 & 52 & 375 & 45 & 327 \\
\hline 72 & Cooperat I & S. B. Campo & 138 & 44 & 52 & 41 & 45 & 163 \\
\hline 73 & Cooperat II & S. B. Campo & & & & & & \\
\hline 74 & Montanháo & S. B. Campo & 60 & 41 & 23 & 43 & 20 & 119 \\
\hline 75 & T de Guerra & S. B. Campo & 133 & 31 & 204 & 32 & 28 & 200 \\
\hline 76 & A.S.Sapope & S. Paulo & 148 & 44 & 55 & 47 & 52 & 183 \\
\hline 77 & At. Jacuí & S. Paulo & 203 & 37 & 38 & 37 & 32 & 286 \\
\hline 78 & Barrocada & S. Paulo & 97 & 31 & 99 & 31 & 29 & 111 \\
\hline 79 & Cebolão & S. Paulo & 112 & 35 & 37 & 80 & 36 & 99 \\
\hline 80 & E Pessegol & S. Paulo & 35 & 33 & 44 & 37 & 334 & 419 \\
\hline 81 & E Pessego II & S. Paulo & 35 & 33 & 44 & 37 & 334 & 419 \\
\hline 82 & Est Palanque & S. Paulo & 304 & 39 & 52 & 40 & 45 & 324 \\
\hline 83 & Guarulhos VI & S. Paulo & 183 & 30 & 32 & 31 & 25 & 189 \\
\hline 84 & Jd. S. Joăo & S. Paulo & 298 & 31 & 392 & 72 & 37 & 350 \\
\hline 85 & Lauzane & S. Paulo & 158 & 71 & 67 & 75 & 61 & 177 \\
\hline 86 & Lix Itaquera & S. Paulo & 157 & 30 & 29 & 125 & 28 & 205 \\
\hline 87 & Ped ltaberaba & S. Paulo & 195 & 213 & 231 & 223 & 205 & 202 \\
\hline 88 & Ped ltatinga & S. Paulo & 84 & 189 & 39 & 189 & 37 & 109 \\
\hline 89 & Pq. R. Tavar & S. Paulo & 234 & 31 & 28 & 31 & 29 & 297 \\
\hline 90 & Quitaúna & S. Paulo & 115 & 32 & 134 & 35 & 36 & 124 \\
\hline 91 & Såo Joåo & S. Paulo & 95 & 30 & 42 & 71 & 91 & 119 \\
\hline 92 & Săo Mateus & S. Paulo & 59 & 37 & 38 & 37 & 37 & 83 \\
\hline 93 & Sapope I & S. Paulo & 228 & 41 & 46 & 43 & 36 & 275 \\
\hline 94 & Sapope II & S. Paulo & 167 & 31 & 34 & 32 & 30 & 202 \\
\hline 95 & Sapope III & S. Paulo & 198 & 30 & 35 & 31 & 31 & 233 \\
\hline 96 & Sapope IV & S. Paulo & 508 & 64 & 63 & 67 & 71 & 589 \\
\hline 97 & Sapope V & S. Paulo & 237 & 64 & 46 & 43 & 41 & 309 \\
\hline 98 & Sapope VII & S. Paulo & 119 & 37 & 41 & 39 & 36 & 142 \\
\hline 99 & Sapope VIII & S. Paulo & 53 & 19 & 22 & 20 & 19 & 64 \\
\hline 100 & Sto Amaro & S. Paulo & 78 & 301 & 37 & 301 & 36 & 82 \\
\hline 101 & V Albertina & S. Paulo & 216 & 160 & 241 & 178 & 87 & 225 \\
\hline 102 & V. Curuça & S. Paulo & 132 & 19 & 17 & 178 & 16 & 179 \\
\hline 103 & L Matadouro & Salesopolis & 204 & 103 & 32 & 107 & 24 & 208 \\
\hline
\end{tabular}




\begin{tabular}{|c|l|c|c|c|c|c|c|c|}
\hline 104 & L Morro Gde & Sta.Isabel & 86 & 30 & 30 & 31 & 29 & 98 \\
\hline 105 & L Mun Sta.Is & Sta.Isabel & 39 & 94 & 53 & 98 & 132 & 132 \\
\hline 106 & L Antig Suza & Suzano & 134 & 40 & 147 & 42 & 43 & 51 \\
\hline 107 & L Desat Tab & Taboão Serra & 84 & 30 & 27 & 30 & 27 & 93 \\
\hline 108 & L Estr Lages & Var Gde Pta & 16 & 21 & 25 & 22 & 75 & 57 \\
\hline 109 & L Ferreira Gu & Var Gde Pta & 80 & 31 & 33 & 33 & 103 & 195 \\
\hline 110 & L Rua Pales & Var Gde Pta & 307 & 33 & 113 & 34 & 26 & 326 \\
\hline 111 & L Barrocada & Guarulhos & 102 & 167 & 140 & 180 & 0 & 116 \\
\hline 112 & L Mun Cajam & Cajamar & 31 & 38 & 47 & 39 & 41 & 45 \\
\hline 113 & L Alvarenga & Diadema & 684 & 637 & 704 & 637 & 58 & 646 \\
\hline 114 & Aterro Cipas B.M & Biritiba Mirim & 172 & 118 & 168 & 136 & 162 & 147 \\
\hline 115 & L. Estr. Sta Cat. & Biritiba Minirm & 0 & 267 & 0 & 171 & 104 & 78 \\
\hline 116 & Lix. Munic & Mairiporã & 0 & 108 & 0 & 161 & 134 & 103 \\
\hline
\end{tabular}

